\title{
USO DE JOGOS DIGITAIS NO DESENVOLVIMENTO DE COMPETÊNCIAS CURRICULARES DA MATEMÁTICA
}

\author{
Adalberto Bosco Castro Pereira \\ TESE APRESENTADA \\ $\mathrm{AO}$ \\ Instituto De Matemática E EstatísticA \\ DA \\ Universidade DE SÃo PAUlo \\ PARA \\ OBTENÇÃO DO TÍTULO \\ $\mathrm{DE}$ \\ DOUTOR EM CIÊNCIAS \\ Programa: Ciências da Computação \\ Orientador: Prof. Dr. Flávio Soares Correa da Silva
}

Durante o desenvolvimento deste trabalho o autor recebeu auxílio financeiro da CAPES

São Paulo, Agosto de 2017 


\section{USO DE JOGOS DIGITAIS NO DESENVOLVIMENTO DE COMPETÊNCIAS CURRICULARES DA MATEMÁTICA}

Esta é a versão original da tese elaborada pelo candidato Adalberto Bosco Castro Pereira, tal como submetida à Comissão Julgadora. 


\section{Agradecimentos}

A realização desta tese contou com o apoio e o incentivo de colegas, familiares e amigos que estiveram sempre presentes, bem como com o fomento da CAPES.

Agradeço ao professor orientador Flávio Soares Correa da Silva, pela sua postura acadêmica, que acreditou na escolha da pesquisa-ação como estruturante fundamental de imersão permanente no contexto escolar, sempre presente e disposto a dialogar sobre possibilidades e dificuldades.

À professora Stela C. Bertholo Piconez, pilar fundamental no desenvolvimento deste projeto, com dedicação e colaboração imprescindíveis, provendo lapidação e refinamento para esta tese. Assumiu o papel de co-orientadora deste trabalho, com autorização do professor orientador oficial, Flávio, por possuir profundo conhecimento relacionado à educação, pedagogia, uso de tecnologias na formação docente e afins. Em conjunto com o professor Flávio Soares Correa da Silva, agradeço pela enorme dedicação e colaboração da professora Stela, sempre presente e prestativa, o que permitiu articular o tema "Games com o Currículo Escolar de Matemática do Ensino Fundamental II".

A Josete Maria Zimmer, professora da escola e membro do Grupo Alpha, um agradecimento especial pois, junto à equipe gestora, professores e alunos da Escola Estadual Fernando Nobre, participantes colaborativos e ativos, foram relevantes e sem os quais seria impossível refletir sobre as modificações estruturantes de suas cognições.

Ao Grupo Alpha de Pesquisa, pertencente à Faculdade de Educação - USP (Diretório de Pesquisas do CNPq), e seus participantes, que foram fundamentais para o crescimento pessoal e construção de conhecimento, além dos diálogos e ajudas relacionadas à coleta e à análise de dados presentes nesta tese. Permitiram ao pesquisador o distanciamento necessário para a interpretação da realidade investigada sob os diferentes olhares de suas áreas de conhecimentos interdisciplinares.

Agradeço também aos colegas de turma e laboratório (LIDET e LIAMF) pela ajuda, colaboração e intercâmbio de conhecimentos, seja na tese ou na trajetória percorrida durante todo o doutorado. 


\section{Resumo}

Pereira, A. B. C. USO DE JOGOS DIGITAIS NO DESENVOLVIMENTO DE COMPETÊNCIAS CURRICULARES DA MATEMÁTICA. 2015. Tese - Instituto de Matemática e Estatística, Universidade de São Paulo, São Paulo, 2017.

Este doutorado investigou as contribuições dos jogos digitais no desenvolvimento de conhecimentos matemáticos previstos nas competências curriculares em uma escola estadual de tempo integral, situada em Cotia - São Paulo. As análises realizadas foram fundamentadas a partir das categorias estudadas pelo psicólogo e educador Reuven Feuerstein quanto às mudanças na estrutura cognitiva (EAM) de alunos do Ensino Fundamental II. Esta investigação foi desenvolvida com 60 alunos e três professoras de Matemática em Oficinas Curriculares denominadas Experiências Matemáticas. Sua trajetória metodológica contou com a participação da equipe gestora, professores de Matemática, alunos do Ensino Fundamental II e Grupo Alpha de Pesquisa - FEUSP durante dois anos. A investigação, de natureza qualitativa, caracterizou-se como pesquisa-ação e contou com a imersão total do pesquisador no campo amostral. Foram adotados técnicas e procedimento de pesquisa triangulados como a observação participante, entrevistas semiestruturadas, entrevistas informais, grupos focais, gravação de áudio e vídeos, fotos, diários de campo, atividades com os jogos digitais, um ambiente virtual (Moodle) e a combinação de duas redes sociais, FaceBook e WhatsApp. Os resultados apontaram que: i) o contexto escolar representa espaço privilegiado de sistematização e compreensão do complexo registro notacional da Matemática com a mediação dos jogos digitais; ii) o ensino da Matemática por meio de jogos digitais conferem sentido e significado às aprendizagens dos alunos; iii) os jogos digitais conferem ao desenvolvimento de competências e habilidades cognitivas com flexibilidade, autonomia, transcendência e construção de significados que são alguns critérios de mediação apontados por Feuerstein; iv) os jogos digitais favorecem a compreensão de conteúdos matemáticos de forma colaborativa e lúdica; v) os professores de Matemática necessitam de formação permanente que possa ampliar as transformações pedagógicas inovadoras de novos modos de aprender e de ensinar; vi) as abordagens pedagógicas podem se beneficiar de perspectivas contemporâneas como mobile-learning, Flipped-classroom e Bring Your Own Device como formas de reduzir os desafios e dificuldades das escolas públicas (políticas educacionais, infraestrutura, formação docente).

Palavras-chave: Ensino Fundamental II, Jogos Digitais, Mobile Learning, Matemática. 


\section{Abstract}

Pereira, A. B. C. USE OF DIGITAL GAMES TO DEVELOP MATHEMATICAL CURRICULAR COMPETENCIES. 2015. Thesis - Institute of Mathematics and Statistics, University of São Paulo, São Paulo, 2017.

This thesis investigated the contributions of digital games in the development of mathematical knowledge foreseen in curricular competencies in a full-time state school located in Cotia - São Paulo. The analysis was based on the categories studied by the psychologist and educator Reuven Feuerstein regarding the Structural Cognitive Modifiability (SCM) of K-12 school. This research was developed with 60 students and three teachers of Mathematics in Curricular Workshops denominated Mathematical Experiences. The methodological approach has included with the participation of the management team, teachers of Mathematics, K-12 and Alpha Research Group of FE-USP for two years. The research approach was qualitative using action research in which the researcher was totally immersed in the field. Procedures and techniques were adopted in order to ensure triangulation with the observation of participants, semi-structured interviews, formal interviews, focus groups, recording of audio and video, photos, field diaries, digital games activities, a virtual learning environment (Moodle) and the combination of two social networks: FaceBook and WhatsApp. The results indicated that: i) the school context represented a privileged space for systematization and comprehension of the complex Notational register of Mathematics with the mediation of digital games; ii) teaching of mathematics through digital games resulting in a meaningful learning process to students; iii) Digital games enabled the development of cognitive skills and abilities with flexibility, autonomy, transcendence, and meaning, which are some mediation criteria pointed out by Feuerstein; iv) digital games facilitated the understanding of mathematical content in a collaborative and playful way; v) Teachers needed ongoing training that can enhance the innovative pedagogical transformations of new ways of learning and teaching; vi) Teaching approaches can benefit from contemporary perspectives such as mobile-learning, Flipped-classroom and Bring Your Own Device, the ways of reducing the challenges and difficulties of public schools(educational policies, infrastructure, and teacher training).

Key-words: K-12, Digital Games, Mobile Learning, Mathematics. 


\section{Sumário}

Lista de Abreviaturas $\quad$ xi

Lista de Figuras $\quad$ xiii

Apresentação $\quad$ xv

Introdução $\quad$ xvii

1 Jogos Digitais e aprendizagem de Matemática $\quad 1$

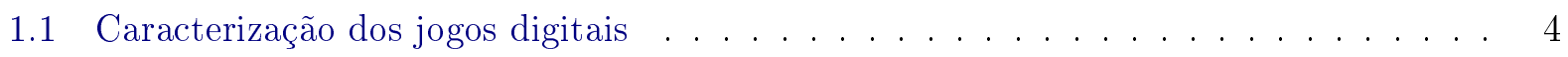

1.2 Características dos jogos e suas relações com a Matemática . . . . . . . . . . . 9

2 Trajetória Metodológica $\quad 15$

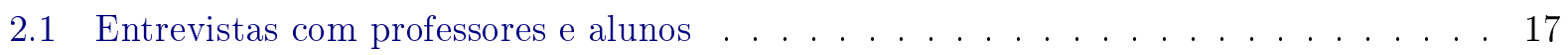

2.2 Avaliação com Grupos Focais . . . . . . . . . . . . . . . . . . 17

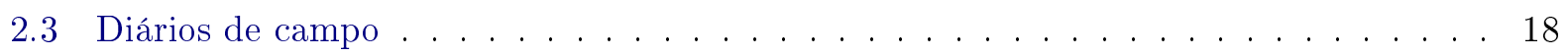

2.4 Triangulação de dados . . . . . . . . . . . . . . . . . . . . 18

2.5 Caracterização da Cidade e da Escola e dos Participantes . . . . . . . . . . . . . 19

2.6 Estrutura da investigação . . . . . . . . . . . . . . . . . 28

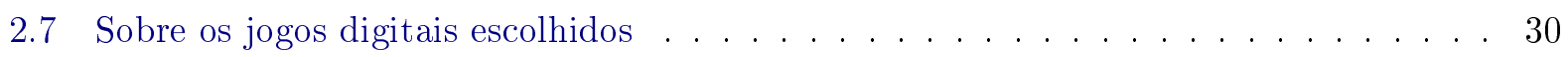

3 Revisão da Literatura $\quad 33$

3.1 Produção nacional . . . . . . . . . . . . . . . . . . . . . . . . 33

3.2 Produção internacional . . . . . . . . . . . . . . . . . . . . 41

4 Horizonte Teórico Interpretativo $\quad 47$

4.1 Modificabilidade Cognitiva Estrutural (MCE) . . . . . . . . . . . . . . . . . 48

4.2 Experiência de Aprendizagem Mediada (EAM) . . . . . . . . . . . . . . . 49

4.3 Competências da EAM . . . . . . . . . . . . . . . . 51

5 Contribuições dos Jogos Digitais e Competências Curriculares da Matemática 55

5.1 Relação dos jogos digitais escolhidos com a Matemática . . . . . . . . . . . . . 72

5.2 Moodle com os professores . . . . . . . . . . . . . . . . . 79

5.3 Análise dos resultados da mediação . . . . . . . . . . . . . . . . . . . 79

6 Considerações Finais $\quad 83$ 
Apêndices

A Termo de Consentimento Livre e Esclarecido

B Termo de Consentimento do Diretor da Escola Fernando Nobre

C Sondagem Diagnóstica - Alunos

D Sondagem Diagnóstica Estudantes e uso das TDIC

E Uso De Jogos Digitais Na Oficina De Experiências Matemáticas

F Questionário de Sondagem Diagnóstica dos Professores

G Moodle

H Moodle-Forum

I Planejamento Da Oficina Experiências Matemáticas Com Uso De Jogos Digitais106

J Fotos Da Escola Fernando Nobre

L Grupo Focal-Transcrição

A Projeto De Tecnologias Digitais De Informação E Comunicação

B Planejamento Da Oficina Experiências Matemáticas Da Professora Roseli

C Grupo Aberto no Facebook

D Redes Sociais -Whatsapp

E Moodle - Grupo Alpha

F Matriz Curricular 


\section{Lista de Abreviaturas}

BYOD Traga Seu Próprio Dispositivo (Bring Your Own Device)

ML Aprendizagem Móvel (Mobile Learning)

EAM Experiência De Aprendizagem Mediada (Mediated Learning Experience)

MCE Modificabilidade Cognitiva Estrutural (Structural Cognitive Modifiability)

RTS Estratégia em Tempo Real (Real-Time Strategy)

RPG Jogo de Representação (Role-playing game)

MMO Multi Massivo Online (Massively Multiplayer Online)

MOBA Arena de Batalha Multiplayer Online (Multiplayer Online Battle Arena)

TIC Tecnologias de Informação e Comunicação (Information and Communications Technology) 


\section{Lista de Figuras}

1.1 Taxonomia Revisitada de Bloom $($ Shrock, 2016) . . . . . . . . . . . . . . . 3

1.2 Exemplo de HUD . . . . . . . . . . . . . . . . . . . . . . 10

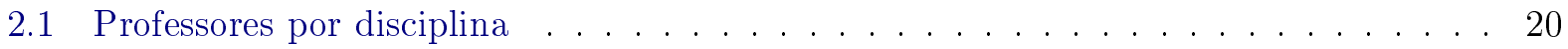

2.2 Faixa Etária dos alunos . . . . . . . . . . . . . . . . . . . . 23

2.3 Tempo de uso do smartphone . . . . . . . . . . . . . . . . . . 23

2.4 Uso de TDIC na visão dos alunos . . . . . . . . . . . . . . . . . . . . . 24

2.5 Funcionamento da Escola de tempo Integral . . . . . . . . . . . . . . . . . 27

2.6 Passos executados nos ciclos desta pesquisa . . . . . . . . . . . . . . 28

4.1 Modelo EAM retirado de (Feuerstein et al., 2014, p. 65) . . . . . . . . . . . 50

4.2 Interação das ZDP . . . . . . . . . . . . . . . . . . . 51

5.1 Mapa conceitual da triangulação de dados . . . . . . . . . . . . . . . . 56

5.2 Visão principal do jogo com o HUD . . . . . . . . . . . . . . . . . . . . 72

5.3 Gráficos do jogo em relação a satisfação populacional . . . . . . . . . . . . . . . . 73

5.4 Barras de progresso de atividades . . . . . . . . . . . . . . . . . . . . 74

5.5 Barras de progresso de atividades . . . . . . . . . . . . . . . 75

5.6 Promoção de um avatar . . . . . . . . . . . . . . . . . . . . . . 75

5.7 Imagens do jogo Clash of clans . . . . . . . . . . . . . . . . 77

5.8 Valquíria e Gigante . . . . . . . . . . . . . . . . . . . . . . . . 77

B.1 Documento digitalizado . . . . . . . . . . . . . . . . . . . . 91

C.1 Documento digitalizado . . . . . . . . . . . . . . . . . . 93

D.1 Documento digitalizado f . . . . . . . . . . . . . . . . . . 95

E.1 Documento digitalizado . . . . . . . . . . . . . . . . . . 97

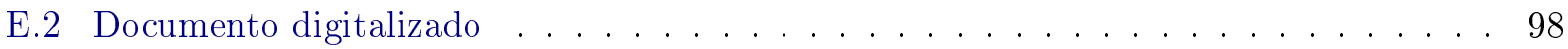

F.1 Documento digitalizado . . . . . . . . . . . . . . . . . . . 100

F.2 Documento digitalizado . . . . . . . . . . . . . . . . . . . . . 101

G.1 Documento digitalizado . . . . . . . . . . . . . . . . . . 103

H.1 Documento digitalizado . . . . . . . . . . . . . . . . . . 105 
I.1 Documento digitalizado . . . . . . . . . . . . . . . . . . . 107

J.1 Documento digitalizado . . . . . . . . . . . . . . . . . . . . 109

K.1 Documento digitalizado . . . . . . . . . . . . . . . . . . . . 111

K.2 Documento digitalizado . . . . . . . . . . . . . . . . . . . . 112

L.1 Documento digitalizado . . . . . . . . . . . . . . . . . . . . 114

L.2 Documento digitalizado . . . . . . . . . . . . . . . . . . 115

L.3 Documento digitalizado . . . . . . . . . . . . . . . . . . . 116

L.4 Documento digitalizado . . . . . . . . . . . . . . . . . . 117

A.1 Documento digitalizado . . . . . . . . . . . . . . . . . . . 120

A.2 Documento digitalizado . . . . . . . . . . . . . . . . . . . . 121

A.3 Documento digitalizado . . . . . . . . . . . . . . . . . . . 122

B.1 Documento digitalizado . . . . . . . . . . . . . . . . . . . . . . 124

B.2 Documento digitalizado . . . . . . . . . . . . . . . . 125

C.1 Documento digitalizado . . . . . . . . . . . . . . . . . . 127

C.2 Documento digitalizado . . . . . . . . . . . . . . . . . 128

D.1 Documento digitalizado . . . . . . . . . . . . . . . . . . . 130

D.2 Documento digitalizado . . . . . . . . . . . . . . . . . 131

D.3 Documento digitalizado . . . . . . . . . . . . . . . . . . . . . . . . . 132

D.4 Documento digitalizado . . . . . . . . . . . . . . . . . . 133

D.5 Documento digitalizado . . . . . . . . . . . . . . . . . . . . 134

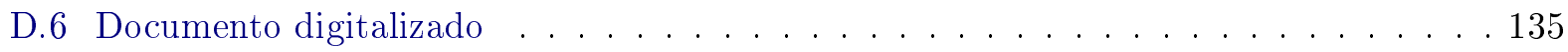

E.1 Documento digitalizado . . . . . . . . . . . . . . . . . 136

E.2 Documento digitalizado . . . . . . . . . . . . . . . . . . . 137

F.1 Documento digitalizado . . . . . . . . . . . . . . . . . . . . 139 


\section{Apresentação}

Esta investigação teve por objetivo verificar as contribuições dos jogos digitais no desenvolvimento das competências matemáticas previstas na legislação educacional. Configurou-se como pesquisa de natureza qualitativa, sob a perspectiva de pesquisa-ação, cuja realidade foi apreendida e analisada segundo as ideias de Feuerstein et al. (2014). O campo de aproximação e conhecimento ocorreu em escola estadual de Ensino Fundamental II, com atuação no componente curricular Matemática de seus $8^{\circ}$ e $9^{\circ}$ anos, em espaço conhecido como Oficinas Experiências Matemáticas. Foi adotada perspectiva Bring your own device (BYOD) e mobile learning, com uso dos telefones celulares dos alunos. Foram agregados às atividades desenvolvidas o apoio de redes sociais como o Facebook e o WhatsApp e também de um ambiente virtual de aprendizagem para professores (Moodle).

Na Introdução são identificados alguns desafios encontrados nos cenários internacional, nacional e local que justificam os objetivos da investigação atribuindo-lhe relevância diante dos avanços da internet. A trajetória profissional e acadêmica do pesquisador foram relevantes e agregaram elementos que favoreceram a análise dos dados. As hipóteses e objetivos foram direcionados para as contribuições que os jogos digitais podem oferecer na interação com o currículo e as atividades de Matemática, no que se refere ao desenvolvimento de competências previstas pela legislação educacional.

No Capítulo 1 Jogos Digitais e aprendizagem de Matemática são descritos os jogos digitais, conceitos e modalidades, tipologia, design de produção e de funcionamento que colocam o foco em suas características e importância como apoio pedagógico no contexto escolar.

No Capítulo 2 Trajetória Metodológica é descrito o contexto escolar da realidade investigada (caracterização da escola, dos participantes da pesquisa, procedimentos de pesquisa), bem como o desenvolvimento do diálogo dos dados coletados com um horizonte teórico interpretativo baseado nas ideias de Feuerstein et al. (2014), que proporcionaram conhecer e compreender as contribuições dos jogos digitais e sua interação com os conteúdos matemáticos e a aprendizagem significativa dos alunos.

No Capítulo 3 Revisão da Literatura as produções acadêmicas descritas foram tratadas metodologicamente segundo alguns indicadores: ano da produção, autor, título, instituição, modalidades de produção (tese/dissertação/artigos e periódicos) e fundamentação teórica utilizada para análise de pesquisas com jogos digitais. Foi dado destaque às produções cujo contexto envolveram a Educação Básica.

O Capítulo 4 Horizonte Teórico Interpretativo descreve os estruturantes da Teoria da Modificabilidade Cognitiva Estrutural de Feuerstein et al. (2014), que auxiliaram no diálogo com os dados coletados na realidade investigada. Descreve ainda os elementos constituintes da teoria de Experiência de Aprendizagem Mediada (EAM) também estudada por Feuerstein et al. (2014). 
O Capítulo 5 Contribuições dos Jogos Digitais e Competências Curriculares da Matemática apresenta o diálogo estabelecido do desenvolvimento das habilidades matemáticas de alunos do ensino fundamental II e as contribuições e desafios envolvidos em estratégias metodológicas próprias desta investigação e da vivência de jogos digitais inseridos em atividades escolares. Tal diálogo teve como horizonte teórico interpretativo as categorias de análises inspiradas pelas ideias de Feuerstein et al. (2014) com a finalidade de atribuir sentido e significado aos objetivos previstos. Nesse capítulo, são identificados os desafios que os jogos digitais apresentam na interação com o currículo de Matemática incluindo as contribuições metodológicas importantes para a adoção pelas escolas e para formação docente.

Finalmente, no capítulo 6, Considerações Finais são apontadas: i) as contribuições dos jogos digitais para a aprendizagem significativa dos alunos nas diferentes frentes da Matemática trabalhadas nas escolas; ii) as atividades colaborativas relevantes para inclusão escolar; iii) algumas alternativas inovadoras para avaliação escolar e, iv) são sugeridas transformações no sentido da formação docente em serviço ou de forma permanente. A natureza multi e interdisciplinar de desenvolvimento de pesquisas foi destacada como relevante contribuição, tendo na imersão ao contexto escolar, novas oportunidades de compreensão de metodologia de pesquisa científica que se aproxima da realidade investigada.

O texto é complementado com Referências, Apêndices e Anexos. 


\section{Introdução}

Há algum tempo o mundo vem presenciando rápidas e sucessivas mudanças tecnológicas e culturais que têm ampliado possibilidades de acesso à informação, comunicação e produção de conhecimentos de forma coletiva. A escola não pode deixar de acompanhar tais mudanças e buscar novas estratégias pedagógicas que possibilitem acompanhar, de forma mais situada, a contemporaneidade vivida pelos alunos. Reflexões e estudos podem reverter o quadro dos atuais índices de desempenho dos alunos em Matemática, apontado pelas avaliações realizadas em grande escala e que denotam a urgente necessidade de melhoria. Um dos estruturantes didáticos passa pela seleção de metodologias de ensino e de aprendizagem que nem sempre têm sido adotados e pensados pelos professores em termos de atualização diante da exuberância de recursos tecnológicos que já constituem parte do universo dos alunos e que incluem os jogos digitais.

A humanidade vem presenciando uma revolução tecnológica, especialmente desde meados dos anos 1980, com as tecnologias digitais. Tal movimento tecnológico criou um ambiente propício para o surgimento de aplicações tecnológicas voltadas para atividades socioculturais e de entretenimento. Segundo Castells (1999), as transformações sociais, políticas e econômicas iniciadas ao longo do século XX, e que ainda estão acontecendo na sociedade contemporânea, foram potencializadas pelas Novas Tecnologias de Informação e Comunicação, nas quais se inclui a computação, a internet e os jogos digitais (Lourenço, 2012).

Essas mudanças são posicionadas dentro de processos amplos de globalização, interligando o mundo, difundindo características econômicas, sociais, políticas e culturais de cada lugar do mundo, possibilitando o surgimento de uma "Aldeia Global" (Lourenço, 2012).

Evidências arqueológicas mostram que diversas culturas e organizações sociais já faziam uso de jogos (Vieira e Corrêa da Silva, 2014). Os egípcios, conforme indicam pinturas em paredes de 3.000 A.C., usavam jogos de tabuleiros (Piccione, 1980). Há também o jogo Shaturanga, precursor do xadrez, criado e utilizado na Índia e Pérsia entre 500 e 800 D.C. (Cook e Bell, 1962, p. 51). O desenvolvimento dos jogos através dos tempos tem acompanhado quase todas as culturas e sociedades junto com sua evolução cultural e tecnológica (Huizinga, 1956). As interações sociais e os jogos são fenômenos socioculturais que se modificam, adaptam e evoluem continuamente (De Mul, 2005).

Desde 1978 existem pesquisas que estudam videogames e seus efeitos motivacionais na aprendizagem, bem como seu potencial cognitivo. À medida que os videogames se espalharam, nos anos 80, a pesquisa se tornou mais diversificada. Suas descobertas mostram que coordenação visual e motora podem ser desenvolvidas por jogos. Um destes estudos (Greenfield, 1985) indicou a importância dos jogos eletrônicos para as crianças com dificuldades em aprender conteúdos básicos e desenvolver habilidades cognitivo-motoras.

A década de 1990 presenciou o surgimento de grande nicho de mercado para programas com- 
putacionais tendo a família como público-alvo. Nesse período, o desenvolvimento de jogos digitais com foco na educação atraiu o interesse de empresas que começaram a reaproveitar personagens populares licenciados como Barbie, Mickey Mouse e Yoda (Kahne, 2016).

Em 2004 a iniciativa Games for Change surgiu para reunir líderes de governo, corporações, filantropia, sociedade civil, mídia, academia e indústria de jogos para explorar o crescente impacto no mundo real dos jogos digitais como um agente para a mudança social. Nos últimos anos, muitos eventos adotaram a mesma ideia, como, por exemplo, o Games for Change Festival, que tornou-se um evento importante para integrar interesses comerciais com os de mudança social.

A "Aldeia Global" anseia por uma mudança também na educação e no aprendizado (Marshall , 1977). Discussões divulgadas em alguns estudos (Lourenço, 2012) investigam as contribuições da introdução de novos conceitos e paradigmas, favorecidos pelas tecnologias emergentes, na educação. Esses conceitos, entretanto, ainda se encontram distantes do conhecimento e da formação dos professores.

Silva (2015) destaca que a escola pública, junto ao estado, enfrenta dificuldades em superar barreiras administrativas, pedagógicas e de infraestrutura. O Brasil apresenta grandes desafios no que tange a adoção de políticas públicas para melhorar o ensino e aprendizagem. Muitas dificuldades de apropriação de técnicas e métodos por professores são consequência de acesso inadequado a recursos para formação docente e precária infraestrutura disponível para uso de novas tecnologias.

Os indicadores educacionais utilizados pelo Instituto Nacional de Estudos e Pesquisas Educacionais Anísio Teixeira (INEP) ${ }^{1}$ junto com alguns gráficos do Relatório Educação para Todos no Brasil 2000-2015 (MEC, 2014) ilustram a realidade da educação brasileira em relação ao desempenho reduzido dos alunos no Ensino Fundamental e Ensino Médio em Língua Portuguesa e Matemática, avaliados por provas externas, como o Sistema de Avaliação da Educação Básica (SAEB), o Exame Nacional do Ensino Médio (ENEM) e a Prova Brasil.

Esta realidade levou o autor desta tese a reflexões sobre o fato da necessidade de se buscar novas posturas metodológicas que o possibilitem refletir sobre sua própria prática, por acreditar que o uso de jogos digitais podem contribuir para reverter o quadro dos reduzidos índices de desempenho matemático apontados.

O autor desta tese considera que em uma primeira dimensão, no contexto do currículo formal, a metodologia e a seleção de recursos e procedimentos têm apresentado intrínseca relação com a inexistência de aprendizagem significativa na Matemática e na ampliação do desenvolvimento de habilidades de raciocínio. Acredita também que há um currículo oculto, onde alunos não têm sido considerados no contexto em que vivem e nem como protagonistas de suas aprendizagens. Estes aspectos fazem parte de outra dimensão do currículo formal a ser considerado, como também as deficiências da formação docente, a burocracia e a gestão escolar, bem como a deficiente infraestrutura tecnológica presente nas escolas públicas.

A presente investigação tem como hipótese que os jogos digitais proporcionam prazer, ativam o interesse das pessoas e propiciam a participação voluntária e autônoma. Funcionam como territórios para experimentação, simulação, descoberta de resolução de problemas etc. Funcionam também como representações gráficas icônicas, animadas, de padrões da realidade que podem tornar o aprendizado potencialmente motivador. Os jogos digitais, presentes no contexto dos estudantes,

\footnotetext{
${ }^{1}$ Alguns indicadores: média de alunos por turma; média de horas-aula diária; taxas de distorção idade-série; taxas de rendimento, entre outros, vêm revelando, até o momento atual, o grave problema social que se tornou o ensino e a aprendizagem nas escolas privadas e públicas do Brasil
} 
favorecem o desenvolvimento cognitivo de competências necessárias e recomendadas pela legislação educacional brasileira, presentes no conteúdo curricular de Matemática.

Seriam os jogos digitais estratégia de fortalecimento para o desenvolvimento de competências para a aprendizagem de Matemática? O que dizem os estudos sobre a possibilidade de redesenhar a experiência de aprendizagem na escola? Como podem ser articulados os jogos digitais com o currículo escolar? Os professores reconhecem esta estratégia e elaboram projetos nesta direção? Poderiam os jogos digitais preparar os estudantes para as habilidades que serão necessárias no futuro?

Diante dos questionamentos citados, os objetivos (geral e específicos) desta investigação são:

\section{Objetivos gerais}

- Investigar e avaliar as contribuições dos jogos digitais para o desenvolvimento da aprendizagem de conceitos matemáticos.

\section{Objetivos específicos}

Como objetivos específicos temos:

1. Identificar o estado de conhecimento do uso de jogos no currículo da Matemática em estudos anteriores sobre Ensino Fundamental II.

2. Realizar pesquisa-ação em escola para a aplicação dos jogos digitais aliados às atividades docentes já existentes na escola.

3. Observar, descrever e avaliar barreiras, dificuldades, necessidades e anseios dos alunos e professores.

4. Vivenciar possibilidades de criação de oportunidades na escola para o uso de jogos digitais integrados ao currículo da Matemática.

5. Avaliar as contribuições do uso de jogos digitais para o fortalecimento de competências existentes no currículo de Matemática.

6. Identificar possibilidades de transformações metodológicas com o uso de jogos digitais. 


\section{Capítulo 1}

\section{Jogos Digitais e aprendizagem de Matemática}

Neste capítulo serão abordados temas referentes ao conceito e à definição do termo jogo e jogo digital, a origem histórica, a caracterização de tipologia dos jogos digitais e as perspectivas de uso no contexto escolar, apoiadas por Tecnologias Digitais de Informação e de Comunicação (TDIC) com intencionalidade educativa.

O jogo é uma forma estruturada de brincar que remonta à antiguidade cultural da humanidade, realizada para o divertimento, entretenimento ou simplesmente para passar o tempo. Possui um conjunto de desafios, interações, objetivos e regras livremente consentidas, mas absolutamente obrigatórias, exercidas dentro de certos limites de tempo e de espaço, acompanhadas de diversos tipos de sentimentos como medo, surpresa, aflição, acolhimento, tensão, alegria, diversão e também da consciência de uma realidade alternativa (Huizinga, 1956).

A evolução tecnológica favoreceu o nascimento dos jogos eletrônicos nos EUA, por volta de 1950 (Tavares et al., 2006). Nessa época, o simples ato de manipular luzes rústicas em uma tela de osciloscópio oferecia uma experiência imersiva muito além da forma de utilização de uma televisão como meio de transmissão de informação midiática.

William Higinbotham era responsável por guiar pessoas e explicar o funcionamento do laboratório "Brookhaven National Laboratories", em Nova York. Ao ver o grande desinteresse das pessoas em sua explicação sobre física e funcionamento dos dispositivos dos laboratórios, adaptou um osciloscópio para ser utilizado como um jogo de tênis e, dessa forma, entreter o público. O aparato tecnológico ficou conhecido como Tennis For Two. Naquele momento, foi considerado algo sem importância (Vicente et al., 2005), porém hoje é considerado o primeiro videojogo.

Na década de 1970, o primeiro videogame lançado comercialmente foi o Pong, criado pelo engenheiro Al Alcorn, da Atari, uma das primeiras empresas de jogos da história, com o crescimento mais rápido da história dos EUA (Kent, 2010). No jogo Pong (Atari, 2012), de lógica simples, um jogador disputava contra a máquina (ou contra outro jogador) uma partida de ping-pong. Com a introdução de Pong no mercado, deu-se início à indústria de videogames.

Depois do Pong, a tecnologia voltada para os jogos cresceu rapidamente através dos anos 1970. O final dessa época, e boa parte dos anos 1980, foi o período da "Era Dourada dos fliperamas"1

\footnotetext{
${ }^{1}$ Um fliperama ou arcade é uma máquina de entretenimento que funciona com games disponíveis após a inserção de uma moeda. Tais máquinas normalmente ficam em estabelecimentos públicos como bares e lanchonetes.
} 
(Kent, 2010). Nessa época, a indústria dos jogos cresceu de forma acentuada, marcada também pelo surgimento dos consoles de jogos (do inglês game consoles), dispositivos eletrônicos feitos para serem utilizados em conjunto com uma televisão e dentro das residências dos consumidores. Seu grande sucesso deu início à corrida das empresas de games para a venda e o lançamento dos consoles concorrentes. A comercialização dos primeiros consoles foi realizada em 1972 nos EUA, com o Magnavox Odissey,e em 1983 no Brasil, com o Atari.

Game design, ou projeto de jogos, em português, é o termo utilizado para se referir ao projeto de jogos digitais. Engloba diversos aspectos dos vários ciclos de desenvolvimento, onde são atribuídas funções aos desenvolvedores e também onde decisões são tomadas acerca dos conteúdos, e, ainda, são definidos princípios importantes como jogabilidade e gameplay.

A jogabilidade reflete a experiência de jogar, de manter os controles dos personagens, de realizar ações e de como poderão ser resolvidos os problemas apresentados nos jogos digitais; as regras; e a história para o game em desenvolvimento.

No projeto de um jogo digital são definidos alguns elementos como: narrativas; identidade visual e arte gráfica envolvidas; como se dará o progresso do jogo; recursos envolvidos na trama, bem como os recursos computacionais necessários para a execução; sistemas de recompensa; além da monetização (Schell, 2011; Schuytema, 2008).

O gameplay se refere ao que acontece durante a execução do jogo. Tanto pode se referir à jogabilidade e à experiência de um jogador dentro do game como a um intervalo de tempo jogado por uma determinada pessoa. O significado inclui todas as experiências do jogador durante a sua interação com os sistemas de um jogo, especialmente jogos formais, e descreve a facilidade no ato de jogar, a quantidade de vezes que ele pode ser completado ou a sua duração. O uso próprio do termo está acoplado em referência a "o que o jogador faz". Geralmente, jogabilidade, na terminologia dos jogos eletrônicos, é a expressão usada para descrever a experiência geral de um jogador em relação aos controles e desafios de um jogo (Schuytema, 2008).

Jogo móvel ou, em inglês, mobile game é um jogo digital que pode ser jogado em algum dispositivo móvel como: smartphone, celular, tablet, PDA etc. Tetris foi o primeiro jogo móvel lançado para celular, em 1994, disponível em um modelo Hagenuk MT-2000 (Hagenuk, 2012). Em 1997 um jogo, famoso nos dias de hoje, chamado Snake (Noyons et al., 2011, pp 9) foi lançado em um modelo de celular da Nokia (Nokia, 2005). A empresa estima que foram comercializados cerca 350 milhões de dispositivos móveis com tal game.

O primeiro conteúdo disponível para download em dispositivos móveis surgiu na Europa em 2000 no portal Les Games, da companhia Orange France. Os jogos eram baseados na plataforma Java ME. O mercado de jogos móveis mudou radicalmente em 2008, quando a Apple App Store foi lançada. A Google Play, ou Google Play Store, originalmente chamada de Android Market, também lançada em 2008, é uma plataforma de distribuição de aplicativos digitais para dispositivos móveis com sistema operacional Android (Butler, 2011).

Os jogos digitais evoluíram e se tornaram populares pelos consoles, porém não são exclusivos desta plataforma. Ao longo do tempo, também evoluíram os jogos para computadores pessoais ou Personal Computer (PC), bem como dispositivos móveis com celulares e os consoles portáteis (ou, em inglês, Handheld game consoles).

Pode-se dizer que jogos digitais são intangíveis, executados por um dispositivo eletrônico que serve de interface com o mundo real. Esses dispositivos podem ser um computador pessoal ou um 
dispositivo desenvolvido somente para esse fim, chamados de vídeo-jogos (videogames) ou consoles. Os jogos digitais extrapolam a barreira do tangível por serem uma tecnologia de informação e comunicação que pode ser executada colaborativamente, cooperativamente, competitivamente, individualmente, de maneira contínua ou descontínua, presencialmente ou não. Limita-se apenas pela conectividade e pelas tecnologias presentes no dispositivo que contenha o jogo digital.

Schuytema (2008) e Rocha et al. (2010) definem jogo digital como uma atividade lúdica formada por ações e decisões que resultam numa condição final. Tais ações e decisões são limitadas por um conjunto de regras e por um universo, que, no contexto dos jogos digitais, são regidos por um programa de computador. O universo contextualiza as ações e decisões do jogador, fornecendo a ambientação adequada à narrativa do jogo, enquanto as regras definem o que pode e o que não pode ser realizado, bem como as consequências das ações e decisões do jogador. Além disso, as regras fornecem desafios a fim de dificultar ou impedir o jogador de alcançar os objetivos estabelecidos.

Jogos digitais conquistaram um espaço importante na vida das crianças, jovens e adultos, seja em casa, como lazer e diversão, ou em uma fila de banco, para passar o tempo. Hoje é um dos setores que mais cresce na indústria de mídia e entretenimento (Gee, 2003).

Gee (2003) coloca os jogos digitais no topo da Taxonomia de Bloom² com sua visão hierárquica de desenvolvimento de competências. A complexidade dos conteúdos e temas abordados nos jogos digitais começou a chamar a atenção de pesquisadores ligados ao ensino e aprendizagem. Há, no universo lúdico dos jogos digitais, percepções transdisciplinares, onde as competências previstas nos objetivos educacionais são acionadas de forma diferente, não linear, mais dinâmica e dialética, sem que seja necessariamente de forma hierárquica, como proposto por Bloom.

Figura 1.1: Taxonomia Revisitada de Bloom (Shrock, 2016)

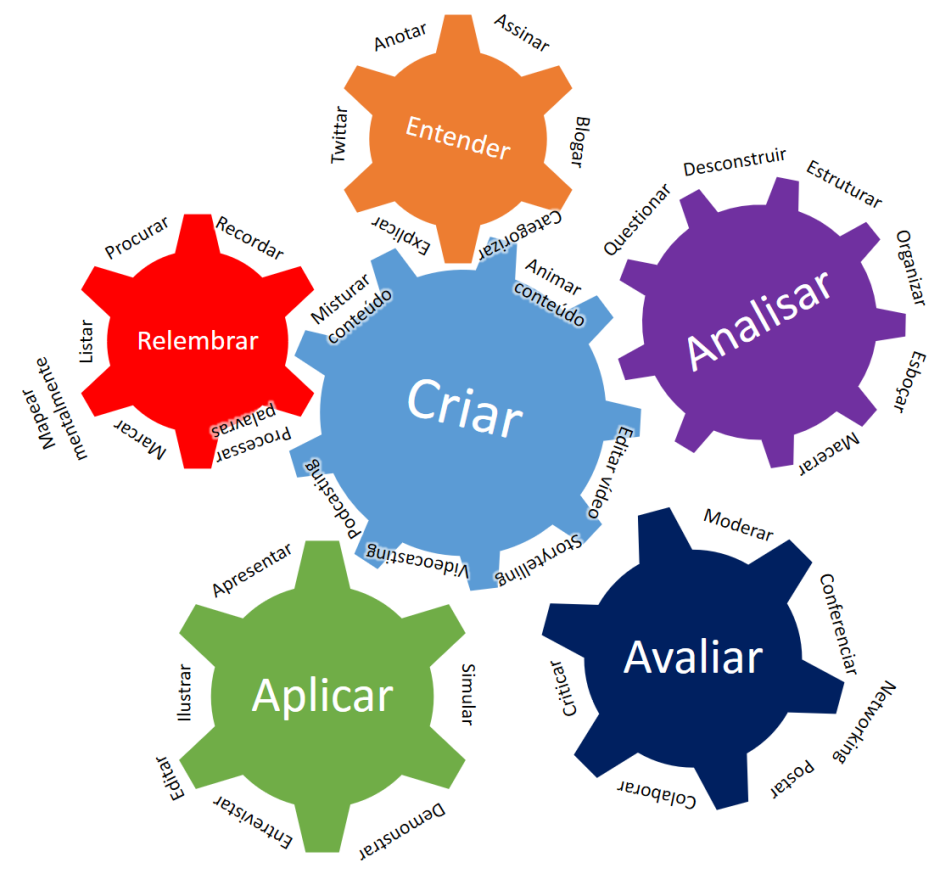

A figura 1.1 revela que, no desenvolvimento das competências de um jogo, o jogador ora analisa,

\footnotetext{
${ }^{2}$ Em 1948, durante a Convention of the American Psychological Association, discussões lideradas por Bloom levaram um grupo de educadores à classificação de metas e objetivos educacionais. Sua intenção era desenvolver um método de classificação de comportamentos que se acreditava ser importante nos processos de aprendizagem (Forehand, 2010).
} 
ora cria, aplica, entende e relembra não mais de forma hierárquica, como em uma pirâmide. As habilidades se entrecruzam, fazem iteração, de forma dinâmica, sem ter que necessariamente passar por uma escala de ordem prioritária. Há uma maior riqueza de relações e de competências envolvidas em todos os passos e/ou etapas de um jogo.

Para ilustrar, os jogos digitais Warcraft 3 e Age of Mythology são exemplos de jogos que contêm grande comunidade de fãs. Seus jogadores se reúnem em fóruns presentes na internet para: compartilhar experiências das ações executadas no jogo (relembrar); tirar dúvidas e ajudar companheiros a resolver desafios do jogo (entender); aplicar conhecimentos adquiridos previamente para resolver os problemas do jogo (aplicar); analisar boas e más atitudes dentro de um jogo, ou sugeridas em um fórum, para influenciar seu comportamento visando melhorar seu desempenho no jogo (analisar); e discutir estratégias, ações, habilidades, poderes, atitudes e comportamentos dentro das ações do jogo para que sejam obtidos melhores resultados (avaliar). Por fim, os jogos permitem que a comunidade de fãs criem conteúdos novos para o jogo, e nos fóruns essas informações são divulgadas, compartilhadas, avaliadas, assim por diante.

Prensky (2007) corrobora Gee (2003) ao afirmar que jogos digitais, além de ensinar conteúdos, ensinam como aprender, acelerando o desenvolvimento cognitivo. Johnson (2006) afirma que videogames nos ensinam a: usar um mundo imaginário envolto num quebra-cabeça de significados ocultos; usar hipóteses baseadas em descobertas e conhecimentos prévios e testar essas hipóteses na execução do jogo; e ajustar nossa compreensão de mundo de acordo com os resultados de nossas ações. Dessa forma, o autor conclui que no jogo digital a pessoa aprende o princípio básico do procedimento do método científico.

\subsection{Caracterização dos jogos digitais}

Os jogos digitais podem ser caracterizados pelo design de sua produção, por sua arte gráfica e por um conjunto de regras que definem o funcionamento do jogo e as possibilidades de ação e interação do jogador.

Alguns jogos digitais possuem um personagem principal controlado pelo jogador, mais comumente conhecido por avatar ${ }^{3}$, termo originalmente oriundo da área de realidade virtual. Um jogo digital pode ser classificado quanto ao seu design de produção, arte gráfica e funcionamento.

Os jogos digitais podem ser jogados por uma única pessoa, por múltiplos jogadores, ou multiplayer, e, dentro destes, existem os modos cooperativos, onde um jogador auxilia o outro durante a execução do jogo, e competitivos, que consistem em um jogador desafiar e agir contra outros, por exemplo, jogos de luta ou competição. É possível jogar localmente em um dispositivo com vários controles, por uma rede de computadores local, por conexão direta sem fio, usando WiFi ou bluetooth, em dispositivos móveis ou, ainda, utilizando a internet.

\section{Design de produção}

A produção de um jogo digital se refere à forma como ele é produzido, bem como seu público alvo e seus objetivos comerciais. Podem ser caracterizados, didaticamente, como:

\footnotetext{
${ }^{3} \mathrm{Na}$ área da realidade virtual, avatar é uma representação do ser inteiramente digital, uma figura gráfica de complexidade e forma variada que o usuário da aplicação utiliza como representação de si para atuar no mundo virtual ou ciberespaço.
} 
- Jogo digital independente - São jogos (também conhecidos por indie, do inglês independent) feitos por um pequeno grupo ou por apenas uma pessoa, podendo ser financiados pelos próprios produtores, ou por um pequeno valor bancado por produtoras maiores ou doações.

- Arcade - Arcade, arcada ou fliperama é um aparelho de jogo eletrônico profissional instalado em estabelecimentos de entretenimento. Compõe-se de um gabinete (caixa de madeira ou material plástico), tubo de imagem (CRT) ou monitor de vídeo, fonte de alimentação e controle(s) de jogo. Seus jogos digitais são desenvolvidos em conjunto com estas máquinas.

- Advergames - Feitos para disseminar um conceito através de um produto interativo, geralmente, mas não restrito, para publicidade de algum produto ou empresa.

- Educacional - São utilizados para atividades educacionais, geralmente em escolas e universidades. Consideram relevantes os critérios didáticos e pedagógicos associados aos conceitos que objetivam transmitir. Como exemplo, tem-se puzzles educacionais, RPG educacionais e simuladores educacionais.

- Produção Mainstream - Feitos por grandes produtoras, que contam com uma grande logística associada e podem ser considerados grandes produções como GTA e Assassin's Creed.

\section{Arte gráfica}

A classificação quanto aos gráficos se refere a como a arte e as imagens são projetadas e animadas na tela do dispositivo.

- 2D - Imagens bidimensionais, ou com duas dimensões.

- Perspectiva top-down - Visão sobre a cabeça do personagem, onde o personagem pode se movimentar em qualquer ângulo.

- Side-scrolling - Visão ao lado do personagem, muito comum em jogos de plataforma (será explicado na sessão Design e funcionamento dos jogos). O personagem geralmente se move para a esquerda e para a direita, podendo dar saltos.

- 2.5D - Gráficos em três dimensões que são visualizados a partir de uma câmera ortográfica.

- 3D - Imagens tridimensionais.

- 3D Fixo - Jogo cuja câmera é fixa em um ponto e que, geralmente, utiliza-se de uma imagem pré-desenhada ou fotografia real como plano de fundo.

- Primeira pessoa - Simula a perspectiva da visão de uma pessoa, a câmera do jogo está posicionada onde seria a cabeça do avatar.

- Terceira pessoa - Jogo em que a câmera está posicionada ligeiramente atrás do avatar, sempre acompanhando sua movimentação pelo cenário.

* Câmera fixa - A câmera simplesmente acompanha o movimento do personagem, mas não a sua rotação.

* Tracking camera - A câmera acompanha o movimento e a rotação do personagem.

* Câmera interativa - A câmera acompanha o movimento, mas quem faz a rotação é o jogador. 


\section{Design e funcionamento dos jogos}

A mecânica é um conjunto de regras que definem o funcionamento do jogo e as possibilidades de ação e interação do jogador (Pereira e Monteiro, 2012). Cada qual considerando, não necessariamente, os mesmos critérios. Dentre as características e critérios mais comuns, pode-se citar o objetivo do jogo, o contexto no qual se insere o jogador e a forma como o jogador conduz o personagem e interage com o ambiente. Battaiola (2000) propõe uma classificação consistente com a realidade atual dos jogos digitais. Um mesmo jogo pode ser classificado em duas ou mais categorias ao mesmo tempo. Essa distribuição geralmente ocorre em oito grupos:

- Ação - Jogos de ação requerem reflexos rápidos, desafios, coordenação e reação, e se subdividem em várias categorias.

- Tiro - São definidos por sua mecânica de forma a enfatizar ações envolvendo dispositivos lançadores de projéteis, geralmente armas de fogo. Jogos em primeira pessoa têm como característica definir a visão do jogador como se fosse através dos olhos do avatar. Em terceira pessoa a câmera é posicionada ligeiramente atrás do avatar. Doom, Mass Effect e Call of Duty são exemplos clássicos deste estilo.

- Plataforma - Pode ser em duas ou três dimensões; sua maior característica é a centralização dos desafios na locomoção pelo cenário do jogo. Os maiores exemplos são Mário e Sonic.

- Labirinto - Neste estilo, o jogador controla um avatar à procura da saída do labirinto. Temos como exemplo o clássico Pac-Man.

- Corrida sem fim - Também conhecidos por runner, são jogos nos quais a mecânica consiste no jogador controlar um avatar que não para de correr e precisa desviar de obstáculos.

- Sobrevivência - Literalmente o jogador precisa sobreviver, são jogos onde será necessário adquirir e consumir itens em um intervalo de tempo limitado, além de alcançar os objetivos antes que os recursos ou tempo acabem.

- Horror - São jogos que enfatizam a narrativa e a ambientação do jogo em um clima de medo, terror e horror. Geralmente mesclados com o tipo de sobrevivência.

- Furtivos - São jogos com temática e mecânicas focadas em desafios de se manter escondido dos inimigos do jogo, evitando, assim, o combate direto.

- Mundo aberto - Este estilo de jogo possui um cenário único e dá a liberdade ao jogador de ir e vir a qualquer localização do cenário. Geralmente, este estilo de jogo possui diferentes missões que podem ser realizadas na ordem de preferência do jogador.

- Simuladores - jogos que buscam imergir o usuário no ambiente que, em geral, tende a ser uma representação física do mundo real.

- Estratégia - Geralmente são jogos onde o objetivo do jogador abrange o gerenciamento de recursos, criação e gerenciamento das estratégias diversas em médio e longo prazo. O jogo pode ser por turno ou em tempo real, conhecido por RTS (Real-Time Strategy). 
- Aventura - jogos que desafiam o jogador através da exploração e de enigmas implícitos nos cenários, combinando assim o raciocínio e as capacidades psicomotoras.

- Puzzle - jogos simples que desafiam o jogador através de quebra-cabeças de solução rápida que, em sua maioria, não possuem um enredo elaborado.

- RPG - Inspirados nos tradicionais RPG (Role-Playing Game) de mesa, onde as ações são estocásticas, ou seja, cada ação tem uma probabilidade de sucesso.

- Corrida - São focados na competição usando veículos de corrida, seja em terra, água ou ar. Durante a competição de corrida, pode ou não haver a possibilidade de combate entre os corredores.

- Esporte - São jogos que simulam a prática esportiva, individual ou em equipes. Algumas das simulações de esporte podem não focar no realismo, como exemplo disso temos os jogos Mario Tênis e Quadriball Harry Potter.

- Luta - Jogos que se baseiam em lutas esportivas.

- Simulação - Jogos que têm uma temática focada no realismo. Exemplo: FIFA e Pro Evolution Soccer.

- Managers - Neste estilo, o jogador tem que administrar os esportistas, time, clube, ou assumir o papel de treinador. Exemplo: Elifoot.

- Jogo Online - Requer uma conexão com a internet. Sua mecânica e objetivos são focados na interação com outros jogadores conectados.

- Massively multiplayer online (MMO) - Permitem milhares ou até mesmo milhões de jogadores conectados no mesmo mundo virtual. Um MMO, assim como jogo online, está associado a outro estilo, geralmente RPG, tiro primeira ou terceira pessoa, RTS.

- MOBA - Sigla para multiplayer online battle arena, jogos derivados dos RTS, com batalhas online entre times cujo objetivo é destruir a base inimiga. Exemplos: DotA, League of Legends, Smite, Heroes of the Storm.

\section{Contexto Escolar}

Cabe destacar que os jogos digitais, utilizados no contexto escolar, podem configurar-se como pedagógicos e/ou didáticos dependendo da intencionalidade educativa que lhe for conferida pelo projeto pedagógico, ou de acordo com o nível de ensino e modalidade de uso em seu projeto.

Cada vez mais os jogos digitais têm sido continuamente incorporados à educação, tanto presencial quanto a distância. A diversidade de jogos eletrônicos produzidos tem mostrado, por meio de pesquisas, que eles podem oferecer uma importante contribuição para a aprendizagem. Há uma tendência a serem considerados como uma tecnologia educacional utilizada naturalmente no processo de ensino e aprendizagem por alunos e professores. Mais recentemente, o conceito de "gamificação" tem sido utilizado, o que, na verdade, não é sinônimo de uso de games (jogos digitais). É contemporâneo o conceito de ludologia, ou ludificação, que trata de abordagens multidisciplinares que agregam conceitos de diferentes áreas do conhecimento. 
A "Gamificação" tem seus pressupostos utilizados mais pela educação corporativa e necessita que esses pressupostos estejam integrados à educação escolar como um todo. Trata-se do uso de conceitos de game design, que é a atividade que cria as regras que definem as estruturas dos jogos, tendo como expectativa a geração de experiências significativas. Seus principais pressupostos envolvem: a participação voluntária e engajada como pré-condição; os desafios devem ser compatíveis com as habilidades dos usuários; as metas devem ser claras e estimulantes para influenciar o interesse e o desejo das pessoas; as respostas do sistema (feedback) devem ser rápidas, frequentes e claras; deve possuir elementos de incerteza, surpresa e aleatoriedade de potencialização de prazer dos usuários; e suas mecânicas de jogo (pontos, ranking, status, trocas, bens virtuais, "customização") devem oferecer importante papel motivacional, além de fatores sociais (competição, colaboração, coletividade, comunicação, interação) capazes de potencializar emocionalmente as experiências tendo o prazer e/ou entretenimento como meta.

As ferramentas digitais para o auxílio do ensino e aprendizagem nas instituições de ensino têm sido utilizadas e desenvolvidas na tentativa de melhorar o desempenho do aluno. Dentre essas modalidades podemos citar: e-learning, b-learning, m-learning, u-learning, BYOD, ensino a distância (EaD), jogos sérios ou serious games, business games, jogos educacionais e, até mesmo, jogos comerciais (Erhel e Jamet, 2013; Lester et al., 2014).

O e-learning, ou ensino eletrônico, são aplicações projetadas para funcionar como uma extensão das salas de aula, gerando várias possibilidades de interação virtual entre os seus participantes. A Internet é utilizada para a comunicação e a distribuição de conteúdo veiculado pela web, rede de informações. Sua relevância reside no fato de facilitar o acesso à informação, e o compartilhamento da mesma, entre alunos e professores e às questões de interdisciplinariedade envolvida nos conteúdos expostos.

Educação a distância é uma modalidade de educação, mediada por tecnologias, em que discentes e docentes estão separados espacial e/ou temporalmente, ou seja, não estão fisicamente presentes em um ambiente presencial de ensino-aprendizagem. A sua relevância se dá no fato de possibilitar uma maior flexibilidade de horários para ensinar e aprender por parte do docente e do discente, além de que um professor pode atingir mais alunos virtualmente do que poderia em uma sala de aula real. Alguns cursos virtuais, com aulas gravadas em vídeos, chegam a conter centenas e até milhares de alunos por curso.

Blended learning, ou b-learning, é um programa formal de educação no qual a maior parte dos conteúdos é ensinado a distância, normalmente usando recursos das Tecnologias de Informação e Comunicação (TIC), a outra parte do curso inclui necessariamente situações presenciais.

Pode ser estruturado com atividades síncronas ou assíncronas, da mesma forma que o e-learning, ou seja, em situações onde professor e alunos trabalham juntos num horário pré-definido, ou não, com cada um a cumprir suas tarefas em horários flexíveis. Entretanto, o blended learning em geral não é totalmente assíncrono, por exigir uma disponibilidade individualizada em encontros presenciais.

Flipped classroom é um tipo de b-learning e uma estratégia instrucional que inverte a organização tradicional de como o aluno acessa os conteúdos que serão aprendidos. O aluno primeiro tem acesso ao conteúdo fora da sala de aula, normalmente online, por páginas, artigos ou mesmo vídeos educativos. O tempo em sala de aula é utilizado para discussões, exercícios, desenvolvimento de projetos e atividades do gênero.

O aprendizado móvel fornece métodos modernos de apoio ao processo de aprendizagem mediante 
o uso de instrumentos móveis como os computadores portáteis, tablets e smartphones (UNESCO, 2014).

Os termos m-learning, mobile-learning ou "aprendizagem eletrônica móvel" se referem a metodologias de ensino e aprendizagem que usam aparelhos portáteis, como: notebook; PDA; tablets; smartphones; pocketPC; Ipod e todo e qualquer dispositivo eletrônico de mão que tenha algum tipo de conectividade nativa.

O m-learning nos leva a ambientes de aprendizagem baseados em uma tecnologia móvel estreitamente relacionada a u-learning (Ubiquitous learning, ou aprendizagem ubícua). Tal conceito faz referência à aprendizagem que pode acontecer em qualquer lugar e em qualquer momento.

Cabe destacar que a aprendizagem móvel pode ser personalizada, portátil, cooperativa, interativa e localizada no contexto, apresentando características singulares que não necessitam de espaços tradicionais de aprendizagem, mediante o uso de instrumentos digitais. Em qualquer momento e lugar existe o acesso à informação pelo dispositivo móvel eletrônico. Dessa forma, possibilita um aprendizado informal. Existe, neste caso, um potencial de transformar esse tipo de ação em ações educativas com intencionalidade pedagógica.

Os jogos fazem parte também das redes sociais (networks), serviço de rede social, site de rede social ou SNS. São plataformas para construir e compartilhar relações sociais entre pessoas que têm interesses semelhantes, atividades, fundos ou conexões na vida real. Um serviço de rede social consiste em uma representação de cada utilizador (muitas vezes um perfil), os seus laços sociais e uma variedade de serviços adicionais, como serviços de carreira. Estes serviços, baseados na web, permitem aos indivíduos criar um perfil público e criar listas de usuários com quem compartilhar os resultados e dúvidas sobre os jogos, por meio de conexões que visam cruzar as ligações dentro do sistema. As redes sociais são variadas e incorporam ferramentas de informação e comunicação, como a conectividade móvel, a fotografia, o vídeo, a partilha e os blogs (Boyd e Ellison, 2008; Buettner, 2016).

Os aspectos de caracterização, definição, classificação e conceituação dos jogos digitais revelam a elucidação do universo lúdico dos mesmos. Uma diversidade de possibilidades favorece a execução de atividades que demandam esforço cognitivo para transpor barreiras e desafios em direção aos objetivos previstos para o desenvolvimento de competências. Tais características sugerem a urgência de investigação em profundidade, com embasamento teórico, no sentido de desvelar como o uso pedagógico de jogos digitais pode potencializar o desenvolvimento cognitivo em relação ao currículo escolar.

\subsection{Características dos jogos e suas relações com a Matemática}

Os jogos digitais demandam esforço cognitivo para que o jogador possa vencer desafios e alcançar objetivos. A seguir são descritas algumas características e como estas se relacionam com o conteúdo de Matemática.

\section{HUD nos jogos digitais}

Heads-up display (HUD) é uma das características dos jogos digitais, com funções semelhantes àquelas dos painéis eletrônicos encontrados em aeronaves modernas, contendo informações importantes de monitoramento, conforme exemplo na Figura 1.2. Nos jogos digitais o HUD se refere a 
qualquer elemento visual que comunique informação ao jogador. Mini telas e mini mapas informam desde geolocalização até emoções do avatar, contêm objetivos, o que fazer, aonde ir, como fazer, quantidades de recursos e assim por diante, conforme mostra a Figura 1.2. O HUD é um elemento chave, pois é a forma direta que o jogo digital usa para se comunicar com o jogador. Essa comunicação se dá por símbolos, números, frases, desenhos e assim por diante. Dessa forma, o próprio jogo tem que ensinar o jogador a ler, interpretar e usar as suas informações; assim começa um aprendizado. A maioria dos jogos, por usar dados numéricos, exige algum conhecimento matemático. Os jogos, muitas das vezes, usam medidas e grandezas próprias, condizentes com a realidade do jogo, o que favorece estabelecer relações com a realidade e os conteúdos curriculares de Matemática.

Figura 1.2: Exemplo de HUD

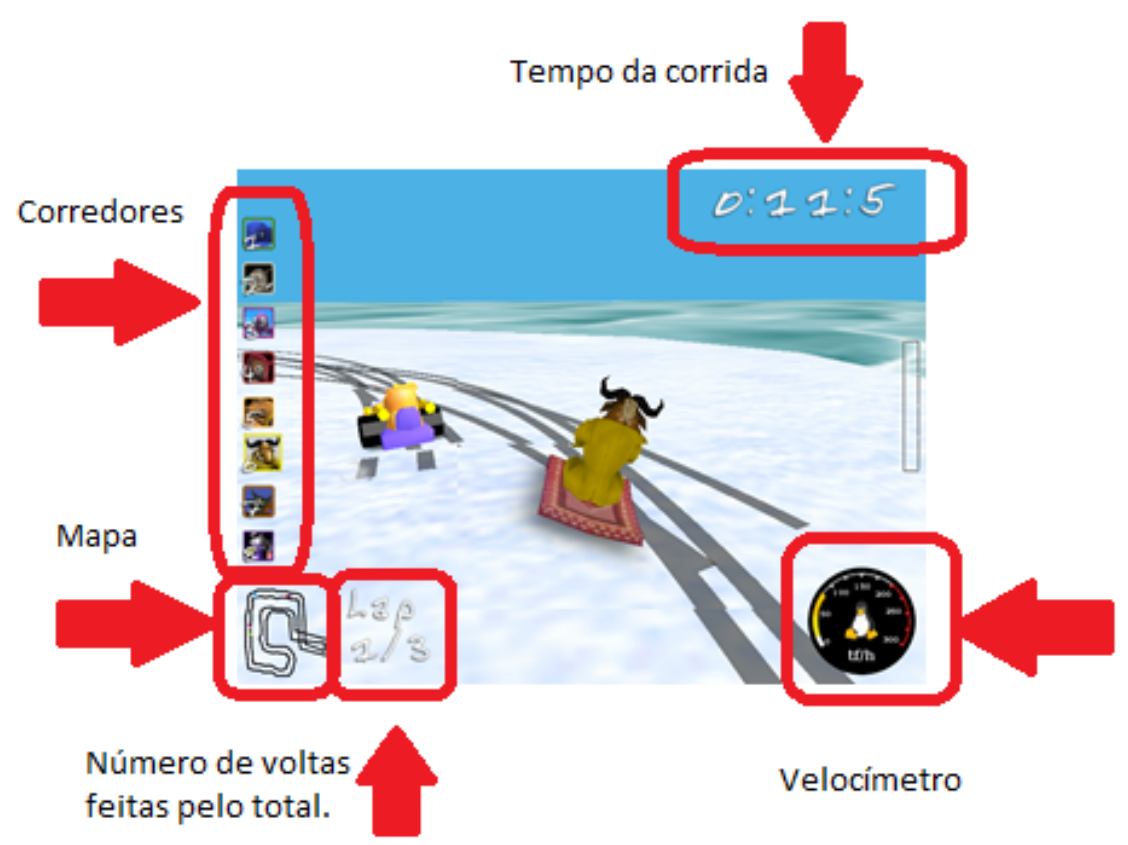

Os elementos presentes do HUD podem articular competências e habilidades previstas no currículo escolar da Matemática em todas as suas frentes, a saber: Aritmética, Álgebra, Geometria, Geometria Analítica, Porcentagem e Estatística, entre outras. Por exemplo, no game SimCity BuildIt, o HUD contém informações diretas em formas de gráficos, área e porcentagem. O jogador precisa entender tais conceitos matemáticos para compreender o papel dessas informações no game.

\section{Mecânica dos jogos digitais}

A mecânica de um jogo digital contém um conjunto de regras de funcionamento que regulam tudo que se passa no mundo virtual do mesmo. Inclui: a) como o jogador, ou qualquer outro personagem no jogo, pode se movimentar; b) que leis da física podem estar presentes; c) a probabilidade de acontecimentos pode ser provocada pelo jogador ou pelo próprio sistema. Porém, existem jogos digitais onde o aprendizado da mecânica pode estar ligado diretamente aos conteúdos do currículo escolar. Nesse caso, aprender e utilizar noções de física, como gravidade, "ação e reação", implica no entendimento da mecânica do jogo para que se consiga realizar os objetivos previstos no jogo digital de forma adequada. Por exemplo, indiretamente pode-se calcular a trajetória das aves em cálculos matemáticos articulados aos conteúdos escolares, conforme o trabalho de Avraamidou et al. (2015a). 


\section{Level}

Cenário, ou Level, é onde o jogo se realiza, onde atua o avatar que o jogador controla. O cenário contém obstáculos, inimigos e objetivos que desafiam o jogador. Também contém elementos que demandam conhecimentos prévios em algumas disciplinas, como Física e Matemática, para que o jogador consiga transpor os desafios do jogo e alcançar seus objetivos.

\section{Jogabilidade}

Jogabilidade, ou em inglês Gameplay, é um conjunto de propriedades que descrevem a experiência do jogador usando um sistema de jogo específico, cujo principal objetivo é o de proporcionar diversão e entretenimento, por ser crível e satisfatório, quando o jogador joga sozinho ou em grupos. A Jogabilidade é caracterizada por diferentes atributos e propriedades para medir as habilidades dos jogadores. Contém os seguintes elementos que podem ser considerados pelos conteúdos e competências previstas no contexto escolar:

a) Satisfação - é o grau de satisfação ou prazer para vencer e atender aos objetivos do jogo digital, ou algum aspecto dele, como: mecânica, gráficos, interface de usuário, história etc. A satisfação é um atributo altamente subjetivo, pois cada pessoa tem suas preferências e formas de obter prazer distintas, o que torna a sua medição complexa.

b) Curva de aprendizagem - é a compreensão do sentido e do significado do jogo digital para compreender e dominar o sistema de jogo e a mecânica. Por exemplo, em alguns jogos digitais, geralmente em consoles, são requeridas grandes habilidades iniciais antes de jogar. O treinamento e a repetição são condições que favorecem o entendimento e possibilitam o domínio das regras e dos recursos presentes.

c) Eficiência - é o tempo e os recursos necessários para oferecer diversão e entretenimento para os jogadores durante o ato de jogar, até que sejam atingidos os diferentes objetivos do jogo digital e seja alcançada a meta final. Um jogo digital eficiente é capaz de capturar a atenção do jogador desde o primeiro instante e provocá-lo para continuar a jogar até o fim do jogo. A eficiência pode ser analisada como o uso correto dos desafios e recompensas através do jogo, a estruturação correta dos objetivos, ou a melhor adaptação do controle para as ações no jogo.

d) Imersão - é a capacidade do jogador de acreditar ou se sentir imerso no conteúdo do jogo digital. A imersão provoca no jogador uma empatia em relação aos personagens e um envolvimento no mundo virtual, tornando-o parte deste e fazendo com que interaja com ele.

e) Motivação - representa as características que provocam o jogador a realizar ações concretas e a persistir nelas até seu ponto culminante. Para obter um alto grau de motivação, o jogo deve conter um conjunto de recursos para garantir a perseverança dos jogadores nas ações a serem realizadas a fim de superar os desafios e obstáculos do jogo. A motivação é um aspecto subjetivo, desta forma, cada jogador pode ficar motivado por diferentes fatores. Porém, o feedback imediato pode motivar um jogador a continuar até o fim do jogo, assim como outras características: ter prazer ao realizar objetivos e superar obstáculos, superar outros jogadores, explorar mundos novos e recompensas. 
f) Emoção - O jogo contém uma narrativa e estímulos diversos que provocam sentimentos no jogador. $\mathrm{O}$ uso dirigido de elementos visuais, sonoros e contextuais servem para provocar diferentes emoções no ato de jogar, como: felicidade, medo, curiosidade e tristeza. Em conjunto com os desafios, a história do jogo tem o objetivo de aumentar a imersão e a diversão do jogo digital.

g) Socialização - significa a presença de elementos no jogo digital utilizados para a comunicação e a interação entre os jogadores em um jogo multi-player. Esse tipo de experiência provoca o jogador a apreciar o game com as relações sociais que se estabelecem com outros jogadores, ou com outros personagens do jogo, com o objetivo de ajudá-lo a resolver colaborativa, cooperativa ou competitivamente seus desafios. A socialização favorecida pelo jogo permite aos jogadores terem uma experiência de jogo diferente.

A jogabilidade dos jogos digitais é responsável pela satisfação e pelo aprendizado de muitas habilidades. Quando articulada ao currículo da Matemática estudada no contexto escolar, propicia o entendimento do que se faz no jogo e de como podem ser representados por algorítimos, conferindo satisfação tanto ao ato de jogar como à compreensão de seus registros notacionais abstratos. A escola, tradicionalmente, inicia a partir do algorítimo para depois encontrar exemplos ou alternativas que possam conferir significado e entendimento aos alunos, comprometendo seu aprendizado. Muitas características da jogabilidade citadas ampliam oportunidades de compreensão, mantêm os alunos motivados e permitem o compartilhamento de aprendizagem dos conhecimentos matemáticos de forma socializada e coletiva.

\section{Narrativas Digitais ou Digital Storytelling}

A proposta da narrativa digital é combinar a antiga arte de contar histórias com os recursos das chamadas tecnologias digitais de informação e comunicação. As narrativas são elaboradas na perspectiva de linguagens múltiplas, lançando mão de recursos de multimídia (texto, fotografia, vídeo, áudio e gráfico). Na narrativa digital aplicada à educação, temos relatos de eventos históricos, histórias de vida pessoais, da comunidade escolar ou do seu entorno. O essencial é que seja sempre algo que tenha significado para o aluno.

Em relação ao uso de jogos digitais, as histórias e o contexto do próprio jogo podem ser contados por vídeos, imagens, sons e mesmo diretamente na mecânica e ações do jogador. As tramas e as narrativas em jogos geralmente têm uma estrutura claramente definida e simplista, linear. Porém, existem jogos digitais onde a narrativa é complexa e muda de acordo com as decisões e ações do jogador (Almeida e Valente, 2012).

A narrativa de um jogo digital pode ser totalmente fictícia ou baseada em histórias reais. As narrativas são importantes para que o jogador se mantenha motivado e engajado. Elas são responsáveis por manter e provocar a curiosidade, as emoções e a imersão. A narrativa está ligada a outros elementos, como a jogabilidade. Um exemplo para o ensino de História real é o jogo Assassins Creed, onde vários elementos históricos são apresentados ao jogador, tais como: 1) As tensões entre cristãos e muçulmanos nas cruzadas; 2) a atuação das ordens militares religiosas conhecidas como templários; 4) a existência de uma ordem religiosa militar muçulmana, a Ordem dos Hassassins, ou assassinos, fundada no século IX por Hassan ibn Sabbah, o Velho da Montanha. A ambientação 
geográfica e sociocultural, as construções e os prédios históricos procuram se aproximar do que eram de fato na época em que a narrativa do jogo se passa.

Outro exemplo, ligado aos conteúdos de Matemática, é o caso do Clash of Clans, onde diferentes habilidades dos conceitos matemáticos podem ser trabalhadas, como pode-se observar pelo fato do jogo estar repleto de gráficos em forma de barras, dentre outros elementos. Muitos dados matemáticos e estatísticos são utilizados para fornecer ao jogador informação suficiente para que este possa montar e gerir sua vila adequadamente, bem como definir estratégias de guerra com suas tropas para as batalhas.

Essas novas facilidades tecnológicas têm levado diversos autores a repensar as teorias de aprendizagem para englobar as características da era da mobilidade, entendida não só pelo fato de se usar tecnologias móveis como os laptops, celulares e tablets, mas também pela mobilidade das pessoas e da informação e, por conseguinte, do contexto de aprendizagem que é criado (Valente e Almeida, 2014). 


\section{Capítulo 2}

\section{Trajetória Metodológica}

Este capítulo aborda assuntos referentes à natureza epistemológica da pesquisa, seus procedimentos metodológicos, adotados para realizar a presente investigação, e a trajetória do investigador na coleta de dados sobre a realidade investigada com a finalidade de alcançar os objetivos previstos.

A pesquisa, de natureza qualitativa, configura-se como pesquisa-ação, com intuito de apreender a realidade em seu contexto e compreender o impacto que jogos digitais podem causar, tanto por serem um fenômeno social quanto como estratégia de aprendizagem.

A pesquisa-ação adota procedimentos cujo encaminhamento pode levar à compreensão de uma situação prática e à proposição de alternativas para o problema posto sob pesquisa. Possui caráter colaborativo, o que pode fundamentar transformações positivas geradas ao longo do processo de envolvimento do pesquisador e dos participantes nela envolvidos. A construção das questões de pesquisa, a seleção de procedimentos e técnicas e a interpretação de seus resultados são elementos da pesquisa-ação que buscam um vínculo com o contexto pesquisado.

Ela é gerada sob a perspectiva de um processo de comunicação colaborativa, no qual todas as contribuições dos participantes são levadas a sério. O significado construído neste processo conduz as reflexões sobre a ação na direção de novos caminhos e significados. A heterogeneidade encontrada (sujeitos, funções, ambientes, recursos e estratégias) apresenta-se como mais uma oportunidade para enriquecimento do processo de pesquisa-ação, centralizando sua atenção na resolução alternativa de algum desafio do contexto encontrado (Chizzotti, 2006).

Na literatura encontram-se algumas definições para pesquisa-ação.

"Ação deliberada visando a uma mudança no mundo real, engajada numa escala restrita, englobada por um projeto mais geral e submetendo-se a certas disciplinas para obter efeitos de conhecimentos ou de sentidos" (Dubost, 1987)

"Trata-se de pesquisas nas quais há uma ação deliberada de transformação da realidade; pesquisas que possuem um duplo objetivo: transformar a realidade e produzir conhecimentos relativos a essas transformações" (Hugon e Seibel, 1988)

Admite-se que numerosas pesquisas-ações, ainda hoje, enveredam pelo mesmo caminho de uma metodologia da ação, nada modificando, no essencial, a ordem dominante da cientificidade (Barbier , 2007). As pesquisas empreendidas por Lessard (Lessard-Hébert, 1991), por exemplo, no meio educativo, não transgridem a ordem científica tradicional. Embora se inspire no ciclo em espiral da pesquisa-ação, a metodologia é totalmente ordenada e disciplinada. 
Na pesquisa-ação é criada uma situação social dinâmica, radicalmente diferente daquela criada na pesquisa tradicional. O processo, o mais simples possível, desenrola-se frequentemente com imersão na realidade investigada por um tempo longo e os membros do grupo envolvido tornam-se íntimos colaboradores.

No momento inicial, conhecido como fase exploratória ou piloto, ocorre um momento de preparação onde torna-se indispensável analisar a literatura (referências) existente sobre o tema investigado, para que se possa elaborar o plano de ação da pesquisa e seu processo. Ter clareza nos objetivos previstos (desde sua configuração precisa sobre as evidências a serem investigadas), nos motivos de realização de um estudo específico e no caminho (o método para sua realização) requer objetivos compatíveis com as fontes disponíveis. Ainda nesse momento, o contato com todas as pessoas envolvidas pode garantir a posterior triangulação dos dados, o que confere validade científica pela maior aproximação da realidade investigada. Importante também é a empatia que pode estabelecer-se com os participantes que permitem ou autorizam a viabilidade ética do estudo, item crucial para o bom êxito da pesquisa (Apêndice A e E).

Posteriormente, o trabalho de campo permite a coleta sistemática de informações, que pode ser feita pelo acesso a múltiplas fontes, tais como foram utilizadas na presente investigação, a saber: leitura de documentos oficiais (Currículo estadual ${ }^{1}$, Parâmetros Curriculares Nacionais ${ }^{2}$, Resoluções sobre o funcionamento da escola ${ }^{3}$ e Programa Especial de Tecnologia da EE Fernando Nobre - Anexo A); entrevistas e formulários (Apêndice C, D, E e F); planejamentos das oficinas matemáticas (Anexo B) e planejamento das oficinas com jogos digitais (Apêndice I); diários de campo (Apêndice K); grupos focais (Apêndice L); gravações de voz, vídeo e fotos (Apêndice J); redes sociais (Anexos C e D); e estudos no Grupo Alpha (Anexo E).

Para Barbier (2007), devem ser abordadas quatro temáticas quando se fala de pesquisa-ação: a identificação do problema e sua contextualização; o planejamento e a realização em espiral; as técnicas de pesquisa-ação e teorização; e a avaliação e publicação dos resultados.

A pesquisa-ação adota um encaminhamento para servir de instrumento de mudança social. Essa modalidade de pesquisa está mais interessada no conhecimento prático do que no conhecimento teórico. O conhecimento prático é aquele que vem da experimentação e das aplicações do objeto a ser pesquisado. O conhecimento teórico é aquele que vem de pesquisas bibliográficas e simulações virtuais do objeto de pesquisa.

Na pesquisa-ação, o pesquisador conduz as ações, participa do ambiente em que as investigações são realizadas. Então um relatório contendo suas observações e impressões do que foi vivenciado é construído e triangulado com outros dados coletados, para que suas interpretações e entendimentos se aproximem mais da realidade investigada.

\footnotetext{
${ }^{1}$ Currículo escolar do estado de São Paulo - Matemática e suas tecnologias. Disponível em $<$ http://www.educacao. sp.gov.br/a2sitebox/arquivos/documentos/783.pdf> Acesso em Ago 2015.

${ }^{2}$ Parâmetros Curriculares Nacionais. Disponível em <http://portal.mec.gov.br/seb/arquivos/pdf/matematica. pdf > Acesso em Ago 2015.

${ }^{3}$ Resoluções: SE 6 de 19/01/2016; SE 75/2014; 73 de 29/12/201. Disponíveis respectivamente em:

$<$ http://siau.edunet.sp.gov.br/ItemLise/arquivos/6 16.HTM?Time $=21 / 01 / 2016 \% 2008: 43: 44>$

$<$ http://siau.edunet.sp.gov.br/ItemLise/arquivos $/ 7 \overline{3} \_$14.HTM?Time $=10 / 02 / 2017 \% 2013: 56: 25>$
} 


\subsection{Entrevistas com professores e alunos}

As entrevistas foram informais e formais, estruturadas e semi-estruturadas, em todas as oportunidades vivenciadas com os alunos na escola. O Apêndice E apresenta as questões formuladas como sondagem diagnóstica para subsidiar o projeto com os jogos digitais. Foram de grande valia para sistematizar os procedimentos de preparação e implementação do projeto Games e o Ensino da Matemática.

As perguntas foram elaboradas e validadas pela pesquisadora Stela Piconez (responsável pelo Grupo Alpha) de forma a não sugerir respostas e não perguntar diretamente a questão investigada, buscando evitar a indução do entrevistado pelo pesquisador. Através de perguntas como "O que você achou de receber informações pelo personagem X do jogo?", "O que você notou de interessante na fase 1 do jogo?", os entrevistados apresentaram seus próprios pontos de vista, respondendo livremente sobre as questões colocadas. As declarações dos entrevistados, relacionadas com o objetivo da pesquisa, foram investigadas de maneira mais aprofundada através de novas perguntas, tais como "Por que...", "Como..." e "Fale um pouco mais sobre isto".

As entrevistas individuais foram executadas, a princípio, antes de começarem de fato os experimentos com jogos digitais, para que se pudesse conhecer os participantes, a escola e seu contexto, para que se pudesse planejar os experimentos, bem como constatar sua aceitação pelos participantes.

Foram realizadas entrevistas com as professoras de Matemática responsáveis pelas Oficinas Experiências Matemáticas dos $7^{\circ}, 8^{\circ}$ e $9^{\circ}$ anos da escola. E com todos os professores da escola, para sondagem inicial e reconhecimento do campo de pesquisa (Apêndice F), foram informais, cujos registros foram gravados e descritos nos diários de campo (Apêndice K).

\subsection{Avaliação com Grupos Focais}

Os grupos focais constituem uma técnica de pesquisa qualitativa para coleta de dados utilizada quando se dá a ausência de medidas numéricas e análises estatísticas. A técnica de grupo focal (GF) teve início no final da década de 1940, desde então tem sido utilizada e aprimorada como metodologia de pesquisas sociais, principalmente aquelas que trabalham com avaliação de programas, marketing, regulamentação pública, propaganda e comunicação. Traz a possibilidade de obtenção de dados válidos e confiáveis (Trad, 2009).

Os grupos focais são uma forma de avaliação em grupo sobre um tema ou atividade realizada cujas discussões favorecem a compreensão do fenômeno observado sob a ótica dos participantes da pesquisa. Ocorrem em um lugar previamente selecionado e são dirigidos por um mediador, sem necessariamente limitar-se ou obrigar-se a ele. O objetivo central é identificar sentimentos, percepções, atitudes e ideias dos participantes a respeito de determinado assunto. Os participantes dos grupos focais podem ser provocados, além de serem encorajados, a participar, lembrando ou dizendo algo que previamente possa ter sido considerado como não importante a se dizer. A conversa e discussão entre participantes clarifica os pontos de vista pessoais e com isso fomenta a coleta de informações valiosas.

Para dar prosseguimento a uma pesquisa baseada nesta técnica, é necessário haver um moderador que administre o diálogo e estimule um ambiente de troca, onde as pessoas se sintam à vontade para compartilharem suas ideias e opiniões. O mediador é a peça-chave do sucesso de uma pesquisa baseada em grupos focais (Kitzinger, 1995). 
Nesta pesquisa, os grupos focais foram executados pelo pesquisador responsável e por pesquisadores do grupo Alpha na Escola Estadual Fernando Nobre, em horário de aula, previamente agendado e autorizado pela equipe gestora da escola. Os áudios do grupo focal foram gravados e transcritos, e constam no Apêndice L.

\subsection{Diários de campo}

Consiste num dispositivo individual para anotações, seja ele um caderno, um fichário, um tablet, um gravador de voz e assim por diante, com espaço suficiente para registrar percepções, observações, comentários e reflexões coletadas em campo (Apêndice K). Nele se anotam todas as observações de fatos concretos, os fenômenos sociais, os acontecimentos, as relações verificadas e as experiências pessoais do investigador durante as investigações em campo. O diário de campo facilita criar o hábito de escrever e observar com atenção, descrever com precisão, refletir sobre os acontecimentos e manter um registro cronológico dos experimentos. Algumas definições de pesquisadores:

"É chamado de diário de campo o instrumento mais básico de registro de dados do pesquisador. Inspirado nos trabalhos dos primeiros antropólogos que, ao estudar sociedades longínquas, carregavam consigo um caderno no qual eles escreviam todas as observações, experiências, sentimentos, etc, [...]é um instrumento essencial do pesquisador" (Víctora et al., 2000).

"É um documento que apresenta tanto um 'caráter descritivo analítico', como também um caráter 'investigativo e de sínteses cada vez mais provisórias e reflexivas', ou seja, consiste em "uma fonte inesgotável de construção, desconstrução e reconstrução do conhecimento profissional e do agir através de registros quantitativos e qualitativos'" (Lima et al., 2007).

Oriundos do campo da Antropologia e amplamente utilizado em pesquisas etnográficas, podem ter descrição densa, como por exemplo: do retrato dos sujeitos (aparência, maneira de vestir, modo de falar e agir, particularidades dos indivíduos); das visões de mundo do observado (grau de religiosidade, valores, elementos culturais ligados ao processo de trabalho, de saúde etc.); da reconstrução do diálogo (palavras, gestos, expressões faciais, pronúncias); da descrição do espaço físico (desenho espaço, mobília); do comportamento do observador (aspectos que possam interferir na coleta de dados); da descrição de atividades (detalhamento); e dos relatos de acontecimentos (forma como aconteceram e natureza das ações).

Os diários de campo foram fundamentais para o registro em ordem cronológica de todas as visitas à escola Fernando Nobre, de modo a ajudar a triangular os dados dos experimentos e a inferir reflexões acerca do que foi coletado em conjunto com as outras técnicas utilizadas para compreender o fenômeno estudado.

\subsection{Triangulação de dados}

Nas ciências sociais, a triangulação é frequentemente usada como uma alternativa à validação (Denzin e Lincoln, 1994). Essa ferramenta combina diferentes perspectivas metodológicas, diversos 
materiais empíricos e a participação de vários investigadores em um só estudo. Desta forma, esperase aumentar o rigor, a amplitude, a complexidade, a riqueza e a profundidade da investigação.

A triangulação de dados na pesquisa qualitativa vem sendo reconhecida por aumentar a credibilidade dos resultados encontrados. Vários pesquisadores têm definido a triangulação através do tempo como:

- Cohen et al. (2013) - "tentar mapear, ou explicar mais detalhadamente, a riqueza e a complexidade do comportamento humano, estudando em mais de um ponto de vista".

- Altrichter et al. (2013) - "fornece uma visão mais detalhada e balanceada da situação".

- O’Donoghue e Punch (2003) - "método de cruzamento de dados de várias fontes para procurar regularidades nos dados da pesquisa".

Nesta pesquisa, a triangulação de dados foi feita com os diários de campo, grupos focais e entrevistas individuais, opinião dos professores envolvidos na aplicação dos experimentos pessoalmente e registrados no Moodle e WhatsApp. Cada dado coletado foi analisado e discutido em várias reuniões e discussões promovidas pelo Grupo Alpha, e seus pesquisadores, servindo de insumo para a triangulação em questão e o distanciamento da subjetividade do pesquisador.

\subsection{Caracterização da Cidade e da Escola e dos Participantes}

A realidade encontrada na escola pesquisada, em termos de seu projeto pedagógico, plano de aulas dos professores, infraestrutura tecnológica reduzida e formação inadequada de professores, constituiu-se em desafios que foram enfrentados ao longo da trajetória metodológica concebida.

A Escola Estadual Fernando Nobre, campo amostral da presente pesquisa, foi criada conforme a Resolução S.E. - 24G de 28/01/69, em publicação no Diário Oficial do Estado na data de 29/01/1969. A instituição possui uma área total de 5.153,10 metros quadrados, sendo 1570 metros quadrados de área construída. A área ocupada pelo bloco de salas é de 976 metros quadrados.

Possui sete salas de aula, bastante amplas, com o mobiliário em boas condições de uso e armários embutidos. Uma dessas salas serve também como sala de vídeo e há também uma pequena sala de leitura e outra sala para informática, além da sala dos professores. O Corpo Docente é composto por 22 professores e a escola conta com 220 alunos.

A população de Cotia, verificada pelo censo em 2010, era de 201.150, e estimada em 229.548 habitantes para o ano de 2015. Sua área é de $323,994 \mathrm{~km}^{2}$, sua densidade demográfica era de 620,83 habitantes por quilômetro quadrado, ainda segundo dados de 2010, e seu bioma é a Mata Atlântica. O número de pessoas que frequentavam regularmente o ensino fundamental de escola pública em 2010 era: 26.611. A População residente de 10 a 14 anos era: 18.380. A População residente que nunca frequentou creche ou escola de 10 a 14 anos era: 50. O número de pessoas de 10 anos ou mais de idade, sem instrução e com ensino fundamental incompleto era: 71.496 (IBGE, 2010).

A economia da cidade de Cotia é bem variada, tendo como destaque as indústrias metalúrgicas, têxteis e de semicondutores. No setor industrial, localizado ao longo da Rodovia Raposo Tavares e seus arredores, os produtos mais importantes são materiais elétricos, químicos, cerâmicos, brinquedos, têxteis, explosivos, alimentos, vinho, aguardente e máquinas agrícolas. É uma cidade com a economia emergente, mas a sua distribuição de renda é desigual, gerando portanto um alto índice de pobreza. 
Índice de Pobreza, fonte IBGE (2000):

- Incidência da Pobreza: 45,80\%

- Incidência da Pobreza Subjetiva: 19,04\%

- Limite inferior da Incidência da Pobreza Subjetiva: 17,35\%

- Limite inferior da Incidência de Pobreza: $39,11 \%$

Por apresentar índices reduzidos no ranking das escolas por meio de exames externos na aprendizagem de matemática, tal escola entrou em contato com a Faculdade de Educação da Universidade de São Paulo (FE-USP), especificamente junto ao Grupo Alpha, solicitando formação tecnológica para seus professores, para que aprendessem a usar as tecnologias digitais (TDIC) na sala de aula, buscando, dessa forma, melhorar o desempenho do ensino e favorecer o aprendizado dos seus alunos.

\section{Corpo docente}

Esta pesquisa contou com uma vivência de colaboração com professores de matemática e outras disciplinas. Tal vivência foi fundamental para que o pesquisador pudesse tomar conhecimento da profundidade dos desafios e das possibilidades ao experimentar jogos digitais juntamente com os professores. A pesquisa realizada pelo grupo Alpha revelou que do total de professores, 57,1\% pertencem ao sexo feminino e $42,9 \%$ pertencem ao sexo masculino. A faixa etária do corpo docente é distribuída da seguinte forma: $28,6 \%$ possuem de 30 a 35 anos; $35,8 \%$ possuem de 36 a 40 anos; $7,1 \%$ possuem de 41 a 45 anos; e 7,1\% possuem de 46 a 50 anos. Os 21,4\% restantes não informaram. Em relação ao tempo de trabalho no magistério, a maioria trabalha de 1 a 5 anos, como mostram os seguintes dados: $57 \%$ do corpo docente tem experiência de 1 a 5 anos; $7,1 \%$ tem menos de 1 ano e $35,7 \%$ tem mais do que 5 anos.

A maioria dos professores atuam no Ensino Fundamental II e os demais ocupam funções de gestão. Todos os professores possuem graduação nas áreas das disciplinas curriculares e $21,5 \%$ deles também cursaram Pedagogia. O maior número de professores concentra-se em Língua Portuguesa e Matemática, devido à existência de carga horária maior que os demais componentes, além de carga horária nas oficinas obrigatórias como as de Experiências Matemáticas e Práticas de Leitura. No gráfico presente na Figura 2.1 podemos observar a distribuição de professores, por áreas, que atuam na escola.

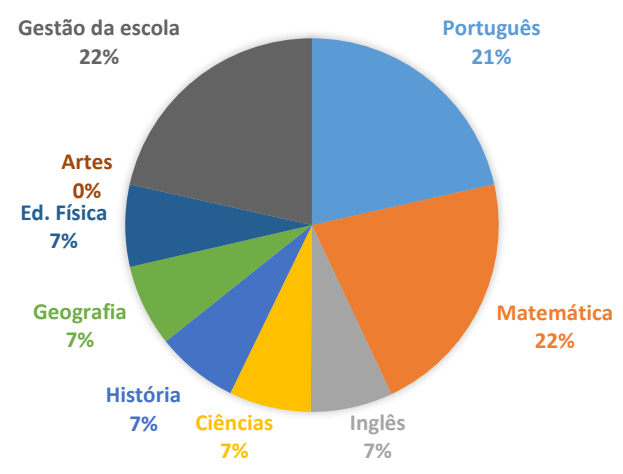

Figura 2.1: Professores por disciplina 
Em relação às TDIC, um questionário de sondagem diagnóstica dos professores sobre as tecnologias foi aplicado (Apêndice F) e seus resultados são apresentados nos Quadros 2.1, 2 e 3), sem a tabulação quantitativa por serem consideradas muito relevantes cada indicação.

Quadro 2.1: TDIC e seu uso na ótica Docente

\begin{tabular}{c||l}
\hline Categorias & Respostas \\
\hline \hline Infraestrutura & Acessibilidade democrática para fins educacionais \\
& Acesso de qualidade \\
& Possibilidade de uso em todas as disciplinas \\
& Possibilidade de uso da lousa digital \\
\hline Docência (Didática) & Ensinar os estudantes a criar com TDIC \\
& Aulas mais dinâmicas, práticas e atraentes \\
& Uso de Jogos e vídeos educacionais \\
& Criação de trabalhos diferenciados \\
& Uso de comunicação interna \\
& Uso de interatividade síncronas e assíncronas \\
& Uso de redes sociais e grupos virtuais de aprendizagem \\
& Uso da web em sala de aula para discussões em tempo real \\
& Interação com fatos do mundo todo \\
& Uso de aplicativos como Facebook, WhatsApp, Messenger, Skype \\
& Tirar dúvidas online com professores \\
& Videoconferência com professores outros estados e/ou países \\
\hline Aprendizagem & Uso de recursos para aprendizagem \\
& Agregar valores em nível de conhecimento e interesse dos estudantes \\
& Melhorar aprendizagem dos estudantes \\
& Coibir indisciplina por ser ferramenta de grande valor \\
\hline Gestão & Aprimorar a gestão educacional \\
& Aproximar escola-comunidade \\
\hline
\end{tabular}

O Quadro 2.2 revela que o corpo docente tem consciência do interesse dos alunos pela tecnologia e preferência do seu uso em atividades sociais, de criação e de pesquisa na web. Mas, em relação à aprendizagem, poucas indicações foram feitas.

O Quadro 2.3 ilustra parte dos desafios atribuídos à precariedade da infraestrutura presente na escola, reconhecendo a própria ausência de qualificação dos seus professores no uso das TDIC, mas também reafirma o interesse pela inserção da tecnologia no planejamento de suas aulas. As respostas foram agrupadas pelas categorias: infraestrutura, docência, aprendizagem e gestão.

O corpo docente não indicou mudanças em relação à aprendizagem dos alunos com notas abaixo da média. Não foi registrada nenhuma indicação de como as TDIC poderiam auxiliar na recuperação dos mesmos e nem, tampouco, se permitiram sugerir melhorias quanto à gestão da escola.

\section{Corpo discente}

A escola, campo desta investigação, encontra-se em uma cidade satélite de São Paulo denominada Cotia, em uma região carente de recursos. Cada estudante enfrenta problemas em casa de algum tipo, conforme detectado nas entrevistas. Foram apresentados, pelos professores, com estigmas de deficiências e problemas severos de aprendizagem de matemática, conforme atestam os resultados das avaliações internas e externas escolares.

Foram entrevistados $20 \%$ do total de 220 alunos, escolhidos por adesão espontânea. Apenas 
Quadro 2.2: TDIC preferidas pelos alunos na visão dos Docentes

\begin{tabular}{c||l}
\hline Categorias & Respostas \\
\hline \hline Infraestrutura & Presença de sites especializados (Pacote Office,Wikipedia, \\
& Scielo etc.) \\
& Presença de Facebook, Whatsapp, Instagran, Twiter, Google etc. \\
& Sites de música \\
& Jogos interativos \\
& Uso de celular liberado \\
& Equipamentos para criação e apresentação de vídeos \\
\hline Docência (Didática) & Uso das redes sociais para escrever em vários gêneros, música, \\
& poesia etc. \\
& Uso para pesquisa \\
& Uso para atividades lúdicas \\
& Criação de vídeos \\
& Comunicação social via redes sociais \\
& Uso de todas as TDIC \\
& Uso em pesquisas, trabalhos sobre meio ambiente \\
& Uso de músicas e imagens \\
& Uso das TDIC como entretenimento \\
& Uso de celulares para s tarefas pedagógicas \\
\hline Aprendizagem & - \\
\hline Gestão & - \\
\hline
\end{tabular}

Quadro 2.3: Mudanças sugeridas para melhor uso das TDIC

\begin{tabular}{c||l}
\hline Categorias & Respostas \\
\hline \hline Infraestrutura & Atualização de softwares \\
& Equipamentos que funcionem \\
& Conexão via internet, Wi-Fi para todos funcionando sempre \\
& Disponibilidade de tablets e mais computadores para as atividades \\
& cotidianas na sala de aula \\
& Organização de horários específicos para uso das TDIC para cada sala \\
& Presença de profissionais especializados na sala de informática \\
& Criação de uma sala na web (ambiente virtual de aprendizagem, \\
& blog etc) \\
& Melhor acesso e uso livre da internet e dos celulares \\
& Ampliar tempo destinado ao uso das mídias \\
& Instalação de lousas digitais \\
\hline Docência (Didática) & Formação e melhor qualificação para os professores \\
& Criar uma forma de comunicação apreciada pelos estudantes \\
& Implementação de cursos para saber acessar a web em todas as \\
& salas \\
& Saber usar as TDIC adequadas a cada disciplina \\
& Aprender a usar didaticamente as tecnologias móveis (tablets \\
& e celulares) \\
& Usar as redes sociais com intencionalidade pedagógica \\
& Implementação de cursos de aperfeiçoamento para professores sobre \\
& Usar mais teleconferências \\
\hline Gestão & - \\
\hline
\end{tabular}


cinco alunos declararam não possuir celulares. Apenas $6 \%$ deles não possuem computador em suas residências. A maioria dos alunos utiliza aplicativos dos smartphones para ouvir músicas durante o intervalo das aulas, assim como para acessar as redes sociais. Do total de alunos, 31,9\% usam Facebook; 30,9\% deles usam Whatsapp; 17,5\% sabem usar o Instagran e Twitter; enquanto que apenas $10 \%$ declararam que não tem o hábito de usar smartphone na escola.

A pesquisa envolveu um total de $27,2 \%$ de alunos do $8^{\circ}$ ano e do $9^{\circ}$ ano do Ensino Fundamental II, o que representou um número de 60 alunos do total da escola, sendo $58 \%$ meninas e $42 \%$ meninos. Os alunos que participaram da pesquisa são estudantes da escola Fernando Nobre, possuindo entre 10 e 15 anos, como mostra a Figura 2.2.

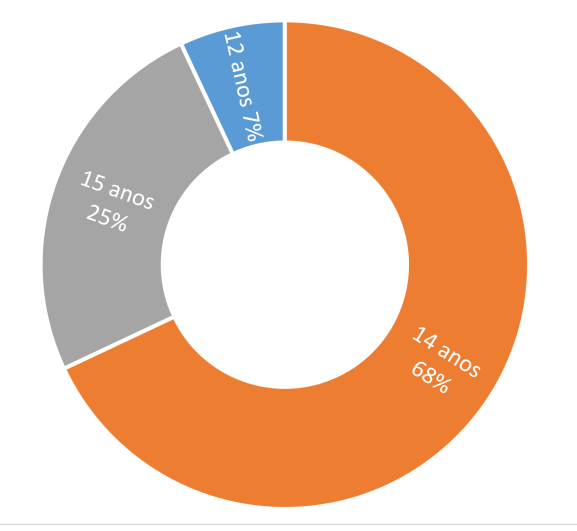

Figura 2.2: Faixa Etária dos alunos

A maioria dos alunos (81\%) afirma ter computador ou tablet no ambiente doméstico. A sondagem também apontou que $84 \%$ desses alunos possuíam telefones do tipo smartphones. Estes dispositivos móveis participam das atividades cotidianas desses estudantes, ao ponto de quase $2 / 3$ deles admitirem utilizar os aparelhos por mais de sete horas diariamente (53\% informaram que utilizam o dia inteiro). O gráfico presente na Figura 2.3 apresenta a distribuição dos alunos por tempo de utilização diária do telefone celular.

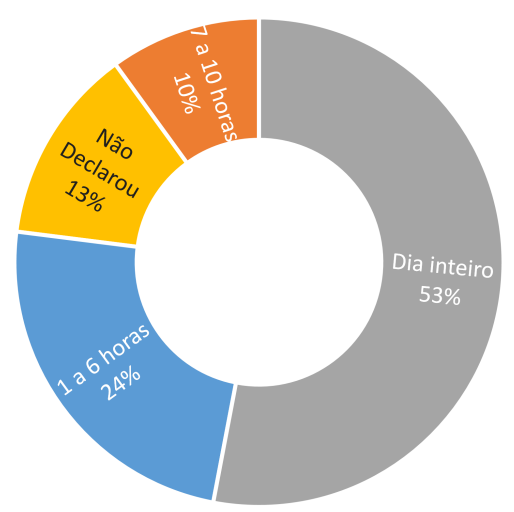

Figura 2.3: Tempo de uso do smartphone

A Figura 2.4 apresenta o gráfico das principais formas de emprego das TDIC na Educação, na perspectiva dos alunos (alguns alunos indicaram mais de uma categoria).

A maioria dos alunos tinha acesso à internet tanto via $W i-F i$ quanto via $3 \mathrm{G}$. Apenas $24 \%$ acessava exclusivamente via $W i-F i$ e um respondente possuía celular que não permitia acesso à internet. Dos dispositivos móveis, $88 \%$ utiliza o sistema operacional Android. 


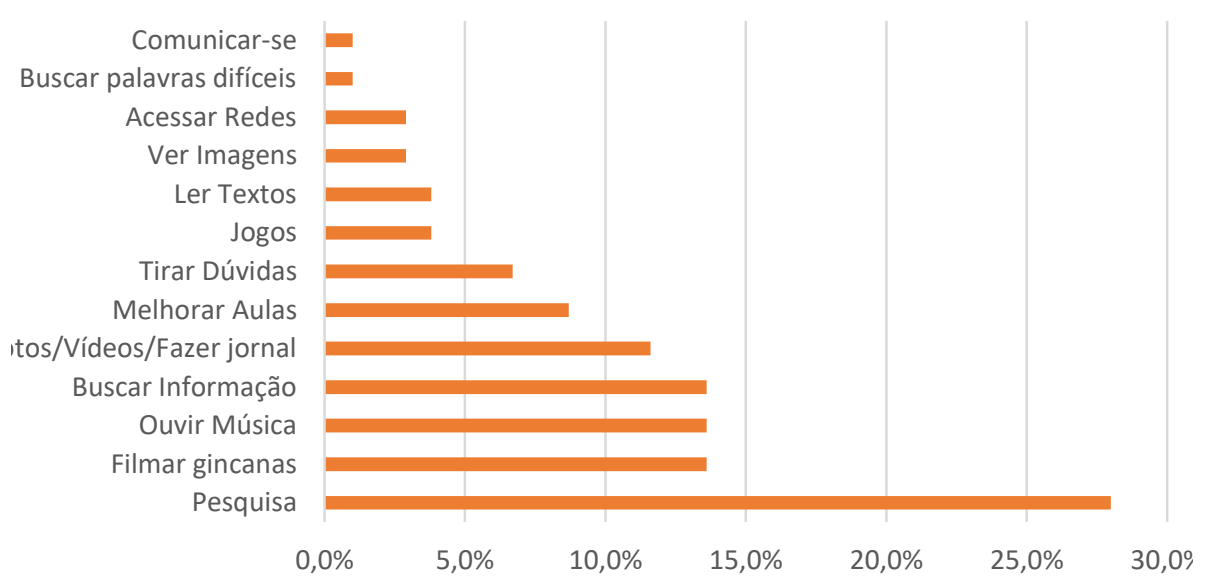

Figura 2.4: Uso de TDIC na visão dos alunos

A sondagem desvelou os variados temas de interesse dos alunos que, sob a perspectiva deles, poderiam ser abordados em conjunto com a tecnologia móvel para beneficiar a aprendizagem em sala de aula. Os temas mais referenciados foram indicados nas áreas de Ciências, História, Geografia, Idiomas, Literatura e Artes, bem como a divulgação de trabalhos realizados pelos próprios alunos.

A turma abordada em agosto de 2015 foi a $8^{\circ} \mathrm{B}$, juntamente com uma professora da oficina. O diretor solicitou que se trabalhasse em tal turma pois a mesma era a que apresentava os índices de aproveitamento escolar mais baixos. Os alunos participaram das experiências com jogos digitais por adesão espontânea. Ao final de 2015 foi executado nas turmas da escola uma avaliação de proficiência em matemática. A turma escolhida para a aplicação dos jogos digitais foi a $8^{\circ} \mathrm{B}$ em 2015, e a $9^{\circ}$ ano B em 2016. Também em 2016 outras duas turmas foram escolhidas, juntamente com uma professora responsável pelas oficinas, $8^{\circ}$ ano A de $2016\left(7^{\circ} \mathrm{A}\right.$ em 2015) e $6^{\circ}$ ano A. Este último entrou na escola em 2016 e não contêm avaliação. Os Quadros 2.4 e 2.5 contêm os resultados das avaliações.

\section{Currículo escolar}

O currículo escolar do Estado de São Paulo pode ser encontrado na íntegra no site do gorverno ${ }^{4}$, bem como os parâmetros curriculares nacionais ${ }^{5}$. A Matriz Curricular pode ser encontrada no Anexo F.

Como o foco deste trabalho é desenvolver competências em relação à disciplina de Matemática, será descrito neste tópico o currículo escolar da escola de ensino fundamental do Estado de São Paulo.

O principal objetivo do currículo em questão é mapear os conteúdos da disciplina de Matemática, buscando articulá-la a outras de modo a não estabelecer limitações e fronteiras rígidas, favorecendo a transdisciplinaridade.

O documento oficial afirma que o Estado de São Paulo apresenta expressiva herança pedagógica, consubstanciada em suas propostas curriculares e nos materiais produzidos pela Coordenadoria de Estudos e Normas Pedagógicas (Cenp) para apoiar os professores em suas ações docentes. Contém

\footnotetext{
${ }^{4}$ Currículo escolar do Estado de São Paulo - Matemática e suas tecnologias. Disponível em < http://www.educacao. sp.gov.br/a2sitebox/arquivos/documentos/783.pdf> Acesso em Ago 2015.

${ }^{5}$ Parâmetros Curriculares Nacionais. Disponível em <http://portal.mec.gov.br/seb/arquivos/pdf/matematica. pdf $>$ Acesso em Ago 2015
} 
Quadro 2.4: Habilidades em Matemática $8^{\circ}$ ano $B$

\begin{tabular}{|c|c|c|}
\hline \multirow[b]{2}{*}{ Habilidade } & \multicolumn{2}{|c|}{ Nível de proficiência } \\
\hline & 2015 & 2016 \\
\hline $\begin{array}{l}\text { Ler e/ou interpretar informações e dados apresentados em } \\
\text { gráficos e construir gráficos (particularmente gráficos de colunas). }\end{array}$ & $93 \%$ & $96 \%$ \\
\hline $\begin{array}{r}\text { Compreender o significado do teorema de Pitágoras, utilizando-o na } \\
\text { solução de problemas em diferentes contextos }\end{array}$ & $41 \%$ & $42 \%$ \\
\hline Interpretação e multiplicação com números decimais & $69 \%$ & $\mathrm{~N} / \mathrm{A}$ \\
\hline $\begin{array}{r}\text { Determinar área e perímetro de uma figura utilizando composição e } \\
\text { decomposição de figuras. }\end{array}$ & $28 \%$ & $46 \%$ \\
\hline $\begin{array}{l}\text { Resolver problemas simples de matemática discreta, buscando } \\
\text { soluções inteiras de equações lineares com duas incógnitas }\end{array}$ & $21 \%$ & $27 \%$ \\
\hline $\begin{array}{l}\text { Relacionar as linguagens algébricas e geométricas, sabendo } \\
\text { traduzir uma delas na outra, particularmente no caso de produtos notáveis }\end{array}$ & $34 \%$ & $50 \%$ \\
\hline $\begin{array}{r}\text { Compreender a ideia de número racional em sua relação com as } \\
\text { frações e as razões }\end{array}$ & $31 \%$ & $27 \%$ \\
\hline $\begin{array}{r}\text { Conhecer as condições que fazem com que uma razão entre inteiros } \\
\text { possa se expressar por meio de dízimas periódicas; saber } \\
\text { calcular a geratriz de uma dízima }\end{array}$ & $14 \%$ & $31 \%$ \\
\hline $\begin{array}{l}\text { Reconhecer e saber utilizar o conceito de razão em diversos } \\
\text { contextos (proporcionalidade, escala, velocidade, porcentagem, } \\
\text { etc.), bem como na construção de gráfico de setores } 21 \%\end{array}$ & $12 \%$ & \\
\hline Realizar operações simples com monômios e polinômios & $21 \%$ & $19 \%$ \\
\hline
\end{tabular}

competências básicas a serem desenvolvidas pelos alunos ao longo da escola básica, incluindo três pares complementares de competências, que constituem três eixos norteadores da ação educacional:

- O eixo expressão/compreensão: a capacidade de expressão do eu por meio das diversas linguagens e a capacidade de compreensão do outro, do não eu, do que me complementa, o que inclui desde a leitura de um texto, de uma tabela, de um gráfico, até a compreensão de fenômenos históricos, sociais, econômicos, naturais etc.;

- O eixo argumentação/decisão: a capacidade de argumentação, de análise e desarticulação das informações e relações disponíveis, tendo em vista a viabilização da comunicação e da ação comum, a construção de consensos e a capacidade de elaboração de sínteses de leituras e de argumentações, tendo em vista a tomada de decisões, a proposição e a realização de ações efetivas;

- O eixo contextualização/abstração: a capacidade de contextualização dos conteúdos estudados na escola, de enraizamento na realidade imediata, nos universos de significações, sobretudo no mundo do trabalho, e a capacidade de abstração, de imaginação, de consideração de novas perspectivas, de virtualidades e de potencialidades para se conceber o que ainda não existe.

O currículo prevê o uso de recursos tecnológicos para auxiliar as atividades docentes, além de reconhecer que estes podem ser poderosos aliados, desde que usados com um plano pedagógico. 
Quadro 2.5: Habilidades em Matemática ro ano $A$

\begin{tabular}{|c|c|c|}
\hline \multirow[b]{2}{*}{ Habilidade } & \multicolumn{2}{|c|}{ Nível de proficiência } \\
\hline & 2015 & 2016 \\
\hline $\begin{array}{r}\text { Realizar de modo significativo as operações de adição, subtração, } \\
\text { multiplicação e divisão de números negativos }\end{array}$ & $36 \%$ & $42 \%$ \\
\hline Identificar a representação fracionária na reta numérica. & $23 \%$ & $38 \%$ \\
\hline $\begin{array}{l}\text { Resolver problemas simples envolvendo a ideia de probabilidade } \\
\text { (porcentagem que representa possibilidades de ocorrência). }\end{array}$ & $32 \%$ & $21 \%$ \\
\hline $\begin{array}{r}\text { Conhecer o significado do número } \pi \text { como uma razão constante da } \\
\text { Geometria, sabendo utilizá-lo para realizar cálculos simples } \\
\text { envolvendo o comprimento da circunferência ou de suas partes }\end{array}$ & $41 \%$ & $29 \%$ \\
\hline $\begin{array}{r}\text { Fazer a transposição entre a linguagem corrente e a linguagem } \\
\text { algébrica. }\end{array}$ & $27 \%$ & $13 \%$ \\
\hline Identificar elementos de poliedros e classificá-los. & $73 \%$ & $46 \%$ \\
\hline $\begin{array}{r}\text { Resolver problemas variados, envolvendo grandezas direta e/ou } \\
\text { inversamente proporcionais. }\end{array}$ & $27 \%$ & $29 \%$ \\
\hline $\begin{array}{r}\text { 8-Identificar a planificação e a representação (em vistas) de } \\
\text { figuras espaciais. }\end{array}$ & $82 \%$ & $17 \%$ \\
\hline $\begin{array}{r}\text { Compreender a relação entre uma fração e a representação decimal } \\
\text { de um número sabendo realizar de modo significativo as } \\
\text { operações de adição, subtração, multiplicação e divisão com decimais. }\end{array}$ & $0 \%$ & $\mathrm{~N} / \mathrm{A}$ \\
\hline $\begin{array}{l}\text { 10-Realizar de modo significativo as operações de adição, } \\
\text { subtração, multiplicação e divisão de números negativos. }\end{array}$ & $14 \%$ & $27 \%$ \\
\hline
\end{tabular}

A organização curricular dos conteúdos básicos envolve números, geometria e relações:

- Os NÚMEROS envolvem as noções de contagem, medida e representação simbólica, tanto de grandezas efetivamente existentes quanto de outras imaginadas a partir das primeiras, incluindo-se a representação algébrica das operações fundamentais sobre elas. Duas ideias fundamentais na constituição da noção de número são as de equivalência e de ordem.

- GEOMETRIA diz respeito diretamente à percepção de formas e de relações entre elementos de figuras planas e espaciais, à construção e à representação de formas geométricas, existentes ou imaginadas, e à elaboração de concepções de espaço que sirvam de suporte para a compreensão do mundo físico que nos cerca.

- As RELAÇÕES, consideradas como um bloco temático, incluem a noção de medida, com a fecundidade e a riqueza da ideia de aproximação, as relações métricas em geral e as relações de interdependência, como as de proporcionalidade ou as associadas à ideia de função. 


\section{Diretrizes de Ensino Integral}

As diretrizes do Programa de Ensino Integral ${ }^{6}$ da escola em questão contêm as informações pertinentes ao seu funcionamento. Para ilustrar, segue um trecho do documento oficial:

"Programa de Ensino Integral, instituído pela Lei Complementar no 1.164, de 4 de janeiro de 2012, alterada pela Lei Complementar no 1.191, de 28 de dezembro de 2012. Esse Programa foi iniciado em 2012, em 16 Escolas de Ensino Médio, e a partir de 2013 expandido para 22 escolas de Ensino Fundamental, Anos Finais e 29 escolas de Ensino Médio, e 2 escolas de Ensino Fundamental e Médio. É uma alternativa para adolescentes e jovens ingressarem numa escola que, ao lado da formação necessária ao pleno desenvolvimento de suas potencialidades, amplia as perspectivas de autorrealização e exercício de uma cidadania autônoma, solidária e competente. O Programa Ensino Integral oferece também aos docentes e equipes técnicas condições diferenciadas de trabalho para, em regime de dedicação plena e integral, consolidar as diretrizes educacionais do novo modelo de escola de tempo integral e sedimentar as possibilidades previstas para sua expansão."

As especificidades encontram-se na Figura 2.5 e ilustram como se dá o funcionamento de uma escola de tempo integral no ensino fundamental.

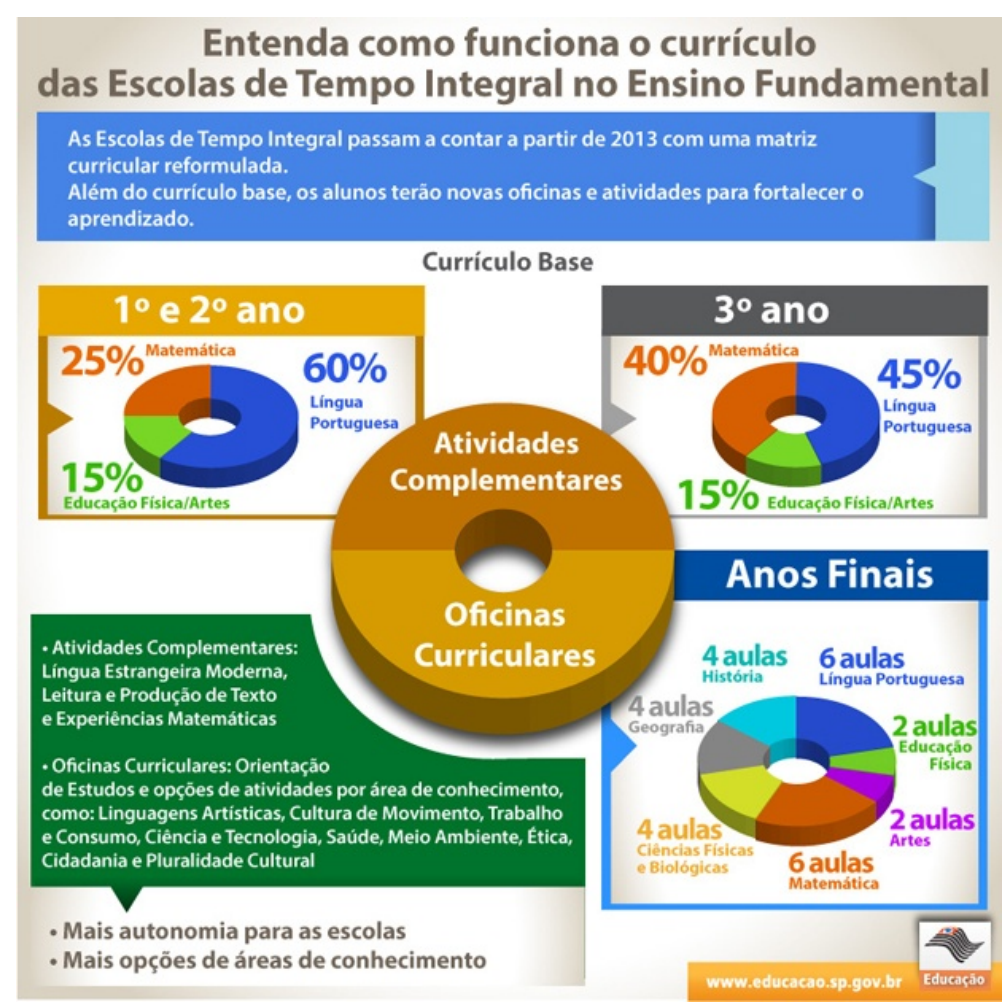

Figura 2.5: Funcionamento da Escola de tempo Integral

Possui um planejamento pedagógico que foi postado no Centro Virtual de Formação Permanente (Moodle) a respeito das intervenções a serem realizadas na escola (Apêndice G).

\footnotetext{
${ }^{6}$ Diretrizes do Programa de Ensino integral, disponíveis respectivamente em: < http://www.educacao.sp.gov.br/ a2sitebox/arquivos/documentos/342.pdf >
} 
A organização e o funcionamento da escola possui alta rotatividade de professores, o que prejudica a continuidade e o desenvolvimento dos projetos. A escola passa o ano letivo todo atendendo demandas burocráticas e dando menor atenção à coordenação pedagógica, que atende às demandas da Diretoria de Ensino pouco presente durante o ano letivo.

As salas de aula são insuficientes para abrigar todos os alunos que precisam ter aulas na sala de Informática, sem o uso dos computadores. Utilizam o refeitório para aulas comuns e para as oficinas à tarde e inexiste o suporte e/ou manutenção da infraestrutura tecnológica. Não há planejamento para o uso dos computadores, em número de 15 unidades, pelos alunos e professores.

\subsection{Estrutura da investigação}

O procedimento desta pesquisa será descrito em ordem cronológica e subdividido em cada passo do ciclo da pesquisa-ação para facilitar o entendimento da coleta de dados e de como se deu sua análise.

\section{Aplicação do primeiro ciclo da pesquisa-ação}

Este trabalho executou os ciclos da pesquisa-ação com uma professora e crianças entre 10 e 15 anos, que participaram por adesão espontânea, seguindo os passos descritos na Figura 2.6, onde as seguintes atividades foram realizadas:

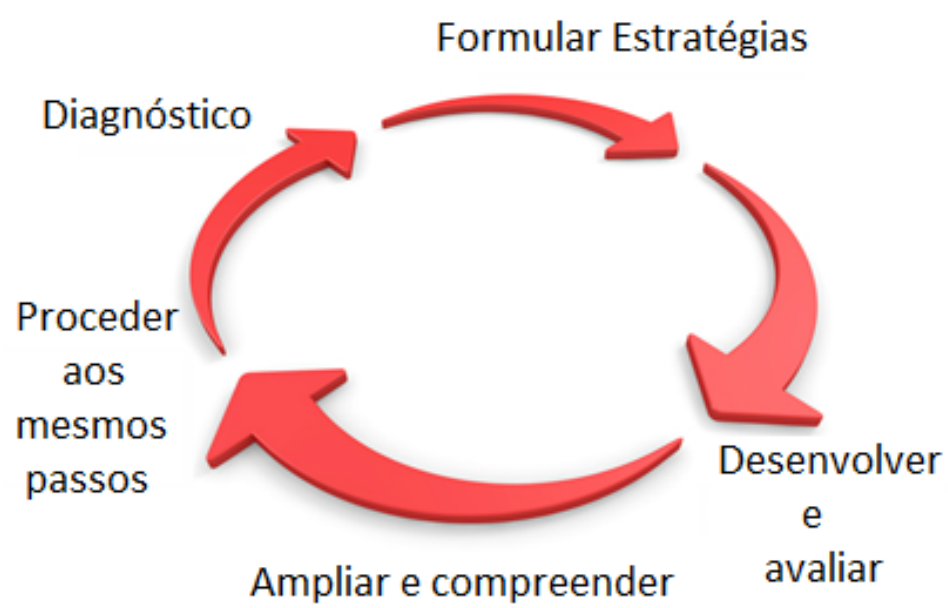

Figura 2.6: Passos executados nos ciclos desta pesquisa

Os alunos foram orientados a jogar o jogo escolhido do dia 21 de outubro de 2015 até o dia 12 de novembro de 2015, data esta escolhida pra execução do grupo focal para a coleta de informações deste experimento. No decorrer desse tempo, o pesquisador visitou a escola uma vez, para conversar com os alunos e professores sobre o andamento das atividades. Os alunos foram assistidos, acompanhados e motivados através da interação facilitada pelo uso de redes sociais como o Whatsapp e o Facebook, além de o mediador jogar junto com os alunos. Um recurso do jogo permitia que o mediador pudesse acompanhar o que estava acontecendo a qualquer momento nas cidades dos jogadores. 


\section{Passo do diagnóstico}

Entrevistas semiestruturadas foram realizadas com $20 \%$ dos alunos de uma turma com sérios problemas de matemática conforme descrito nos Quadros 2.4 e 2.5. Tais entrevistas visaram avaliar a situação e o contexto sociocultural dos alunos para o passo de planejamento. As entrevistas foram feitas nos dias 16 e 18 de setembro de 2015 .

\section{Formular estratégias}

Com posse das informações da escola e dos alunos, foi possível definir um jogo que se adequasse aos perfis dos alunos, como já comentado, identificando suas necessidades e barreiras, possibilitando propor soluções que contornassem a situação crítica. A realidade identificada, onde cada aluno entrevistado alega possuir acesso a tecnologias diversas, primordialmente as tecnologias móveis, direcionou o foco para o uso dos dispositivos como smartphones e tablets, que os pesquisados possuíam, além de promover a escolha do jogo SimCity BuildIt, tal jogo possui de forma implícita e explícita desafios que envolvem questões matemáticas verificadas nos Quadros 2.4 e 2.5.

Com base na hipótese principal desta tese, uma nova hipótese foi formulada para ser testada com esse ciclo, foi: "O jogo digital SimCity BuildIt pode auxiliar o desenvolvimento cognitivo em relação ao currículo escolar de matemática dos alunos, com o auxílio das redes sociais".

Além de testar a hipótese, este ciclo teve como objetivo conhecer os alunos, as possibilidades de trabalho em conjunto e sua aceitação, tanto entre os alunos como entre os professores, e como estes se relacionam com o projeto e a proposta de uso de jogos digitais dentro e fora de sala de aula. Com o que foi desvelado com as experiências deste ciclo da pesquisa-ação, espera-se que no próximo ciclo se possa testar uma hipótese mais conclusiva e menos genérica.

\section{Desenvolver e avaliar}

A aplicação do jogo começou no dia 21 de outubro de 2015. Visitas periódicas de pesquisadores do grupo Alpha foram realizadas durante toda a pesquisa. A coleta de dados envolveu o uso de: i) Diários de campo feitos a cada visita na escola; ii) Grupos nas redes sociais Whatsapp e Facebook, onde dúvidas foram sanadas e houve o compartilhamento de informações entre alunos e professor; iii) Entrevistas individuais; iv) Grupos focais. O pesquisador teve acesso aos jogos de cada jogador conectado ao Facebook. No dia 12 de novembro de 2015 foi realizado um grupo focal para coletar informações sobre a aprendizagem gerada pela experiência do jogo SimCity BuildIt.

A experiência do grupo focal aconteceu ao fim da aplicação do jogo digital, nela o pesquisador responsável colocou no quadro da sala de aula três questões envolvendo a resolução de equações do primeiro grau, contextualizadas com elementos e linguagem presentes no mesmo. Conforme nota-se na transcrição do grupo focal, os alunos resolveram de cabeça a primeira questão, porém foram incentivados a tentar formalizar matematicamente suas respostas usando uma incógnita "X".

Os alunos foram estimulados a explicar o que foi feito no quadro de giz, o que pensaram e como o resolveram, para que ficasse claro para seus colegas. Isso fez com que fosse constatado o entendimento do aluno e como ele chegou à solução apresentada.

No total foram feitas 8 visitas à escola para a mediação do uso de jogos digitais. Em cada visita foram registradas as devidas informações nos diários de campo. 


\section{Ampliar e compreender}

Após a coleta dos dados, obtidos a partir do grupo focal, as reuniões com o grupo Alpha e a análise das transcrições, foi possível chegar a acertos e conclusões que serão trabalhadas no capítulo 5 .

\section{Proceder aos mesmos passos}

No ano de 2016, o responsável por esta pesquisa ajudou a professora da experiência passada a aplicar o experimento com o jogo digital SimCity BuildIt em outra turma, a turma $8^{\circ}$ ano A. Em adição, o experimento foi feito com outros jogos digitais na mesma turma, porém com outra professora, pois a mesma foi designada para outras turmas, agora $9^{\circ}$ ano B. Os jogos testados foram Clash of Clans e The Sims. Dessa forma, iniciou-se dois novos ciclos em paralelo. Em todo momento as professoras foram ouvidas, para ciência de suas necessidades, anseios, dicas e sugestões, objetivando que a aplicação ficasse adequada a sua realidade.

O planejamento com os professores das oficinas de Matemática foi iniciado na escola no dia 2 de dezembro de 2015 para a turma $8^{\circ}$ ano A, no dia 24 de fevereiro de 2016 para a turma $9^{\circ}$ ano B e $7^{\circ}$ ano A. Ao longo da aplicação deste ciclo, o pesquisador visitou a escola para mediar os experimentos com o uso de jogos nas 2 turmas escolhidas. Além disso o pesquisador participou ativamente, jogando em conjunto com os alunos os 2 jogos digitais escolhidos, sempre conversando e compartilhando informações, seja de forma presencial ou pelas redes sociais. Os alunos preferiram e ficaram mais à vontade usando o Whatsapp, notou-se que os mesmos não queriam usar o Facebook.

A análise e a compreensão dos resultados, obtidos durante a aplicação dos jogos digitais nestes ciclos subsequentes, também serão apresentadas no Capítulo 5. Porém, pode-se adiantar que o verificado no ciclo anterior foi reconfirmado neste ciclo, com resultados ainda mais ricos e positivos. Devido à quantidade e à profundidade dos dados, sua análise demandou um capítulo dedicado para este propósito.

\subsection{Sobre os jogos digitais escolhidos}

O jogo digital escolhido para o primeiro ciclo foi o SimCity BuildIt, pois, após analisadas as entrevistas individuais iniciais, encaixava-se no que se pretendia ensinar em Matemática e no perfil de jogador dos estudantes participantes. Após o primeiro ciclo foram escolhidos, em conjunto com os estudantes, o Clash of Clans e o The Sims FreePlay.

\section{SimCity BuildIt}

No SimCity BuildIt a narrativa se dá em uma cidade fictícia, com a estética das cidades dos Estados Unidos, onde o jogador é o prefeito. Os acontecimentos do game se dão de acordo com as decisões e as ações dos jogadores, onde a população fictícia pode elogiar ou reclamar das decisões e suas consequências. Dentro do jogo, alguns funcionários fictícios, como secretário de educação, bombeiros, polícia etc, também podem surgir na tela para explicar ou comunicar um acontecimento do jogo.

SimCity é uma série de jogos de simulação nos quais o jogador constrói e administra uma cidade. As cidades construídas possuem características semelhantes às cidades estadunidenses, em aspectos 
culturais e legais, nos séculos XX e XXI. A série foi criada por Will Wright e publicada pela Maxis (que é atualmente uma divisão da Electronic Arts) ${ }^{7}$.

\section{Clash of Clans}

Clash of Clans é um jogo digital de estratégia do tipo RTS para dispositivos móveis, foi desenvolvido pela Supercell em agosto de 2012 e está disponível para IOS e Android. O mesmo pode ser jogado cooperativamente, colaborativamente e competitivamente.

O jogo digital Clash of Clans contém uma narrativa onde o personagem é líder de uma aldeia campestre ambientada na cultura nórdica. Ao decorrer do jogo, a narrativa é escrita pelo próprio jogador, onde suas ações levam ao estado atual das vilas dos respectivos jogos. O jogador executa atividades como a administração e a extração de recursos voltados para o desenvolvimento bélico militar, de forma a poder executar as guerras de clãs e saques que fazem parte do jogo.

O jogo consiste no desenvolvimento de uma vila para a guerra entre clãs, sem objetivo específico. Contém vários subdesafios que são premiados com moeda especial para a compra de recursos. Os jogadores têm como meta pessoal, ou do grupo, alcançar o maior número de troféus possíveis e chegar ao mais alto nível possível, a fim de chegar ao topo do ranking mundial, individualmente ou cooperativamente, através de clãs. A finalidade das guerras são combater com outros jogadores para roubar recursos e assim desenvolver sua própria vila e, dessa forma, crescer no ranking.

\section{The Sims FreePlay}

The Sims é uma série de jogos eletrônicos de simulação de vida real criada pelo designer de jogos Will Wright e distribuída pela empresa Maxis. O primeiro jogo da série foi lançado em 4 de fevereiro de 2000. O jogador cria e controla a vida de pessoas virtuais chamadas de Sims, incluindo a administração financeira dos avatares e a busca de emprego, ou a prática de atividades que, de alguma forma, podem gerar renda. O dinheiro obtido serve para, entre outras coisas, comprar comida e objetos para o lar, bem como para reformar a casa ou efetuar a compra de uma casa maior, ou ainda a compra de um lote vazio para construir uma casa do princípio. O jogo envolve relações socioemocionais entre avatares, podendo ser jogado no modo multiplayer, onde avatares podem visitar as casas de outros jogadores online. É possível, por exemplo, morar junto, casar e ter filhos.

O jogo digital The Sims FreePlay tem sua narrativa ambientada em torno de famílias, onde o jogador tem que criar avatares e cuidar deles, como a simulação de uma vida real, gerenciando ações - como comer, trabalhar, comprar coisas para casa, estudar - e desenvolvendo habilidades diversas - como plantar, cozinhar, tocar violão etc. Pode-se também fazer o gerenciamento social dos personagens, como fazer amizade, namorar, casar, ter filhos etc. O jogador que controla a narrativa, de acordo com suas ações, decisões e suas respectivas consequências. Os avatares não possuem autonomia, o jogador precisa controlar e mandar fazer as ações desde as básicas - como ir ao banheiro, comer etc. - até as mais complexas - como estudar, desenvolver habilidades e procurar emprego.

O jogo atraiu legiões de fãs devido a sua simplicidade e objetividade. Os jogos foram portados e convertidos para diversas plataformas, incluindo Nintendo Wii, computador, celular, Nintendo DS,

\footnotetext{
${ }^{7}$ SimCity, Disponível em: <http://www.simcity.com/>
} 
Playstation 2, GameBoy Advance, GameCube, Android, iOS, Xbox, entre outros. 


\section{Capítulo 3}

\section{Revisão da Literatura}

Este capítulo trata do mapeamento realizado para o conhecimento das produções acadêmicas sobre o tema. É extensa a produção internacional sobre o tema da presente investigação, contudo a produção científica brasileira voltada ao desenvolvimento e à aplicação de jogos digitais ligados à educação e à aprendizagem ainda é reduzida. São limitados os estudos relacionados ao desenvolvimento cognitivo por meio de jogos digitais das competências contidas no currículo escolar brasileiro.

\subsection{Produção nacional}

Cabe destaque à produção de Lourenço (2012), sobre o estado de conhecimento a respeito dos games, a partir do banco de teses e dissertações da CAPES, entre os anos de 1987 e 2010. O principal objetivo foi mapear e discutir a produção acadêmica brasileira, com o tema central ligado aos recursos tecnológicos, em seu estatuto comunicacional, lúdico e educacional. A problematização da pesquisa propôs a discussão sobre a forma com que os jogos digitais são entendidos nas práticas educacionais e o estudo dos meios de comunicação na sua mediação tecnológica com os distintos setores do conhecimento.

Também o estudo de Jappur (2014) executou uma pesquisa bibliométrica, até 2014, para propor um modelo conceitual de desenvolvimento, avaliação e aplicação de jogos educativos digitais para o contexto do processo de ensino e aprendizagem em sala de aula. Em sua pesquisa, fez uma extensiva revisão sistemática em busca de trabalhos nacionais e internacionais que relacionassem jogos digitais ao ensino e aprendizagem.

Especificamente para a presente investigação, foi definido um recorte temporal utilizado para o mapeamento das produções e seu devido tratamento metodológico. Um documento da UNESCO (2014), que contém as diretrizes de utilização de dispositivos móveis em escolas, lançado em 2013, constituiu o marco para o recorte temporal, que justifica-se por seus objetivos de contribuir com a formação docente. A pesquisa dos trabalhos foi realizada em bases nacionais e internacionais, que levaram em consideração o contexto educacional, cultural e social. Tal contextualização é fundamental para definir e estruturar aplicações pedagógicas adequadas às necessidades dos docentes e dos discentes envolvidos (Freire, 2006).

De 2013 a 2016 foram verificados, na plataforma do Instituto Brasileiro de Informação em Ciência e Tecnologia (IBICT) ${ }^{1}$, apenas dezessete trabalhos na área de jogos digitais no contexto de

\footnotetext{
${ }^{1}$ Instituto Brasileiro de Informação em Ciência e Tecnologia (IBICT), órgão nacional de informação, unidade de pesquisa do Ministério da Ciência, Tecnologia e Inovação (MCTI). Realiza estudos no campo da ciência da informação
} 
ensino e aprendizagem, sendo treze dissertações e quatro teses, conforme apresentado no Quadro 3.1 abaixo. Foram utilizados os seguintes critérios: ano, autor(es), título, modalidade de produção, teóricos de fundamentação teórica das produções e origem dos trabalhos (instituições).

Lealdino Filho (2014) investigou elementos para o desenvolvimento de jogos digitais educativos, buscando uma relação clara com teorias de ensino-aprendizagem e aplicando técnicas de engenharia de software. O objetivo da pesquisa foi aferir a motivação conseguida por um jogo educativo de Matemática, As aventuras de Simon Bile, implementado dentro da dissertação. Depois de um teste inicial, durante o desenvolvimento do jogo, uma pesquisa experimental foi conduzida com uma amostra de 50 alunos divididos em dois grupos, de controle e experimental. Utilizou-se, como instrumento, um questionário demográfico e um questionário de motivação. A análise de dados proposta por Lealdino Filho (2014) indicou resultados favoráveis ao jogo construído (jogo sobre problemas matemáticos), uma vez que este mostrou-se motivador para os alunos e fez com eles dedicassem tempo para jogá-lo.

A pesquisa de Trois (2013) teve por objetivo desenvolver e avaliar um conjunto de heurísticas projetuais que possam contribuir com o desenvolvimento, a adaptação de conteúdo instrucional e a avaliação de jogos digitais educativos. Para isso, foram investigados aspectos relativos ao design instrucional e abordagens de aprendizagem, bem como características referentes a elementos que constituem os jogos digitais comerciais. Esses dados, obtidos a partir de base teórica composta por autores diversos, foram analisados e comparados a partir de informações similares e/ou complementares, gerando um conjunto inicial de heurísticas. Essa produção foi revisada e incrementada com informações obtidas por meio de entrevistas com especialistas da área, realizadas para compreender as percepções e os aspectos relacionados à prática do desenvolvimento de jogos educativos. $\mathrm{O}$ conjunto de heurísticas foi, então, testado e avaliado por especialistas e readequado conforme o feedback recebido. Os resultados permitiram a construção de um protótipo funcional para a adaptação de conteúdo instrucional, o desenvolvimento e a avaliação de jogos digitais educativos.

O trabalho de Menezes (2013) está relacionado ao uso de jogos sociais digitais para a aprendizagem de língua inglesa. O objetivo dessa pesquisa consistiu em investigar e compreender como ocorre o interesse, bem como a aceitação, do uso de um jogo como entretenimento para fins de aprendizagem, a análise das possibilidades de sintonia entre o jogo e o conteúdo programático da aula presencial de língua inglesa, a análise de como os participantes colaboram entre si durante o jogo e como essa colaboração contribui para a aprendizagem e a análise e compreensão de como as interações dos participantes com o jogo podem favorecer o desenvolvimento da competência comunicativa na aprendizagem da segunda língua. Para essa pesquisa, foram utilizados dois jogos sociais digitais, The Sims Social e Wetopia, presentes no Facebook, com dois grupos de alunos de língua inglesa. A pesquisa teve enfoque qualitativo, de natureza exploratória e utilizou a metodologia de estudo de caso. Os dados foram coletados por meio das interações entre os participantes durante o jogo, registradas em chats e no mural dos grupos criado no Facebook, e também em entrevistas semiestruturadas após o experimento. Como resultados da pesquisa, salienta-se que os jogos sociais digitais, presentes no contexto de uma mídia social digital, possibilitaram um ambiente para o ensino e a aprendizagem de língua inglesa, favorecendo o desenvolvimento de competência comunicativa, permitindo a sintonia entre a sala de aula presencial e o contexto do jogo, engajando os participantes em atividades colaborativas e gerando interesse pela sua aprendizagem com e através 
Quadro 3.1: Produções - IBICT - (2013-2016)

\begin{tabular}{|c|c|c|c|}
\hline $\begin{array}{c}\text { Citação/ } \\
\text { Título }\end{array}$ & $\begin{array}{l}\text { Fundamento } \\
\text { Teórico }\end{array}$ & Tipo de produção & Universidade \\
\hline $\begin{array}{l}\text { Lealdino Filho (2014) Jogo digital } \\
\text { educativo para o ensino de matemática }\end{array}$ & Vygotstky & Dissertação & UTFPR \\
\hline $\begin{array}{r}\text { Trois (2013) Proposta de heurísticas } \\
\text { para adaptação de conteúdo } \\
\text { instrucional a games educativos }\end{array}$ & Campos & Dissertação & UFRGS \\
\hline $\begin{array}{r}\text { Jappur (2014) Modelo conceitual } \\
\text { para criação, aplicação e avaliação } \\
\text { de jogos educativos digitais }\end{array}$ & Piaget & Dissertação & UNISINOS \\
\hline $\begin{array}{r}\text { Menezes (2013) Jogos sociais digitais } \\
\text { como ambiente de aprendizagem } \\
\text { da língua inglesa }\end{array}$ & Piaget / Vigotstky & Dissertação & UFRN \\
\hline $\begin{array}{r}\text { Soares (2013) A aprendizagem } \\
\text { de inglês mediada por jogos } \\
\text { eletrônicos do tipo MMORPG }\end{array}$ & Piaget / Vigotstky & Dissertação & UNB \\
\hline $\begin{array}{r}\text { Silva (2014) Formação lúdica } \\
\text { do futuro professor de matemática } \\
\text { por meio do laboratório de ensino }\end{array}$ & Vigotsky & Tese & UFSC \\
\hline $\begin{array}{r}\text { Marques (2014) Estudo de inserção } \\
\text { de jogos computadorizados como } \\
\text { recurso complementar ao ensino } \\
\text { de leitura }\end{array}$ & Skinner & Tese & UFSCar \\
\hline $\begin{array}{r}\text { Maziviero (2014) Jogos digitais } \\
\text { no ensino de matemática: o } \\
\text { desenvolvimento de um instrumento } \\
\text { de apoio ao diagnóstico } \\
\text { das concepções dos alunos sobre } \\
\text { diferentes representações dos números }\end{array}$ & Piaget & Dissertação & UNESP \\
\hline $\begin{array}{r}\text { Braghirolli (2014) Aprendizagem por } \\
\text { jogo computacional na engenharia } \\
\text { de produção }\end{array}$ & Pozo & Tese & UFRGS \\
\hline $\begin{array}{r}\text { Ignácio (2013) O RPG eletrônico } \\
\text { no ensino de química: uma } \\
\text { atividade lúdica aplicada ao } \\
\text { conhecimento de tabela periódica }\end{array}$ & Piaget & Dissertação & UTFPR \\
\hline $\begin{array}{r}\text { Buchinger (2014) Sherlock dengue } 8: \\
\text { the Neighborhood - um jogo } \\
\text { sério colaborativo-competitivo } \\
\text { para combate à dengue }\end{array}$ & JOHNSON e JOHNSON & Dissertação & UDESC \\
\hline $\begin{array}{r}\text { Câmara (2014) Motivação e games: } \\
\text { o uso do jogo Angry Birds com } \\
\text { estudantes para o ensino de física }\end{array}$ & Piaget / Vigotstky & Dissertação & UFPE \\
\hline $\begin{array}{r}\text { Antônio (2014) Jogos digitais } \\
\text { e a mediação do conhecimento na } \\
\text { perspectiva da psicologia } \\
\text { histórico-cultural }\end{array}$ & Vygotstky & Dissertação & USP \\
\hline $\begin{array}{l}\text { Santos (2014) Interpretando "mundos": } \\
\text { jogos digitais \& aprendizagem histórica }\end{array}$ & Greenfield & Dissertação & UFU \\
\hline $\begin{array}{r}\text { Pinto (2014) Educação com } \\
\text { entretenimento: um experimento com } \\
\text { SimCity® para curtir e aprender } \\
\text { contabilidade governamental }\end{array}$ & Kolb & Tese & USP \\
\hline $\begin{array}{r}\text { Santos }(2015) \text { Qualidade dos } \\
\text { jogos que influenciam positivamente } \\
\text { o processo de aprendizado: } \\
\text { uma análise crítica }\end{array}$ & Piaget & Dissertação & UFPE \\
\hline
\end{tabular}

dos jogos.

O que se propõe no estudo de Soares (2013) é um maior conhecimento sobre a aprendizagem 
de língua inglesa mediada por jogo MMORPG, para que os professores saibam como apresentar, utilizar ou incentivar essa prática junto a seus alunos. Com base neste objetivo principal, o autor procurou responder as seguintes perguntas da pesquisa: (a) O que distingue o perfil de exposição à língua inglesa dos jogadores e não-jogadores; (b) O MMORPG pode, por meio de uma prática híbrida e sistemática, auxiliar no desenvolvimento da proficiência na língua adicional? e (c) O que os protocolos think-aloud evidenciam acerca da aprendizagem mediada pelo MMORPG Allods Online? O experimento envolveu dezesseis alunos do componente curricular Práticas de Leitura e Produção Escrita em Língua Inglesa, no qual fizeram parte do grupo de controle. Dezessete alunos da mesma turma compuseram o grupo experimental e foram submetidos a um pré e pós-teste. Os testes foram administrados antes e depois de um período de 5 semanas, com 3 horas por semana, de experimento com o jogo Allods Online (grupo experimental) e de aulas do componente curricular (ambos os grupos). Uma análise quantitativa dos questionários sobre os perfis de exposição à língua inglesa dos participantes, uma análise quantitativa das notas dos testes e uma análise qualitativa de protocolos think-aloud, coletados durante o experimento, foram feitas. Segundo o autor, os resultados indicaram que os participantes do grupo experimental de jogadores pareceram ser mais engajados em atividades tangenciais de aprendizagem de língua inglesa, como jogar games, ouvir música em inglês, comunicar-se com estrangeiros e ler em inglês. Também concluiu que o período de experimento pode ter gerado resultados positivos nas notas dos testes dos alunos que jogaram, principalmente nas partes relacionadas: (a) Ao desenvolvimento ortográfico, leitura e interpretação; (b) À escrita com foco no conteúdo e (c) À acurácia ortográfica. Por fim, os protocolos think-aloud apresentam evidências de que os jogadores engajaram-se na aprendizagem ativa de língua inglesa, interagiram em inglês com outros jogadores e aprenderam aspectos linguísticos através da experiência com o MMORPG Allods Online.

A pesquisa de Silva (2014) analisou como um grupo de estudantes do curso de Licenciatura em Matemática da Universidade do Estado da Bahia, Campus IX, a formação lúdica realizada na disciplina Laboratório do Ensino da Matemática I. O autor Silva (2014) relata que essa pesquisa foi motivada pelos questionamentos: por que, mesmo sabendo da importância e contribuição do lúdico, há resistência por parte de muitos professores em utilizá-lo? Há necessidade de uma formação lúdica para o professor? Como posso abordar a dimensão lúdica no processo de formação inicial do professor de Matemática? Como o trabalho com a disciplina de Laboratório do Ensino da Matemática I pode contribuir nesse sentido? Trata-se de uma pesquisa que seguiu a metodologia pesquisa-ação. Questionários iniciais, finais e observação participada foram utilizados como instrumentos de coleta de dados.

Marques (2014) utilizou jogos educacionais para investigar métodos de avaliação da influência de jogos eletrônicos educacionais na aprendizagem de leitura. Foram propostos dois estudos complementares: o estudo 1 testou a aplicação em larga escala de um software e do procedimento de leitura em um ambiente escolar com 11 participantes; o estudo 2 incorporou esse mesmo procedimento de ensino em um jogo e avaliou a preferência entre o jogo e a condição de ensino sem jogo dentre 27 alunos do ensino fundamental. Os resultados indicaram que nos dois estudos as duas condições de aplicação do programa de ensino foram efetivas no ensino das habilidades básicas de leitura. Discreta maioria dos participantes apresentaram preferência pela condição de ensino no formato de jogo e os ganhos nos desempenhos de leitura foram mantidos nessa condição. O número de repetições do procedimento de ensino para que a aprendizagem ocorresse também foi menor na 
situação de jogo. Não foi possível identificar preferência entre jogo ou o procedimento convencional para cerca de 30\% dos participantes. Esses participantes alternaram entre as duas condições e seus resultados na aquisição da leitura não diferem dos que trabalharam preferencialmente em uma das condições (apenas jogo ou apenas procedimento padrão, sem jogo). Os participantes que apresentaram preferência pela condição com jogo tenderam a repetir menos blocos de treino utilizados como componentes de cada sessão de ensino. Uma tarefa de escolha entre a condição padrão e o retorno à sala de aula indicou que os participantes com preferência pela condição com jogo mantiveramse engajados no procedimento de ensino quando dada a oportunidade de retornar à sala de aula. A discussão focalizou-se nos parâmetros utilizados na tarefa de escolha, apontando manipulações que otimizassem o método para medir a preferência, com a finalidade de torná-lo mais sensível a diferentes medidas do jogo como fator motivacional.

No trabalho de Maziviero (2014) foi realizada uma revisão de literatura sobre game design para o desenvolvimento de um jogo digital com características de motivação, imersão e conhecimento. O jogo foi baseado nas teorias do game design, com tecnologias específicas, de modo que o jogo fosse acessível em dispositivos variados e com diferentes tipos de sistemas operacionais. O jogo contemplou três elementos básicos: a interface do aluno, composta por elementos jogáveis; a interface do professor, composta por elementos de análise em tempo real; e o servidor de transmissão e armazenamento dos dados. O jogo foi aplicado para seis alunos de uma turma de nono ano em uma escola estadual do município de Jaboticabal. Optou-se pela interpretação dos dados por meio de abordagens qualitativas. Os resultados indicam que o jogo digital proposto gera informações suficientes para que o professor identifique as características de seus alunos em relação a conteúdos de matemática, melhorando seu processo de ensino.

Braghirolli (2014) fez uso de jogos educacionais para suplantar dificuldades como: a fragmentação do conhecimento, a desmotivação dos alunos e a crescente demanda pelo ensino de nível superior. A partir da concepção de que a capacidade de integração de conhecimentos deve ser trabalhada desde o início da formação dos alunos, foi proposto o uso de jogos educacionais no contexto do primeiro ano do curso de graduação em Engenharia de Produção. Essa proposição visou a utilização do potencial dos jogos em situações complexas, sem desmotivar os jogadores, permitindo introduzir os alunos ingressantes no contexto de atuação desse profissional, sem desmotivá-los. Ainda, tal proposta explora o potencial de utilizar os jogos como fonte de informação sobre a aprendizagem dos alunos, auxiliando o docente na identificação de eventuais dificuldades. Com base na utilização desse jogo em turmas de primeiro ano, avaliou-se por meio de questionário a contribuição do jogo proposto para a aprendizagem e a motivação dos alunos. Também se avaliou a receptividade dos alunos para o uso de jogos educacionais. O potencial de uso dos dados coletados pelo jogo no auxílio ao docente foi avaliado com base na análise desses dados. Como resultado, foi observado que os jogos educacionais: retiram o foco do professor, dando-lhe liberdade para interagir de forma individualizada com os alunos; são capazes de promover aprendizagem e motivar; possuem boa aceitação por parte dos alunos, sendo a percepção de satisfação proporcionada pelos jogos fator preponderante à percepção de utilidade; possuem informações úteis sobre a aprendizagem nos dados coletados durante a interação com os alunos. Assim, concluiu-se que o uso de jogos educacionais como atividade introdutória no ensino superior de Engenharia de Produção é uma alternativa que agrupa importantes benefícios.

Ignácio (2013) utilizou a tabela periódica com o intuito de criar um jogo eletrônico, no estilo 
RPG, elaborado de acordo com conteúdos relacionados ao conhecimento da tabela. O jogo teve como material de consulta o diagrama de Linus Pauling e foi sugerido que o aluno utilizasse a tabela periódica enquanto jogasse. A associação da tecnologia à atividade lúdica contribuiu no desenvolvimento do jogo de RPG eletrônico que, segundo os resultados, auxiliou no processo de ensino e aprendizagem da tabela periódica, devido aos seus desafios e propostas que motivaram e despertaram o interesse do aluno.

Buchinger (2014) projetou e desenvolveu um jogo digital sobre dengue, com a característica de ser colaborativo-competitivo, como meio de aumentar a motivação e trazer maior aprendizado. Como foi encontrada uma metodologia de design, adotaram-se os fundamentos da área motivacional de jogos para orientá-lo. O jogo foi promovido e utilizado por diversos públicos, do ensino fundamental à pós-graduação, em mutirões de conscientização sobre a dengue. A fim de avaliar a aprendizagem com a utilização do jogo, 71 participantes responderam a um questionário de conhecimento e confiança antes e após o uso do jogo. Com base nos dados obtidos foi verificado um aumento médio de 17,35\% no conhecimento sobre dengue, um aumento médio de $51,23 \%$ na confiança das respostas e um aumento de $74,07 \%$ no número de participantes que obtiveram nota igual ou superior a sete, numa escala de zero a dez. O autor afirma, com base nos resultados, que são fortes os indícios de que o Sherlock Dengue 8 pode promover aprendizado e confiança no conhecimento sobre a dengue.

Na pesquisa de Câmara (2014), embasada na Teoria de Metas de Realização, foram apontados dois tipos de metas: aprender e performance. A meta aprender é associada ao bom desempenho, à manutenção da atenção e ao interesse em sala de aula; a meta performance pode ser associada a aspectos positivos ,como persistência e esforço (meta performance aproximação), e a aspectos negativos, como medo do fracasso e ansiedade (meta performance evitação). Entendendo a importância dos jogos como estimuladores do desenvolvimento dos indivíduos e como meio para motivar o aluno, facilitando a aprendizagem, esse estudo investigou a possibilidade da utilização do jogo Angry Birds como meio para motivar os alunos pelo processo de ensino-aprendizagem da disciplina de Física. Assim, participaram dessa pesquisa 21 alunos do nono ano de uma escola pública de João Pessoa. O método consistiu na elaboração de aulas em que houvesse a união dos conteúdos programáticos da disciplina e do jogo. Posteriormente, foi aplicada a Escala de Motivação para Aprendizagem (EMAPRE), com o intuito de verificar a motivação discente. As aulas foram ministradas a partir das relações entre o jogo e os conteúdos, favorecendo momentos em que os alunos pudessem construir e verificar seus conhecimentos jogando o Angry Birds. Por fim, houve a reaplicação da EMAPRE com o intuito de verificar a motivação dos alunos após as aulas. Os resultados quantitativos apontaram aumento significativo na motivação dos estudantes e diminuição do comportamento de evitação em sala de aula. Os resultados demonstraram um aumento do interesse discente pelas aulas e pelo processo de aprendizagem, apontando maior motivação para este processo. Os resultados positivos demonstraram a necessidade de um maior interesse dos educadores pela inclusão dos jogos eletrônicos na escola, pois é uma possibilidade de aproximar o ensino ao contexto dos discentes, tornando a educação algo interessante, desafiador e prazeroso.

Antônio (2014) abordou questões relacionadas aos impactos que os games trazem à educação na infância: inquietações de pais e professores sobre a influência desses jogos sobre as crianças; como se dão as relações entre essas crianças e entre elas e o conhecimento, mediadas pelos jogos digitais; e como a mediação durante as sessões de jogos digitais pode proporcionar aprendizagem e ampliação do conhecimento. Teve como objetivo investigar o papel dos jogos digitais e a mediação 
do conhecimento em espaços não formais de educação. Este trabalho teve como base referencial a psicologia histórico-cultural. A pesquisa de campo foi realizada durante o ano de 2012, por meio da metodologia qualitativa, com inspirações na etnografia, sendo o principal instrumento de coleta de dados a observação participante. Foram envolvidas neste trabalho as crianças do primeiro ano do ensino fundamental da Escola de Aplicação da FEUSP, as professoras responsáveis pelas turmas e o próprio pesquisador, durante os momentos de atividades lúdicas nas dependências do Laboratório de Brinquedos e Materiais Pedagógicos (LABRIMP). Enquanto grupos de crianças utilizavam os computadores e os jogos digitais, observou-se a ocorrência de atividade mediada dos sujeitos, os instrumentos e os signos. Os dados coletados consistiram em registros de vídeo das crianças durante o jogo, das vozes dessas crianças, de entrevistas e conversas com as professoras e anotações no diário de campo. Esses dados foram organizados e analisados por meio de triangulação. Ao final foi possível verificar a incidência das modalidades de mediação que são mais efetivas para propiciar a cultura lúdica e, ao mesmo tempo, a ampliação da experiência da criança.

A pesquisa de Santos (2014) objetivou investigar, sob abordagem qualitativa, as possibilidades de aprendizagem histórica mediada pelos jogos digitais. Com a pretensão de abranger reflexões sobre as possibilidades que os jogos digitais exercem na produção da interpretação feita pelos jogadores, essa interpretação é apreendida nesse trabalho pelo viés da aprendizagem em História, ou seja, interpretação como exercício cognitivo. Os instrumentos usados para a coleta de dados foram: questionários, observação e entrevistas, sendo que esses instrumentos levantaram informações sobre os jovens e suas relações com os videogames. Buscou-se compreender a juventude para além dos estereótipos socialmente hierarquizados, entendendo-a como fase da vida em si, e não apenas momento intermediário entre a infância e a fase adulta. A respeito da aprendizagem, esta foi abordada pela perspectiva histórico-cultural, o que deu oportunidade para o pensamento da aprendizagem como produto das relações sociais, de tal forma que aprender faz parte de uma dimensão integral da prática social. A propósito do aprendizado em História, foi empregada como tese a ideia de que este não é algo inato do ser humano, pelo contrário, houve um entendimento de que há necessidade de estímulos externos para se aprender História. Quando foram abordados os jogos digitais e a aprendizagem, compartilhou-se da ideia que os videogames não são apenas objetos de passatempo, ao invés disso, são objetos da cultura que precisam ser investigados para que se possa compreender as relações junto ao jogador. Também foi discutida nesse trabalho a interpretação em História, que deve ser entendida como integrante das manifestações cognitivas, e essas são importantes no trabalho de pensar historicamente. Por fim, o trabalho revelou que os jogos digitais de temática histórica são objetos da cultura capazes de mediar situações que levam os jogadores a pensar e interpretar situações e representações que sugerem épocas passadas, assim, a relação temporal foi fator relevante para que os jovens interpretassem sentidos históricos nas imagens mediadas pelo game. No entanto, o autor afirma que há necessidade de aprofundar o debate na escola sobre a História e os meios midiáticos, a fim de oferecer aos sujeitos operações mentais mais críticas sobre a relação da História com as representações da tela.

Pinto (2014) objetivou, em seu trabalho, a análise dos efeitos do emprego do jogo SimCity nas atividades educacionais no nível de graduação, bem como sua contribuição para a composição de um ambiente que promova o aumento nos níveis de motivação e de desempenho no processo de aprendizagem. Tal trabalho buscou evidências sobre os reflexos do emprego do jogo eletrônico SimCity na execução das atividades instrucionais realizadas na disciplina de Contabilidade Governamental. 
Para tanto, foi utilizado o método quase experimental, com a formação de um grupo experimental e outro de controle. As diferenças, referentes aos níveis de desempenho, foram coletadas por meio de uma observação inicial (pré-teste) e de uma observação final (pós-teste). Da população acessível da pesquisa, foi extraída uma amostra com dados que foram expostos aos testes estatísticos paramétricos. Já em relação à variável qualitativa de motivação, apresentou-se medidas baseadas em resultados parciais referentes às dimensões da atenção, relevância, confiança e satisfação. As conclusões indicam a existência de efeitos positivos da aplicação dos jogos eletrônicos na constituição de ambientes instrucionais, quando realizadas comparações com os resultados alcançados com a aplicação de técnicas convencionais na execução dos processos instrucionais.

O trabalho de Santos (2015) teve por objetivo analisar as características dos jogos que visam tornar o modelo de ensino mais eficaz, demonstrando suas qualidades mais importantes e como elas podem ser utilizadas para tornar o aprendizado mais atraente e envolvente para os alunos.

Uma vez analisado o cenário nacional, voltou-se para o cenário internacional. Um artigo contendo uma revisão sistemática foi encontrado em um periódico por meio do Google Acadêmico, analisando trabalhos sobre uso de jogos digitais no ensino, do ano 2000 até 2012 (Clark et al., 2016).

A pesquisa de Tabuti e Nakamura (2015) realizou uma revisão sistemática com o propósito de identificar e entender os métodos existentes para o desenvolvimento de jogos digitais de lógica em dispositivos móveis qualificados para a educação. A revisão mostrou que estudos que utilizam ou definem métodos deste tipo ainda não foram explorados na literatura.

O uso dos jogos digitais em dispositivos móveis pelos alunos tem representado interessante etapa nas atividades de interação humano-computador. Eles envolvem vários tipos de tecnologias processadas por interfaces touchscreens, ondas acústicas e habilidades óticas, entre outros recursos. Muitas pesquisas têm avançado em seus designs progressivamente, aperfeiçoando ainda mais os ambientes interativos (Brom et al., 2011; Dietz e Leigh, 2001; Hwang e Su, 2012; Wilson, 2004).

Estudos de Lave e Wenger (1991) e Pachler (2009) descreveram que a tradução literal da expressão latina in situ significa "na posição", que representa uma exposição sobre a aprendizagem baseada em localização. Afirmaram que:

"Na aprendizagem baseada em localização, os jogadores devem estar em mesma localidade espacial, a fim de compartilhar informações e agir juntos" (p. 721).

No entanto, a aprendizagem in situ não poderia articular totalmente a ideia central da contextualização, o que caracteriza a natureza da abordagem mobile lerning. Os pesquisadores afirmaram que:

"A aprendizagem é como uma atividade situada e concebida do aluno, de suas atividades e do mundo, como mutuamente constitutivas [...] Aqui, a aprendizagem é recíproca, reflexiva e coletiva" (p. 29).

Tal postura, conhecida como abordagem de aprendizagem situada, reflete a noção de estudo sobre mobile learning que reitera que o foco deveria estar em contextos, geração e contexto de travessia (Pachler, 2009). Definiram um contexto móvel como:

"trabalho semiótico e produção de significados que podem ser desenvolvidos pelos alunos, com a ajuda de dispositivos móveis, novas práticas culturais com e através do que eles aprendem. A aprendizagem situada favorece o reforço dos seus recursos no sentido de interagir com o mundo" (p. 5). 
O estudo em contexto de aprendizagem móvel de Tan e So (2015) destacou que a configuração contextual não pode permanecer constante:

"como a ação se desenrola onde novos campos semióticos podem ser adicionados, enquanto outros são tratados como irrelevantes" (p. 21).

As ações e processos de pensamento experimentam um curso de mudança contínua como novos recursos semióticos do contexto. Como tal, os participantes alteraram seu curso de ações para acomodar, para se adaptar às novas realidades e/ou para seu realinhamento.

Ainda segundo o estudo de Pachler (2009), da mesma forma e sobre o tema em questão, a natureza fluida e imprevisível de contexto da aprendizagem móvel, a pesquisa reafirmou que tal fato:

"torna-se uma propriedade e continuamente se desdobra nas interações entre as pessoas e seus objetivos, definições e tecnologias. Contexto não pode ser facilmente previsto em termos de avanços pré-determinados, mas pode ocorrer a qualquer minuto pelo celular dos alunos e seus dispositivos" (p. 159).

Outros estudos que teorizaram sobre mobile learning (Orion e Hofstein, 1994; Sharples et al., 2002) reiteraram que a diferença essencial em relação à aprendizagem móvel é o fato de que o aluno é móvel, pois aprende no local onde se encontra. Sustentaram preocupação fundamental relativa à compreensão da essência da aprendizagem móvel para compreender como as pessoas se envolvem com os seus arredores para criar sites ou redes sociais de improviso para aprender.

\subsection{Produção internacional}

Do ano de 2013 até 2016, executou-se uma busca exploratória no Google Acadêmico sobre trabalhos referenciados com os descritores: game-based learning; digital games e comercial games, tendo como foco a procura de aplicações de jogos comerciais para o ensino. O Quadro 3.2 abaixo contém os trabalhos encontrados e quatro deles não fundamentaram suas pesquisas.

Dos trabalhos internacionais, Sundqvist (2013) usou game do tipo MMORPG, para ensino da língua inglesa para suecos. No jogo digital foram explorados fatores sociais, uma vez que os MMORPG necessitam de interações sociais durante a experiência de jogo. Os resultados da experiência demonstraram que os jogadores se saíram melhor nos testes de vocabulário.

O trabalho de Razak e Connolly (2013) foi sobre aprendizado interdisciplinar de conhecimentos gerais com crianças da escola primária. Um dos temas abordados foram as Olimpíadas. Um dos jogos utilizados foi o Mario \& Sonic Olympic Games, do console Nintendo Wii. Os resultados foram comparados com os obtidos em uma metodologia tradicional de ensino. Os temas trabalhados foram relacionados ao currículo escolar da Escócia. Os resultados foram considerados, pelo autor, como relevantes para o desenvolvimento do ensino por jogos digitais. Um dos resultados apontados indicam que tal aprendizado foi mais interessante e relevante para a jovem geração.

Já no trabalho de Bing (2013) o tema trabalhado foi o aprendizado de narrativa e interpretação. O estudo notou que diversos elementos das narrativas dos jogos digitais difere das narrativas encontradas nas escolas dos EUA. O estudo aponta que essas características encontradas podem 
Quadro 3.2: Google Acadêmico - (2013 ? 2016)

\begin{tabular}{|c|c|c|c|}
\hline $\begin{array}{l}\text { Citação/ } \\
\text { Título }\end{array}$ & $\begin{array}{l}\text { Fundamento } \\
\text { Teórico }\end{array}$ & Tipo de produção & Universidade \\
\hline $\begin{array}{r}\text { Sundqvist (2013)Categorization of digital } \\
\text { games in English language learning studies: } \\
\text { Introducing the SSI Model }\end{array}$ & Vygotstky & Artigo & Karlstad University \\
\hline $\begin{array}{r}\text { Razak e Connolly (2013) Using games as } \\
\text { a context for interdisciplinary learning: } \\
\text { A case study at a Scottish } \\
\text { primary school }\end{array}$ & Malone & Artigo & University of the West of Scotland \\
\hline $\begin{array}{r}\text { Bing (2013) Enhancing narrative } \\
\text { writing skills through } \\
\text { action-adventure video games }\end{array}$ & Roger & Artigo & Universiti Teknologi Malaysia \\
\hline $\begin{array}{r}\text { Söbke et al. } \begin{array}{l}\text { (2013) Using the master } \\
\text { copy-adding educational }\end{array} \\
\text { content to commercial video games }\end{array}$ & - & Artigo & Bauhaus-Universität Weimar \\
\hline $\begin{array}{r}\text { Shahriarpour et al. (2014) On the effect of } \\
\text { playing digital games on Iranian } \\
\text { intermediate EFL learners? motivation } \\
\text { toward learning English vocabularies }\end{array}$ & - & Artigo & Islamic Azad University \\
\hline $\begin{array}{r}\text { Avraamidou et al. (2015b) Mathematics } \\
\text { and Non-School Gameplay }\end{array}$ & Vygotstky & Cap. de Livro & University of Leeds \\
\hline $\begin{array}{r}\text { Beavis (2015) Multimodal literacy, } \\
\text { digital games and curriculum }\end{array}$ & - & Cap. de Livro & Grifftih University \\
\hline $\begin{array}{r}\text { Beavis et al. }(2015) \text { 'Computer games } \\
\text { can get your brain working': } \\
\text { student experience and } \\
\text { perceptions of digital games } \\
\text { in the classroom }\end{array}$ & - & Artigo & The University of Queensland \\
\hline $\begin{array}{l}\text { Uusi-Mäkelä (2015) Learning English in } \\
\text { Minecraft: a case study on language } \\
\text { competences and classroom practices }\end{array}$ & Vygotstky & Dissertação & University of Tampere \\
\hline $\begin{array}{r}\text { Yoon e Kim (2015) Challenges and } \\
\text { opportunities in game artificial } \\
\text { intelligence education using Angry Birds }\end{array}$ & - & Artigo & Sejong University \\
\hline $\begin{array}{r}\text { Sun et al. (2015) Effects of commercial } \\
\text { video games on cognitive elaboration } \\
\text { of physical concepts }\end{array}$ & Bousquet & Artigo & National Chiao Tung University \\
\hline $\begin{array}{r}\text { Stokrocki (2013) Youth-created avatars, } \\
\text { sites, and role-playing in the virtual } \\
\text { game The Sims } 2\end{array}$ & Mandinach & Artigo & University of Tampere \\
\hline $\begin{array}{r}\text { Checa-Romero (2015) Developing Skills } \\
\text { in Digital Contexts Video games and } \\
\text { Films as Learning Tools at } \\
\text { Primary School }\end{array}$ & Piaget & Artigo & University of Alcala, Spain \\
\hline $\begin{array}{r}\text { Pereira et al. (2016b) Jogos Digitais } \\
\text { no desenvolvimento de conceitos } \\
\text { matemáticos sob perspectiva BYOD } \\
\text { e abordagem m-Learning na } \\
\text { escola pública }\end{array}$ & Feuerstein & Artigo & USP \\
\hline $\begin{array}{r}\text { Pereira et al. (2016a) Mathematics } \\
\text { experiences: Pedagogical implications } \\
\text { with the use of digital games, } \\
\text { m-learning and social networks }\end{array}$ & Feuerstein & Artigo & USP \\
\hline
\end{tabular}


ajudar os professores no ensino para a criação e o desenvolvimento de narrativas e da escrita em inglês. Aponta também que o uso de games enriquece a experiência e a retenção do aprendizado.

O artigo de Söbke et al. (2013) propõe a discussão sobre uma abordagem sistemática para facilitar jogos digitais comerciais na sala de aula como uma atividade auxiliar, opcional e diferenciada do uso individual de jogos educacionais.

Avraamidou et al. (2015b) investigou conteúdos de matemática em três jogos populares (Angry Birds, Plants vs. Zombies e The Sims). Os três jogos são diferentes, mas cada um foi observado para garantir oportunidades para a atividade matemática na jogabilidade. Depois de descrever cada jogo, e a Matemática que pode surgir na jogabilidade, o capítulo explora duas perguntas: Que tipo de Matemática é oferecida nestes jogos? Estes jogos podem ser usados em/para a Matemática da escola? Pontos considerados no âmbito da primeira questão incluem: a natureza da Matemática e da dificuldade de isolar a Matemática na jogabilidade não-escolar; a natureza dos jogadores e das ações estratégicas como ações matemáticas; e "verdade" e seus mandados em mundos de diferentes matemáticas. Outros aspectos, considerados no âmbito da segunda questão, incluem: tensões entre as expectativas curriculares e as matemáticas que surgem no jogo e possíveis mudanças na jogabilidade quando um jogo é movido de um espaço de lazer para um ambiente educacional.

O trabalho de Beavis (2015) incide essencialmente sobre as dimensões textuais de jogos e jogabilidade, dentro do contexto da New Media Age. Focaliza questões relacionadas às multialfabetizações e alfabetização construída como design. Identifica também as maneiras com que a capacidade de ler e agir sobre letramentos multimodais permite raciocínio, análise e o progresso bem sucedido do jogo. Leva o exemplo do Statecraft X, um jogo educativo móvel, com foco em cidadania, para explorar e ilustrar assuntos como esses. Ele aborda e enfatiza algumas das formas multimodais de leitura, instrução e interações necessárias para conferir sentido ao jogo; identifica como ativar as formas com as quais os alunos podem chegar a novos conhecimentos e entendimentos sobre gerenciamento e cidadania, e mostra os tipos de investimento e de raciocínio, além dos pressupostos necessários para fazê-los.

No artigo de Beavis et al. (2015) foram apresentados os resultados de um levantamento de 270 alunos do ensino primário e secundário em relação aos anos do quarto ao nono (idade entre nove e quatorze anos) em seis escolas de Queensland, no início de um projeto da Australian Research Council que passou três anos pesquisando o uso de jogos digitais na escola para promover a alfabetização e a aprendizagem.

O trabalho de Uusi-Mäkelä (2015) descreve os estudos de caso realizados em um curso voluntário de formação em Inglês, com o objetivo de utilizar métodos de observação e pesquisa para descobrir quais são os problemas associados com a exploração dos jogos e quais aspectos e competências linguísticas dos alunos são desenvolvidas durante o ato de jogar. O jogo utilizado foi o Minecraft versão educacional, MinecraftEdu. No curso, os alunos jogaram cooperativamente e competitivamente. O estudo envolveu um total de 29 alunos em idade de ensino médio e constatou que os principais desafios são fornecer um ambiente de comunicação língua-alvo autêntica, bem como um equilíbrio entre jogar de forma guiada ou livremente, sem objetivos definidos. A competência existencial, a capacidade de aprender e a competência pragmática dos alunos destacaram-se claramente nas respostas. O estudo levanta uma série de questões para futuras pesquisas. Por exemplo, uma distribuição diferente de competências em matéria de formação a longo prazo requer uma pesquisa mais ampla e de longo prazo. O estudo mostrou que os alunos sentiram que o uso do jogo 
envolvia habilidades que normalmente não são utilizadas no âmbito da educação formal.

Yoon e Kim (2015) realizou competições, entre alunos de graduação do curso de Ciências da Computação, de tal forma que os participantes desenvolveram as suas próprias aplicações de Inteligência Artificial (IA) para controlar jogos digitais. Em tal trabalho, foram apresentadas suas experiências usando a competição de IA no jogo digital Angry Birds. Os alunos participaram ativamente do projeto e o resultado final foi comparável com o de entradas bem sucedidas no 2013 International Angry Birds AI Competition.

O trabalho de Sun et al. (2015) usou conceitos de Física para investigar a elaboração cognitiva utilizando um método de revisão de jogo digital versus um método tradicional de leitura. Os experimentos envolveram dois jogos digitais: Cut the Rope (conceito pêndulo) e Angry Birds Space (movimento circular), com o conceito de mapas e testes de múltipla escolha utilizados como instrumentos de avaliação. O objetivo de tal trabalho foi analisar o conceito de reforço e reorganização através de jogos digitais para um grupo de estudantes da escola secundária. Um total de 83 alunos (de 15 a 16 anos) foi aleatoriamente designado para um grupo experimental (revisão usando jogos casuais comerciais) ou um grupo controle (revisão baseada em conferência). Os resultados sugerem que os jogos apoiam o potencial de elaboração de conceitos de Física, pois os alunos aprenderam como medir por mapas conceituais, e os mapas conceituais são mais adequados do que os testes de escolha múltipla para estimar os efeitos de jogos comerciais na elaboração cognitiva. Essa produção discutiu três características principais do projeto de jogos comerciais que podem apoiar a elaboração cognitiva de conceitos físicos.

O estudo de Stokrocki (2013) examinou como cinco adolescentes aprenderam e jogaram um jogo digital, o The Sims 2. Através da observação, foram examinadas as preferências estéticas dos participantes, as práticas espaciais, as estratégias de aprendizagem e a narrativa de histórias dentro do jogo. O contexto deste estudo foi a 10-week summer day camp, realizada em uma comunidade no Arizona. Foram encontradas, no descrever dos avatares e na construção das casas dos participantes, estratégias para a tomada de decisões espaciais rápidas e para a escolha de ferramentas usada nessas construções. Situado no interior de um quadro arte-educação, cultura visual e material, e com a atenção para a necessidade dos professores se envolverem em mídias de alfabetização, o estudo contribuiu para as pesquisas anteriores sobre lugares de jogos digitais, realidade virtual e educação midiática.

Checa-Romero (2015) realizou um estudo etnográfico em uma escola primária espanhola. Tal trabalho apresenta uma análise das habilidades que podem ser desenvolvidas através do uso do jogo digital e do filme Harry Potter e o Cálice de Fogo e como profissionais da educação podem usá-los na escola, a fim de mudar a forma como os alunos aprendem. Os resultados mostraram como os alunos podem desenvolver sua capacidade crítica, comparando esses dois meios de comunicação e o que isso lhes permite desenvolver nos processos orientados para o letramento digital, da mesma forma com que ajuda a se tornarem produtores de conteúdo, através da criação e publicação de blogs.

Pereira et al. (2016a,b) apresentou possibilidades de uso de jogos digitais para a aprendizagem de conceitos matemáticos. Utilizou uma composição de dispositivo móvel sob a perspectiva Bring Your Own Device (BYOD) e o apoio de redes sociais, em escola estadual de ensino fundamental II. Foram evidenciados desafios, tais como: a ausência de formação de professores sobre o tema; problemas com infraestrutura tecnológica incompatível com as atividades pedagógicas adequadas; e 
a necessidade da criação de uma metodologia sobre o uso de jogos digitais como apoio na construção de conceitos matemáticos.

Em suma, a nossa sociedade tem convivido com jogos desde muito tempo. Os jogos fazem parte essencial da cultura humana, entretanto os avanços das tecnologias digitais e principalmente dos dispositivos móveis requerem mais estudos a fim de provar que eles têm sido vistos, cada vez mais, positivamente, devido ao fato de suas próprias características. A revisão dos estudos comprova que, embora os autores que pesquisaram sobre jogos digitais afirmem seus resultados positivos, são restritas as produções que relacionam as competências e habilidades educativas como resultados esperados de aprendizagem pelos sistemas de ensino. Não importa o tipo ou a modalidade de jogo, uns dos seus princípios são o divertimento, o prazer, a concentração e a motivação, mas se os considerarmos na área da educação, pode-se observar que eles possuem elementos que podem ajudar estudantes em novas maneiras de interagir com a vida real, ou até se sentir mais interessados por resolver seus problemas. 


\section{Capítulo 4}

\section{Horizonte Teórico Interpretativo}

O presente capítulo identifica as categorias teóricas e seus respectivos autores abordados na análise da pesquisa-ação, para a compreensão da realidade investigada.

Um dos autores escolhidos como horizonte teórico interpretativo dos dados coletados na realidade investigada é Reuven Feuerstein. Este nasceu em Botosan (Romênia) em 1921 e faleceu em 2014, aos 92 anos. Em 1944 ensinava em Bucareste, numa escola para filhos de deportados. Nesse mesmo período, foi mandado para um campo de concentração quando a Romênia foi ocupada. Conseguiu escapar e imigrou para Israel, onde se dedicou à educação dos adolescentes sobreviventes ao Holocausto e das crianças sobreviventes que foram para outros países como refugiados. Seus alunos não correspondiam aos educadores e às atividades comuns, não participavam, iam mal nas avaliações e assim por diante. Apresentavam carências cognitivas muito semelhantes aos indivíduos com deficiência mental. Feuerstein detectou o que foi chamado inicialmente de privação cultural. Tais alunos sofriam, entre outras coisas provenientes das mazelas do holocausto, com problemas de diversidade cultural e problemas de comunicação, por falarem línguas diferentes ou mesmo por não serem familiarizados com os símbolos da cultura que os acolhera. Dessa forma, foi desvelado que os alunos não eram deficientes, ou intelectualmente incapazes, e sim que haviam diversos problemas que impediam seu desenvolvimento cognitivo, ou seja, em situações psicológicas, sociais e culturais desfavoráveis, as crianças não podem apropriar-se do saber e isso não quer dizer incapacidade (Feuerstein, 1970).

Foi a partir dos estudos com esses adolescentes que Feuerstein e seus colaboradores desenvolveram um sistema de avaliação do potencial de aprendizagem (LPAD) e um programa de intervenção cognitiva (PEI), que se tornou conhecido como método Feuerstein (Da Ros, 2002).

No período de 1940 a 1944, frequentou o Teachers College e o Onesco College, em Bucareste. De 1944 a 1945 estudou no Teacher Training Seminary, em Jerusalém. Em 1949 foi para a Suíça, onde frequentou palestras e seminários de Carl Jaspers, Carl Jung e L. Szondy. Entre 1950 e 1955 estudou na Universidade de Genebra, sob a orientação de Andrey Rey e Jean Piaget, onde se formou em Psicologia Geral e Clínica, em 1952. Obteve sua licença em Psicologia no ano de 1954. Em 1970 Feuerstein defendeu seu doutorado em Psicologia do Desenvolvimento na Sorbonne.

Embora Feuerstein tenha estudado com Piaget, e elaborasse algumas considerações evidentemente conectadas a premissas piagetianas, a ênfase sociocultural de Feuerstein encontra paralelo na abordagem teórica de Vygotsky, a respeito das interações socioculturais da criança. Feuerstein, assim como Vygotsky, salienta a dinâmica dos processos interativos como fonte propulsora de desenvolvimento. Desse pressuposto, infere-se o conceito de mediação. Feuerstein aproxima-se da abordagem 
vygotskyana de mediação por meio do conceito da Experiência de Aprendizagem Mediada (EAM). Para ele, existem duas modalidades através das quais é possível ocorrer o desenvolvimento cognitivo do sujeito: a interação direta entre sujeito e objeto e a EAM.

"Os postulados de Vygotsky e Feuerstein apontam para a necessidade de criação de uma nova ordem escolar bastante diferente da realidade que vivenciamos em nossas escolas. Ou seja, uma escola em que os sujeitos da educação possam dialogar, duvidar, questionar e compartilhar saberes. Uma escola em que haja espaço para o erro, para as contradições e as diferenças, para a cooperação e a criatividade, onde alunos e professores não sejam meros 'repetidores' do saber acumulado pela humanidade, mas sim, autores do próprio pensar, isto é, uma escola em que o conhecimento sistematizado não seja tratado de forma dogmática sem significado." (Salami e Sarmento, 2011, p., 8).

\subsection{Modificabilidade Cognitiva Estrutural (MCE)}

O termo "modificabilidade cognitiva" é utilizado por expressar a ideia de um processo voltado à autonomia do sujeito. Essa modificabilidade é focada em um ambiente, circunstâncias e situações de constante modificações.

Modificabilidade também associa-se à palavra "estrutural", que se volta inteiramente para determinantes interacionais como aspectos centrais no desenvolvimento. O termo "estrutural" propõe que há uma relação dinâmica constante do sujeito com o ambiente, estando sempre em movimento, integrado com a realidade sociocultural. Isso, no entanto, não quer dizer, em momento algum, que aqui se defendam as concepções que afirmam as aprendizagens como resultado direto da ação condicionadora dos estímulos ambientais.

A modificabilidade cognitiva estrutural está fortemente relacionada com o contexto sociocultural do aluno e o tempo histórico, não estando nem no ambiente nem no sujeito isolado. É preciso prestar atenção nas interações, pois a capacidade de se modificar é virtual, de modo que é relativa a certas condições do ambiente cultural, criadas pelas experiências de aprendizagem mediada. A MCE resulta, em parte, do estabelecimento de relações com o mundo e da maneira de viver suas experiências de aprendizagem.

Modificabilidade é a condição fundamental à adaptação, sendo esta última entendida como a possibilidade de respostas que não constituam simples reação à ação de um estímulo do meio, mas a elaboração mental permeada por determinadas significações. Inteligência é a possibilidade de adaptação de algo construído. Entretanto, nessa construção, não existe nada pré-configurado como previsão de desenvolvimento. Como as demandas de adaptação são engendradas culturalmente sendo expressão e fundamento das relações entre os homens, e não algo específico do organismo biológico em si -, a inteligência é definida como construção mediada (Da Ros, 2002).

Esta pesquisa apresenta os resultados obtidos de dados coletados fundamentados teoricamente pela teoria da MCE, que reconhece o organismo humano como aberto, adaptável e passível de mudança. Diferentes mudanças se dão na estrutura do pensamento de um indivíduo, criando condições para que se possa adquirir novas palavras para criar o processo de pensar em novas coisas que previamente não faziam sentido em sua mente. Assume-se que a pessoa é capaz de adquirir, de maneira autônoma, não apenas diferentes conhecimentos ou habilidades, mas também novas estruturas cognitivas, pelas quais são abertas novas áreas previamente não inclusas em seu conjunto de 
conhecimentos e habilidades prévias (Feuerstein et al., 2014).

O conceito de MCE refere-se, especificamente, à possibilidade de o sujeito corresponder às exigências intelectuais que, em outra situação, não conseguiria. Sugere também que o indivíduo é capaz de se modificar, de quebrar as "amarras" cognitivas que o fixam, por exemplo, a um diagnóstico de deficiência mental. Feuerstein pretende conferir à modificabilidade uma conotação ampla, que transcende o limite do indivíduo em si para chegar ao sujeito cultural. Essa mediação coloca à disposição da pessoa novos significados e sentidos culturais. A MCE é incluída por Feuerstein no plano da ação educativa, então utiliza de modo deliberado certos instrumentos mediadores que dão novo rumo à relação do aprendiz com o meio e consigo mesmo (Da Ros, 2002).

\subsection{Experiência de Aprendizagem Mediada (EAM)}

A análise dos dados coletados nesta tese centrou-se na percepção quanto à modificação do indivíduo, enfatizando as mudanças na autonomia e na autorregulação. Essas mudanças são facilitadas através de Experiências de Aprendizado Mediado (EAM). As EAM não tratam apenas de exposições de estímulos. As presenças de um mediador de estímulos ao aprendiz provocam interconexões internas e socioculturais, como explicitam os estudos desenvolvidos por Vygotsky e seus parceiros.

Os principais fatores da EAM são tanto o aprendiz quanto seus colegas e professores, portadores de diferentes experiências que têm o papel de exercer influência crucial no desenvolvimento do ser humano. Os mediadores humanos e/ou culturais são responsáveis pelo compartilhamento dos elementos culturais mais amplos e significativos dos objetos e eventos da experiência direta ou vivenciada pelos aprendizes (Da Ros, 2002; Feuerstein et al., 2014).

A abordagem comportamental utiliza exposição direta ao estímulo (S), na tentativa de causar uma mudança de comportamento por induzir uma resposta (R), modelo estímulo resposta (S-R). Piaget adicionou o organismo $(\mathrm{O})$ à equação (S-O-R), de forma a considerar fatores socioculturais do indivíduo como idade e estágios de desenvolvimento, como função dos processos de maturação, para poder explicar não somente as formas de resposta do organismo, mas também quais têm significância ou não para si.

Nessas duas abordagens não existe referência à função do fator humano, portador da cultura e conhecimento acumulado de experiências de vida além do conhecimento acadêmico, no processo do desenvolvimento cognitivo. Aquele que inicia a mudança, o mediador humano, não é levado em consideração.

A criança aprende com um objeto novo encontrado, seja uma árvore, ave ou brinquedo, porém com a presença de um mediador humano existe a possibilidade de mediar, com propósito e intenção, os objetos e a natureza em conformidade com símbolos pertencentes à cultura dos envolvidos no processo. O mediador humano é responsável por transmitir elementos culturais mais amplos e significativos dos objetos e eventos de uma exposição direta.

Seguindo essa perspectiva, Feuerstein utiliza uma abordagem que pode ser ilustrada no diagrama do funcionamento da EAM, descrita na Figura 4.1. O elemento humano "H" é responsável pela mediação (Figura 4.1), criando, dessa forma, experiências controladas com estímulos e intenções pedagógicas previamente definidas. O estudante e a construção de conhecimento dele é o foco central da abordagem.

Tais experiências permitem que os estudantes, e seus conhecimentos prévios para executar ações, 


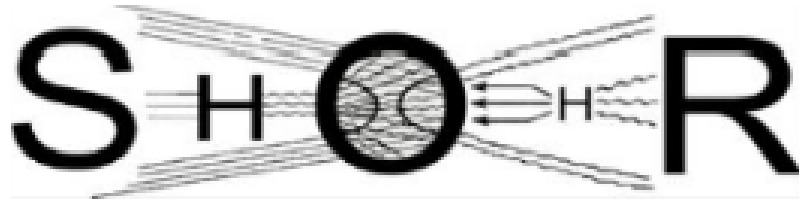

Figura 4.1: Modelo EAM retirado de (Feuerstein et al., 2014, p. 65)

sejam considerados e valorizados pelos professores para repetir ações bem sucedidas e evitar os erros. Segundo Feuerstein et al. (2014), em conformidade com Fonseca (2014), Klein et al. (2000), Gomes (2001) e Campos e Macedo (2011), a EAM trabalha com as seguintes competências cognitivas: autorregulação e controle de comportamento; intencionalidade e reciprocidade; construção de significado; transcendência; sentimento de competência; compartilhamento de comportamentos; busca por objetivos e metas; planejamento para o alcance dos objetivos; busca pela novidade e complexidade; sentimento de pertencer; automodificação; e individuação e diferenciação psicológica.

Feuerstein corrobora Vigotsky (1989) e coloca que, para compreender integralmente a natureza do desenvolvimento humano, é preciso entender as interações entre o ser humano, o ambiente e as experiências socioculturais, pondo a pessoa em interações diretas e mediadas por outro humano (Reuven, 1980).

Uma das contribuições mais importantes de Vygotsky é o conceito de Zona de Desenvolvimento Proximal (ZDP). Trata-se do potencial de aprendizagem de um indivíduo quando existem outras pessoas com conhecimento superior para ampliar suas compreensões na construção dos conhecimentos.

A imaginação trabalhada nas atividades que envolvem jogos permite que a criança, ou aluno, relacione seus interesses e necessidades com as atividades e intenções do mediador. Vygotsky (1967) afirma que a influência do brinquedo é muito importante para o desenvolvimento cognitivo das crianças.

A ação dentro de uma situação lúdica ensina o estudante a orientar seu comportamento pela percepção imediata dos objetos envolvidos em um jogo, pela situação que a afeta de imediato e pelo significado dessa situação.

Vygotsky identificou em suas pesquisas que o brinquedo ou os jogos ajudam a desenvolver uma diferenciação entre a ação e o significado. Permitem estabelecer relação entre jogar e a ideia que se tem dele; o jogo relaciona-se com a aprendizagem onde jogar é aprender e o lúdico torna-se uma proposta educacional para o enfrentamento de novas dificuldades no processo de ensino/aprendizagem. Jogar ensina a lidar com sentimentos de alegria e sucesso bem como sentimento de frustração e de erro. Dessa forma o jogo prepara para futuras atividades do trabalho: estimula a concentração, estimula a autonomia para fazer escolhas incentiva a autoestima e ajuda a desenvolver relações de confiança consigo e com os outros. Portanto jogar é uma aprendizagem que ativa a criatividade, contribui diretamente para a construção de conhecimento e auxilia o professor a compreender as necessidades de aprendizagem de cada aluno.

Segundo Vygotsky o aprendizado é um aspecto necessário para o desenvolvimento das funções psicológicas, as quais são organizadas pela cultura $\mathrm{O}$ desenvolvimento da pessoa está extremamente ligado a sua relação com o ambiente sociocultural e dessa forma o desenvolvimento pode ficar impedido de ocorrer na falta de situações propícias e motivadoras ao aprendizado.

A mediação e o mediador possuem uma ZDP, que promove a interação entre colegas em busca 
de um conhecimento. De acordo com essas ideias, o jogo digital revela-se como um instrumento de extrema relevância pelo envolvimento que proporciona.

Numa situação de ensino/aprendizagem vivenciada no trabalho escolar a presença dos jogos digitais situa-se na intersecção das ZDP dos alunos, professores e conteúdos, conforme a Figura 4.2.

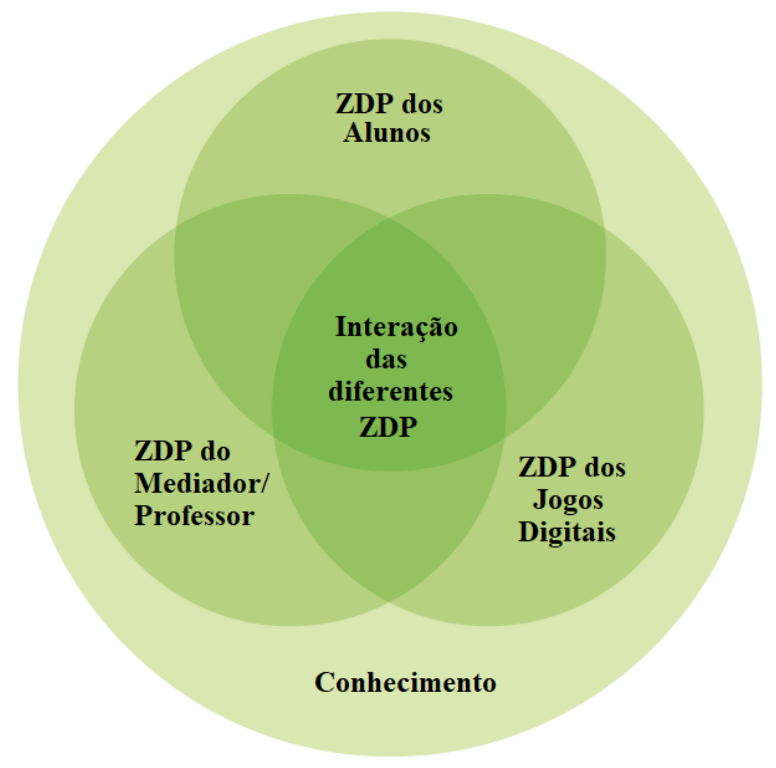

Figura 4.2: Interação das ZDP

\subsection{Competências da EAM}

Para Feuerstein et al. (2014), a interação mediada necessita de dois grupos de parâmetros ou, como é chamado atualmente, características de mediação, que são competências necessárias para que aconteça a modificação do indivíduo no sentido de gerar o aprendizado diferenciado de uma interação qualquer para uma EAM.

O primeiro grupo contém competências que são responsáveis pelo caráter universal da modificabilidade humana e pela flexibilidade e plasticidade que caracteriza o ser humano. Sem estas, a interação não seria de mediação. São elas:

1. Intencionalidade e reciprocidade: Na interação mediada o conteúdo específico da interação, por mais importante que seja, é moldado pela intencionalidade da mediação. O mediado precisa reconhecer um foco a um objeto em particular, um local e um momento específico e particular da EAM. A intencionalidade molda os estímulos para que sejam mais significantes, poderosos, importantes, imponham-se mais para o mediado. O ajuste de fluxo e intensidade do mediado deve ser efetuado de modo que o aluno não fique entediado, sonolento, disperso e assim por diante. Porém a intencionalidade em si não é suficiente. É possível encontrar intencionalidade além da cultura, por exemplo, nos animais, assumindo que um gato leva seus filhos para o jardim ensinando como esconder seus dejetos de modo a encobrir rastros, para que não sejam rastreados por predadores. Com os humanos, a mediação tem a intenção de ir além da situação na qual ela é realizada, isso nos leva à segunda competência da EAM.

2. Transcendência: Esta competência se relaciona com a capacidade do mediado de conse- 
guir estender a experiência imediata, transpondo as competências obtidas ao longo da vida e da experiência em questão para realizar objetivos desafiadores e diferentes dos que já tenha passado e, dessa forma, ter competência de agir em meio a coisas novas e à incerteza. Na transcendência se trabalha a distância temporal em relação a um objetivo, onde o mediado, auxiliado por um mediador, executa atividades que darão resultados a longo prazo. Nisso reside também a capacidade de abstração, de conceitos e atividades, dessa forma sendo capaz de antecipar acontecimentos futuros que são direcionados por ações e decisões tomadas previamente: "o que aconteceria se agisse de forma diferente, além das nossas necessidades imediatas?". Dessa forma, espera-se com a transcendência que o mediado seja capaz de transferir o que foi aprendido para todas as áreas da vida.

3. Significado: Esta é a terceira competência essencial para a execução de interações com valor de mediação. A transmissão direta de conteúdo não é suficiente para assegurar o desenvolvimento cognitivo, é necessário que o mediador seja responsivo a perguntas como: "Por que este conteúdo é importante?" "Por que precisa ser aprendido?" Com isso, cria-se uma capacidade energética, que constitui um motivo para aceitar e absorver a mediação. A mediação do significado cria motivação para a mediação, impulsionando as atividades para que haja o aprendizado significativo. A construção do significado faz com que o sujeito entenda a mensagem do mediador e racionalize sobre ela, estenda-a e aplique-a em situações além da imediata e, dessa forma, possa levar a mediação para significados mais profundos e pessoais para si mesmo. Outra contribuição para a construção do significado é que o mediador deve criar no mediado a capacidade de construir por si próprio o significado em relação aos acontecimentos de sua vida e cultura, ter, dessa forma, opinião própria, pois ao longo da vida significados podem mudar e o mediado tem que ter a capacidade de se adaptar às mudanças imprevisíveis.

O segundo grupo de competências inclui as que direcionam a modificabilidade de diferentes formas, dependendo da cultura e da diferença interpessoal, responsáveis pela diferenciação da interação de mediação. São reflexos da ecologia, da cultura e das características únicas de cada ser humano, que são responsáveis pelas vastas diferenças na qualidade das interações pessoais. Também tem relação com as necessidades particulares de nossa era, que demanda constante adaptação às mudanças tecnológicas e culturais. São elas:

4. Sentimento de competência: Necessária para humanos agirem com competência. Para cumprirem desafios e lidarem com situações novas, devem sentir que são competentes para controlar estas situações, para vencerem dificuldades, para se familiarizarem com o novo e o desconhecido e para abordarem desafios com expectativas que estes sejam vencidos. Deve-se ater ao sentimento de competência da competência em si, pois o mediado pode ser capaz mas não acreditar que é. O sentimento de competência não existe no ser humano de forma inata, o desenvolvimento deste sentimento requer feedback. O mediador deve propor desafios com níveis de dificuldade ajustados a uma certa distância do mediado, dando a ele ferramentas para lidar com novas tarefas, explicando seu funcionamento bem sucedido. Durante e após as experiências mediadas, é necessário oferecer ao mediado interpretações de experiências de sucesso que viveu para que tome conhecimento do significado de seu sucesso e a ligação da prova de sua competência em uma tarefa a futuros sucessos em outras tarefas que possam vir. 
5. Autorregulação e controle do comportamento: A autorregulação tem duas faces, uma delas diz respeito ao controle pessoal, no sentido de se restringir respostas, onde o sujeito ao se deparar com um estímulo não responde de imediato, restringe-se em um tempo para pensar, racionalizar e/ou analisar os dados e se tem os dados necessários a serem processados antes de agir. A regulação do comportamento é um ato voluntário resultante de uma decisão de suspender a resposta até que seja verificada a situação exposta. A outra face é quando uma situação de urgência, ou emergência, exige uma resposta imediata. Autorregulação é, portanto, a capacidade que um indivíduo tem de examinar a si mesmo e avaliar uma dada situação, e, então, decidir como e quando reagir.

6. Comportamento de compartilhar: Esta competência em nosso mundo atual é demandada pois a habilidade de compartilhar experiências com outros seres humanos e participar de suas experiências é necessária, desejável e faz parte do cotidiano das pessoas, sendo uma necessidade da cultura contemporânea. Essa demanda aumenta ainda mais com a grande participação das tecnologias da informação, mais especificamente das redes sociais. Diz respeito à habilidade de fazer contato com outros seres humanos, ficar próximo dos outros e criar harmonia entre experiências compartilhadas. Essa competência é necessária para a adaptação do indivíduo. Não se limita ao aspecto emocional, existe nela o potencial de enriquecer o desenvolvimento cognitivo. Também tem duas faces, o receptor do que é transmitido participa no que é significativo para o transmissor, confirmando sua experiência, e quem transmite reforça a experiência vivida para outros, também reforçando o significado e a integridade de sua experiência.

7. Individualização e diferenciação psicológica: Em paralelo, e talvez em contraste, com a competência anterior, essa competência se faz importante para que o indivíduo construa sua individualidade, o sentimento de ser uma entidade humana separada, com direitos de se expressar e pensar de forma especial que o distingue dos outros. Pode parecer paradoxal com a competência anterior, mas não é contraditória. É complementar no ser humano, que pertence a grupos sociais, cultura, família e assim por diante, porém é ao mesmo tempo um ser individual e separado, com necessidades, anseios e vontades distintas. Essa competência é necessária para que o indivíduo possa expressar opiniões próprias e impor-se a um ou outro aspecto de suas experiências. A consciência do mediado quanto à legitimidade das diferenças de opiniões, tendências, desejos e estilos, sem necessariamente aceitar isto, representa uma condição importante para um processo adequado de individualização. A valorização das diferenças entre os indivíduos e seus comportamentos únicos leva à formação de autopercepção distinta e aceitável com relação a outros. Por outro lado, se não for orientada corretamente, pode levar ao desenvolvimento de uma personalidade egoísta, arrogante e egocêntrica, que não identifica seus limites, portanto, não se percebe como entidade distinta e independente.

8. Planejamento para alcance de objetivos: Esta capacidade está relacionada ao poder de abstração gerado em um indivíduo com um objetivo em foco no seu repertório mental. Cabe ao mediador apresentar um repertório de objetivos em potencial. Estes podem aumentar a esfera de consciência do mediado com relação ao que é possível, desejável e alcançável. Esta competência está relacionada também com o pensamento crítico, onde o mediado, para alcançar seus objetivos, apresenta uma perspectiva do futuro muitas vezes distante, demandando 
rejeição de gratificações imediatas, e cria uma tensão entre a vontade, a necessidade e o suprimento dela. A possibilidade de viver e experimentar no pensamento abstrato o que ainda não foi vivido, mas que é desejável, colocando objetivos a serem realizados no futuro, faz com que o ser humano use formas abstratas do pensamento, a imaginação na representação do que ainda não existe. Este processo tem função extremamente importante na estruturação de operações mentais mais elevadas, que caracterizam a inteligência humana. A colocação de objetivos distantes demanda planejamento e ações para alcançá-los, tal fato cria valor transcendental, ampliação do campo mental e espaço expandido.

9. Busca por desafio, novidade e complexidade: A busca por desafios e complexidade é motivadora e se dá quando o indivíduo está pronto e é embutido do sentimento de ser capaz de alcançar objetivos em atividades novas, as quais o mediado não está familiarizado. Esta competência está relacionada à adaptabilidade do indivíduo em mudanças e às complexidades desafiadoras presentes no seu entorno. A prontidão para aprender e se mover de situações conhecidas para situações desconhecidas, confrontando novidades desafiadoras, é essencial para a adaptação do indivíduo.

10. Automodificação: Esta competência, além das mudanças biológicas, está relacionada à percepção que um indivíduo tem de si e de como é percebido por outros e à capacidade que um indivíduo tem de se modificar, possuidor de uma identidade contínua. Tem relação com a consciência da possibilidade e da necessidade de fazer um esforço de alcançar objetivos de desenvolvimento e melhoria. A capacidade de perceber modificações que estão ocorrendo, ou perceber quais comportamentos e atitudes deve modificar para se adaptar às necessidades.

11. Alternativa otimista: Quando um indivíduo escolhe uma alternativa pessimista, preocupandose com o pior caso, tende a permanecer inerte, na sua zona de conforto, com uma postura passiva. A competência de escolher uma alternativa otimista cria no indivíduo força, motivação e interesse em sair de sua zona de conforto em busca de realizar seus objetivos. Também impõe a responsabilidade de executar ações para materializar o que é visto como possível. Quando o mediado consegue perceber que existe uma diversão em uma determinada atividade, fica inclinado a buscar uma alternativa otimista. Tal expectativa gerada leva o mediado a aceitar mudanças e desafios e aumenta sua prontidão para atacar fatores ambientais que ameaçam seu equilíbrio físico e mental. Desta forma, o mediado se permite desenvolver estratégias, em operações mentais, de situações encontradas, que transcendem para futuras soluções que serão vividas.

12. Sentimento de pertencer: Esta competência pode variar de uma cultura para outra. $O$ sentimento de pertencer implica a ideia da inclusão, seja no elo familiar, na cultura ou em um grupo de amigos. O ser humano é um ser social e necessita estar em um grupo, seja ele formal ou informal. Essa competência estimula o sentimento de acolhimento entre o indivíduo e um determinado grupo social, sem este sentimento as relações não se estabelecem. 


\section{Capítulo 5}

\section{Contribuições dos Jogos Digitais e Competências Curriculares da Matemática}

Este capítulo analisa os dados da realidade investigada, cujas observações e acompanhamentos do projeto Games e o Ensino da Matemática foram realizados no espaço curricular obrigatório conhecido como Oficinas de Experiências Matemáticas. Apresenta as análises, a interpretação e o entendimento triangulados dos dados coletados como as entrevistas, os grupos focais, as sessões de atividades com os jogos digitais, os registros do diário de campo, os diálogos com os professores e a direção da escola, os diálogos entre os pesquisadores do Grupo Alpha, os registros obtidos através das redes sociais utilizadas, entre outros procedimentos. Articula no contexto escolar as ações dos jogos vinculados ao currículo de Matemática dos $7^{\circ}, 8^{\circ}$ e $9^{\circ}$ anos, implícitos e explícitos.

Os dados foram analisados conforme roteiro mapeado anteriormente e apresentado na Figura 5.1.

A modificabilidade cognitiva promovida pela EAM, abordada na teoria de Feuerstein et al. (2014), foi confirmada na Escola Estadual Fernando Nobre, apesar dos reduzidos índices de aproveitamento na disciplina Matemática. Fundamenta as análises com a teoria de Feuerstein, levando em consideração o conjunto de resultados encontrados durante as mediações efetivadas, conforme apresentado no Quadro 5.1.

Não se pode compreender o desenvolvimento de competências cognitivas, docentes e discentes, isoladas em seus pensamentos, reflexões e sentimentos. Existe uma produção de conhecimentos decorrente do espaço e das estratégias pedagógicas que necessitam de diálogo coletivo e interativo. Cabe ao docente planejar, orientar, acompanhar e avaliar o processo de apropriação, dando acesso aos alunos a recursos necessários para o desenvolvimento interpessoal e intrapessoal, como descreveu Vygotsky (1967). É nesse espaço que o professor assume a função de mediador, aquele que vai criar oportunidades de ação para que ocorra a produção de novos conhecimentos.

Uma das tecnologias viáveis encontrada na escola foi a presença dos smartphones em quase 100\% dos estudantes pesquisados (Apêndice E). A presença de apenas 15 computadores na sala de Informática inviabiliza qualquer projeto escolar dada a sua precariedade de infraestrutura e manutenção. Os professores declararam que possuíam computadores também, mas especificamente para uso pessoal (Apêndice F). Dessa forma, para esta pesquisa, foram utilizadas as perspectivas 


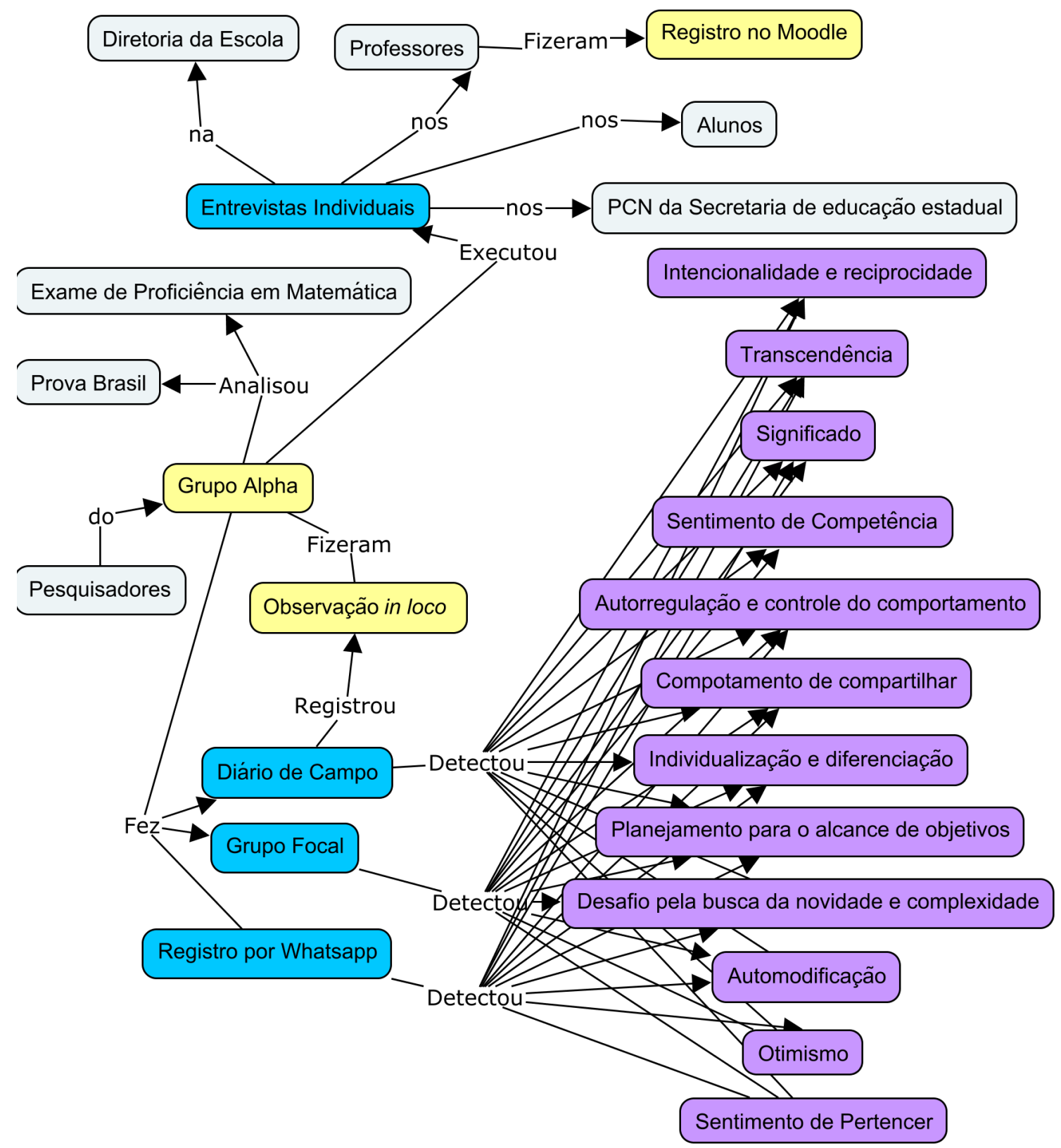

Figura 5.1: Mapa conceitual da triangulação de dados

do BYOD, m-learning, Flipped Classroom, blended learning e uso dos celulares no contraturno das aulas regulares, ou seja, nas oficinas culturais inseridas no Plano Global da Escola. Isso atendeu os objetivos do que se conhece como Flipped Classroom, ou seja, estratégia instrucional que inverte a organização tradicional de como o aluno acessa os conteúdos que serão aprendidos na sala de aula.

As primeiras sondagens diagnósticas realizadas com os alunos apontaram o grande interesse por jogos digitais e pelo uso do smartphone em sala de aula, principalmente como suporte das aulas comuns desenvolvidas pela manhã nas salas de aula tradicionais (Apêndice E). Com posse desse conhecimento, buscou-se dentre os jogos citados pelos alunos alguns que fossem compatíveis tanto com seus interesses quanto com os conteúdos curriculares de Matemática: SimCity BuildIt, Clash of Clans e The Sims Freeplay. A escolha destes jogos atendeu às indicações dos alunos e levou em consideração elementos e características de game design articuladas às percepções dos professores quanto às dificuldades mais críticas enfrentadas pelos alunos em questão (Quadros 2.4 e 2.5). 
Quadro 5.1: Unidades de Análise fundamentadas por Feuerstein

\begin{tabular}{l|l}
\hline \multicolumn{1}{c}{ Unidades de Análise } & \multicolumn{1}{c}{ Registros da triangulação dos dados } \\
\hline Intencionalidade e Reciprocidade; Interação Mediada & $\begin{array}{l}\text { Jogos Digitais, } \\
\text { pesquisador - contexto escolar }\end{array}$ \\
\hline $\begin{array}{l}\text { Transcendêndia; Transposição da experiência vivida } \\
\text { para outras áreas de conhecimento }\end{array}$ & $\begin{array}{l}\text { Interdisciplinaridade com outras } \\
\text { areas de conhecimento Saúde, } \\
\text { Ciências, Política, Cidadania, Saneamento }\end{array}$ \\
\hline $\begin{array}{l}\text { Significado, Sentimento de competência e Criação } \\
\text { de sentido e significado }\end{array}$ & $\begin{array}{l}\text { Contextualização com jogos digitais } \\
\text { com os smartphones no contexto escolar }\end{array}$ \\
\hline Autorregulação e controle de comportamento & $\begin{array}{l}\text { Possibilidades de acompanhamento } \\
\text { de suas autoaprendizagens } \\
\text { e encontrar alternativas de superação }\end{array}$ \\
\hline Mediação de conduta compartilhada & $\begin{array}{l}\text { Habilidades de compartilhar } \\
\text { colaborativamente experiências }\end{array}$ \\
\hline $\begin{array}{l}\text { Mediação das diferenças individuais, Sentimento } \\
\text { de Pertencimento }\end{array}$ & $\begin{array}{l}\text { Inclusão escolar, valorização } \\
\text { e legitimidade das diferenças de opiniões, } \\
\text { desejos, estilos de ser }\end{array}$ \\
\hline $\begin{array}{l}\text { Planejamento para Alcance de Objetivos, } \\
\text { Alternativa Otimista e Busca por Desafio }\end{array}$ & $\begin{array}{l}\text { Responsabilidade de executar } \\
\text { ações possíveis, aceitar mudanças, } \\
\text { flexibilidade }\end{array}$ \\
\hline Automodificação & $\begin{array}{l}\text { Percepção da necessidade de } \\
\text { aperfeiçoamento de desenvolvimento } \\
\text { de competências }\end{array}$ \\
\hline
\end{tabular}

O roteiro das atividades propostas com jogos digitais consistiu em:

1. Sondagem diagnóstica para detectar as dificuldades dos alunos em relação aos conteúdos de Matemática. Verificar com os alunos os jogos digitais que eles querem jogar que tenha relação com os conteúdos de Matemática que os alunos precisam trabalhar.

2. Indicar o jogo digital para os alunos jogarem livremente. Explicar brevemente o conteúdo do jogo e auxiliar os alunos a colocarem o jogo em seus dispositivos móveis.

3. Ficar a disposição para tirar dúvidas relacionadas ao jogo digital em questão, jogar com os alunos se possível. Criar grupos no WhatsApp e FaceBook para interagir com os alunos, e favorecer que os alunos compartilhem seus feitos em relação ao jogo.

4. Fazer a avaliação da experiência com grupo focal.

A atividade prevista nos jogos se resume a clicar nos menus para comprar, vender e executar tarefas em tempo real, características dos três jogos escolhidos pelos alunos, ou seja, SimCity BuildIt, Clash of Clans e The Sims FreePlay. As ações dos jogos escolhidos estavam diretamente ligadas ao uso de Matemática em relação ao HUD (Cap. 1.2,p. 9), como foi explicado anteriormente.

Os grupos focais procuraram usar elementos matemáticos implícitos e explícitos para fazer a ponte do que os alunos sabiam com os conteúdos curriculares da escola, incluindo a resolução de problemas contidos nas avaliações externas (SARESP e Prova Brasil).

Foi verificado que a linguagem multimidiática contida na narrativa possuía as competências cognitivas previstas na grade curricular da escola. No ato de narrar sobre o jogo digital, foi percebida uma motivação muito forte, os alunos se divertiam e demonstravam um interesse visível por narrar seus feitos, suas conquistas e até mesmo suas dificuldades para superar certos desafios. Os alunos 
utilizaram a linguagem do jogo para falar de suas experiências obtidas ao jogar com o professor e em relação ao que seus colegas também fizeram. Então, usar a linguagem do jogo, para fazer e explicar assuntos do currículo escolar, pode facilitar a comunicação dialógica entre docente e discente. Dessa forma, o professor pode utilizar o conteúdo de Matemática implícito e explícito contidos nos jogos citados para fazer a ponte entre o conhecimento criado pelo aluno e as competências curriculares de Matemática.

Em relação à presente investigação, a intencionalidade foi explicitada no dia que os jogos utilizados foram apresentados à turma. Na interação mediada, o conteúdo específico de articulação, como os pressupostos dos PCN, não foi levantado para os alunos, apenas para os professores, o que mostrava a intencionalidade da mediação apenas pelos jogos. Os alunos reconheceram o foco de habilidades matemáticas durante os grupos focais como alternativa inovadora de avaliação do conhecimento aprendido.

A intenção das atividades com os jogos digitais SimCity BuildIt, Clash of Clans e The Sims Freeplay foi a de avaliar quais conteúdos e competências cognitivas relacionadas ao raciocínio lógicomatemático eles seriam capazes de promover de maneira autônoma.

Quanto à reciprocidade, foi notada durante as visitas, registradas nos diários de campo, onde o pesquisador era sempre recebido na escola pelos alunos com emoções fortes como entusiasmo e contentamento. A possibilidade de usar jogos digitais favoreceu um ambiente cheio de motivação e interesse em ajudar nas atividades desenvolvidas pelo pesquisador, seja com sugestão de jogos digitais diversos ou tecnologias que poderiam ser usadas nas atividades.

O fato de os alunos perguntarem pelos pesquisadores e quando os mesmos começariam com os jogos, com ansiedade visível, além de perguntarem e pedirem para não ficar de fora do projeto, reforçou a percepção da reciprocidade antes mesmo da aplicação dos jogos. Para ilustrar o interesse dos alunos, estas notas de campo refletem o que foi dito. Diário de campo:

"Moisés - Iae bosco cade as atividades de games

Bosco - Tenho uma boa notícia, quarta feira eu vou na escola Fernando Nobre falar do jogo que vamos jogar, dar os detalhes e orientar vcs =)

Vinícius - Quando nós vamos começar a jogar os jogos?

Bosco- Ola, na próxima quarta, essa tem passeio né?

Cecilia - O prof bosco eu baixei no celular do me pai ta

Vinícius - Eu baixei foi no meu

Cecilia - Hm

Bosco- Tudo bem

Bosco- Espero que vcs gostem

Moisés - Professor procura no Google Play o jogo Clash of clans! Muito maneiro

Bosco - Vou procurar". retirado do Whatsapp.

A Transcendência, segundo item presente no Quadro 5.1, foi percebida de maneira nítida. A capacidade de compreensão do alinhamento dos conteúdos matemáticos de Álgebra I, Geometria 
Analítica e Aritmética das aulas tradicionais com as situações vivenciadas, com autonomia e liberdade, na construção das cidades ou na criação das estratégias possíveis, realizadas nas atividades presentes nos jogos, foram registradas nos diários de campo e nos grupos focais:

"Stela - Um de vocês me responda o que era o jogo?

Moisés - Eu acho que o jogo serve para mostrar seu desempenho seu cuidado seu raciocinio

Stela - Ah é?

Moisés - é como que você vai fazendo porque tipo lá você começa com uma quantidade de dinheiro ai você tipo tem que fazer como gastar aquele dinheiro dá pra tudo que você quer, ai é uma questão de estratégia como que você cria suas coisas...

Stela - e você percebeu tudo isso?

Moisés - sim," (grupo focal - 12/11/15)

"Daniel - aprendemos a trabalhar com gráficos também por causa do nosso dinheiro pra fazer nosso balanceamento

Stela - E eu ouvi

Vinícius - Administração

Stela - vocês trabalharam com gráfico?

Daniel - é porque...

Stela - então vocês tiveram que conhecer, elaborar ou calcular?

Vinícius - tudo.

Stela - tudo?

Vinícius - é porque tipo a gente teve que pensar como a gente ia melhorar o quartel, mas primeiro tinha que melhorar o negócio de ouro. mas pra melhorar o negócio de ouro você tinha que ganhar mais ouro" (grupo focal - 01/06/2016)

Os alunos, a pedido do pesquisador, resolveram os problemas matemáticos na lousa de giz, conforme imagens presentes no Apêndice $\mathrm{J}$ e áudios registrados e transcritos nos grupos focais (Apêndice L). Os problemas matemáticos propostos foram similares aos descritos na seção 5.1. Os alunos resolveram de cabeça a primeira questão, porém foram incentivados a tentar formalizar matematicamente suas respostas usando o elemento incógnita "X", nomenclatura desconhecida por todos. Foram estimulados a resolver problemas a partir do contexto dos jogos SimCity BuildIt, Clash of Clans e The Sims FreePlay, de forma colaborativa. Após essa questão, outras mais difíceis foram sugeridas no quadro e os alunos, após algum momento de reflexão, conseguiram também resolver por meio de equações, trocando sugestões, colaborando e cooperando com outros colegas que estavam tentando resolver os problemas propostos. Perceberam que o que estavam tentando resolver era muito semelhante ao que eles pensavam para tomar as decisões no jogo. A partir da segunda questão, houve uma comoção dos alunos para tentarem se ajudar mutuamente. Cada grupo apresentava uma ideia diferente de como resolver o problema. Ao final, os alunos apresentaram duas formas diferentes de resolução, diante de grande entusiasmo. 
Os jogos contêm um contexto, linguagem e ambientação que tornou fácil a manipulação de ideias, explicações e elucidações de problemas matemáticos criados como desafios para testar as habilidades de resolver equações de primeiro grau. Foi mais inteligível para os alunos a contextualização de um problema matemático usando o jogo como contexto do que usar exemplo qualquer contido no livro base da escola, com questões que não fazem parte do seu cotidiano. Para ilustrar esta afirmação, tem-se o registro dos alunos que acertaram uma questão sobre cálculo de área contextualizada com a linguagem dos jogos Clash of Clans e The Sims Freeplay, e, por último, a mesma questão da Prova Brasil. Porém, todos os alunos erraram ou deixaram em branco a mesma questão da Prova Brasil, que fora realizada antes da aplicação do grupo focal.

A transcendência que foi observada extrapolou as questões do raciocínio matemático, envolvido no jogo, para questões e resolução de problemas relacionados ao papel de um cidadão em sua cidade. Os alunos foram capazes de transferir o que foi aprendido para outras áreas da vida.

Um aluno relatou sua percepção da preocupação com a administração do lixo, fazendo uma relação com um jornal local cuja matéria falava sobre lixo acumulado num terreno baldio, conforme ilustrado na transcrição abaixo. O aluno discutiu sobre a importância da administração do lixo na prevenção de doenças como a dengue e relacionou-a ao jogo e a como tratava o lixo no mesmo.

"Vinícius - a gente também tem que ouvir os balãozinhos da população, porque as vezes eles pedem pra ter mais vizinhos, as vezes tem que fazer, melhorar a energia quando está faltando, dão presentes pra aprimorar o armazém.

Stela: Então vocês acham que por exemplo na nossa cidade temos políticos responsáveis? Eles ouvem os moradores?

Daniel - Não

Vinícius - eu vi no jornal que perto de um condomínio, tinha logo um terreno e nesse terreno só tinha lixo, jogava lixo lá e por causa desse lixo, é... tinha um monte de dengue lá ai trazia perigo lá pro condominio.

Stela: então isso faz parte do saneamento básico, a questão do lixo e da poluição, né? Muito bom." (grupo focal - 12/11/2015)

No Clash of Clans a transcendência, além das competências de matemática, foram observadas nos cuidados com a aprendizagem de símbolos e significados contidos no jogo, que não são comuns à realidade da vida dos alunos, como a palavra "gema", "elixir", "cultura nórdica", dentre outros conceitos.

"Stela - uma preciosidade não é isso? que que eu faço com a gema? como recurso? que que a gema deixa eu fazer?

Vinícius - é... acelerar as coisas ou comprar o negócio pra cabana do construtor.

Stela - acelerar ou então acabar alguma coisa que você está construindo

Vinícius - é...

Moisés - é porque, eu estava lendo num site lá esses dias e... a gema na verdade é para você pagar o construtor, porque ele não vai trabalhar de graça, ai tipo pra você terminar uma construçấo é 250 gemas, ai ao invés de você esperar o tempo, você paga isso em gema. 
Stela - era outro costume diferente do que a gente tem hoje, então que vocês levam pra vida de vocês com esta experiência. Do jogo, pra gente fazer uma relação entre problemas da matemática?

Gustavo - tudo que você usava, você tem que pagar pro dono do feudo, o senhor feudal, por exemplo se fosse usar o moinho tem que pagar a taxa pra usar lá...

Stela - está dizendo que no jogo pra usar o moinho, alguma situação que você viu você pode trazer ela pra vida de hoje. Pode falar [...]" (grupo focal - 01/06/16)

No diálogo das entrevistas individuais, bem como nos diários de campo, foi possível notar a transcendência no uso dos jogos digitais favoritos citados pelos alunos, e como eles possivelmente usam o conhecimento obtido pelos mesmos em outras áreas da vida. O fato de como os alunos organizavam e dialogavam sobre certos assuntos tratados, e suas ideias, a partir do contexto citado pelos alunos na entrevista, ajudaram a perceber tal competência. Os alunos foram capazes de antecipar acontecimentos futuros direcionados por ações e decisões tomadas a exemplo do que fizeram nos jogos.

Percebeu-se que a transcendência pode ser trabalhada em cima de questões sociais como a sexualidade, pois o conteúdo e contexto do jogo digital The Sims FreePlay contém a possibilidade de administração de diversos tipos de relacionamentos. Uma professora da escola, que estava acompanhando, percebeu que pode-se trabalhar textos, interpretação, descrição e narrativa, entre outros fatores, usando as explicações das experiências do uso de jogos digitais, comunicou que ficou interessada e pediu auxílio para o uso de jogos digitais em suas atividades.

Durante uma das visitas, o pesquisador ajudou os alunos a transcenderem através da mediação de um diálogo sobre a ética, pois um grupo de alunos sugeriu utilizar artifícios externos ao jogo de modo a obter vantagens, infringindo as regras do mesmo. Ao fim os alunos concordaram com o pesquisador, que com a transgressão das regras, poderia comprometer o objetivo das atividades com jogos digitais e ajudaram o mediador a relacionar tais questões com problemas do mundo real, como a corrupção.

Quanto à questão 3 do Quadro 5.1, sobre significado, foram trabalhadas nos grupos focais com perguntas como: "O que vocês aprenderam com este jogo? Como resolveram os problemas do jogo? Por que este conteúdo é importante e precisa ser aprendido?". Favoreceram-se respostas que transferiam o aluno para situações vivenciadas em seus contextos sociais. Configuraram-se como uma espécie de capacidade energética, que constitui um motivo para aceitar e absorver a mediação. A mediação do significado das ações e objetivos dos jogos criou motivação para a mediação dos alunos, confirmando a MCE e impulsionando as atividades para que o aprendizado se tornasse significativo. A construção do significado fez com que os alunos entendessem a mensagem expressa pelo jogo digital, assim como a de seus colegas, de forma coletiva e colaborativa. Conseguiram racionalizar sobre ela e, ao estender para os conteúdos curriculares da Matemática, entenderam o registro formal mais complexo, pois o jogo viabilizou a aplicação de tais conceitos de maneira suave e implícita, conforme percebemos na transcrição retirada do grupo focal:

"Stela - E você do lado, que que você achou do jogo? o que mais te chamou atenção? Moisés - Tipo pra se divertir assim e a mesma coisa que ele pra na administração de seu dinheiro lá no jogo, se você gastar tudo você não consegue fazer mais nada, tipo... 
Cecılia - eu achei o jogo legal, porque ele ensina bastante coisa e... é meio difícil quando comandar o dinheiro pq tem coisa que a gente precisa mas não tem dinheiro suficiente pra gente comprar e a nossa cidade acaba pegando fogo (risos, dela e de colegas)

Stela - Você pode ter uma noção de como é difícil ser prefeito de uma cidade. Imagina a grande são paulo que tem 25 milhões de pessoas, imagina, água esgoto pra todo mundo...

Vinícius - eu achei legal porque ensina a administrar o dinheiro, o meu eu não consegui administrar porque eu achei muito difícil (risos) ai eu fiquei só com 15, eu fiquei com mais moeda que o dinheirinho verde lá." (grupo focal - 12/11/2015)

Os alunos demonstraram a profunda construção de significado em áreas complexas da tecnologia de informação, informática e computação, e no uso da Matemática em suas vidas ao comentarem sobre as atividades realizadas para solucionar cooperativamente os problemas encontrados nos jogos digitais. Foi possível observar que os alunos, ao se ajudarem mutuamente nos jogos digitais, constroem significado e, ao compartilhar informação, reforçam os significados presentes no contexto do jogo. Os alunos explicam, com sua própria didática, como fazer determinadas tarefas, por que fazer e quais os seus possíveis resultados. O engajamento dos alunos gera a construção de significado tanto dos conteúdos quanto das relações emocionais. Aqui o significado que o jogo tem, em sua cultura, é para fugir de sua realidade, diversão e confraternização com os colegas. O jogo tem o sentido de fazer se sentir bem em meio a sua realidade e também a construção de significados e conceitos de conteúdo para além da grade curricular.

Outros fatores, como sentimento de pertencer a um grupo, pois no jogo eles são um clã, sentimento de competência, pois se sentem competentes para realizar tarefas complexas, intencionalidade e reciprocidade, pois ao ajudar os colegas eles deixam claro suas intenções como indivíduo e como grupo, o desafio implícito de ter maiores níveis e uma cidade maior que os colegas, ajudavam no desenvolvimento desta competência, bem como a ajuda do mediador e dos outros colegas para superar desafios.

Percebeu-se que os alunos têm um forte sentimento de competência, o que favorece superar obstáculos. A professora relatou, durante as visitas feitas pelo pesquisador, que as atividades do uso de jogos digitais tornaram os alunos mais alegres e confiantes para tentarem resolver desafios e questões matemáticas em sala de aula.

Foi observado o comportamento dos alunos em executar tarefas com confiança, pois suas estratégias de administração de recursos, ataque e defesa estavam cada vez mais eficientes, apresentando resultados cada vez melhores. O ato de compartilhar tais informações com os colegas reforçou essa competência. No The Sims Freeplay os alunos também apresentaram o comportamento similar, executando as tarefas do jogo, com a troca de conhecimento entre jogadores e diversão em ver os resultados de suas escolhas. Foi registrado no diário de campo que uma das alunas falou sobre sua casa, quanto de dinheiro tinha conseguido acumular e como tinha feito sua casa, comprado móveis e redecorado. Outras alunas também falaram e mostraram suas casas. Compreenderam que os jogos podem ensinar e não apenas para o lazer. Podem ensinar, motivar e alegrar suas vidas.

"Marcelo - aí também tem que ver lá que é... que aí pra testar suas qualidade, que ai você constrói suas casas ai tem os moradores ai tem vezes que aparece uma bolinha lá com a carinha vermelha, pq está ruim morando perto de fábrica.

Stela - e seu colega do lado? Você gostou do jogo? 
Marcelo - Gostei

Stela: Por quê?

Marcelo - Por causa que.. é... ensina a economizar e tudo isso que ele falou também, que sê vai aprender a melhorar a cidade com o tempo mas não gastando tanto,

Stela - Você fica responsável pela sua cidade.

Marcelo - Você fica responsável pela sua cidade.

Stela - Voce pela sua e ele pela dele?

Marcelo - Sim pq eu sou prefeito né? ai aparece umas bolinha vermelha ai quando ta triste ta muito perto das fabricas ai tem que trocar eles de local e gastar mais na cidade." (grupo focal - 12/11/2015)

Pode-se perceber a autorregulação e o controle do comportamento pelas conversas entre pesquisadores e relato dos professores, onde os alunos se regulavam ao responder, quando tinham a resposta fácil na ponta da língua, ou quando não pensavam, refletiam, construíam as frases ou consultavam seus colegas para conferir os dados e então respondiam aos pesquisadores. Os alunos, ao se depararem com uma provocação cognitiva sobre alguma ação do jogo, não respondiam de imediato, restringiam-se a um tempo para pensar, racionalizar e/ou analisar os dados e se possuíam os dados necessários a serem processados antes de responder ou participar do diálogo. No Clash of Clans os alunos explicaram como planejavam a construção de suas vilas, para que ficassem protegidos de ataques dos inimigos e como planejavam seus ataques, seja individual ou em grupos, nas guerras de clãs.

"Stela - então vocês tiveram que conhecer, elaborar ou calcular?

Moises - tudo

Stela: tudo? então vou por aqui.

Moises - é porque tipo a gente teve que pensar como a gente ia melhorar o quartel, mas primeiro tinha que melhorar o negócio de ouro. mas pra melhorar o negócio de ouro você tinha que ganhar mais ouro

Stela - ah então o que você ta fazendo, o que você fez foi relações?

Moisés - é

Moisés: é não Vinícius? você tem que pensar, tipo, você quer melhorar o centro de vila dai você tem que ter dinheiro, aí não adianta nada você ter o dinheiro que você vai ter que melhorar o depósito que guarda o ouro."(grupo focal - 01/06/2016)

Os alunos falaram sobre a importância da estratégia na hora de construir a tropa, escolhendo quais unidades construir e qual a função na guerra de cada tropa. Sendo assim, havia momentos de tomada de decisões rápidas em uma guerra, de acordo com as eventualidades, ou planejando coleta e gasto de recursos nas construções a longo prazo. Os alunos se regulavam ao falar sobre suas escolhas de jogo, ao explicar aos colegas suas escolhas ou dar suporte a um colega que pedira ajuda. Existem momentos nos jogos em que se precisa de tomada de decisões críticas, com um curto intervalo de tempo, ou decisões não críticas, que não demandam esforço cognitivo, e também 
existem decisões em que os alunos consultam os colegas, sites na internet e fóruns das comunidades dos jogos, para maximizar o sucesso das suas decisões no jogo.

"Stela - quem colaborou com quem? quem ajudou, quem aqui tava jogando ai veio outro e perguntou como você fez isso e tal? ai você deu dicas?

Moisés - Ajudei o Vinícius.

Vinícius - eu não sabia como fazer, eu sabia como arrastar os negócio lá. Ai pedi umas dicas ele deu uns toques assim." (Grupo Focal - 08/06/2016)

Os alunos, ao tentarem resolver questões matemáticas, demonstraram certa dificuldade de autorregulação, mas após o mediador ajudar a controlar a ansiedade e organizar suas ideias a solução do problema proposto foi alcançada. Neste caso, o mediador tem um papel essencial e deve estar sempre atento para ajudar na organização mental do aluno de modo que este consiga desenvolver um pensamento crítico.

Ao longo das visitas, realizadas para a mediação das atividades com jogos digitais, pôde-se notar um avanço significativo na autorregulação e controle do comportamento, onde os alunos ficaram concentrados, focados, e quase não ocorreu nenhum tipo de interferência ou desordem. O pesquisador conseguiu jogar com os alunos sem precisar se esforçar no sentido de manter a ordem, uma vez que essa turma, $9^{\circ}$ ano b, sempre demonstrou ansiedade e inquietude, sendo que antes eram necessárias várias intervenções da professora e pesquisador para manter a turma comportada.

No SimCity BuildIt os alunos relataram que havia sempre a preocupação em conter gastos e não ficar sem dinheiro, para que conforme os problemas da cidade fossem surgindo tivessem recursos para construir mecanismos que pudessem sanar tais problemas, dessa forma raciocinavam e controlavam seus impulsos, para economizar dinheiro. Além disso, sempre havia a preocupação de buscar formas alternativas de obtenção de recursos, conforme ilustrado pelo trecho retirado da transcrição do grupo focal abaixo:

"Stela - O que que você, por exemplo, lembra de uma época, uma situação que você estava em casa pensando, estava jogando, deu uma parada olhou pro alto, falou: hum, meu deus, como eu faço isso aqui? você fez algum cálculo, algum plano? você pensou como eles?

Gustavo - quando... teve uma vez que estava pedindo pra comprar uma fábrica e uma casa, ai eu pensei, parei e comprei a fábrica, porque lá produz os materiais que eu vou precisar pra fazer a... pra melhorar a casa depois, e quando tem bastante material tem gente que quer comprar ai eu vendo, consigo dinheiro e compro a casa." (grupo focal $12 / 11 / 2015)$

Essa competência começou a ser explorada com intencionalidade e reciprocidade, além do significado de aprender e compartilhar informação, dúvidas e sugestões por meio de redes sociais utilizadas nesta pesquisa. Então grupos para facilitar a comunicação e o compartilhamento foram criados tanto no Facebook quanto no WhatsApp. Foi incentivado que os alunos conectassem suas contas dos jogos em questão com o Facebook, para que pudesse haver cooperação e ajuda, além de facilitar os colegas, professores e o pesquisador a visitar suas cidades para acompanhar a atividade com uso de jogos digitais. 
Além dos jogos digitais, o uso dessas redes sociais favoreceram a habilidade de fazer contato dos alunos com seus colegas, professores e pesquisadores, com objetivo de complementar a comunicação de dúvidas, sucessos e conquistas alcançadas, ficar próximos uns dos outros e criar harmonia entre experiências compartilhadas. O desenvolvimento desta competência favoreceu oportunidades de adaptação dos alunos e professores, não se limitando ao aspecto emocional e/ou afetivo. Existe nela o potencial de enriquecer o desenvolvimento cognitivo. O receptor/transmissor do que é transmitido participa no que é significativo para o outro receptor/transmissor, confirmando suas experiências. Quem transmite ora reforça a experiência vivida para outros, ora reforça o significado e integridade de sua experiência.

O pesquisador percebeu que o comportamento de compartilhar em jogos digitais extrapola o conhecimento básico do aluno. Um grupo de alunos, sob supervisão do mediador, compartilhou informação em tempo real durante o grupo focal, de forma a obter cooperação para solucionar problemas matemáticos. Tais desafios propostos de forma abstrata, ao serem solucionados em equipe, ajudaram a promover conhecimento e a desenvolver pensamento crítico.

Essa competência sempre esteve presente, seja nas conversas presenciais com alunos durante as visitas à escola, bem como nas redes sociais utilizadas neste trabalho. Além disso, os jogos escolhidos possuem recursos de compartilhamento de informações, tropas, personagens, cenários etc., onde os alunos vendiam mercadorias e tinham acesso às cidades dos colegas e do professor mediador da atividade. No Clash of Clans os alunos sempre mantinham uma troca grande de informações para ajuda mútua nas guerras de clãs, seja no Whatsapp ou no chat do clã no jogo. As trocas contemplaram dúvidas, dicas, sugestões de estratégias para mudanças de níveis, conquistas e desafios:

"Stela - Carlos, e você deu dicas pra ele com alegria? você achou legal quando vieram perguntar?

Carlos - sim

Stela - então essa atividade que eu sei que vocês tiveram, vocês desenvolveram na verdade,

Carlos - sabedoria?

Stela - colaboração, que que é colaboração?

Carlos - ajudar..." (grupo focal - 08/06/16)

O exercício com jogos digitais nesta pesquisa revelou que a consciência dos alunos quanto à legitimidade das diferenças de opiniões, tendências, desejos e estilos, sem necessariamente aceitar isto, representa uma condição importante para um processo adequado de individualização, sexto item do Quadro 5.1. A valorização das diferenças entre eles, entre os personagens do jogo e seus comportamentos únicos, levou à formação de percepção distinta e aceitável com relação a outros. Por esta razão, condenaram alguns dos comportamentos estratégicos do jogo Clash of Clans e de seus personagens. Por outro lado, quando questionados sobre comportamentos mais adequados e/ou responsáveis, como os de um prefeito na construção da cidade no jogo SimCity BuildIt, pode-se perceber o papel da escola no desenvolvimento de uma personalidade menos egoísta, arrogante e egocêntrica, que não identifica seus limites. 
Cada aluno teve um papel específico e único dentro dos jogos digitais, cada um possuía sua própria cidade no SimCity BuildIt, vila no Clash of Clans, ou suas famílias no The Sims Freeplay. Os alunos demonstravam com satisfação seus feitos e os resultados de suas ações no jogo, de maneira saudável e ajudando os colegas a construírem suas próprias construções, compartilhando os progressos individuais e os conhecimentos originados tanto do sucesso quanto do insucesso em cooperação, para maximizar os resultados do grupo como um todo.

No jogo digital Clash of Clans, os alunos criaram suas vilas e tiveram a oportunidade de testar suas próprias estratégias, baseadas nos seus conhecimentos prévios. Sentiram-se parte de um clã, com sua devida importância para o desempenho do grupo como um todo. Com acompanhamento da mediação, os sentimentos de abandono foram evitados. O grau de confiança individual foi desenvolvido junto com o desenvolvimento cognitivo, conforme pode-se observar nos trechos mais evidentes extraídos dos grupos focais:

"Miguel - sei lá eu queria competir com meu irmão, meu irmão também joga.

Stela - então ele queria competir, ele estava na emoção, isso é uma qualidade como cidadão é importante.

Miguel - professora, a emoção de jogar." (grupo focal - 01/06/16)

Houve um registro, num diário de campo, onde um aluno falou que outro era "burro" por não aceitar sua opinião que estava certa. Essa competência, se não for mediada corretamente, pode levar a esse comportamento. Conforme citado no referencial teórico, o pesquisador pode constatar o acontecimento registrado in loco e contornar a situação, fazendo uma intervenção adequada.

Os alunos ficaram livres para executar a criação e a administração de suas próprias cidades, podendo explorar seus conhecimentos prévios e julgamento do que consideravam certo ou errado, priorizando as escolhas das suas ações para com a cidade. Favoreceu a mediação das diferenças individuais, onde os alunos fundamentavam suas escolhas, com autonomia e liberdade, em suas experiências de vida e noções básicas de moral, ética e bem-estar e em seus valores culturais.

"Bosco - Na hora que tu tinhas que por exemplo construir um parque, tu tinha que
construir uma delegacia e outra coisa, mas ai tu tinha um dinheiro lá, como é que tu
fazia? Moisés - ah, entendeu, tipo, eu, vamo supor, se eu tivesse que construir um parque e depois vamo supor uma fábrica, ai eu tinha pouco dinheiro, vamos supor uns 6.000, ai eu tipo não ia poder construir a fábrica porque era mais importante.

Vinícius - quando teve uma vez que estava pedindo pra comprar uma fábrica e uma casa, ai eu pensei parei e comprei a fábrica, porque lá produz os materiais que eu vou precisar pra fazer a... pra melhorar a casa depois, e quando tem bastante material tem gente que quer comprar ai eu vendo, consigo dinheiro e compro a casa." (grupo focal - 12/11/15)

O sentimento de pertencer implica a ideia da inclusão, seja no elo familiar, na cultura ou num grupo de amigos. Os alunos pertencem a uma cultura digital onde os jogos digitais estão inseridos. Os alunos pesquisados fazem parte de uma comunidade onde estão presente alunos com sérios problemas financeiros e sociais, de diversos tipos, que não puderam ser aclarados por motivos de 
impossibilidade de acessar tal informação. Tais problemas levam à exclusão social e sentimento de não pertencer a sociedade ou grupos sociais.

O fato de os alunos perceberem estar sendo assistidos por um grupo de pesquisadores de fora provocou uma mudança de comportamento e um sentimento de pertencer entre eles, como grupo, e na inclusão que os pesquisadores trouxeram. Esse fato foi notado desde o dia do primeiro diário registrado.

Os professores envolvidos no projeto também demonstraram o sentimento de pertencer enquanto participantes nas experiências de aprendizagem mediada desenvolvidas neste projeto. Este fato foi notado tanto nos diários de campo quanto em algumas entradas no Moodle (Apêndice H) criado para assistir essa escola.

Os alunos discorreram sobre a comunidade de jogos digitais a que faziam parte quando jogavam com seus colegas cooperativamente ou competitivamente:

"Stela - vocês desenvolveram então o sentimento ó, vocês se sentiram, pertencimento, pertença, o que que é me sentir pertencente ao grupo, é bom?

Daniel - sim

(varios) (aceno com a cabeça para dizer sim)

Stela - eu to vendo aqui muitos meninos de boné por exemplo, e alguns tiraram o boné, to vendo alguns com tênis parecidos, né? e o fato de você jogar o mesmo jogo ter uma conversa comum é bom?

(varios) (aceno com a cabeça para dizer sim)

Stela - ou é melhor você se sentir sozinho e as pessoas não te aceitam por que você fica só com seus jogos lá, com suas coisas, é bom ter esse momento assim aqui na escola com a Roseli, conversar sobre a mesma coisa, vocês se sentem pertencendo a um grupo?

(varios) (aceno com a cabeça para dizer sim)" (grupo focal - 08/06/16)

Ficou claro que se o aluno não se sente inserido no contexto da atividade, no caso não gostar de um tipo de jogo digital, ou de um título específico, a EAM fica comprometida. Vale salientar que a experiência mediada executada nesta pesquisa é voluntária, e eventualmente era reforçado ao aluno que, caso ele não quisesse mais participar, ele era livre para não executar as atividades propostas, diferente do que acontece normalmente durante a execução das tarefas rotineiras tradicionais dentro de sala de aula, onde os alunos não têm escolha. Fica claro que a vontade de participar, sua motivação em continuar nas atividades com jogos digitais e o sentimento de pertencer a este grupo e cultura são importantes para o desenvolvimento e progresso dos alunos, como grupo e como indivíduos.

O grupo que fazia parte do Clã no jogo Clash of Clans possuía identidade e nome, e, dessa forma, eles se sentiam parte de um grupo, além do sentimento de fazer parte do grupo da escola nas atividades com jogos digitais. O sentimento de pertencer a um grupo, onde cada um tem um papel importante nas guerras dos clãs, também foi evidente nas redes sociais, compartilhando responsabilidades e deveres para ataques e defesas na guerra ou fora dela. Suas vilas tinham uma organização pessoal onde cada aluno construía e planejava estratégias de defesas e ficava contente com a pontuação e o avanço de nível de suas cidades.

O jogo The Sims FreePlay oferece o recurso de visitar a casa e a família do colega quando conectado na internet, por esse recurso foi possível, também, perceber que os alunos demonstraram 
o sentimento de pertencer quando um colega visitava a casa do outro, fazendo com que os jogadores se sentissem parte de um grupo virtual.

No SimCity BuildIt, contextualizado nas cidades, cada cidade pertencente a um jogador, que escolhe o nome e fica responsável por ela. O jogo é um universo lúdico de cidades e prefeituras, onde os alunos se sentiram incluídos e satisfeitos com o compartilhamento de experiências pessoais e responsabilidades passadas pelo jogo.

"Stela - Você fica responsável pela sua cidade.

Miguel - Você fica responsável pela sua cidade.

Stela - Voce pela sua e ele(A2) pela dele?

Miguel - Sim, pq eu sou prefeito né? ai aprece umas bolinha vermelha ai quando ta triste ta muito perto das fabricas ai tem que trocar eles de local e gastar mais na cidade." (grupo focal - 12/11/15)

"Luiza - tinha um jogo que eu jogava no celular do meu pai no mesmo estilo só que era o mesmo esquema, eu sou prefeito e tenho que cuidar da cidade, mas só que nessa cidade, os moradores não reclamavam era sua secretária que ia falar com você, e nessa cidade tem, tinha dia que eu tava jogando e eu esqueci de alimentar, de dar comida pro orfanato, ai veio a secretária e falou assim, os bebês do seu orfanato morreram

Stela $-e$ ?

Luiza - e ai que eu tive que fazer uma proclamação pra essa cidade, tipo falar que teve alguns cortes no orçamento que eu ia mandar de novo a comida pro orfanato, pra evitar que mais crianças morressem de fome.

Stela: mas você não recuperou esses bebês não é? Morreram mesmo, que pena, né?

Luiza - nossa eu fiquei muito mal." (grupo focal - 08/06/16)

As redes sociais envolvidas possibilitaram ainda uma maior inclusão e proximidade com os participantes, que trocam informações e ajudam-se mutuamente, além de pedirem ajuda para o pesquisador, que ficou responsável pelo desenvolvimento das experiências com as atividades dos jogos com os alunos.

Quanto ao sétimo item do Quadro 5.1, que é relacionado ao poder de abstração gerado em um indivíduo com um objetivo em foco, no seu repertório mental, os jogos por si só apresentavam um repertório de objetivos em potencial e estes podiam aumentar a esfera de consciência dos alunos com relação ao que é possível, desejável e alcançável. O pensamento crítico esteve sempre presente, já que os alunos, para alcançarem seus objetivos, apresentavam uma perspectiva de um futuro muitas vezes distante, algumas vezes demandando rejeição de gratificações imediatas (Simoleons no SimCity BuildIt e ouro no Clash of Clans). Tal fato pode criar, certas vezes, tensão entre a vontade, a necessidade e o suprimento dela, como, por exemplo, proporcionar o bem-estar dos moradores da cidade em construção.

A possibilidade de viver e experimentar, no pensamento abstrato, o que ainda não foi vivido, mas que é desejável, colocando objetivos a serem realizados no futuro, fez com que os alunos usassem formas abstratas do pensamento, a imaginação na representação do que ainda não existia. 
Este processo tem função extremamente importante na estruturação de operações mentais mais elevadas, que caracterizam a lógica do raciocínio matemático.

O pesquisador pôde observar in loco os alunos planejando ataques, defesas e administrando suas vilas no Clash of Clans, e no jogo The Sims FreePlay, com suas famílias, organização social dos personagens, construção e mobília da casa, pôde observar a organização e a administração financeira. O Clash of Clans, por se tratar de um jogo de estratégia de guerra, deixou evidente no grupo focal que o planejamento, o uso de estratégias, a criação de relações e de raciocínio crítico eram cruciais para que os alunos pudessem defender adequadamente suas vilas, bem como adquirir recursos para a compra de tropas, e, ainda, escalar as tropas para os ataques a outras vilas, ou as guerras em grupos.

"Stela - pensaram estratégias para solucionar problemas? vocês tinham problemas pra solucionar?

Miguel - mais ou menos porque que nem eu falei, vamos supor, a gente quer melhorar o CV ou quer melhorar sua vila, mas antes, você tem que melhorar o negócio de ouro.

Stela - Quer dizer que vocês pensaram em hipóteses? Hipótese é uma coisa que eu acho que pode ser melhor do que essa outra hipótese, vocês nunca ouviram essa palavra?

Miguel - eu já ouvi, mas esqueci o que é.

Stela - é uma ideia que você tem a princípio, só que você vai testar, né?

Miguel - você não sabe se vai dar certo ou errado..[...]

Stela - Você tem uma hipótese, uma ideia, me dá uma hipótese que você teve?

Miguel - que eu pensei?

Stela - é

Miguel - é que tipo, pra defender sua vila, eu pensei em defender minha vila, porque lá você contém uma quantidade de muros, tem que ir fazendo lá, ai eu tive que pensar pra saber onde eu tinha que proteger mais... ai pensei pra melhorar meu centro de vila, só que ai antes eu tinha que melhorar meu depósito de ouro.

Stela - isso é feito como, com cálculo, com raciocínio? como é?

Miguel - os dois" (grupo focal - 01/06/16)

No SimCity BuildIt ficou evidente que os alunos planejaram, priorizaram ações e usaram do raciocínio crítico para resolver problemas da cidade. Desde o início, a preocupação com a aquisição alternativa de recursos e dinheiro com o comércio de mercadorias produzidas nas fábricas do jogo, bem como o bem-estar da população, provia coletas maiores de impostos. Isto justifica, para ilustrar, a compreensão dos alunos sobre a relevância da compra de uma usina eólica, com maior benefício a longo prazo para o bem-estar da população, do que uma usina termoelétrica, que tinha um custo inferior.

"Stela - A poluiçãao, colocou poluição? A poluição pode ser sonora, né? Do ar, barulho, então não dá pra construir casa perto de fábrica, tem que ter algum mecanismo pra não fazer esse barulho, que mais? Eles reclamavam e ai vocês, você era o prefeito não é? Que que vocês faziam? 
Vinícius - Nós tinha que pegar a fábrica e levar pra outro lugar, deixar longe da cidade, Stela - isso, uma mudança, uma solução encontrada por ele é construir essas fábricas longe das casas, correto? Qual a outra solução que alguém encontrou?

Macros - construir uma coisa separada, como a usina de energia, tem a mais barata que faz muito barulho, e tem a eólica que é mais cara mas você pode deixar mais próximo.

Stela - então bem sempre, o barato as vezes sai caro não é?

(vários alunos) - Sim.., é.." (grupo focal - 08/06/16)

A essência dos jogos digitais explora a complexidade dos problemas e objetivos próprios conforme o jogador avança de nível, além de permitir que os jogadores explorem sua complexidade e ações alternativas para conseguir recursos para o jogo. Os alunos ficaram visivelmente encantados com a possibilidade de jogar em sala de aula, com o jogo digital em si, com a possiblidade de usar seu próprio dispositivo para se divertir e aprender e com a atividade em si, com pesquisadores da Universidade.

A experiência com o uso de jogos digitais favoreceu o desenvolvimento de alternativas otimistas pelos alunos. Assim como a busca por desafios, os alunos demonstraram que gostam de jogos digitais difíceis, que os fáceis demais logo perdem a graça. A complexidade presente nos jogos digitais, bem como seus desafios, são cativantes e atraentes para a vida dos alunos. Quando os alunos conseguiram perceber que existe uma diversão em uma determinada atividade, eles ficaram inclinados a buscar uma alternativa otimista.

A expectativa gerada pela possibilidade de uso de jogos digitais em sala de aula levou os alunos a aceitarem mudanças e desafios, e aumentaram sua prontidão para atacar fatores ambientais que ameaçavam seu equilíbrio físico e mental. Desta forma, permitiram-se desenvolver estratégias, em operações mentais, de situações encontradas que transcendiam para futuras soluções que serão vividas.

Foi possível perceber, ao longo das visitas à escola, registradas nos diários de campo e grupos focais, o entusiasmo, nítido nas expressões faciais e corporais e nas atitudes, além de toda emoção e empatia pela possibilidade do uso de jogos digitais, onde os próprios alunos, espontaneamente, demonstraram interesse em participar. O otimismo foi percebido, também, por parte dos professores e da coordenação da escola, onde uma das professoras demonstrou que já havia iniciado alguma tentativa de ludificar, ou usar jogos de tabuleiros para tentar motivar e ganhar a atenção dos alunos em sala de aula.

"Stela: Vocês gostaram desse jogo?

(vários alunos) - Sim!

Stela - Levanta a mão quem gostou.

(todos levantaram a mão)

Stela- e seu colega do lado? Você gostou do jogo?

Daniel - Gostei

Stela - Por que? 
Daniel - Por causa que.. é... ensina a economizar e tudo isso que ele falou também, que se vai aprender a melhorar a cidade com o tempo mas não gastando tanto," (grupo focal $-12 / 11 / 15)$

Os alunos estavam engajados em superar e buscar desafios cada vez mais complexos e difíceis. Notou-se que a curiosidade em descobrir novas características, desvendadas ao longo da superação dos desafios dos jogos, tem um potencial motivador, favorecendo a competência da busca por novidade e otimismo.

O Clash of Clans, por tratar de guerra e interação mais evidente e intensa com outros jogadores, acaba por ter sempre novidade e motivação para os alunos continuarem evoluindo e se fortalecendo, seja para defesa ou ataque. Já no Sim City BuidlIt, quando os alunos atingem níveis entre 25 e 30, o jogo deixa de apresentar novidade e demora alguns dias para que aconteça algo novo. Sendo assim, apresentou um ciclo de vida menor em relação ao Clash of Clans, que, mesmo depois das atividades desta pesquisa na escola, os alunos afirmaram que ainda jogarão por muito tempo, pois continua muito divertido.

A automodificação, sétima competência do Quadro 5.1, foi evidente, pois a natureza dos jogos digitais exige que o jogador aprenda para que supere os desafios que tendem a ficar cada vez mais difíceis, com cada vez menos suporte ou recursos. Foi percebido que os alunos modificavam suas opções no jogo para que pudessem compreender, desenvolver-se e aprimorar suas habilidades em busca de melhorar sua cidade e melhorar o bem-estar da população, assim como conseguir mais recursos e subir de nível, no SimCity BuildIt.

"Stela - Um de vocês me responda o que era o jogo?

Daniel - Eu acho que o jogo serve para mostrar seu desempenho seu cuidado seu raciocinio

Stela - Ah é?

Daniel - é como que você vai fazendo porque tipo lá você começa com uma quantidade de dinheiro ai você tipo tem que fazer como gastar aquele dinheiro dá pra tudo que você quer, ai é uma questão de estratégia como que você cria suas coisas...

Sela - e você percebeu tudo isso?

Daniel -sim" (grupo focal - 12/11/15)

No caso do jogo Clash of Clans, os alunos transformavam suas opções enquanto tentavam se adequar ao raciocínio do jogo, das guerras, dos clãs e do sistema de cooperação e competição, para que pudessem sobreviver, lutar, defender-se e, dessa forma, conseguir pontuação para subir de nível e evoluir suas vilas. No decorrer desta pesquisa os alunos ficaram mais inclinados a participar, conforme registrado nos diários de campo. Os alunos demonstraram uma evolução em suas habilidades de análise e síntese.

"Stela - A pergunta que eu faço pra vocês que jogaram é o seguinte, o que que vocês que jogaram aprenderam com esse jogo?

Telmo - posso? Eu, bom até agora que eu joguei eu aprendi que devemos ter uma forma de ataque, outra de defesa, e tipo ir pensando como que você vai gastar o dinheiro 
Stela - então você aprendeu a desenvolver estratégias?

Telmo - sim, defesa também

Stela - estratégias, e essas estratégias possuíam 2 posições, defesa e ataque, é isso? que mais vocês aprenderam? tem uma coisa que eu sei que vocês aprenderam, que vocês tiveram que fazer o cálculo

Telmo - mitologia nórdica," (grupo focal - 01/06/2016)

A automodificação acontece constantemente, para que o aluno, ao criar relações de significados aos símbolos dos jogos digitais, mesmo não relacionando-os ao conteúdo de Matemática, entenda e supere desafios e alcance os objetivos dos jogos digitais, alguns destes com complexidade elevada. Deve-se destacar que, neste ponto, cabe ao mediador tal responsabilidade, para ajudar a criar a ponte do que foi aprendido com o jogo e usar esse conhecimento para facilitar uma automodificação direcionada para áreas úteis de sua vida. Os alunos menos experientes se automodificaram ao perceberem o comportamento e os resultados dos colegas com níveis mais elevados de jogo. Foi possível também perceber que tanto os mais experientes quanto os menos experientes se adaptavam às necessidades para superar desafios, pois, no caso do Clash of Clans, é demandado trabalho em equipe, já que o jogo trata de guerra de grupos de jogadores.

\subsection{Relação dos jogos digitais escolhidos com a Matemática}

Uma análise dos conteúdos dos jogos digitais escolhidos foi feita como parte dos resultados desta tese. Nesta seção, será revelado como os conteúdos de cada jogo estão associados, direta ou indiretamente, aos conteúdos curriculares de Matemática, bem como exemplos de problemas matemáticos contextualizados aos jogos em questão.

\section{SimCity BuildIt}

Indiretamente, no jogo digital, se eu tenho 10.000 de gold e eu preciso comprar duas construções, 3.000 uma e 4.000 outra, eu tenho que entender algumas operações matemáticas como soma e subtração para saber se posso comprar ou não as duas estruturas pretendidas.

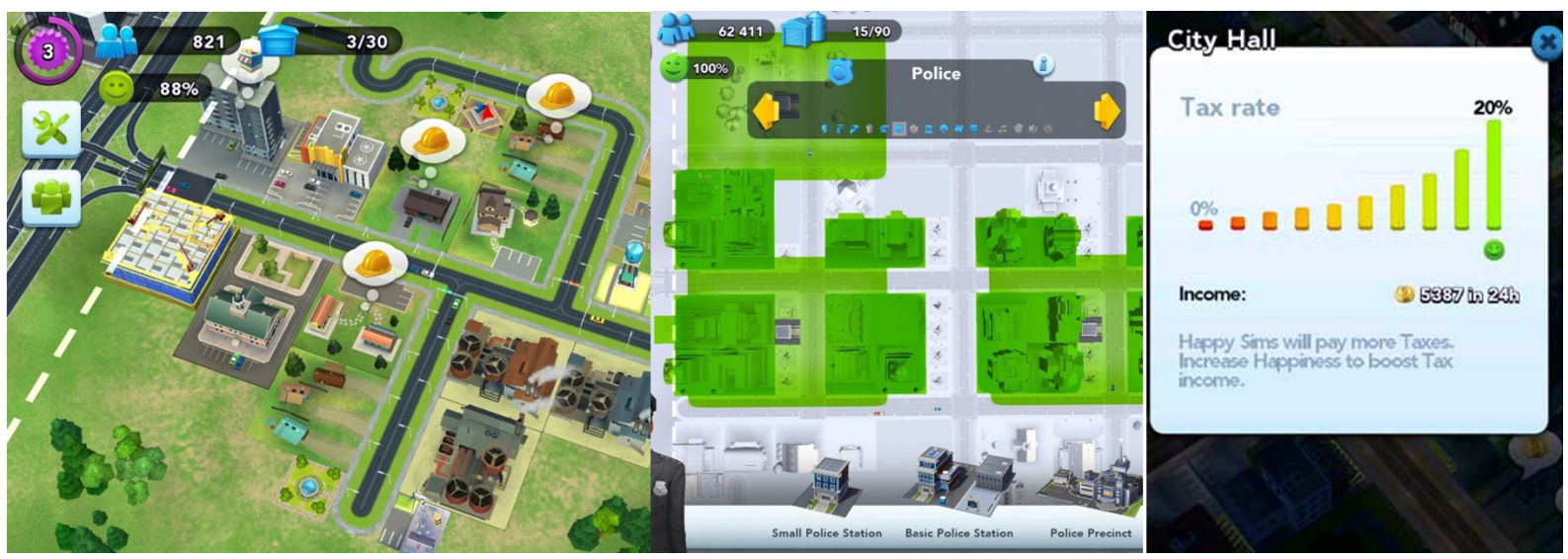

Figura 5.2: Visão principal do jogo com o HUD

O jogo contém a explicação de elementos próprios que são dados em sala de aula, como, por exemplo, os gráficos de barras, área, porcentagem entre outros, conforme ilustrado na figura 5.2. Na 
figura 5.3 o jogo explica que o gráfico está relacionado ao crescimento populacional e, ainda, que a construção de parques favorece tal crescimento.

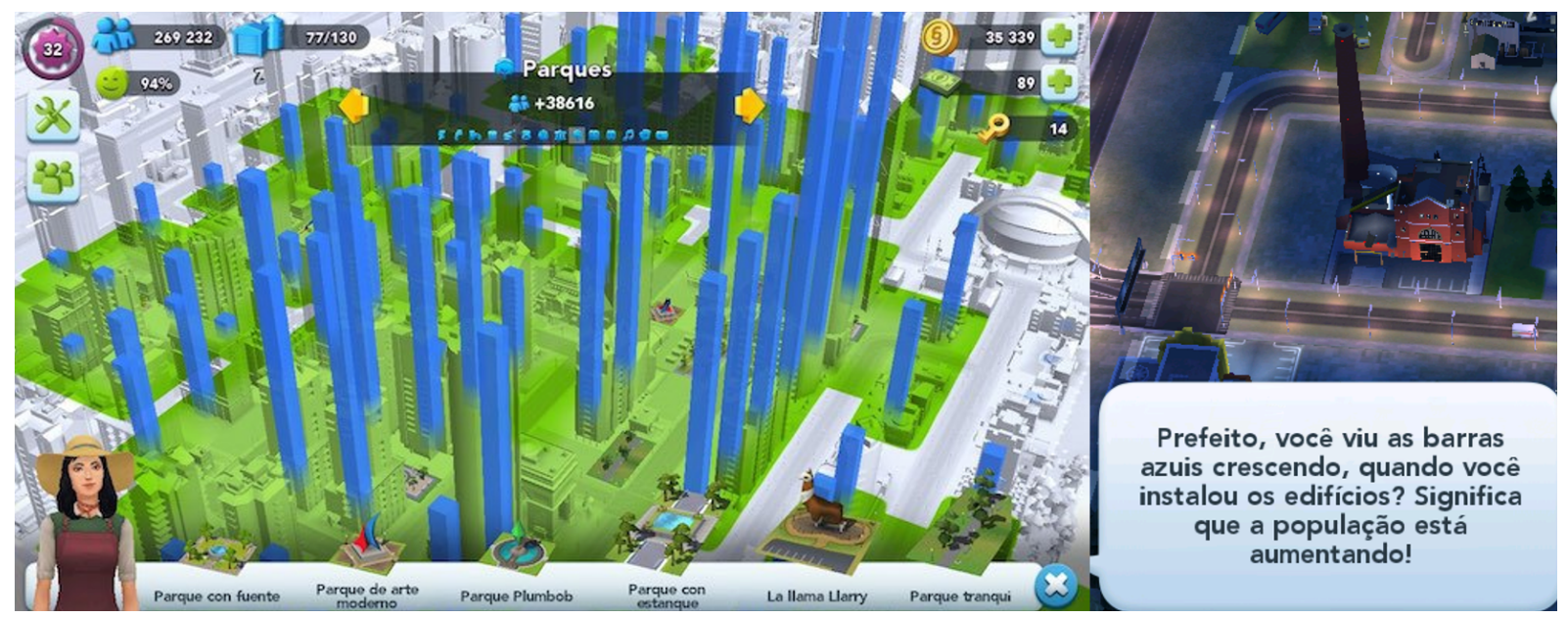

Figura 5.3: Gráficos do jogo em relação a satisfação populacional

Função polinomial do primeiro grau ou funções lineares podem ser trabalhadas indiretamente no jogo. Por exemplo, o professor pode fazer uma associação do crescimento populacional à coleta de impostos e tentar predizer, conforme a função linear, qual será o rendimento da cidade com o número populacional diferente.

Este jogo oferece oportunidade de construções como por exemplo, o de uma usina de tratamento de lixo e fábricas, entre outras, que possuem uma área de poluição. O aluno compreende o conceito de área pelas atividades do jogo e que podem ser trabalhadas relacionadas a problemas ambientais e assim por diante.

Qualquer operação matemática favorece a simulação de um planejamento da cidade, por exemplo:

\section{Equação do primeiro grau (álgebra):}

(a) Se cada casa contém 10 pessoas, quantas casas eu preciso ter para que a população chegue a 1.000 pessoas?

(b) Um aço demora 1 minuto para ficar pronto. Um prego precisa de 3 aços e mais 5 minutos para ficar pronto. Quanto tempo demora para eu criar 2 pregos, sendo que eu não tenho nenhum aço?

\section{Divisão (aritmética):}

(a) Se a cidade coleta 5.387 de gold a cada 24 horas, quanto a cidade coleta por hora?

(b) Se eu tenho 12.000 de gold e cada parque custa 4.000, quantos parques eu posso construir com esse dinheiro?

\section{Regra de 3 (aritmética e álgebra):}

(a) A população paga o imposto de acordo com a satisfação. Se a população paga 6.000 de imposto a cada 24 horas quando está $100 \%$ satisfeita, quanto a população pagaria em 24 horas se ela estivesse $80 \%$ satisfeita? 


\section{Cálculo de área:}

(a) Sabe-se que a poluição pode chegar a 200 metros de distância da fábrica e a 300 metros das usinas termoelétricas. Sabe-se também que, no jogo, a área da poluição forma um quadrado de lados iguais. Calcule a área total de poluição de 2 fábricas mais uma usina termoelétrica.

\section{Função polinomial, ou função linear:}

(a) Dado que a projeção de coleta de impostos no jogo pode ser descrita pela função linear ' $\mathrm{f}(\mathrm{x})=100 \mathrm{x}+20$ ', onde ' $\mathrm{x}$ ' é o número de habitantes e o resultado da função é a coleta de imposto, qual o gráfico formado por esta função? Quanto a cidade coletará com os seguintes números de habitantes: a) 100; b) 1050; c) 356 .

\section{The Sims FreePlay}

No jogo The Sims FreePlay também podemos verificar as mesmas características do SimCity BuildIt. Dessa forma, podemos criar as mesmas questões. Este é um jogo digital de simulação de vida, onde cada avatar tem seis barras de necessidades, são elas: fome; ir ao banheiro; dormir; asseio; socialização; e diversão. Neste jogo digital, o jogador controlar vários avatares e suas respectivas vidas, bem como visitar os avatares de outros jogadores que são amigos, através da conexão com o Facebook.

Na Figura 5.4, podemos ver alguns elementos como barras, porcentagem, área e assim por diante.

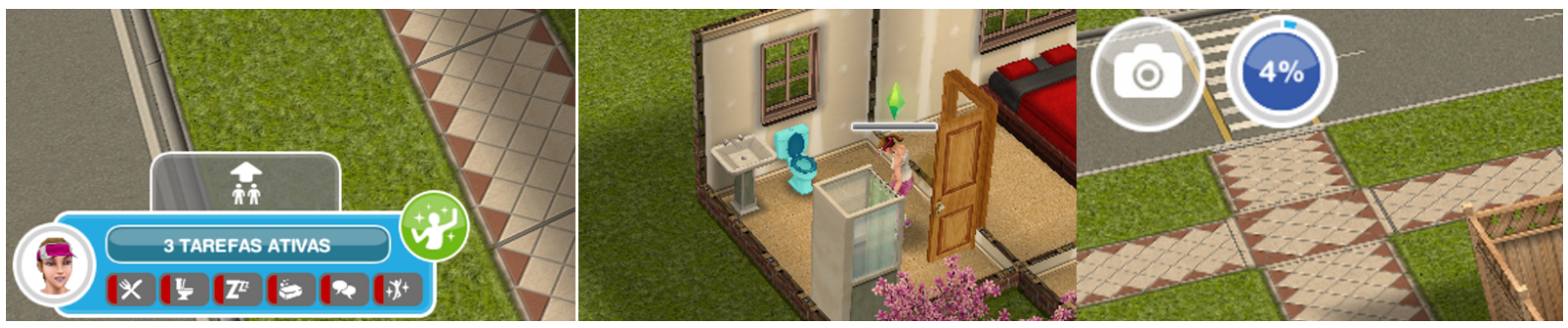

Figura 5.4: Barras de progresso de atividades

Os elementos da Figura 5.4, combinados com o contexto do jogo, podem ser utilizados para explicar conceitos do currículo escolar. A Figura 5.5 mostra o modo de edição onde o jogador pode construir ou reformar sua casa. Dessa forma, precisa ter noção de área, mostrada em uma grade de quadrados, para planejar e calcular os custos da obra, evitando que fique sem recursos antes de terminar a casa. A Figura 5.5 mostra alguns itens de mobília para casa. O jogador, além de construir a casa, tem que mobiliá-la de acordo com as necessidades do personagem, ou mesmo sua vontade de decorar a casa. Tudo isso tendo em mente que recebe um salário e suas ações podem levar a uma promoção, como na Figura5.6. Dessa forma, várias questões financeiras e de administração das finanças pessoais podem ser tratadas com esse jogo digital. São várias as possibilidades de relacionar tais elementos com os conteúdos do currículo de Matemática.

Na Figura 5.5 pode-se observar a vista da cidade e onde cada avatar mora, nesta visão é possível gerenciar os avatares e as construções da cidade. Tais construções servem como opção de lazer ou trabalho. De acordo com a evolução no jogo digital, mais locais são liberados. A Figura 5.5 mostra 


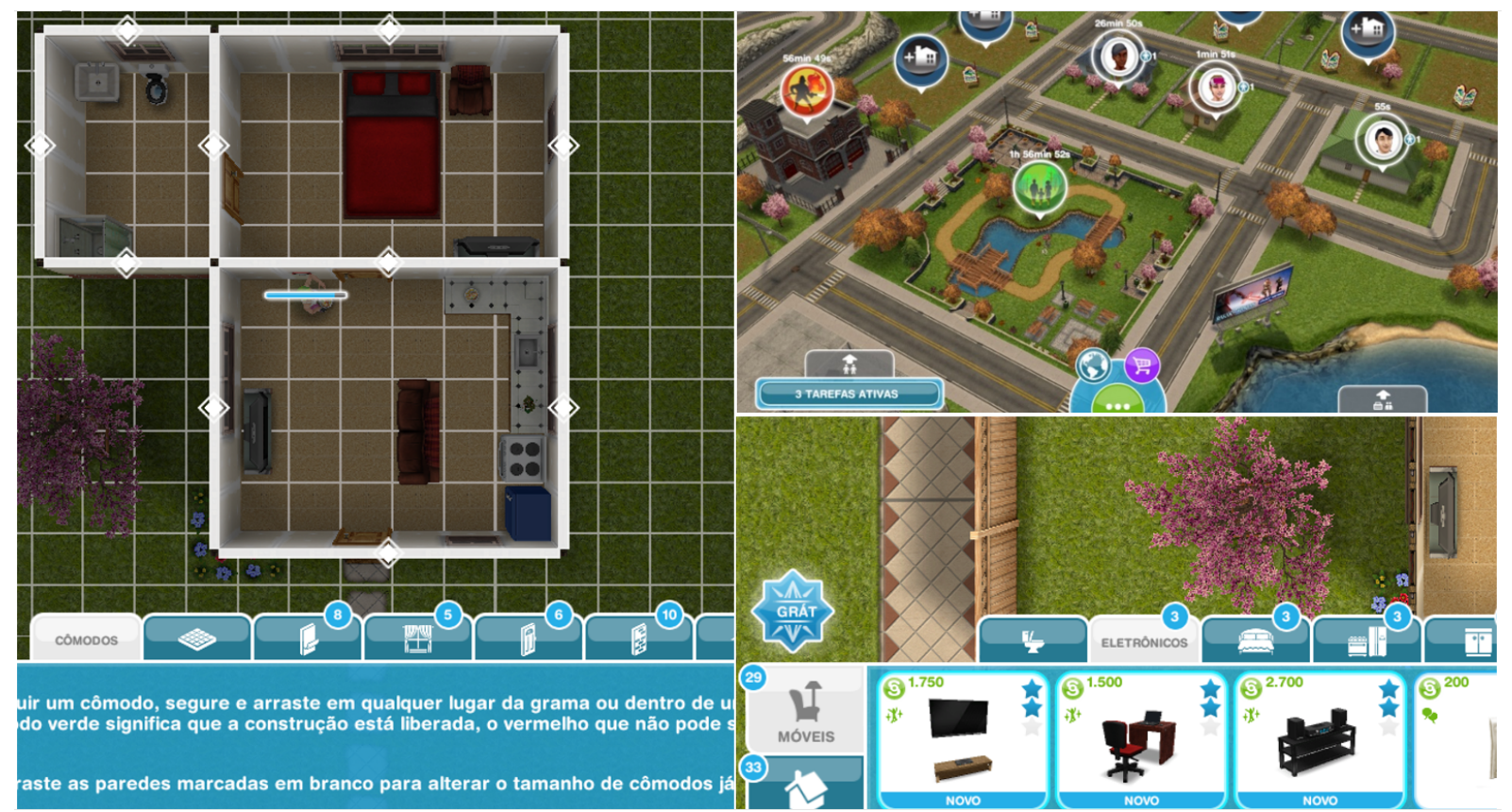

Figura 5.5: Barras de progresso de atividades

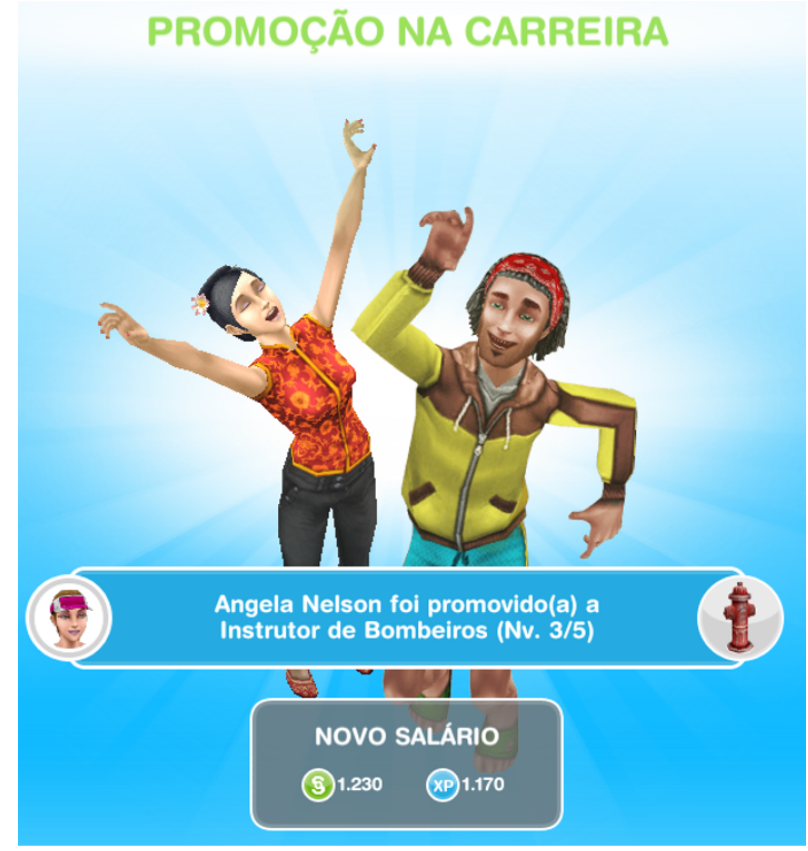

Figura 5.6: Promoção de um avatar

um painel contendo todos os avatares que vivem nesta cidade e as tarefas que estão sendo executadas com as respectivas barras de tempo e necessidades.

Alguns exemplos de exercícios que podem ser desenvolvidos com o tema deste jogo digital:

\section{Equação do primeiro grau (álgebra):}

(a) Se cada casa contém 10 pessoas, quantas casas eu preciso ter para que a população chegue a 1.000 pessoas?

(b) Em cada jornada de trabalho se ganha 1250 de simoleons (dinheiro do jogo) e demorase 9 horas. Uma TV, no jogo, pode ser comprada depois de exatamente 4 jornadas de 
trabalho. Quanto custa uma TV?

\section{Divisão (aritmética):}

(a) Se um cidadão do jogo (Sim) ganha 1250 a cada 9 horas de trabalho, quanto ele ganha por hora?

(b) Se eu tenho 12.000 de simoleons e cada estante da cozinha custa 4.000, quantas estantes eu posso comprar com esse dinheiro?

\section{Regra de 3 (aritmética e álgebra):}

(a) Se um Sim ganha 6.000 de salário em dois dias de trabalho, quanto terá acumulado em 5 dias?

\section{Calculo de área:}

(a) A casa do Sim Anastácia tem uma sala de 4 metros de largura por 6 de comprimento, um quarto de 4 metros de largura por 4 de comprimento, um banheiro de 2 metros de largura por 3 de comprimento e uma cozinha de 3 metros de largura por 5 de comprimento. Qual a área total da casa de Anastácia?

\section{Função polinomial de duas variáveis:}

(a) Supondo que todos os Sims de sua cidade ganham 1.000 por dia trabalhado, temos uma função linear de ganho definida por ' $\mathrm{f}(\mathrm{x}, \mathrm{y})=1000 \mathrm{x}^{*} \mathrm{y}$ ', onde ' $\mathrm{x}$ ' é o número de Sims, 'y' é o número de dias trabalhados e o resultado da função é o ganho total. Quanto a cidade coletará com os seguintes números de Sims, em 3 dias de trabalho: a) 5; b) 10; c) 3.?

\section{Função linear:}

(a) Supondo que todos os Sims de sua cidade ganham 1.000 por dia trabalhado, temos uma função linear de ganho definida por ' $f(x, y)=1000 x$ ', onde ' $x$ ' é o número de Sims e o resultado da função é o ganho total em um dia. Quanto a cidade coletará com os seguintes números de Sims: a) 5; b) 10; c) 3? Qual o gráfico formado por esta função?

\section{Clash of Clans}

O Clash of Clans é outro jogo digital utilizado nesta pesquisa para ensinar Matemática, ilustrado na Figura 5.7. Em uma experiência de aplicação do jogo digital, foi perguntado o que era porcentagem. Os alunos afirmaram que não sabiam ou deram uma explicação incompleta e superficial, pois admitiram não saber muito. Depois o pesquisador solicitou explicações gerais do jogo aos alunos. Um dos elementos do HUD, que era uma porcentagem (Figura 5.7), os alunos explicaram com suas palavras. O pesquisador então fez uma breve explanação, informando que aquilo que os alunos haviam explicado era porcentagem. Dessa forma, foi estabelecida uma ponte do significado ao conteúdo. Neste caso, as barras de recursos representam o máximo que os depósitos aceitam de recursos Figura 5.7, seu total, indiretamente, em forma de gráfico, ou, diretamente, na porcentagem de prédios destruídos em cada batalha, como mostra a Figura 5.7.

O jogo necessita de construção de unidades de tropas como parte de seus objetivos, porém existe um limite físico nos acampamentos, como mostra a Figura 5.7, com um acampamento totalmente 


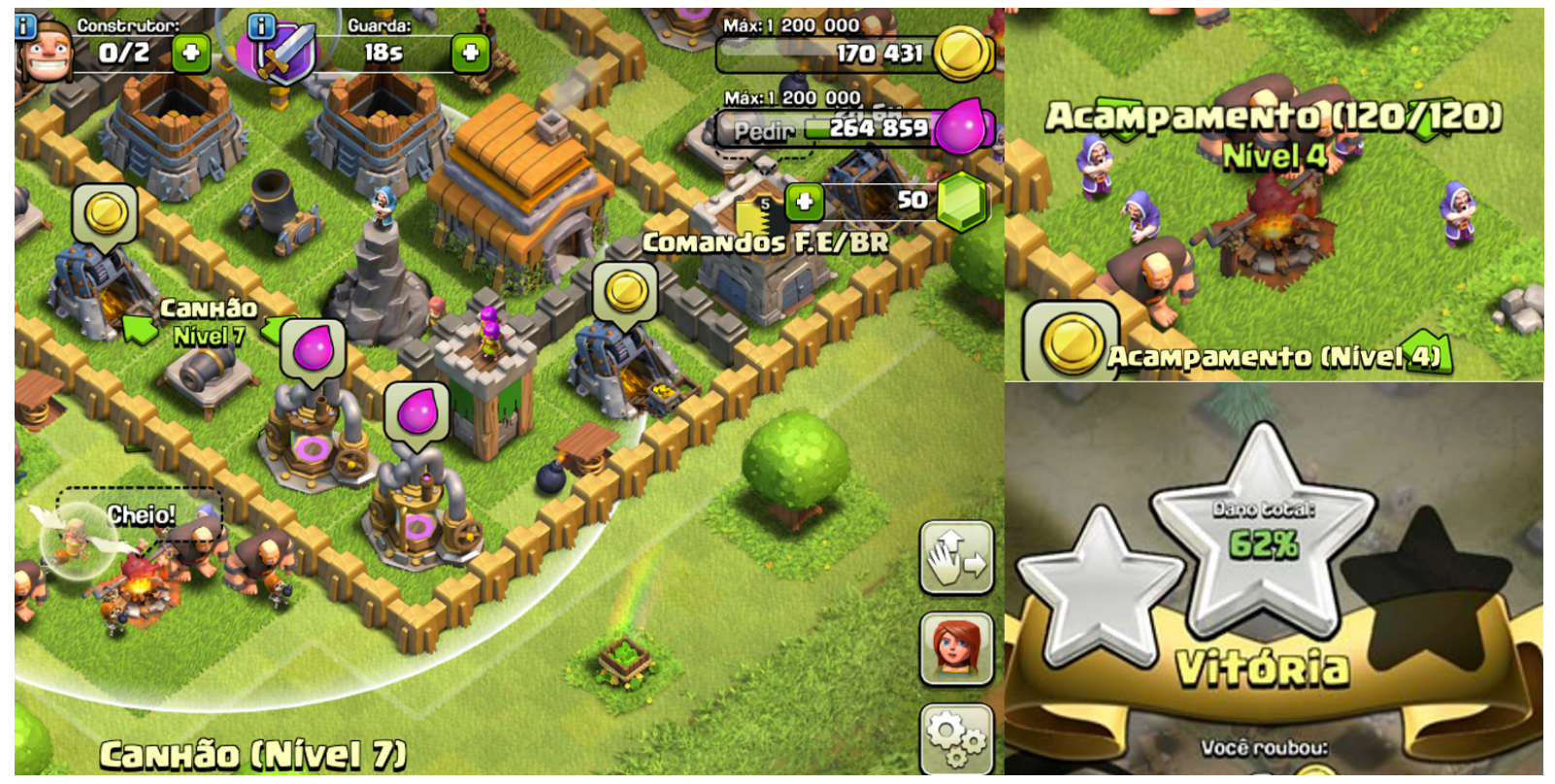

Figura 5.7: Imagens do jogo Clash of clans

preenchido. O jogador tem que associar o custo de recursos das unidades à capacidade do acampamento. Cada tropa possui vantagens e desvantagens, uma tropa com mais poderes ocupa mais de uma unidade no acampamento, por exemplo, a Valquíria, ilustrada na Figura 5.8, é mais forte que o gigante, ilustrado na Figura 5.8, porém ocupa mais espaço e recursos para sua construção. Dessa forma, o jogador tem que ponderar, num pensamento crítico, uma estratégia de atuação para melhorar sua performance nas suas batalhas. O entendimento matemático para tal é fundamental, ocorre indireta e intuitivamente. Toda essa riqueza de conteúdo pode ser trabalhada em sala de aula.

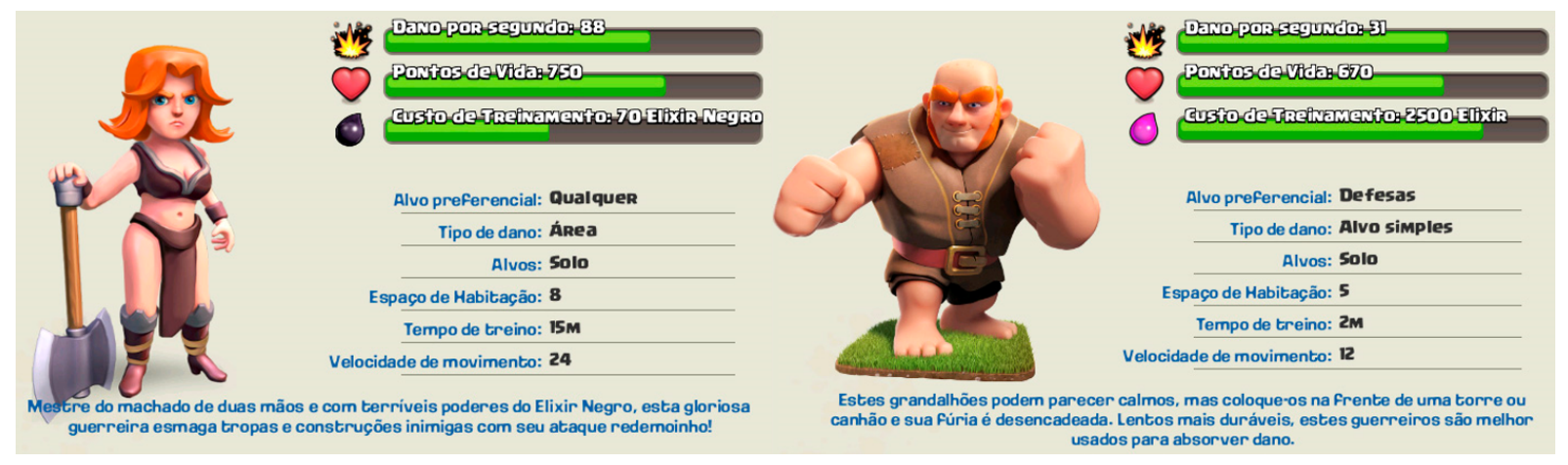

Figura 5.8: Valquíria e Gigante

Dessa forma, indiretamente ou intuitivamente, acontece uma regra de 3. Uma ponte também foi feita com essas explicações vindas dos próprios estudantes. Então o pesquisador fez, no quadro, exercícios práticos com linguagem do jogo digital. Os alunos resolveram o problema de maneira satisfatória e com muito entusiasmo.

Pôde-se observar que o jogo está repleto de gráficos em forma de barras, entre outros. Muitos dados matemáticos e estatísticos são utilizados para fornecer ao jogador informação suficiente para que possa montar sua vila adequadamente, bem como suas tropas para as batalhas. Além disso, existem relatórios de ataques e defesas que são lidos e interpretados pelo jogador, de acordo com o 
que aconteceu, e podem ser visto nos replays destes acontecimentos. O jogo também contém uma série de grandezas e medidas próprias, como tempo, espaço de habitação, dano por segundo, pontos de vida, quantidade de elixir, gold e assim por diante.

No caso deste jogo, temos o cálculo de área circular. Cada construção de defesa possui uma área circular de alcance de seus projéteis, conforme observa-se na Figura 5.7. O jogador então tem que usar sua noção de espaço e distribuir tais construções de forma a maximizar o poder de defesa.

O jogo também possui construções visando as defesas e a coleta de recursos. Uma série de operações matemáticas podem ser trabalhadas com estes dados, seja a quantidade de recursos coletados por hora, a capacidade de armazenamento, o custo da evolução de cada estrutura e o quanto isso vai aumentar a coleta de recursos, quanto tempo levará para que uma construção melhorada cubra seus custos e assim por diante. Abaixo serão descritos alguns problemas matemáticos que podem ser trabalhados.

\section{Equação do primeiro grau (álgebra):}

(a) Se eu possuia 5.000 de elixir e após produzir 2 gigantes eu passei a ter 2.500 de elixir, quanto custa cada gigante?

(b) Um gigante demora 2 minutos para ficar pronto. Uma Valquíria demora 7 vezes mais para ficar pronta. Quanto tempo demora para eu criar 3 Valquírias e 10 gigantes? Qual o tempo de treinamento de 1 Valquíria?

\section{Divisão (aritmética):}

(a) Se a cidade coleta 5.387 de gold a cada 24 horas, quanto a cidade coleta por hora?

(b) Se eu tenho 12.000 de gold e cada muro custa 4.000, quantos muros eu posso construir com esse dinheiro?

\section{Regra de 3 (aritmética e álgebra):}

(a) Se a cada 2 horas são coletados 500 de elixir, quanto tempo eu preciso para ter acumulado 3.000 de elixir?

\section{Calculo de área:}

(a) Suponha que sua aldeia contém 3 torres com alcance circular. Sendo uma torre de raio igual a 10 metros e as outras duas torres com raio de 12 metros, qual a área total de proteção das 3 torres?

\section{Função polinomial de duas variáveis:}

(a) Supondo que temos na nossa aldeia minas de ouro nível 5, que coletam 500 de gold por hora, e minas de ouro nível 4, que coletam 300 de gold por hora, temos então uma função linear de ganho de ouro definida por ' $\mathrm{f}(\mathrm{x}, \mathrm{y})=500 \mathrm{x}+300 \mathrm{y}$ ', onde ' $\mathrm{x}$ ' é o número de minas de nível 5, 'y' é o número de minas de nível 4 e o resultado da função é o ganho total por hora, quanto a cidade coletará com os seguintes números de minas: a) $\mathrm{f}(4,4)$; b) f(3,2); c) $\mathrm{f}(5,1)$ ? 
Após ilustrar exemplos de como aplicar elementos do HUD em conjunto com o funcionamento do jogo digital em questão, fica aclarado que as possibilidades são muitas e pode-se estender a outros jogos digitais que possuam uma lógica de funcionamento semelhante as que foram tratadas como uso de caso acima.

\subsection{Moodle com os professores}

Na décima segunda entrada do diário de campo, ocorrida no dia 21 de março de 2016, as professoras foram orientadas a registrar suas impressões, críticas, dúvidas e sugestões no Moodle, criado para a escola FN, pois as mesmas, bem como a coordenadora, haviam comunicado dificuldades para a utilização de tal ferramenta (Apêndice H).

Após isso, foi solicitado que a coordenadora entrasse no Moodle e respondesse as questões da pesquisadora Stela, líder do grupo Alpha. Após auxiliar a professora, que teve dificuldades para acessar o Moodle, foi discutido um pouco da experiência do uso de jogos e o interesse no projeto, a motivação dos alunos, além do fato de que a professora Roseli tinha gostado das atividades e resultados relacionados a jogos digitais em Matemática. Após a atividade, o pesquisador foi novamente falar com a coordenadora, Ana Tostes, para se despedir e a mesma comentou que uma das alunas teve que mudar de turma e relatou ter melhorado seu desempenho em matemática, e que queria continuar participando das atividades com jogos digitais, mesmo estando em outra turma.

Os professores relataram, nos grupos focais e entrevistas informais, dificuldades de acesso ao Moodle e redes sociais para acompanhar o projeto. Das dificuldades, a mais crítica foi relacionada à falta de recursos financeiros para adquirir internet, ou seja, só possuíam internet limitada nos smartphones, não possuíam internet fixa nem computadores em casa para acessar o Moodle. Sendo possível acessar somente quando estavam na escola. Porém, quando estavam na escola, estavam ocupados com a docência ou as atividades administrativas. Eventualmente, quando tentavam acessar o sistema do Moodle, não lembravam de suas credenciais de acesso. Mesmo com suporte do pesquisador e do grupo Alpha, os professores se queixavam de dificuldades constantes para acessar o Moodle.

\subsection{Análise dos resultados da mediação}

Conforme foi detectado pela pesquisa, seja nas conversas informais com os alunos, ao longo das visitas à escola, seja nas entrevistas individuais ou em grupos focais, ou mesmo nos formulários eventualmente submetidos pelos pesquisadores do grupo Alpha, que participam em diversas pesquisas na escola, os jogos digitais para dispositivos móveis, consoles e computadores são presentes na vida dos alunos muito mais do que eles mesmos podem perceber. Um fato recorrente que pode ajudar a elucidar essa afirmação é que as garotas inicialmente afirmaram não gostar de jogos digitais, não querer participar, porém, depois que um vínculo sócioemocional começou a se estabelecer com o pesquisador mediador, elas ficaram mais à vontade para falar seus receios, anseios, gostos e desgostos. Dessa forma, começaram a demonstrar interesse por jogos digitais, só que por alguns tipos que inicialmente não são considerados jogos digitais, pelas mesmas, por exemplo, Candy Crush e The Sims. No segundo ciclo da pesquisa-ação, as garotas gritaram, literalmente, que gostavam e queriam jogar o The Sims, logo após as mesmas afirmarem não gostar de jogos digitais. 
Quanto aos garotos, não foi difícil perceber o largo e profundo interesse no mundo dos jogos digitais, chegando até à façanha de utilizarem jogos complexos e proibidos para menores de 18 anos. Jogando em rede, com auxílio de redes sociais e comunicação online multiusuário, como conferência de chamadas por voz pelo Skype ${ }^{1}$, tudo isso para melhorar a performance durante o gameplay. Alguns aprenderam a utilizar e configurar servidores online alternativos para poderem jogar jogos em rede, como Minecraft ${ }^{2}$, com seus amigos, pois não tinham dinheiro para jogar nos servidores originais. Ou, até mesmo, se utilizam de programas complexos, como Hamachi ${ }^{3}$,para viabilizar uma conexão alternativa. Para manusear os programas de computadores citados, bem como para a configuração de servidores online, demanda-se habilidades cognitivas relacionadas a assuntos complexos, que podem ser considerados difíceis até para alunos de graduação. O aluno, que dialogou sobre sua experiência de uso de servidores online e outras alternativas de uso de tecnologias para jogar, pertencia à turma com mais baixos índices nas diversas avaliações aplicadas pela escola, tendo dificuldades básicas como soma e subtração. Tal aluno estava se preparando para uma prova de recuperação em Matemática quando teve o diálogo com o pesquisador. A turma deste mesmo aluno foi caracterizada pela escola e professores, entre outras coisas, como alunos ditos como deficientes, ou com problemas sérios de aprendizagem.

Ao longo da pesquisa, pouco a pouco, foi percebido o interesse geral por jogos digitais por parte dos alunos da escola e, conforme os boatos das experiências envolvendo jogos digitais foram sendo difundidos, a participação nas experiências envolvendo jogos digitais iam chegando aos ouvidos do pesquisador pelos próprios alunos e pelos professores da escola.

O autor Feuerstein et al. (2014) afirma que não basta a interação com objetos, é preciso criar interações entre homens com mediações prenhes de significados históricos, marcados pela produção de significados em movimento, portanto, por um processo de ressignificação constante. O mediador fez a ponte da percepção sensório-motor com definições e exemplos da significação dos jogos digitais com a cultura que o jogo digital compartilha um determinado significado ou sentido.

O mediador trabalhou com um leque de significações, trabalhadas em momentos diferentes de acordo com os exemplos explorados, colocando para o aluno problemas, contradições e saídas para tal, de forma que a criança tente buscar uma solução com sua interação sensório-motor e a modificação dos significados construídos anteriormente. Um aspecto importante da modificabilidade, ou "aprender a aprender", é o fato de ser um conceito que implica em possibilidade de modificar-se sempre, independente da habilidade ou das limitações.

O jogador é livre e à vontade para explorar suas escolhas, criações e ações, porém existe um limite de tempo que motiva o pensamento rápido e organizado para tomar a melhor resposta em tempo hábil. No jogo, a construção de significado é evidente e produtiva, além do desejo e da necessidade de compartilhar tais descobertas, ou mesmo para confirmar o significado encontrado. Podemos ver isso nas conversas entre alunos e mediador para compartilhar seus feitos ou para confirmar com o aluno se foi sua melhor decisão a forma de resolver determinado problema do jogo. Extrapolando o experimento, podemos constatar na bibliografia o estudo dos fóruns virtuais de compartilhamento de informação e criação dentro dos jogos digitais.

\footnotetext{
${ }^{1}$ Skype é um software que possibilita comunicações de voz e vídeo via internet, permitindo a chamada gratuita entre usuários em qualquer parte do mundo.

${ }^{2}$ Minecraft é um jogo digital que permite a construção usando blocos.

${ }^{3}$ O LogMeIn Hamachi é um programa de computador que simula uma rede local, ou Local Area Network (LAN), permitindo que pessoas à distância tenham acesso ao computador ou computadores alheios, principalmente para jogos, como se estivessem realmente ligados em LAN.
} 
O mundo dos jogos digitais possui termos da linguagem e contextualizações próprias, que passam a ser adotados pelos alunos em dado momento. Mediador e alunos passam a usar tais termos, além das experiências compartilhadas do jogo, para fortalecer significados em resultados positivos de determinada ação ou o conjunto delas, ou ainda para modificar um significado possivelmente errado, fruto de experiências que resultaram em insucesso. Os alunos usaram de sua cultura, conhecimento prévio e experiências passadas para melhor tentar resolver situações desconhecidas no jogo. O jogo não pune de forma intimidadora e possibilita novas tentativas de solucionar problemas sem desestimular o jogador.

As experiências de aprendizagem mediada permitiram a construção de instrumentos cognitivos ou conceituais de adaptação. No entanto, não basta ao educando expor-se a um ambiente rico em termos conceituais, pois isso não garante a apropriação nem dos conceitos nem dos instrumentos ou dos processos cognitivos envolvidos em sua produção, até porque a realidade é contraditória e nem sempre se mostra de forma direta.

Isso se torna evidente no ensino de Matemática da escola em questão, onde o professor dialoga com dificuldade, utilizando-se de conceitos e palavras fora da realidade sociocultural do aluno. Dessa forma o aluno não consegue solucionar os exercícios expostos em sala de aula e não consegue raciocinar criticamente ou associar analiticamente certos conceitos para tentar solucionar um dado problema.

Em sala de aula, notou-se que, além das dificuldades da falta de recursos de infraestrutura da escola, existe uma evidente falta de motivação do aluno em estar na classe, ou de motivação em aprender. Nesse sentido, os jogos permitiram que o aluno aprendesse através de uma disposição voluntária, criando relações não evidentes baseadas no seu conhecimento prévio e bagagem cultural, no ato de resolver problemas do jogo e de como lidar com as incertezas, pois a natureza dos jogos consiste em ambientes com mutação constante. Dessa forma, a experiência com jogos digitais gerou uma inclusão escolar evidente, repleta de emoções, onde existe uma integração sociocultural entre alunos e professores, que chega a causar euforia e ansiedade pelo prazer de dialogar sobre as experiências vividas com os jogos digitais. 


\section{Capítulo 6}

\section{Considerações Finais}

A motivação inicial para realização desta pesquisa foi o cenário educacional que anseia por mudanças mais relacionadas aos avanços das tecnologias e consequentes mudanças nos paradigmas de ensino e de aprendizagem. O interesse por este fato foi despertado durante a trajetória vivenciada no mestrado com tema relacionados aos jogos educativos e pela prática profissional com desenvolvimento de jogos digitais na instituição Centro Universitário Senac Santo Amaro - SP. Especificamente em relação aos jogos digitais a pesquisa das referências de estudos sobre o tema revelou diferenças importantes entre o Brasil e demais países estudados, comprovado por questões de política educacional, precariedade de estrutura da escola e formação docente.

Tal constatação pode ser analisada pela imersão num contexto escolar de Ensino Fundamental II em escola pública de tempo integral. Mesmo em uma escola onde anualmente quase todos os professores são trocados, rotatividade frequente motivada por política educacional de descaso, foi possível acreditar na possibilidade de inclusão escolar e de desenvolvimento de aprendizagem significativa por meio da mediação de jogos digitais, na construção de conhecimentos matemáticos previstos pela legislação educacional. Esta tese mostrou que o aluno pode ser protagonista de seu próprio desenvolvimento cognitivo e pessoal, desde que os mediadores, no caso o professor e a gestão da escola, sejam capazes de proporcionar um ambiente adequado. Mostrou também que os jogos digitais têm como impacto a geração de condições que beneficiam a fundação da experiência de aprendizagem. Ficou evidente o potencial dos jogos digitais para a formação do aluno. Os jogos digitais comprovaram, também, ser apoio auxiliar aos professores na superação da desmotivação dos alunos para o desenvolvimento de competências fundamentais presentes nos conteúdos curriculares.

A pesquisa no contexto escolar realizada durante dois anos, quase que de forma etnográfica, resultou na adoção de abordagem de natureza qualitativa como uma pesquisa-acão, suscitada pelas demandas encontradas (inexistência de formação permanente de professores, inexistência de cultura digital, infraestrutura precária e necessidade de práticas pedagógicas mais contextualizadas com tecnologias).

O uso de jogos digitais em uma perspectiva de superação dos desafios encontrados e citados, surgiu como transformação de práticas tradicionais de ensino de Matemática assim como de mudanças profundas na concepção de avaliação da aprendizagem. O excesso de formalismo, questões burocráticas administrativas, rotatividade docente e exclusão escolar, incompatíveis com uma educação de qualidade, acabaram gerando por meio desta investigação elementos relevantes que necessitam ser repensados por todos aqueles que defendem qualidade diferente para escolaridade básica.

Diante do exposto ao discutir a inserção dos jogos digitais no componente curricular da Mate- 
mática, essa investigação optou por voltar a atenção para a redução das dificuldades encontradas. É neste ponto que as atividades de pesquisa emergiram com destaque a grande oportunidade de se construir conhecimento sobre a relevância que os jogos digitais podem trazer a às questões curriculares do ensino da Matemática.

Outro elemento fundamental para a compreensão e argumentação fundamentadas no diálogo das ideias de Feuerstein contidas nas teorias desenvolvidas por ele e inspiradas em Piaget e Vygotsky, concentra-se na motivação de revelar as contribuições dos jogos digitais para o desenvolvimento das aprendizagens dos alunos.

Especialmente no Ensino Fundamental II a composição curricular é fragmentada, tornando a Matemática concentradora de problemas vivenciados pela educação básica no Brasil que parece representar um dos principais fatores que geram desinteresse dos alunos pela escola. O currículo é composto de uma quantidade excessiva de disciplinas, pouco articuladas entre si, cujos programas voltam-se para suas próprias questões, conferindo desintegração com os demais campos de conhecimento.

Essa investigação constatou que muitas conexões entre as diferentes áreas de conhecimento escolar, tem apoio no ensino da Matemática por meio de jogos digitais. Os jogos SimCity BuildIt e Clash of Clans, escolhidos pelos alunos reforçaram as ações que podem reduzir a fragmentação curricular. Os alunos conseguiram estabelecer conexões dos conteúdos matemáticos, de maneira transversal, em problemas reais da comunidade em que vivem. Da especificidade da Matemática, houveram extensões para a compreensão do raciocínio lógico e de seus complexos registros notacionais, normalmente expostos pela cultura escolar, assim como, a resolução de problemas incentivados pela flexibilidade e autonomia dos jogos digitais, alcançaram parâmetros jamais planejados na educação escolar. Os alunos estabeleceram relações com a possibilidade de mapear seus pensamentos, resoluções de problemas, descrição e registro dos mesmos e diferentes outras áreas de conhecimento como Língua Portuguesa, História, Ciências, Política, Economia, Saúde como ilustrados no Capítulo 5 desta investigação.

Os jogos digitais desempenharam um papel relevante no desenvolvimento de competências maiores totalmente alinhadas com o espírito dos Parâmetros Curriculares Nacionais (PCN), nem sempre contemplados nos planejamentos dos professores da escola.

É importante destacar que confluência de mídias, naturalmente suscitadas durante a pesquisa, como um ambiente virtual Moodle para favorecer o diálogo entre professores; o uso de redes sociais WhatsApp e FaceBook, potencializaram a construção de conhecimentos observada durante esses anos.

Ficou claro que torna-se cada vez mais urgente refletir permanentemente sobre a amplitude das tecnologias como suporte prático para apoiar os conteúdos tradicionalmente estudados, mas agora, sob perspectivas de mobile learning (uso de celulares dos alunos e professores) e BYOD (traga seu próprio dispositivo). Tais elementos favorecem a sustentabilidade educacional que deve ser pensada por toda equipe escolar e pesquisas, no sentido de reduzir graves problemas já apontados na caracterização dos sujeitos e contexto escolar. Ao longo deste trabalho ressaltamos as demandas registradas e descritas, há décadas vem sendo denunciadas pela produção acadêmica.

Nesse sentido, ressaltamos o caráter integrador das tecnologias tanto para o resgate da relevância da matemática na construção de conhecimentos, quanto para a importância de construção de pensamento científicos mais aproximado do que acontece no interior da escola básica. 
Levando em conta as características dos jogos digitais (flexibilidade, motivação, atenção concentrada, autonomia na resolução de problemas, sentimentos de pertencimento, transcendência da aprendizagem, entre outros) foi possível desvelar que existem possibilidades de fortalecimento de uma aprendizagem mais significativa e sob perspectivas de abordagem interdisciplinares. A partir dessa identificação foram desenvolvidas estratégias metodológicas adequadas para o ensino da matemática, com maior sentido e significado para os alunos.

Não se pretendeu nesta pesquisa apresentar estratégias que possam ser consideradas como modelo de como ensinar matemática. Antes, objetivou explicar os desafios encontrados no contexto escolar e como podem ser resolvidos, com o apoio das tecnologias e com a reiterada necessidade de formação permanente de professores, que merece espaço de maior consideração no cotidiano das escolas brasileiras.

Uma metodologia de interação entre jogos e conteúdos curriculares requer o planejamento de roteiro das atividades, delineamento das habilidades a serem desenvolvidas, critérios diferenciados de avaliação de cada estudante e incentivo às atividades colaborativas, onde seja possível contar com as vozes dos alunos. Os resultados alcançados contaram com a autoavaliação dos alunos, o que reforçou o entendimento e a compreensão das relações matemáticas, com maior sentido e significado.

A reflexão feita até aqui nas considerações finais, motivada pela crença de que os jogos digitais podem apoiar aprendizagens mais significativas, converge para o reconhecimento da urgência em valorizar ideias transformadoras para a área do currículo da Matemática na escola básica. No entanto não nos detivemos numa forma mais sistematizada de fazer isso, usar os jogos digitais cujas contribuições foram reveladas pela pesquisa.

Assim ao longo da investigação foram sendo construídos argumentos de que as ideias fundamentais sobre a aprendizagem significativa e mudanças estruturais do raciocínio lógico-matemático devem ser desenvolvidas ao longo da escolaridade de todos os alunos brasileiros, no estudo dos diferentes conteúdos contemplados tradicionalmente pela educação brasileira.

O professor precisaria de um salário digno e uma formação continuada garantida pelo governo. A escola precisaria conter espaços livres e libertadores, onde os professores possam inovar em formas de ensinar e avaliar, como o uso de jogos digitais. O pensamento crítico do aluno, usado em seu cotidiano, bem como nas experiências com jogos digitais, precisaria ser aproveitado em sala de aula.

Os jogos digitais são exemplos de onde há naturalmente uma transmissão cultural. O uso das experiências passadas do jogador é evidente. O jogo digital está inserido em um mundo de rápidas mudanças, dentro dos avanços tecnológicos e da nova cultura cibernética. O jogo sacia os anseios e as necessidades do aluno por diversão e aprendizado, pois estes aprendem em meio à diversão. $\mathrm{O}$ jogo faz parte da nova cultura das novas relações sociais online.

Ficou claro que, para habilitar ou desejar a modificação da situação educacional, urge projetar recursos estratégicos que alimentem um ambiente de suporte que possa confirmar a modificabilidade demonstrada com o uso de jogos digitais e reconhecidas por meio das intervenções aqui relatadas.

A contribuição desta tese traz luz às possibilidades de melhorias para a escola brasileira. O uso de jogos digitais com intencionalidade pedagógica é uma possibilidade real de melhoria educacional, que está alinhada aos anseios e necessidades dos alunos e da escola como um todo. O uso de jogos digitais se mostrou uma poderosa forma de inclusão escolar. Os alunos demonstraram contentamento, engajamento e felicidade nas atividades libertadoras do uso de jogos digitais.

Outra contribuição importante foi a provocação feita aos professores e à equipe gestora, que teve 
que adaptar a escola para receber as experiências com jogos digitais. Mobilizou a gestão da escola que, apesar das restrições e dificuldades financeiras, adquiriu materiais como WiFi e Datashow, para que o grupo Alpha de pesquisa da FE-USP, do qual o autor desta tese é membro, desempenhasse as vicissitudes de pesquisa imersas em contextos reais de aprendizagem.

A presença das tecnologias de informação e de comunicação, como os jogos digitais e as redes sociais utilizadas nesta investigação, contribuíram na direção de novas formas de aprender, assim como sugerem novas formas para ensinar. Espera-se que os resultados desta tese possam continuar apoiando o uso de jogos digitais como alternativas libertadoras e revolucionárias não só para o engajamento educacional, mas como formas de construção de conhecimento, de avaliação e inclusão escolar. Diante do exposto, espera-se que os resultados desta investigação possam apoiar e inspirar a concepção de políticas educacionais mais contextualizadas e alinhadas com os recursos tecnológicos crescentes. 
Apêndices 


\section{Apêndice A}

\section{Termo de Consentimento Livre e Esclarecido}

Você está sendo convidado(a) para participar, como voluntário, em uma pesquisa. Após ser esclarecido(a) sobre as informações a seguir, no caso de aceitar fazer parte do estudo, assine ao final deste documento, que está em duas vias. Uma delas é sua e a outra é do pesquisador responsável.

Desde logo fica garantido o sigilo das informações. Em caso de recusa você não será penalizado(a) de forma alguma.

\section{INFORMAÇÕES SOBRE A PESQUISA}

Título do Projeto: Uso de Games para o ensino de matemática

Objetivo da pesquisa: Investigar os efeitos da interatividade dos games na performance do entendimento de álgebra, e outros conteúdos do currículo escolar.

Pesquisa vinculada ao Programa de Pós-graduação em Educação da Faculdade de Educação da Universidade de São Paulo, em nível de Doutorado, acerca do "tema mobile learning", a qual será desenvolvida sob a responsabilidade da pesquisadora Adalberto Bosco Castro Pereira, sob a orientação da Profa. Dra. Stela da C. B. Piconez, no (local) Escola Fernando Nobre, situada no município de Cotia.

Os sujeitos são convidados a participar da pesquisa como voluntário, tendo a liberdade para recusar-se ou retirar seu consentimento, em qualquer fase da pesquisa, sem penalidade alguma e sem prejuízo ao seu cuidado.

Não há nenhum gasto, ganho, ressarcimento, indenização financeira, risco, prejuízo ou desconforto que possam ser provocados aos sujeitos da pesquisa.

Oferecemos a garantia de esclarecimentos, antes e durante o curso da pesquisa, e, sobretudo garantimos o sigilo que assegura a privacidade dos sujeitos quanto aos dados confidenciais envolvidos na pesquisa.

A coleta de dados será realizada a partir das técnicas de entrevistas individuais e grupos focais.

O resultado do trabalho poderá contribuir para auxiliar futuros professores no uso de games para o ensino de matemática e outras disciplinas.

Para esclarecimentos com relação às dúvidas éticas do projeto, você poderá entrar em contato com o(a) pesquisador(a) no tema mobile learning por e-mail: bosco@ime.usp.br ou por telefone 
(inclusive ligações a cobrar): 11 94999-1207.

Adalberto Bosco Castro Pereira Pesquisador CONSENTIMENTO DA PARTICIPAÇÃO DOS ALUNOS

$\mathrm{Eu}$, $\mathrm{RG}$ , abaixo assinado, concordo em participar do estudo no tema mobile learning. Fui devidamente informado(a) e esclarecido(a) pelo(a) pesquisador(a) Adalberto Bosco Castro Pereira sobre a pesquisa, os procedimentos nela envolvidos, assim como os possíveis riscos e benefícios decorrentes de minha participação. Foi-me garantido o sigilo das informações e que posso retirar meu consentimento a qualquer momento, sem que isto leve à qualquer penalidade.

Local e data,

Assinatura do sujeito ou responsável: 
Apêndice B

Termo de Consentimento do Diretor da Escola Fernando Nobre 


\section{SECRETARIA DA EDUCAÇÃO DO ESTADO DE SÃO PAULO DIRETORIA DE ENSINO DA REGIÄO DE CARAPICUÍBA ESCOLA ESTADUAL FERNANDO NOBRE}

Cotia (SP), 02 de setembro de 2015.

Ao Comitê de Ética em pesquisa com Seres Humanos Faculdade de Educação da Universidade de São Paulo

\section{AUTORIZAÇÃO PARA REALIZAÇÃO DE PESQUISA}

Eu, José Teodoro Filho. Diretor geral da Escola Estadual Fernando Nobre, venho por meio desta informar a V. Sa. que autorizo o pesquisador Adalberto Bosco Castro Pereira, aluno de pós-graduação, em nível de doutorado, do Instituto de Matemática e Estatística da Universidade de São Paulo (IME-USP) em parceria com a Faculdade de Educação da Universidade de São Paulo (FEUSP), a realizar/desenvolver a pesquisa intitulada "Uso de Games para o ensino de matemática", sob orientação da profa. Dra. Stela da Conceição Bertholo Piconez.

Declaro conhecer e cumprir as Resoluções Éticas Brasileiras, em especial a Resolução do CNS $n^{\circ}$ 466/2012. Esta instituição está ciente de suas corresponsabilidades como instituição coparticipante do presente projeto de pesquisa e de seu compromisso no resguardo da segurança e bem-estar dos participantes de pesquisa nela recrutados, dispondo de Infraestrutura necessária e apto ao desenvolvimento da pesquisa e para atender eventuais problemas dela resultantes.

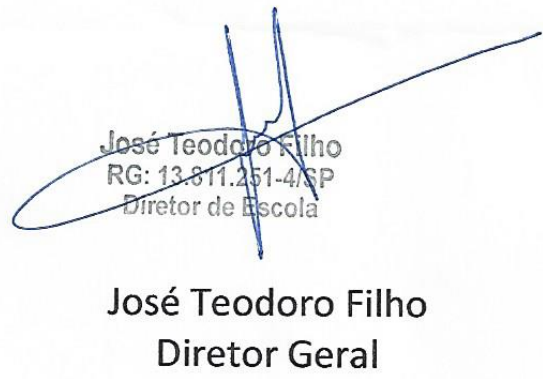


Apêndice C

Sondagem Diagnóstica - Alunos 


\section{ANEXO \\ Questionário Informativo - Tipos de Celulares}

Universidade de São Paulo/ Faculdade de Educação

Grupo Alpha de Pesquisa (CNPq) - Docente-responsável: Profa. Dra. Stela C Bertholo Piconez

Data ___ _ _ ___ Escola Estadual Fernando Nobre

Ano Escolar:

I - Pesquisa sobre tipos de celulares usados pelos alunos. Por favor, responda:

\begin{tabular}{l|c}
\hline Qual é a marca do seu celular? & \\
\hline Seu celular tira fotos? & $\square$ sim $\square$ não \\
\hline Grava e reproduz áudio? & $\square$ sim $\square$ não \\
\hline Grava e reproduz vídeos? & $\square$ sim $\square$ não \\
\hline Acessa a Internet? & $\square$ sim $\square$ não \\
Se sim, acessa via WiFi? $\square$ via 3G? &
\end{tabular}

Sabe qual é o sistema operacional dele? $\quad \square$ Android $\square$ iOS $\square$ Windows

Seu celular permite baixar jogos ou outros aplicativos? $\square$ sim $\quad \square$ não

II - Escreva três assuntos ou temas que você acha que poderia estudado em qualquer disciplina (colocar em ordem de preferência)

1.

2.

3.

III - Escreva três assuntos ou temas que você não gostaria de conhecer em qualquer disciplina. Explicar as razões (causas)

1.

2.

3. 
Apêndice D

Sondagem Diagnóstica Estudantes e uso das TDIC 


\section{ANEXO \\ Sondagem Diagnóstica Estudantes e Uso das TDIC}

UNIVERSIDADE DE SÃO PAULO/ FACULDADE DE EDUCAÇÃO/GRUPO ALPHA (CNPq) Escola Estadual Fernando Nobre

\section{A. Dados de Caracterização}

1. Sexo: Feminino ( ) Masculino ( ) Ano/Série:

2. Possui celular? ( ) sim não( ) Qual o tipo?

3. Possui computador e/ou tablet? ( ) sim não ( )

4. Possui internet em casa? ( ) sim ( ) não

5. Possui wi-fi em casa? ( ) sim ( ) não

6. Frequenta lanhouses no bairro? ( ) sim ( ) não

7. O que você mais acessa em seu celular?

8.. E no computador?

9. Quais as tecnologias digitais que vocês utilizam em suas aulas que mais gostam?
a)
b)
c)

10. Quais aplicativos, softwares ou recursos digitais você conhece que seriam interessantes para serem utilizados nas aulas de:

a) Matemática:

b) Português:

c) Inglês:

d) História:

e) Geografia:

f) Ciências:

g) Educação Física

h) Artes:

i) Projetos das Oficinas:

Figura D.1: Documento digitalizado 
Apêndice E

Uso De Jogos Digitais Na Oficina De Experiências Matemáticas 


\section{Questionário:}

Nome:

Série:

Horário das aulas:

Horário das oficinas:

Data de nascimento:

O que você possui em sua casa:

1. Possui computador em casa? Sim ( ), Não( ). Caso possua, quantos? , qual a Marca e Modelo?

2. Possui Tablet em casa? Sim ( ) , Não( ). Caso possua, quantos? Modelo?

3. Possui Celular em casa? Sim ( ), Não( ). Caso possua, quantos? qual a Marca e Modelo?

4. Possui videogame? em casa? Sim ( ), Não( ). Caso possua, quantos? , qual a Marca e Marca e Modelo:

Você gosta de games? Sim ( ), Não ( ). Se gosta, quais são seus favoritos?

1.

2.

3.

( ) Nenhum.

Caso goste de games, descreva em poucas palavras o que você sente quando joga, e por que você gosta de jogar:

Você acha que um exame de ordem seria importante para selecionar os profissionais que estão se formando?
( ) $\operatorname{Sim}$
( ) Não

5. Qual a sua visão sobre o mercado de trabalho?
( ) Está em baixa, mas a tendência é melhorar
( ) Está em baixa e a tendência é piorar
( ) Está em alta com tendência a melhorar
( ) Está em alta mas não por muito tempo

6. Como você pretende atuar após a sua formação?

( ) Trabalhando em uma empresa de pequeno porte, não dando tanta ênfase ao salário

( ) Trabalhando em uma empresa de grande porte, buscando subir de cargo 
( ) Trabalhando como autônomo, formando sociedade com os amigos

( ) Trabalhando com pesquisa em programas de pós graduação strictu sensu (mestrado e doutorado)

( ) Outros:

7. O Brasil possui estrutura para todos os futuros formandos em engenharia civil?

( ) Sim ( ) Não

\section{Questões sobre o curso:}

1. Você acha que a faculdade atende as exigências do mercado?
( ) Sim
( ) Não

Se não, por quê?

2. Qual sua opinião sobre o aproveitamento de apenas 30 horas de estágio não obrigatório nas horas complementares?

( ) Injusto ( ) Justo

3. Já pensou em desistir do curso?
( ) Sim
( ) Não

Se sim, por que?

4. O curso de engenharia civil atendeu suas expectativas?
( ) Totalmente
( ) Sim, mas pode melhorar
( ) Não atendeu

5. O que você acha (achou) do curso oferecido pela instituição?

( ) Ótimo, me possibilita a desenvolver todas as habilidades necessárias para atuar como um engenheiro

( ) Bom, me passa todo o conhecimento teórico mas não me capacita totalmente para atuar na prática

( ) Razoável, as matérias são as necessárias para a formação de um engenheiro porém a maioria dos professores não são didáticos

( ) Ruim, nem todas as matérias são essenciais para a formação de um engenheiro e os professores não incentivam os alunos com didática das aulas

( ) Péssimo, as matérias não condizem com a área de atuação de um engenheiro e os professores desmotivam os alunos 
Apêndice F

Questionário de Sondagem Diagnóstica dos Professores 


\section{Questionário de Sondagem Diagnóstica dos Professores (Anexo 5).}

Questão 1: Como poderíamos usar as Tecnologias Digitais de Informação e de Comunicação (TDIC) nesta escola?

\begin{tabular}{|c|c|c|}
\hline CATEGORIAS & \multicolumn{2}{|l|}{ RESPOSTAS } \\
\hline Infraestrutura & $\begin{array}{l}\text { Acessibilidade democrática para fins educacionais } \\
\text { Acesso de qualidade } \\
\text { Possibilidade de uso em todas as disciplinas } \\
\text { Possibilidade de uso da lousa digital }\end{array}$ & $\begin{array}{l}\operatorname{sim}(\text { ) não ( ) } \\
\operatorname{sim}(\text { ) não ( ) } \\
\operatorname{sim}(\text { ) não ( ) } \\
\operatorname{sim}(\text { ) não ( ) }\end{array}$ \\
\hline $\begin{array}{l}\text { Docência } \\
\text { (Didática) }\end{array}$ & $\begin{array}{l}\text { Ensinar os estudantes a pesquisar com TDIC } \\
\text { Uso de Jogos e vídeos educacionais } \\
\text { Criação de trabalhos diferenciados } \\
\text { Uso de comunicação interna via redes sociais } \\
\text { Uso de interatividade síncronas e assíncronas } \\
\text { Uso de grupos virtuais de aprendizagem } \\
\text { Uso da web em sala de aula para discussões } \\
\text { Interação com fatos do mundo todo } \\
\text { Uso de aplicativos como Facebook, Twitter } \\
\text { Whatsapp, Messenger, Skype etc. } \\
\text { Tirar dúvidas online com professores } \\
\text { Uso de videoconferência com professores } \\
\text { de outros estados e/ou países }\end{array}$ & $\begin{array}{l}\operatorname{sim}(\text { ) não ( ) } \\
\operatorname{sim}(\text { ) não ( ) } \\
\operatorname{sim}(\text { ) não ( ) } \\
\operatorname{sim}(\text { ) não ( ) } \\
\operatorname{sim}(\text { ) não ( ) } \\
\operatorname{sim}(\text { ) não ( ) } \\
\operatorname{sim}(\text { ) não ( ) } \\
\operatorname{sim}(\text { ) não ( ) } \\
\operatorname{sim}(\text { ) não ( ) } \\
\operatorname{sim}(\text { ) não ( ) } \\
\operatorname{sim}(\text { ) não ( ) }\end{array}$ \\
\hline Aprendizagem & $\begin{array}{l}\text { Uso de recursos de aprendizagem com tecnologia } \\
\text { Agregar valores em nível de conhecimento } \\
\text { e interesse dos estudantes } \\
\text { Melhorar aprendizagem dos estudantes }\end{array}$ & $\begin{array}{l}\text { s sim ( ) não ( ) } \\
\operatorname{sim}(\text { ) não ( ) } \\
\operatorname{sim}(\text { ) não ( ) }\end{array}$ \\
\hline Gestão & $\begin{array}{l}\text { Aprimorar a gestão e comunicação educacional } \\
\text { Aproximar escola-comunidade }\end{array}$ & $\begin{array}{l}\operatorname{sim}(\text { ) não ( ) } \\
\operatorname{sim}(\text { ( ) não ( ) }\end{array}$ \\
\hline
\end{tabular}

Questão 2: Quais as atividades com uso das Tecnologias Digitais de Informação e de Comunicação (TDIC) que seus alunos mais apreciam?

\begin{tabular}{|c|c|c|}
\hline Categorias & Respostas & \\
\hline Infraestrutura & $\begin{array}{l}\text { Uso do Pacote Office,Wikipedia, Google, Museus } \\
\text { Uso de Facebook, Whatsapp, Instagran, Twitter } \\
\text { ) } \\
\text { Sites de música } \\
\text { Jogos interativos, games etc. } \\
\text { Uso de celular liberado em sala de aula } \\
\text { ) Equipamentos apresentação de vídeos } \\
\text { ) }\end{array}$ & $\begin{array}{l}\operatorname{sim}(\text { ) não ( } \\
\operatorname{sim}(\text { ) não ( } \\
\operatorname{sim}(\text { ) não ( ) } \\
\operatorname{sim}(\text { ) não ( ) } \\
\operatorname{sim}(\text { ) não ( } \\
\operatorname{sim~(~)~não~(~}\end{array}$ \\
\hline $\begin{array}{l}\text { Docência } \\
\text { (Didática) }\end{array}$ & $\begin{array}{l}\text { Uso das redes sociais para escrever } \\
\text { em vários gêneros, música, poesia etc } \\
\text { Uso para pesquisa } \\
\text { Us } \\
\text { Uso para atividades lúdicas ou entretenimento } \\
\text { Criação de vídeos } \\
\text { Comunicação social via redes sociais }\end{array}$ & $\begin{array}{l}\operatorname{sim}() \text { não ( ) } \\
\operatorname{sim}(\text { ) não ( } \\
\operatorname{sim}() \text { não ( } \\
\operatorname{sim}(\text { ) não ( } \\
\operatorname{sim}(\text { ) não ( }\end{array}$ \\
\hline
\end{tabular}




\begin{tabular}{|c|c|c|}
\hline & $\begin{array}{l}\text { Uso de todas as TDIC } \\
\text { Uso em pesquisas, trabalhos escolares } \\
\text { Uso de músicas e imagens } \\
\text { ) } \\
\text { Uso de celulares para s tarefas pedagógicas } \\
\text { Uso de celulares para interação social } \\
\text { () }\end{array}$ & $\begin{array}{l}\operatorname{sim}(\text { ) não ( ) } \\
\operatorname{sim}(\text { ) não ( } \\
\operatorname{sim}(\text { ) não ( } \\
\operatorname{sim}(\text { ) não ( } \\
\operatorname{sim(~)~não~(~}\end{array}$ \\
\hline Aprendizagem & $\begin{array}{l}\text { Uso para melhorar e ampliar a aprendizagem } \\
\text { Uso para desenvolvimento de competências } \\
\text { Uso para avaliação (testes e provas) }\end{array}$ & $\begin{array}{l}\operatorname{sim}(\text { ) não ( ) } \\
\operatorname{sim}(\text { ) não ( } \\
\operatorname{sim}(\text { ) não ( ) }\end{array}$ \\
\hline Gestão & $\begin{array}{l}\text { Uso para recomendações aos estudantes } \\
\text { Uso para comunicação com professores } \\
\text { Uso para interação com a comunidade e família }\end{array}$ & $\begin{array}{l}\operatorname{sim}(\text { ) não ( ) } \\
\operatorname{sim}(\text { ) não ( ) } \\
\operatorname{sim}(\text { ) não ( ) }\end{array}$ \\
\hline
\end{tabular}

Questão 3: Se lhe fosse dada a oportunidade de modificar alguma coisa na escola em relação ao uso das TDIC, até três coisas, quais seriam elas?

\begin{tabular}{|c|c|c|}
\hline CATEGORIAS & DESAFIOS & \\
\hline Infra estrutura & $\begin{array}{l}\text { Atualização de softwares } \\
\text { Ter equipamentos que funcionem } \\
\text { Conexão via internet, wifi para todos funcionando sempre } \\
\text { Disponibilidade de tablets, celulares e mais computadores } \\
\text { para as atividades cotidianas na sala de aula } \\
\text { Organização de horários específicos para } \\
\text { uso das TDIC para cada sala } \\
\text { Presença de profissionais especializados } \\
\text { Para manutenção na sala de informática } \\
\text { Criação de uma sala na web (ambiente virtual de } \\
\text { aprendizagem, blog etc) } \\
\text { Melhor acesso e uso livre da internet e dos celulares } \\
\text { Ampliar tempo destinado ao uso das mídias }\end{array}$ & $\begin{array}{l}(\text { ) } \\
(\text { ) } \\
(\text { ) }\end{array}$ \\
\hline $\begin{array}{l}\text { Docência } \\
\text { (Didática) }\end{array}$ & $\begin{array}{l}\text { Formação e qualificação para os professores } \\
\text { Criar uma forma de comunicação apreciada pelos estudantes } \\
\text { Implementação de cursos para saber acessar } \\
\text { a web em todas as salas } \\
\text { Saber usar as TDIC adequadas a cada disciplina } \\
\text { Aprender a usar didaticamente as tecnologias } \\
\text { móveis (tablets e celulares) } \\
\text { Usar as redes sociais com intencionalidade pedagógica } \\
\text { Implementação de cursos de aperfeiçoamento } \\
\text { para professores sobre uso das TDIC } \\
\text { Usar teleconferências }\end{array}$ & $\begin{array}{l}(\text { ) } \\
()\end{array}$ \\
\hline Aprendizagem & $\begin{array}{l}\text { Aprender a aprender dando aulas com as tecnologias } \\
\text { Saber avaliar usando as tecnologias }\end{array}$ & \\
\hline Gestão & $\begin{array}{l}\text { Melhorar a comunicação de professores e corpo diretivo } \\
\text { Receber instruções oficiais pelo ambiente virtual }\end{array}$ & \\
\hline
\end{tabular}


Apêndice G

Moodle 


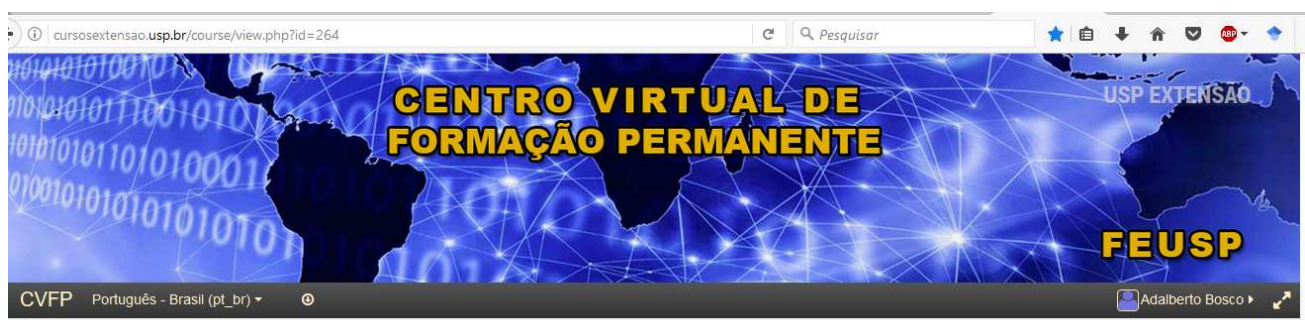

Página inicial > Centro Virtual de Formação Permanente > CVFP

\section{ADMINISTRAÇ̄̃o}

- Administração do curso

AMBIENTAÇÃo

B Bem Vindos ao Centro Virtual de Formação Permanente

Bem Vindos ao Centro Vi

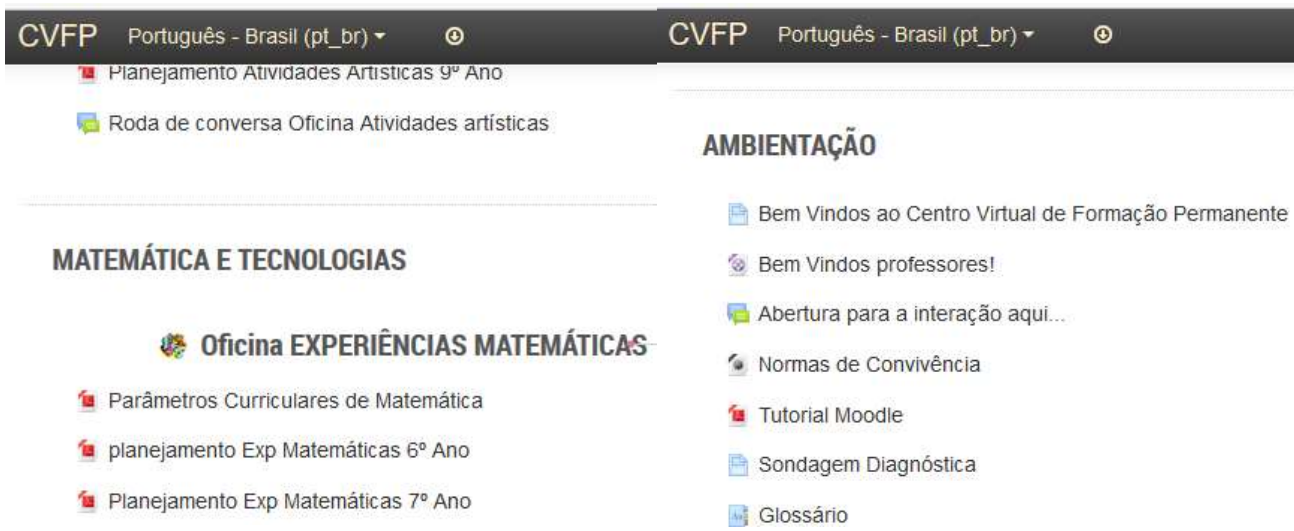


Apêndice H

Moodle-Forum 
CVFP » Fóruns » FÓRUM OFICINAS EXPERIÊNCIAS MATEMÁTICAS"-2016 » FÓRUM SOBRE AS OFICINAS ËXPERIÊNCIAS MATEMÁTICA"-2016

Imagem

de

Adalberto Re: FÓRUM SOBRE AS OFICINAS ËXPERIÊNCIAS MATEMÁTICA"-2016

Bosco por Adalberto Bosco Castro Pereira - quarta, 16 Mar 2016, 19:59

Castro

Olá, muito interessante professora Stela, nessa segunda feira, dia 21/01 eu irei na escola ajustar 0 WiFi e colocar a senha nos dispositivos dos alunos que estão participando do projeto para que possam jogar. Caso tenham alguma dificuldade para acessar o Moodle, estou a disposição para tirar dúvidas

Márcia Aparecida Lara <marcialara_ap@hotmail.com>

31 de março de 2016 20:50

Para: Adalberto Bosco Castro Pereira <bosco@ime.usp.br>

CVFP » Fóruns " FÓRUM OFICINAS EXPERIÊNCIAS MATEMÁTICAS"-2016 "FÓRUM SOBRE AS OFICINAS ËXPERIÊNCIAS MATEMÁTICA"-2016

Imagem

de Márcia Re: FÓRUM SOBRE AS OFICINAS ËXPERIÊNCIAS MATEMÁTICA"-2016

Aparecida por Márcia Aparecida Lara - quinta, 31 Mar 2016, 19:10

Lara

Boa Noite, Prof. Stela, tudo bem?

Minhas aulas com a turma ocorre só um dia da semana, confesso que ainda estou um pouco perdida, ainda não instalei o jogo no mel celular, nas minhas aulas estou reforçando o conteúdo trabalhado pela professora, vou conversar com a prof. Roseli para juntos podermos ver em qual conteúdo o jogo se encaixa e com o apoio do prof. Bosco tenho a certeza que tudo dará certo.

Quanto deixar o grupo jogar com certeza deixarei e observarei também.

Sem mais desde já agradeço

Mostrar principal | Responder

Veja esta mensagem em seu contexto

Boa tarde, Professora Stela

Referente a experiência com o professor Bosco (jogos on lines), nas aulas de experiências matemáticas, achei muito importante e contribui bastante para notar algumas habilidades dos alunos em matemática, como por exemplo: explorar gráficos nos jogos, juntamente com a porcentagem e facilidades para resolver problemas contendo regra de três...

Re: FÓRUM SOBRE AS OFICINAS ËXPERIÊNCIAS MATEMÁTICA"-2016

por João José Bignetti Bechara - sábado, 2 Abr 2016, 01:25

Muito legal, Roseli. Parabéns!

Acredito que possamos alcançar resultados surpreendentes utilizando esta metodologia que estamos experimentando desde o ano passado. Ou seja, primeiramente permitindo que os alunos utilizem os jogos selecionados de forma independente. Incentivando-os depois a discutir e compartilhar suas conquistas e dificuldades através, por exemplo, de ferramentas sociais como WhatsApp e Facebook. E, posteriormente, utilizando sessões de "grupos focais" conduzidos pelos professores nas oficinas, obter deles os seus comentários, seus sentimentos sobre esta participação e os resultados alcançados alinhando-os com os objetivos de aprendizagem.

Vale destacar que "resolver e elaborar problemas" é parte essencial desses objetivos apresentados na Base Nacional Comum.

Mais uma vez parabéns. Grande abraço.

Mostrar principal | Responder

Veja esta mensagem em seu contexto 
Apêndice I

Planejamento Da Oficina Experiências Matemáticas Com Uso De Jogos Digitais 
ESCOLA ESTADUAL FERNANDO NOBRE

Endereço: Rua Riacho Grande $n^{\circ} 50$ - Jd. Guerreiro - Cotia - SP

E-mail: e010509a @see.sp.gov.br_ Blog: HTTP://oficinanobre. blogspot.com Fone: 47022326/4617-4305

Disciplina: EXPERIÊNCIAS MATEMÁTICAS

Turma: $8^{\circ}$ Ano B - FUND. II

№ de aulas previstas:

Nome do Professor: Adalberto Bosco Castro Pereira

\begin{tabular}{|c|c|}
\hline \multicolumn{2}{|c|}{ PROPOSTA CURRICULAR OFICIAL } \\
\hline \begin{tabular}{ll}
\multicolumn{1}{c}{ CONTEÚDOS } \\
- & Proporcionalidade \\
- & Variação de grandezas direta ou \\
inversamente proporcionais Conceito de \\
razão \\
- $\quad$ Porcentagem \\
- Razões constantes na Geometria: \\
Construção de gráficos de setores \\
Problemas envolvendo probabilidade \\
Realizar operações simples com monômios \\
e polinômios
\end{tabular} & $\begin{array}{l}\text { Habilidades } \\
\text { - Saber reconhecer situações que envolvem } \\
\text { proporcionalidade em diferentes contextos, } \\
\text { compreendendo a ideia de grandezas direta } \\
\text { e inversamente proporcionais. } \\
\text { - Saber resolver problemas variados, } \\
\text { envolvendo grandezas direta e inversamente } \\
\text { proporcionais. } \\
\text { Reconhecer e saber utilizar o conceito de } \\
\text { razão em diversos contextos } \\
\text { (proporcionalidade, escala, velocidade, } \\
\text { porcentagem etc.), bem como na construção } \\
\text { de gráficos de setores. } \\
\text { Resolver problemas simples de matemática } \\
\text { discreta, buscando soluções inteiras de } \\
\text { equações lineares com duas incógnitas. } \\
\text { Saber resolver problemas simples }\end{array}$ \\
\hline
\end{tabular}

PLANO DE PROFESSOR

Atividades propostas através de jogos móveis digitais. Criar perfil na rede social Facebook e Whatsapp (opicional) e adicionar os alunos. Indicar os jogos para os alunos jogarem livremente.

Explicar que o jogo contém desafios matemáticos diretos e indiretos, o jogo envolve a administração da cidade, que envolve alocação de recursos para diversas áreas, por exemplo: decisões envolvendo onde gastar a quantidade limitada dinheiro pode prejudicar ou ajudar o desempenho no jogo em curto, médio e longo prazo. Ficar à disposição para tirar a dúvida do jogo, além de jogar com os alunos. Solicitar que os alunos compartilhem seus feitos no jogo nos grupos criados para este fim. Fazer grupos focais com os alunos para que os mesmos digam o que foi aprendido com o game e fazer ponte destes conhecimentos com o currículo escolar.

\section{SITUAÇÃO DE APRENDIZAGEM}

Habilidades esperadas para que os alunos desenvolvam as atividades relativas à Situação de Aprendizagem:

Saber resolver problemas variados propostos pelo jogo digital, envolvendo grandezas direta e inversamente proporcionais.

Compartilhar de informações dentro e fora do jogo pelas redes sociais.

Estimular os alunos ajudarem seus colegas a resolverem seus problemas.

Estimular os alunos a tirarem dúvidas de outros alunos que estejam com dificuldades nos jogos digitais.

Estimular discussão de estratégias diversas abordadas dento dos jogos digitais para solução de problemas.

Realizar grupos focais para que o aluno mostre para ele mesmo e outros colegas o que ele aprendeu com o jogo e que relações existem com o currículo escolar.

Figura I.1: Documento digitalizado 
Apêndice $\mathbf{J}$

Fotos Da Escola Fernando Nobre 

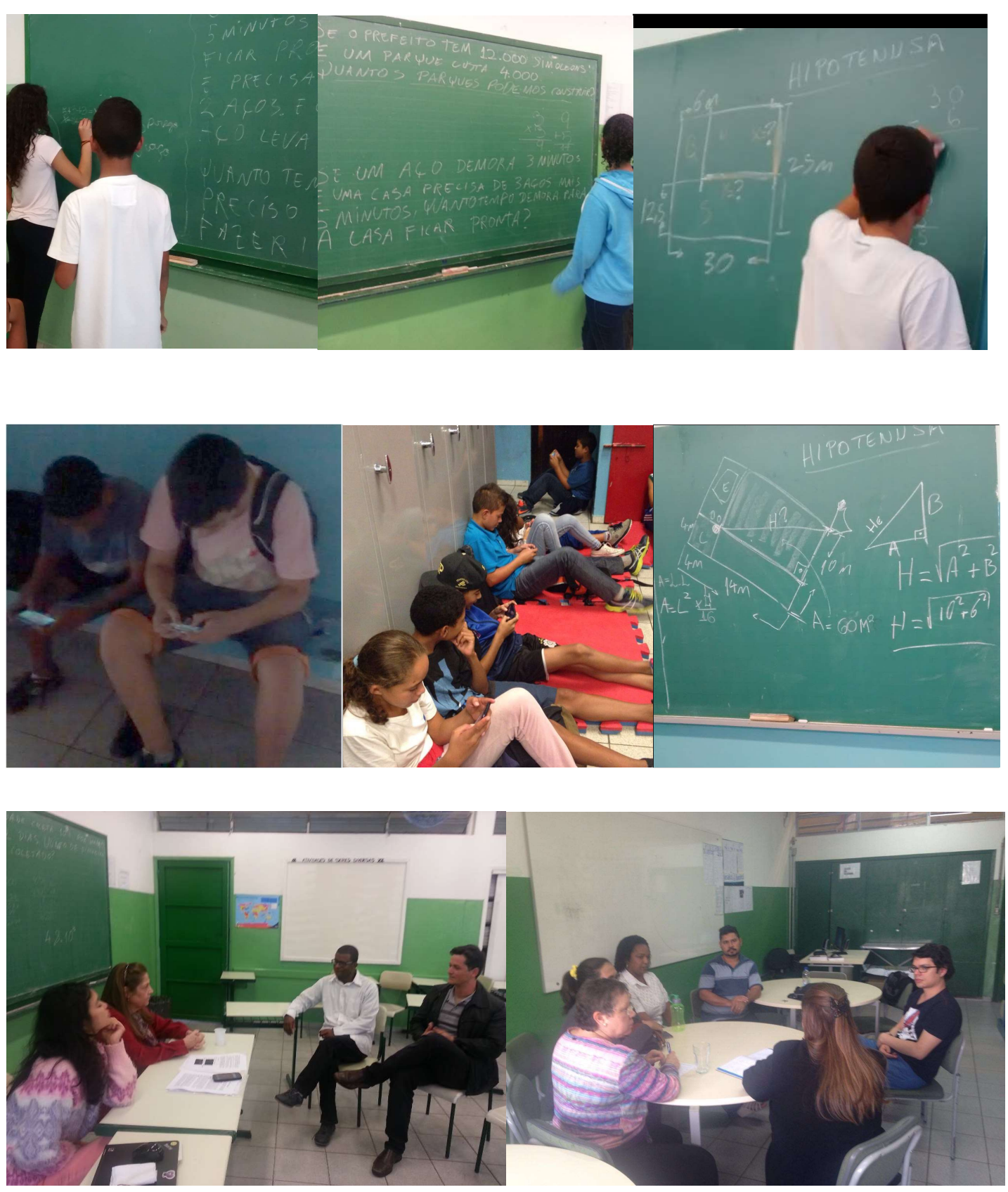

Figura J.1: Documento digitalizado 
Apêndice K

Diário De Campo 


\begin{tabular}{|c|l|}
\hline LOCAL: & DATA: \\
\hline Escola Estadual Fernando Nobre (laboratório de informática) & $12 / 05 / 2015$ \\
\hline
\end{tabular}

\begin{tabular}{|c|}
\hline OBJETIVOS \\
\hline - Orientações Preliminares sobre uso dos game escolhido com a professora Márcia \\
- Discutir alternativas metodológicas para usar com os alunos e os games \\
- Dialogar e orientar os alunos sobre o uso do celular e o game escolhido \\
\hline Mostrar outros jogos para as meninas \\
\hline
\end{tabular}
Parte DESCRITIVA

Chegamos na escola por volta das 13:30; a aula já estava acontecendo. Primeiramente, entramos em contato com o diretor, para ter acesso a internet e o mesmo não estava nem a internet estava funcionando, o que atrapalhou de início o experimento do dia, dado que precisaria ter acesso a nuvem para verificar o material que estava organizado e para que os alunos pudessem baixar os jogos sugeridos. Os alunos estavam ansiosos e excitados aguardando pela atividade planejada com os games.

$\mathrm{Na}$ sala com os alunos, abordamos as meninas sobre as razões pelas quais não queriam jogar o game escolhido. Muitas revelaram dificuldades de acesso em seus celulares; outras, não gostavam deste tipo de jogo ou mesmo não pretendiam jogar. Uma delas disse que não queria usar jogos pois seu pai disse que jogo é coisa inútil. Sugerimos jogos alternativos; ao citar Candy Crush Saga elas acharam bom, mas quando citei o The Sims elas soltaram uma exclamação de entusiasmo e mesmo as que não queriam jogar, nesse momento, passaram a ter maior interesse em jogar.

O projeto previa adesão espontânea e para maior consenso ficou combinado que iríamos usar o The Sims com o grupo de meninos e meninas que não demonstraram interesse a princípio no Clash of Clans. Estes alunos foram, então, também adicionados ao FaceBook e Whatsapp.

Neste meio tempo, fomos atender a turma $8^{\circ} \mathrm{b}$, escolhida pela professora Roseli, coordenadora da Oficina de Matemática, onde o jogo Sim City foi escolhido por eles. O professor de Ciências cedeu 20 minutos de sua aula para me apresentar a turma e o jogo, e então ficou acordado com os alunos que demonstraram muito interesse, de adicionar no Facebook e adicionar os mesmos no grupo criado para o jogo e experiências matemáticas com o game. Um dos alunos deu a ideia de usar o Skype ou Whatapp, falou que pelo Whatsapp é muito melhor. Consideramos a ideia favorável para a pesquisa pois adicionei-me ao grupo assim como minha orientadora Profa. Stela.

De volta à turma do $9^{\circ} \mathrm{B}$, verificou-se que os alunos que queriam e sugeriram usar o Clash of Clans estavam muito avançados no jogo. Explicavam estratégias de guerra, de ataque e de defesa da aldeia que construíram, e nos ajudaram a melhorar minha vila para me proteger de ataques inimigos.

Paralelamente, fui orientado a estudar e pesquisar nas resoluções e documentos educacionais, assim como no livro didático de Matemática, quais as competências poderiam ser articuladas às estratégias dos jogos. Os alunos não souberam deste nosso estudo. Apenas jogavam. Foi verificado junto à professora de Matemática, as maiores dificuldades dos alunos, o que seria necessário contemplar para atribuir sentido e significado posteriormente à fase de jogar. Tive oportunidades de sondar em nossas conversas como os alunos entendiam do jogo como gráfico, que eles têm dificuldades; o jogo e as questões de porcentagem e muitos outros conceitos matemáticos existentes no ato de jogar como questões relacionando regra de 3 , com porcentagem e divisão de razão e que resultem em dízimas periódicas. Dessa forma, fui tomando conhecimento das dificuldades existentes em conhecimentos básicos de Matemática que eles tinham dúvidas. Foi percebido que eles sabiam o que era uma regra de 3 , mas não seguiam o algoritmo posto pela escola de solução do problema. Muitos aspectos emocionais estavam envolvidos também: a ansiedade em resolver uma questão quando pulavam etapas resultando no erro. Sugerimos um trabalho colaborativo entre três ou quatro alunos o que auxiliou tremendamente na solução compartilhada das dúvidas. Ao final de cada sessão da atividade com jogos era feito uma breve avaliação, recomendação para continuarem jogando e solicitávamos um breve resumo sobre o que haviam aprendido. Eles conseguiram reproduzir para os colegas suas auto-aprendizagens.

Parte INTERPRETATIVA

Desafios de transformação do espaço tradicional da sala de aula

Figura K.1: Documento digitalizado 
Foi notado uma dificuldade de trabalhar com a turma muito grande, por estarmos em um espaço mais livre que a sala de aula, onde eles podiam andar, se comunicar com todos os colegas, sentar perto de quem apreciava o mesmo jogo etc. A euforia da turma era grande. Todos estavam imensamente entusiasmados e falavam ao mesmo tempo. A professora Roseli fazia intervenções para ajudar com uma "suposta" disciplina de sala de aula. Com a atividade deste dia centramos nossa atenção na avaliação de apenas o grupo de 4 alunos que tinham conhecimento e afinidade no jogo escolhido. Os alunos que não se interessaram pelo jogo escolhido faziam atividades diversas em papelaria cedida pela professora, como era de costume.

\section{Interesse para aprender}

Ao chegar na sala de aula fomos recepcionado com gritos de alegria e muito entusiasmo. Foi possível perceber que os alunos participantes estavam realmente engajados nas atividades com jogos digitais.

Ao percebermos falta de interesse do jogo Clash of Clãs por parte das garotas, que declinaram por não gostarem de jogo de estratégias (achamos que isto daria uma outra teses) sugerimos jogos alternativos como Candy Crush Saga e o mais aceito que foi o The Sims. Elas haviam dito que não gostavam de games mas ficou claro com essa indagação que elas não gostavam de certos tipos de jogos feitos para o público masculino, mas que havia sim interesse por jogos digitais.

Conversar sobre o jogo favorece o interesse do aluno em dialogar e tentar resolver os problemas e questionamentos propostos.

\section{Inferências}

- Uma pergunta feita pode gerar respostas incompletas ou com ruídos que podem levar à uma interpretação diferente da realidade, como no caso de garotas que gostam de um tipo de jogo afirmarem que não gostam de jogo nenhum.

- A comunicação e um diálogo aprofundado pode favorecer o uso de habilidades prévias do aluno em direção à solução de problemas diferentes dessa forma, transcender o que foi aprendido no jogo para outras áreas.

- Existem desafios disciplinares quando há maior liberdade e flexibilidade de ação, protagonismo dos alunos que assustam os professores. 
Apêndice L

Grupo Focal-Transcrição 
Legenda: S - professora Stela; B - Professor Bosco; A letra A caracteriza os alunos com nomes fictícios. S. Vocês gostaram desse jogo?

A1. Sim

S. Levanta a mão quem gostou. (todos)

$\mathrm{S}$. Um de vocês me responda o que era o jogo?

A2. Eu acho que o jogo serve para mostrar seu desempenho seu cuidado seu raciocínio

$\mathrm{S}$. Ah é?

A2. é como que você vai fazendo porque tipo lá você começa com uma quantidade de dinheiro ai você tipo tem que fazer como gastar aquele dinheiro dá pra tudo que você quer, ai é uma questão de estratégia como que você cria suas coisas...

$\mathrm{S}$. e você percebeu tudo isso?

A2.sim,

$\mathrm{S}$. isso mesmo, qual seu nome,

A2. Rodrigo,

Stela - isso mesmo Rodrigo, essas coisas acontecem com o jogo, o jogo não é só para diversão.

A2. ai também tem que ver lá que é... que aí pra testar suas qualidade, que ai você constroi suas casas ai tem os moradores ai tem vezes que aparece uma bolilha lá com a carinha vermelha, pq está ruim morando perto de fábrica.

$\mathrm{S}$. e seu colega do lado? Você gostou do jogo?

A1. Gostei

Bosco - Por que?

A1. Por causa que.. é... ensina a economizar e tudo isso que le falou também, que sê vai aprender a melhorar a cidade com o tempo mas não gastando tanto,

S. Você fica responsável pela sua cidade.

A1. Você fica responsável pela sua cidade.

$\mathrm{S}$. Voce pela sua e ele (A2) pela dele?

A1. Sim pq eu sou prefeito né? ai aparece umas bolinha vermelha ai quando ta triste ta muito perto das fabricas ai tem que trocar eles de local e gastar mais na cidade.

Bosco - E você do lado, que que você achou do jogo? o que mais te chamou atenção?

A3. Tipo pra se divertir assim e a mesma coisa que ele pra na administração de seu dinheiro lá no jogo, se você gastar tudo você nao consegue fazer mais nada, tipo...

S. Você acha que é fácil administrar dinheiro?

A3 - Mais ou menos, no jogo.

$\mathrm{S}$. Você ganha mesada? você trabalha, alguma coisa assim?

A3 - Eu colo lá as casinhas e elas começa a dar tipo dinheiro.

S. não não, na sua vida.

A3 - Ah, na minha vida normal?

A3 - na minha vida ganho,

S. Vc faz bicos, trabalha por fora?

A3 - não

S. não tem problema. E a menina? Vocês podem falar o nome porque eu não conheço todos vocês.

A4 - Cecília, eu achei o jogo legal, porque ele ensina bastante coisa e.. é meio difícil quando comandar o dinheiro pq tem coisa que a gente precisa mas não tem dinheiro suficiente pra gente comprar e a nossa cidade acaba pegando fogo (risos, dela e de colegas)

S. Você pode ter uma noção de como é difícil ser prefeito de uma cidade. (8:55) imagina a grande São Paulo que tem uns 25 milhões de pessoas, imagina, água esgoto pra todo mundo,

A5 - eu achei legal porque ensina a administrar o dinheiro, o meu eu não consegui administrar porque eu achei muito difícil (risos) ai eu fiquei só com 15 , eu fiquei com mais moeda que o dinheirinho verde lá.

S. você fez plano?

A5 - Não

Bosco - não fez plano? Você acha que possível de repente a gente administrar alguma coisa sem fazer plano?

A5 - não

S exatamente, e você, qual seu nome?

A6. Moisés

(falando com o joao que chegou)

$\mathrm{S}$. Moisés? nome bíblico né? que que vc achou?

A6 - o legal do jogo é que você ganha dinheiro lá no (não entendi) da fábrica ou vc é do prefeito lá eu achei bem da hora pq vc tipo se um dia voce for um prefeito vc já sabe como fazer

$\mathrm{S}$. é, se um dia vc for um prefeito, $n$ precisa nem ser prefeito, gerente né? no comércio, de alguma coisa, vc já sabe que tem que administrar o que entra o que sai, não é? então estou contente, vocês entenderam o jogo. Agora vou fazer com vocês, não vou falar nada, ok, só os que estão fora que vão falar. Vamos dizer que vocês sejam o grupo verbalizador, os que falam, e eles são o grupo observador, que vão observar, então vocês que não jogaram, eu queria, pode ser qualquer um né, o que que impediu o fato de vocês não jogarem, pode falar você.

A7. O meu celular estava sem espaço.

(Alunos falam junto)

A7, meu celular não deu pq não tem espaço

$\mathrm{S}$. Seu celular não tem espaço? O celular de vocês é o que? android?

Coro de alunos. é

S. O android que dá pra baixar coisas?

S. é.. mas como eu não conheço muito, o android vc tem que pagar por exemplo pra baixar?

Coro de alunos. Não, depende do aplicativo

A2, Só se for pro Iphone que tem que pagar a maioria dos jogos.

S. Tá, e também tem um detalhe se você com telefone entupido de coisa não dá para baixar né? algum aluno. é o meu tem um monte de foto.

$\mathrm{S}$. tudo bem, e você?

inaldivel

S. Eu não ouvi querido.

A8. Meu wifi estava muito lenta.

S seu wifi?

(alunos falam, S pede só pra A8 falar)

A8 sim

S Wifi lenta, a onde vc acessa, na sua casa? ou aqui?

A8 em casa

S na sua casa, e vc tem wifi?

A8 umhum, é da minha mãe

$\mathrm{S}$ da sua mãe, e é lenta?

A8 sim no meu celular. 
Bosco - e vc?

A9 Lá na praça tem wifi de graça

Bosco - então na praça tem wifi de graça?

Aluna Uxi, não sabia não.

Bosco - mas no seu caso vc não jogou por isso?

A9 meu celular estava travando, muito cheio.

S. e vc?

10 eu não tenho wifi

$S$ vc não tem wifi em casa, uma boa razão não é? e voce?

(fala sobre pq não jogaram foi ignorada nessa parte) (ninguem teve dificuldade de baixar o jogo)

20" continuar...

S.Só vocês que jogaram então. Eu gostei muito da fala de todos, porque você disse o seguinte: você teve que aprender a administrar o seu dinheiro, né? A2. Um hum

S. Então administrar eu posso também chamar de gerenciar, gerenciar a economia que tinha contida no jogo, tinha lá uns cálculos você que fez, eu não lembro, que calculo que você achou mais fácil de fazer? que que você achou mais difícil de fazer? A2.Como assim? Que calculo?

S.Você não tinha que calcular? quantos simoleons você tem, não era em dolar? né? de coisas que você tinha que gastar para construir uma casa, então, você fazia algum cálculo?

A2. mais ai tipo, Eu não fui de fazer isso.

S.Não? e como você tinha dinheiro e podia gastar mais?

A2. Não entendi, fala de novo?

S.Bosco você pode me ajudar na pergunta.

B. Na hora que tu tinhas por exemplo, construir um parque, tu tinhas que construir uma delegacia e outra coisa, mas ai tu tinhas um dinheiro lá, como é que tu fazias?

A2 ah, entendeu, tipo, eu, vamo supor, se eu tivesse que construir um parque e depois vamo supor uma fábrica, ai eu tinha pouco dinheiro, vamos supor uns 6.000 , ai eu tipo não ia poder construir a fábrica porque era mais importante.

B. Sim

A2. Ai você fala assim?

B. é.

A2 não entendi muito bem assim.

B. E por exemplo quando tu tinhas que melhorar uma casa e ai tinha alguns recursos que tu precisarias pra essa casa como é que tu fazia? tu planejavas para construir essas coisas? ele pedia sempre um número diferente né? e ai tem que ver o que que precisa pra construir isso, como é que tu fazia?

A2.Pra transformar né? pra fazer de um prédio?

B. Isso

A2. quando tipo, que nem quando eu pedia lá e as bigorna e os 3 martelo, ai eu ia primeiro lá nas fábrica e fazia.

Aluno fora. E como que fazia pra ganhar dinheiro nesse jogo?

A2. Tinha que fazer a mansão do prefeito, ai começa a ganhar dinheiro e o negócio lá de item, e tem um negócio lá professor que tem uma casa, é, uma, tipo uma fábrica, ai tem um negócio lá que tem uns negócinhos uns pininhos que vai subindo lá, ele mostra um dinheiro que você ganha. é...

$\mathrm{S}$. Você falou uma coisa legal, me diga se eu tiver errada, você disse que tinha que ter prioridades, é isso? Você tinha que escolher a melhor solução.. A2. é

S. pra escolher a melhor solução você tinha que levantar essa, essa, essa e escolher uma, dar prioridades pra uma delas.

A2. é.

$\mathrm{S}$. é mais ou menos o que acontece na nossa vida. Você levanta de manhã e vai dar prioridade a que? a coisas que você planejou pra fazer durante do dia, seja uma tarefa da escola, seja uma tarefa que sua mãe te deu, né? Seja uma tarefa de um sonho que você tem, não é isso? Então eu acho bacana, então você na verdade, você é... ficava trabalhando com essas prioridades. (S para B) tinha por exemplo, eles chegaram naquela parte que se ele construísse mais escolas ele não precisava construir muita cadeia?

B. Não, não chegou.

S. mais então vocês chegaram a que nível? Se vocês construíssem mais escolas você diminui, a prioridade não é mais construir cadeia, porque será? A4. Porque as pessoas vão estudar e não vão ficar na rua

S. Exato, porque as pessoas vão estudar e vão perceber que tem certas coisas que não pode fazer sem estudo. São leis do país, regras, não é? Se eu fizer errado, como a gente vê aí na mídia, o cara vai preso, por roubar, matar, né? assim por diante. Vocês vão chegar nesse nível se quiserem continuar jogando.

A2. Que nível é esse mais ou menos?

B. Lá pro 20, 25.

A3. ô professor. eu cheguei no nível 10, eu já liberei a educação e o transporte.

B. Aí, se construir o transporte de ônibus por exemplo, ele diminui o trânsito.

A3. eu já consegui, eu já melhorei, como fala?, as rodovias da cidade, o asfalto.

$\mathrm{S}$. Então você priorizou a educação e o transporte? A3. é, aham.

S. e você priorizou o quanto tinha de dinheiro certo? (para A2)

A2. é mais tipo, é pq eu reseitei o celular ai eu vou ter que instalar de novo.

S. Muito bem.

B. Mas se você colocou lá no FaceBook fica salvo e todos podem ver o nível que você está.

A2, tá que eu até acessei lá.

S.E você, o que você por exemplo, fez algum planejamento na sua cabeça? só com os pensamentos?

A3. Sim, quando tem que melhorar é.. as casas, fábrica lá, tem que, a quantidade de cada item que tem que fazer, eu conto primeiro pra depois começar indo fazendo, e fazendo na fábrica, ai depois eu vou lá e melhoro.

S. e você fez a análise, como? o número de casas... $B$. os recursos que precisava,

A3. tipo bigorna.

B. pra depois ir fazendo.

A3. Prego. 
S. Podia ter uma fábrica para aquelas pessoas que irem trabalhar, pra ter trabalho pra elas. Então você fez a análise e ao mesmo tempo você usou seu raciocínio crítico. Porque é isso que a gente precisa, as vezes vocês vão no shopping, vão passear, né? e o papai e a mamãe dá alguma coisa, um dinheirinho para vocês gastarem, vocês priorizam? vocês olham para a vitrine e vão gastando logo de cara e depois fica sem nada?

A4. Eu não gasto, eu junto dinheiro, eu jogo tudo no meu cofrinho, pode ser o dinheiro que for eu guardo, eu tipo assim, me dá 100 reais, eu pego 20 reais

A3 Eu escolho o mais barato

A1 é a gente vai vendo os preços quando você ver que vai, é tipo.. você vê um produto, aquele produto ele é bom mais ele é caro, você vê um melhor ainda mais é barato, melhor comprar um barato do que... $\mathrm{S}$. então você ta fazendo a análise usando seu raciocínio crítico, planejando e depois você prioriza, vou comprar aquele que é bonito também mais é mais barato, né? até porque nós estamos vivendo um momento de crise, e crise precisa economizar, né? Mas é sempre assim, agora mais ainda. $E$ você? você falou um negócio bacana também, que você percebeu quando estava jogando.

A3. Eu gasto mais a moeda de ouro, do que em dolar, porque a moeda de ouro é mais fácil de se conquistar, como se fosse, eu tenho as fábricas de alimento, ai vai ai já tá liberado lá ai tem pessoas que querendo comprar por 200 de moeda, ai eu vendo já, ai consegue recuperar mais fácil do que em dolar, aquelas.

S. Nossa, você vai ser um excelente comerciante heim... Você também fez isso, você tinha duas opções de gasto, você viu o que era melhor pra você no momento e você priorizou a moeda de ouro, e percebendo que as pessoas compravam mais facilmente né? isso também é importante para a nossa vida fazer isso. $E$ você?

A4 Eu?

S. Houve algum planejamento? algum cálculo que você precisou fazer? de cabeça?

A4. eu tipo só peguei mais pra fazer lazer pra eles, por causa que se não eles iam embora.

$\mathrm{S}$. Você percebeu que lazer é muito importante?

A4 Hum Hum.

S. Também acho. Na nossa constituição, brasileiro, todo brasileiro tem direito a educação, saúde, segurança e lazer. só que nós temos todos os parques, mas nada é gratuito, quase tudo pago, mas você priorizou o lazer, você achou que na cidade era importante. Qual a consequência de você ter priorizado o lazer? Deixou de construir alguma coisa?

B. Pegou fogo?

A4 Não, pegar fogo num pegou fogo não.

$\mathrm{S}$. que nível que você chegou?

A4. Eu, eu tava no nível 12. Ai depois.

B. você não chegou a conectar no FaceBook não né? porque eu não consegui ver tua cidade.

A4. Hum...hum.

S. porque, se um prefeito também só priorizar o lazer B. é, se não construir as delegacias, e o posto de bombeiro pega fogo a cidade.
S. Veja você que interessante, está correto, tem que dar lazer, eu acho que o lazer é importante, mas quando você na vida normal, quando você for mais adulto as vezes a prioridade que eu tenho é boa pra mim, mas não é boa pra quem convive comigo, com meus irmãos, pra minha mãe, pro meu pai, não é boa para a cidade, por que por exemplo tem aquelas pessoas que priorizam droga? né? cigarro, bebida? e outras drogas... Eles já sabem, e já estão informados que aquilo faz mal para saúde, de repente ele prioriza por que acha que é ???????

A4. Hum hum.

S. então você também fez a análise. né? você chegou a escolher uma prioridade? Agora precisa ver se a sua cidade, depois comparando com as outras cidades de seus colegas o que vai ter de diferente, vai ter uma diferença ai?

A3. O ruim agora na minha cidade é os prédios por que quase todas as casas que tem que melhorar tem que ter bastante recursos pra poder evoluir, por isso que eu to parado no nível 8.

S. O que que você por exemplo, lembra de uma época, uma situação que você estava em casa pensando, estava jogando, deu uma parada olhou pro alto, falou: 'Ai meu Deus, como eu faço isso aqui?' você fez algum cálculo, algum plano? Você pensou como seus colegas?

A5 - Quando, teve uma vez que estava pedindo pra comprar uma fábrica e uma casa, ai eu pensei parei e comprei a fábrica, porque lá produz os materiais que eu vou precisar pra fazer a, pra melhorar a casa depois, e quando tem bastante material tem gente que quer comprar ai eu vendo, consigo dinheiro e compro a casa .

S. Ela fez uma operação inversa, ao contrário do que eles fizeram ao invés de construir uma casa, construiu primeiro uma indústria, porque ela vai me permitir vender para eu poder construir casas, não é isso? muito bem.

A3. Professora... os que mais reclamam são os que moram perto da fábrica e usina elétrica,

$S$. que usina é?

A3 a usina elétrica.

S. Usina elétrica... E você pensou sobre isso? Porque?

A3. Faz muito barulho e a fumaça.

S. Poluição? Ah, então vocês estão entrando ai num outro raciocínio, interessante, porque vocês estão pensando na cidadania, não é isso? Em termos de cidadania, vocês já viram que a educação é fundamental, o transporte da cidade é fundamental, o lazer é fundamental, a poluição, evitar a poluição, que as fábricas fazem com o tempo, temos que pensar em tudo isso? Então quando vocês pensam assim, quando vocês pensam sobre isso, vocês pensam só pra vocês ou vocês pensam pra cidade como um todo?

A2. Pra cidade.

A1. você pode repetir a pergunta por favor?

S. Quando vocês forem recorrer a alguma solução, a sua escolha é baseada naquilo que você acha que é bom pra você ou que é bom pra todos na cidade? A1 pra todos na cidade, porque é igual esgoto, eu comprei o negócio lá de esgoto e coloquei perto da casa, mas ai o povo tava reclamando, ai eu fiz outro 
espaço lá e coloquei lá no finalzinho, e coloquei esgoto, a usina elétrica o negócio de água e.. é só esses.

S. então você estava preocupado com o saneamento básico da cidade. Até porque não adianta nada você pensar no lazer, na educação, no transporte se não tiver feito nada de água, esgoto, a cidade precisa dessa base né? muito bom.

\section{A2. Professora.}

Stela - Um minutinho. E você?

A5. Eu construí 3 casas e ai teve uma que estava quase pegando fogo, estava com risco de incêndio, e tinha 3 pra aprimorar, ai primeiro eu fiz bastante material de construção, ai terminei as casas, depois coloquei o corpo de bombeiros, e depois fiz mais outra casa, coloquei mais outras áreas,

S. Muito bem, então você fez tudo isso aqui, você priorizou, você pensou numa solução, né? você estava com um problema real, escolheu um priorizou e conseguiu resolver o problema. Olha eu estou muito contente com essa observação de vocês

A3 a gente também tem que ouvir os balãozinhos da população, porque as vezes eles pedem pra ter mais vizinhos, as vezes tem que fazer, melhorar a energia quando está faltando, dão presentes pra aprimorar o armazém.

S. Então vocês acham que por exemplo na nossa cidade aqui os políticos são responsáveis né?

A3 Não, não. Os políticos não ouvem os moradores da cidade.

A1 eu vi no jornal que perto de um condomínio, tinha logo um terreno e nesse terreno só tinha lixo, jogava lixo lá e por causa desse lixo, é... tinha um monte de dengue lá ai trazia perigo lá pro condomínio.

S. então isso faz parte do saneamento básico, a questão do lixo e da poluição, né? Muito bom.

A2 professora Stela?

E sobre o jogo também, tem uma parte lá que parece uma fábrica la do comércio que a gente ganhamos ai sabe os balãozinhos? acho que todo mundo deve saber, que tem uns balaozinhos que dos prédios ou das casas dos moradores falam que estão gostando as opiniões, então ai tem uma parte lá, eu não lembro se é comércio ou é fábrica que conforme você vai ganhando aqueles balãozinhos você vai ganhando dolares, o dinheiro em papel, que ai vai ganhando... que tipo

$\mathrm{S}$. o bonus né?

A2 é um bonus, ai você ganha um bonus, ai tem uns balaozinhos ai eles vão falando dando as opiniões, se eles gostão ou não.

S. agora eu vou fazer uma coisa, que eu vi que vocês são espertos! O Bosco vai mostrar pra vocês uma expressão algébrica que vocês estudam na sala de aula baseado nesse jogo

Bosco - Eu vou fazer com vocês um trabalho aqui, uma questão de matemática parecida com os problemas que vocês resolveram no jogo. Então, vocês que jogaram, poderiam resolver este problema: para fazer 2 pregos a gente demora 30 minutos; quanto tempo demoraria para fazer 1 prego ficar pronto?

Bosco - Se eu tenho 12.000 de 'gold' e cada parque custa 4.000 , quantos parques eu posso construir com esse dinheiro?
Bosco - A população paga o imposto de acordo com a satisfação. Se a população paga 6.000 de imposto a cada 24 horas quando está $100 \%$ satisfeita, quanto a população pagaria em 24 horas se ela estivesse $80 \%$ satisfeita? 
Anexos 
Anexo A

Projeto De Tecnologias Digitais De Informação E Comunicação 


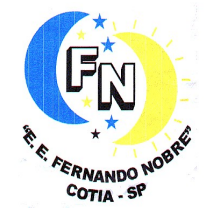

\section{ESCOLA ESTADUAL FERNANDO NOBRE}

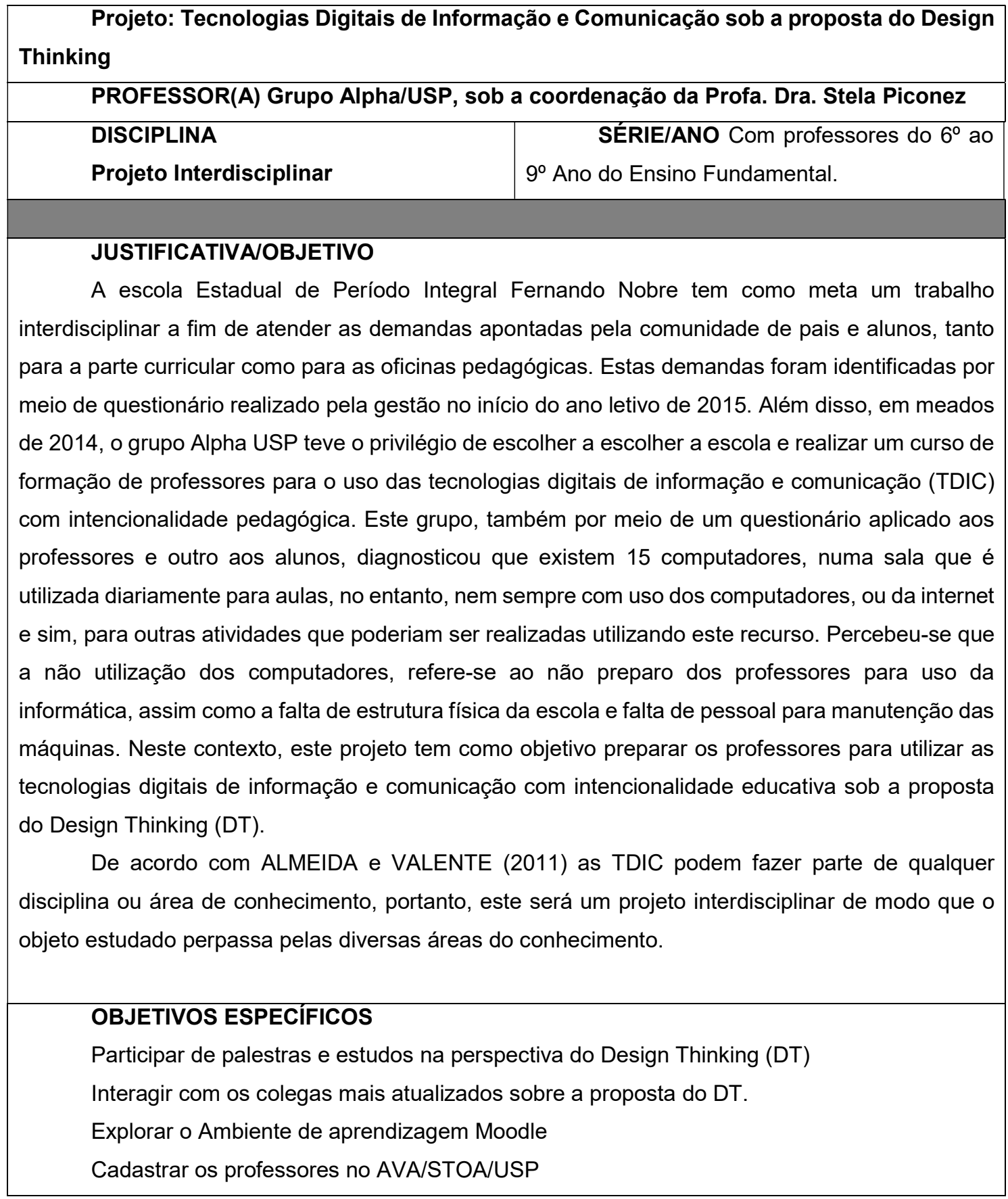

Figura A.1: Documento digitalizado 


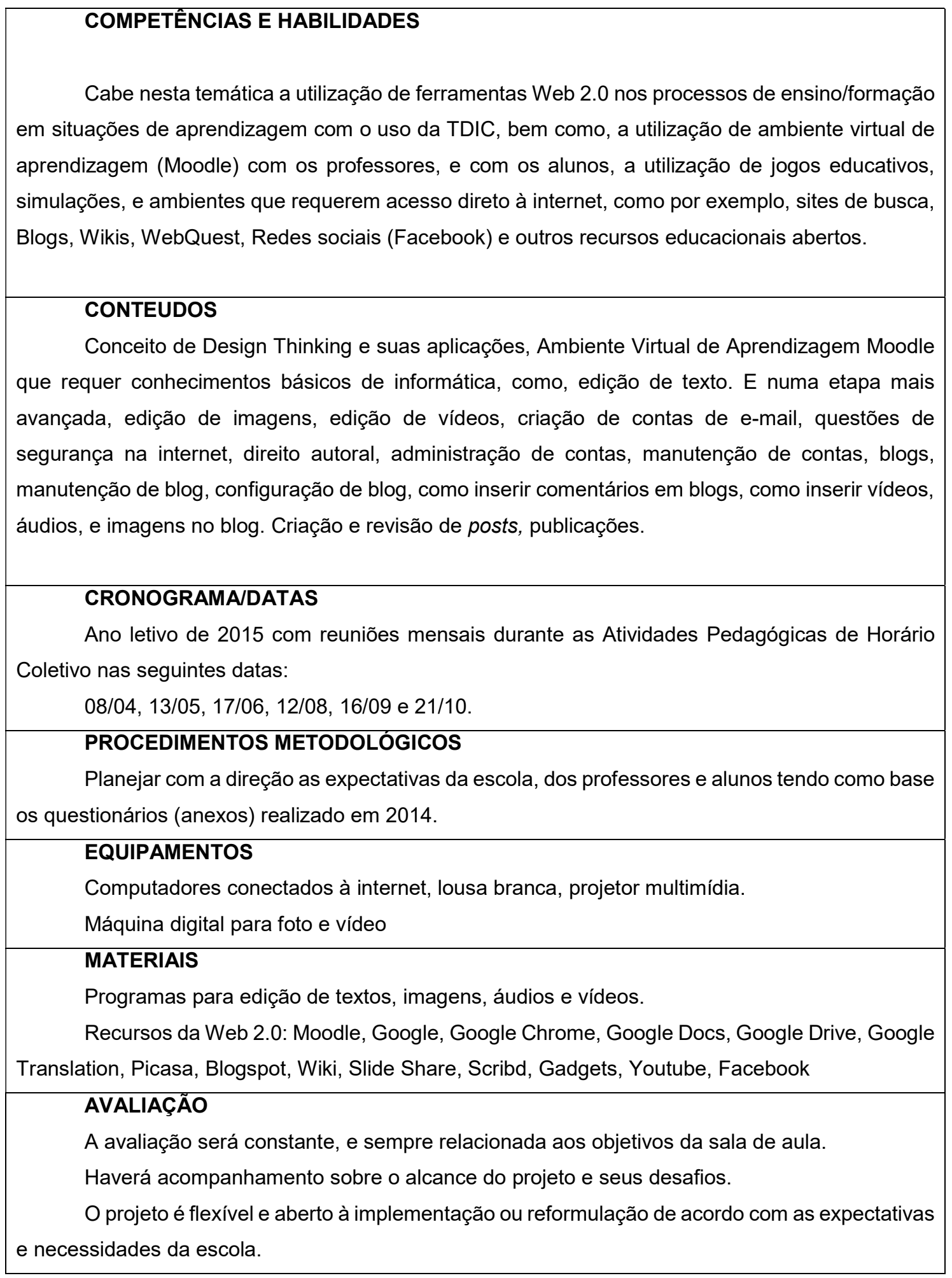




\section{REFERÊNCIAS}

ALMEIDA, M. E. B. e VALENTE, J. A. Tecnologias e currículo: trajetórias convergentes ou divergentes? São Paulo: Paulus, 2011.

ASSMMANN, Hugo; BOFF, Leonardo. Reencantar a Educação: Rumo à Sociedade Aprendente. 9. ed. Petrópolis: Vozes, 2007.

DT PARA EDUCADORES, disponível em http://www.dtparaeducadores.org.br/site/ Acessado em 04/04/2015.

FAZENDA, Ivani C. Arantes. Interdisciplinaridade: História teoria e pesquisa. 7. ed. Campinas: Papirus (Coleção Magistério: Formação e Trabalho Pedagógico), 2001.

MORAN, José Manuel. Educação Humanista Inovadora. Disponível em: http://www2.eca.usp.br/moran/

Acesso em: 23 fev. 2015.

VIGOTSKY, L. S. Pensamento e Linguagem ( $2^{a}$ ed. brasileira). (J. L. Camargo, Trad.). São Paulo: Martins Fontes, 1989.

PICONEZ, S. C. B. Entrevista sobre Alfabetização de Jovens e Adultos e formação continuada de professores. Disponivel em: http://www.miniweb.com.br/atualidade/entrevistas/Stela Piconez/profa stela.html Acessado em 04/04/2015.

ZIMMER, J. M. Blog Didático: integração na prática pedagógica. Dissertação de Mestrado em Comunicação Educacional e Multimedia. Universidade Aberta de Portugal, 2012. Disponível em:

https://repositorioaberto.uab.pt/bitstream/10400.2/2212/4/Vers\%C3\%A3o FINAL 010520 12 Josete.pdf

Acesso em: 23 fev. 2015. 
Anexo B

Planejamento Da Oficina Experiências Matemáticas Da Professora Roseli 
ESCOLA ESTADUAL FERNANDO NOBRE

Endereço: Rua Riacho Grande $n^{\circ} 50$ - Jd. Guerreiro - Cotia - SP

E-mail: e010509a @see.sp.gov.br-Blog: HTTP://oficinanobre. blogspot.com Fone: 4702-2326/4617-4305

Disciplina: EXPERIÊNCIAS MATEMÁTICAS

Turma: $7^{\circ}$ Ano A e B - FUND. II

№ de aulas previstas:

Nome do Professor: Roseli de Paula Ramos

\begin{tabular}{|c|c|}
\hline \multicolumn{2}{|c|}{ PROPOSTA CURRICULAR SEE } \\
\hline $\begin{array}{l}\text { CONTEÚDOS } \\
\text { Proporcionalidade } \\
\text { Variação de grandezas } \\
\text { direta ou inversamente } \\
\text { proporcionais Conceito } \\
\text { de razão } \\
\text { Porcentagem } \\
\text { Razões constantes na } \\
\text { Geometria: p Construção de } \\
\text { gráficos de setores Problemas } \\
\text { envolvendo probabilidade }\end{array}$ & $\begin{array}{l}\text { Habilidades } \\
\text { Saber reconhecer situações que envolvem } \\
\text { proporcionalidade em diferentes contextos, } \\
\text { compreendendo a ideia de grandezas direta e } \\
\text { inversamente proporcionais. } \\
\text { Saber resolver problemas variados, envolvendo } \\
\text { grandezas direta e inversamente proporcionais. } \\
\text { Reconhecer e saber utilizar o conceito de razão em } \\
\text { diversos contextos (proporcionalidade, escala, } \\
\text { velocidade, porcentagem etc.), bem como na } \\
\text { construção de gráficos de setores. } \\
\text { Conhecer o significado do número p como uma } \\
\text { razão constante da Geometria, sabendo utilizá-lo } \\
\text { para realizar cálculos simples envolvendo o } \\
\text { comprimento da circunferência ou de suas partes. } \\
\text { Saber resolver problemas simples } \\
\text { envolvendo a ideia de probabilidade } \\
\text { (porcentagem que representa possibilidades de } \\
\text { ocorrência). }\end{array}$ \\
\hline
\end{tabular}

\section{SITUAÇÃO DE APRENDIZAGEM}

Habilidades esperadas para que os alunos desenvolvam as atividades relativas à Situação de Aprendizagem do décimo bimestre:

1 - Saber resolver problemas variados, envolvendo grandezas direta e inversamente proporcionais.

2- Sequência das atividades de ensino-aprendizagem e avaliação contínua relativa à Situação de Aprendizagem 1 do $1^{\circ}$ bimestre: Introdução a porcentagem.

3- Materiais de apoio pedagógico relativo à Situação de Aprendizagem 1 do $1^{\circ}$ bimestre: Jogos, Xerox, papel sulfite, lápis de cor, canetinha, aquarela, cola, tesoura, cartolina e EVA.

4- Lições de casa previstas relativas à Situação de Aprendizagem 1 do $1^{\circ}$ bimestre: Trabalhos em grupos realizados em sala de aula - Jogo das frações.

5- Expectativas de aprendizagem relativas à Situação de Aprendizagem 1 do $1^{\circ}$ bimestre: Compreender as comparações entre sistemas de numeração, identificando semelhanças e diferenças entre eles.

6- Instrumentos de avaliação relativos à Situação de Aprendizagem 1 do 10 bimestre: Participação do aluno em sala de aula Interesse em participar das atividades Atividade pratica. Resolução das atividades em classe e extraclasse.

7- Proposta de recuperação contínua, relativa à Situação de Aprendizagem 1 do 10 bimestre: Atividades com exercícios sistema de numeração. 
ESCOLA ESTADUAL FERNANDO NOBRE

Endereço: Rua Riacho Grande ${ }^{\circ} 50$ - Jd. Guerreiro - Cotia - SP

E-mail: e010509a @see.sp.gov.br_ Blog: HTTP://oficinanobre. blogspot.com Fone: 4702-2326/4617-4305

Disciplina: EXPERIÊNCIAS MATEMÁTICAS

Turma: $9^{\circ}$ Ano A e B - FUND. II

№ de aulas previstas:

Nome do Professor: Roseli de Paula Ramos

\begin{tabular}{|c|c|}
\hline \multicolumn{2}{|c|}{ PROPOSTA CURRICULAR SEE } \\
\hline \begin{tabular}{l}
\multicolumn{1}{c}{ CONTEÚDOS } \\
Oficina de geometria Proporcionalidade na \\
Geometria O conceito de semelhança \\
Semelhança de triângulos \\
Razões trigonométricas
\end{tabular} & $\begin{array}{l}\text { HABILIDADES } \\
\text { Saber reconhecer a semelhança entre figuras } \\
\text { planas, a partir da igualdade das medidas dos } \\
\text { ângulos e da proporcionalidade entre as medidas } \\
\text { lineares correspondentes. Saber identificar } \\
\text { triângulos semelhantes e resolver situações- } \\
\text { problema envolvendo semelhança de } \\
\text { triângulos.Compreender e saber aplicar as } \\
\text { relações métricas dos triângulos retângulos, } \\
\text { particularmente o teorema de Pitágoras, na } \\
\text { resolução de problemas em diferentes } \\
\text { contextos.Compreender o significado das razões } \\
\text { trigonométricas fundamentais (seno, cosseno e } \\
\text { tangente) e saber utilizá-las para resolver } \\
\text { problemas em diferentes contextos. }\end{array}$ \\
\hline $\begin{array}{r}\text { Atividades propostas através de jogos p } \\
\text { relações métricas dos triângulos retângulos, } \\
\text { problemas }\end{array}$ & $\begin{array}{l}\text { udar os alunos a compreender e saber aplicar as } \\
\text { cularmente o teorema de Pitágoras, na resolução de } \\
\text { iferentes contextos. }\end{array}$ \\
\hline
\end{tabular}

\section{SITUAÇÃO DE APRENDIZAGEM}

1- Habilidades esperadas para que os alunos desenvolvam as atividades relativas à Situação de Aprendizagem do décimo bimestre:

1 - Saber reconhecer a semelhança entre figuras planas, a partir da igualdade das medidas dos ângulos e da proporcionalidade entre as medidas lineares correspondentes.

2- Sequência das atividades de ensino-aprendizagem e avaliação contínua relativa à Situação de Aprendizagem 1 do $1^{\circ}$ bimestre: Razões trigonométricas.

3- Materiais de apoio pedagógico relativo à Situação de Aprendizagem 1 do $1^{\circ}$ bimestre: Jogos, Xerox, papel sulfite, lápis de cor, canetinha, aquarela, cola, tesoura, cartolina e EVA.

4- Lições de casa previstas relativas à Situação de Aprendizagem 1 do $1^{\circ}$ bimestre: Trabalhos em grupos realizados em sala de aula - Jogo do vai e vem.

5- Expectativas de aprendizagem relativas à Situação de Aprendizagem 1 do $1^{\circ}$ bimestre: Compreender conjuntos numéricos.

6- Instrumentos de avaliação relativos à Situação de Aprendizagem 1 do 10 bimestre:

Participação do aluno em sala de aula Interesse em participar das atividades Atividade pratica. Resolução das atividades em classe e extraclasse.

7- Proposta de recuperação contínua, relativa à Situação de Aprendizagem 1 do 10 bimestre: Atividades envolvendo conjuntos numéricos. 
Anexo C

Grupo Aberto no Facebook 


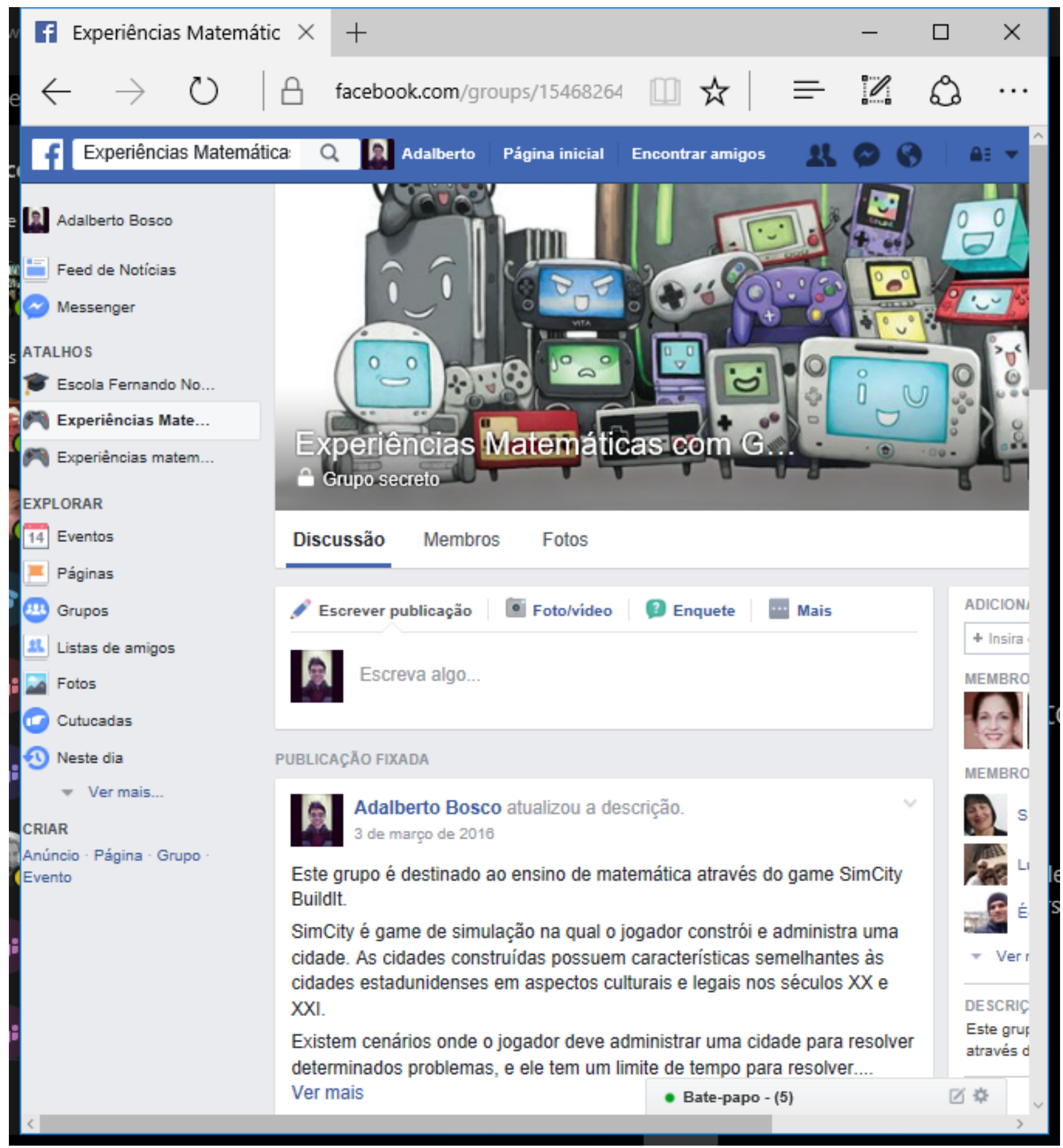

Figura C.1: Documento digitalizado 


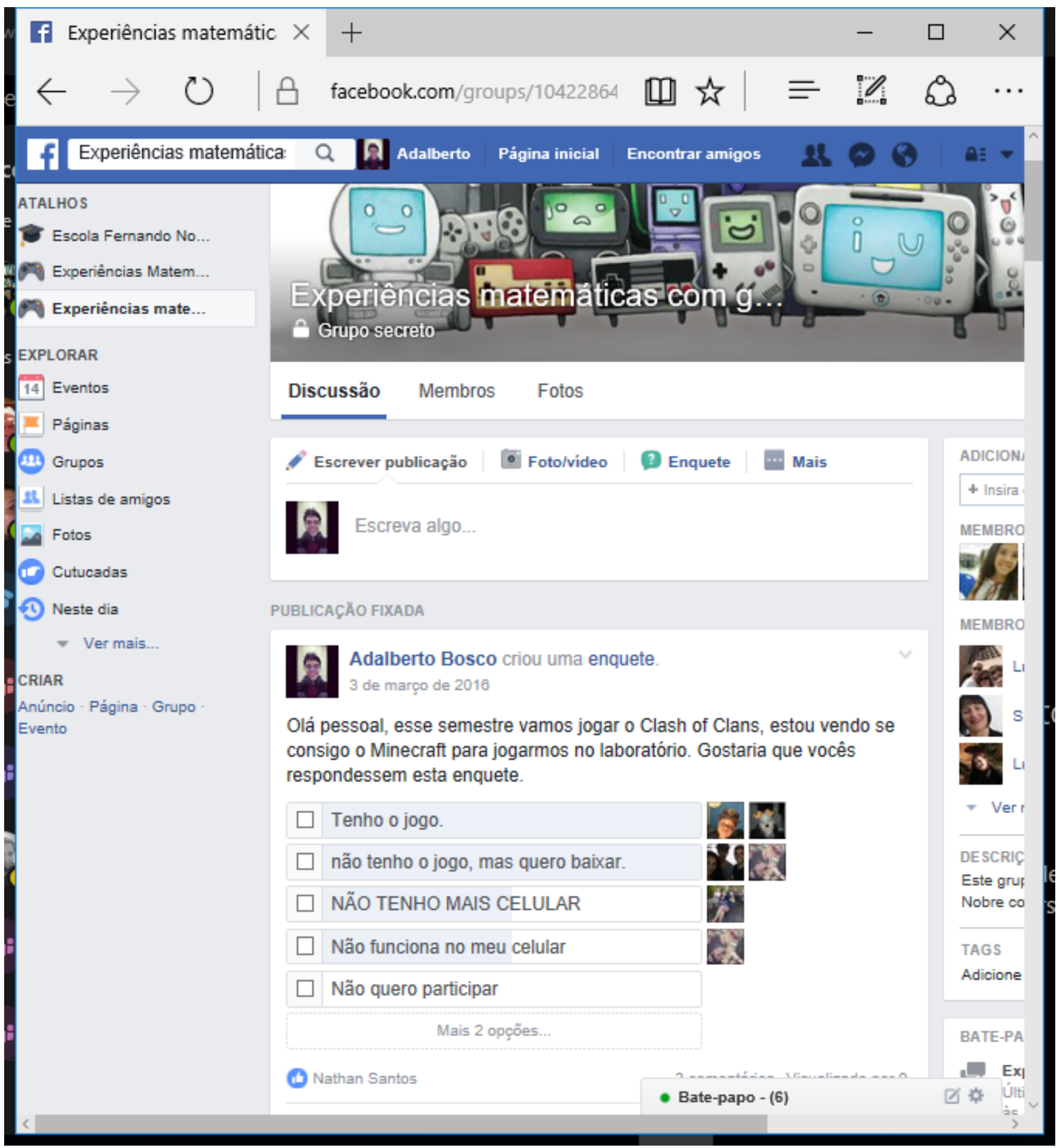

Figura C.2: Documento digitalizado 
Anexo D

Redes Sociais -Whatsapp 
Devido à grande quantidade de material, apenas uma parte do registro do Whatsapp e Facebook foram anexados para ilustrar o que foi feito.

\section{[...]}

30/09/15, 23:57 - Você criou o grupo "Experiências matemáticas"

30/09/15, 23:58 - Luiza (Fenando Nobre): MDS quem é?:i:

30/09/15, 23:58 - Bosco: Olá

30/09/15, 23:59 - Luiza (Fenando Nobre): Oi

30/09/15, 23:59 - Bosco: Aqui é o professor Bosco, desculpe o horário

30/09/15, 23:59 - Bosco: 궁

30/09/15, 23:59 - Luiza (Fenando Nobre): Magina

30/09/15, 23:59 - Luiza (Fenando Nobre): Que professod

30/09/15, 23:59 - Luiza (Fenando Nobre): Professor

30/09/15, 23:59 - Bosco: Criei esse grupo para trabalhar com vocês, tentei adicionar vocês no

facebook,

01/10/15, 00:00 - Bosco: Sou o professor Adalberto Bosco

01/10/15, 00:00 - Luiza (Fenando Nobre): Aaaaaa lembrei

01/10/15, 00:00 - Bosco: Estou trabalhando na escola Fernando nobre

01/10/15, 00:00 - Você alterou a imagem deste grupo

01/10/15, 00:01 - Luiza (Fenando Nobre): Professor, me desculpa... Mais podemos conversar

amanhã, estou meio cansada

01/10/15, 00:01 - Bosco: Claro

01/10/15, 00:01 - Bosco: Boa noite

01/10/15, 00:01 - Luiza (Fenando Nobre): Obrigada, para você também...

01/10/15, 09:59 - Bosco: Bom dia pessoal, depois me ajudem a por o número dos seus colegas que queiram participar que não consegui pegar.

01/10/15, 14:01 - Gustavo (Fenando Nobre): Demoro

01/10/15, 16:33 - Eduardo (Fenando Nobre): Ta

01/10/15, 16:54 - Bosco: Obrigado (-)

01/10/15, 17:26 - Bianca (Fenando Nobre): Oi

01/10/15, 17:31 - Bosco: Olá

01/10/15, 17:36 - Bianca (Fenando Nobre): Pra q serve esse grupo msm?

01/10/15, 17:44 - Bosco: Sou professor da oficina de experiências matemáticas da escola Fernando nobre e a professora Roseli e Márcia vamos criar atividades envolvendo games para ensinar matemática. Assim que as atividades estiverem prontas eu me reúno com vocês. Esse grupo vai servir para compartilharmos as atividades do game

01/10/15, 17:48 - Eduardo (Fenando Nobre): Kkkkk

01/10/15, 17:48 - Luiza (Fenando Nobre) saiu

01/10/15, 17:50 - Bianca (Fenando Nobre): Hm

01/10/15, 17:50 - Bianca (Fenando Nobre): Tendi

01/10/15, 17:51 - Bosco: Lembra que eu fui na escola pegar os contatos de vcs?

01/10/15, 17:51 - Bosco: $\odot$

01/10/15, 17:53 - Bianca (Fenando Nobre): Ss

01/10/15, 18:14 - Carla (Fenando Nobre): Sim

01/10/15, 18:15 - Aline (Fenando Nobre): Sim

01/10/15, 19:08 - Gustavo (Fenando Nobre): Salve galera como vai as coisas

01/10/15, 19:08 - Bianca (Fenando Nobre): Bem

01/10/15, 19:16 - Eduardo (Fenando Nobre): Hm

01/10/15, 19:24 - Bosco: Bem!

01/10/15, 19:36 - Gustavo (Fenando Nobre): lae bosco cade as atividades de games

01/10/15, 19:51 - Bosco: Calma, estou preparando o material ainda

01/10/15, 19:51 - Eduardo (Fenando Nobre): Tabom

01/10/15, 20:00 - Gustavo (Fenando Nobre): Ata

01/10/15, 20:00 - Gustavo (Fenando Nobre): Tendeu

01/10/15, 20:41 - Carla (Fenando Nobre): Bem

02/10/15, 16:28 - Aline (Fenando Nobre): Olá galera

02/10/15, 16:34 - Carla (Fenando Nobre): Olá

02/10/15, 16:34 - Aline (Fenando Nobre): :-8 
02/10/15, 16:52 - Bosco: Olá, ta calor hj, estão sem aula essa semana né?

02/10/15, 16:52 - Bosco: Estou estudando muito essa semana (i)

02/10/15, 17:03 - Eduardo (Fenando Nobre): Tabom

02/10/15, 21:52 - Gustavo (Fenando Nobre): <Mídia omitida>

02/10/15, 21:54 - Bosco: :-i)

06/10/15, 16:02 - Bosco: Olá pessoal

06/10/15, 16:03 - Bosco: Tudo bem por ai?

06/10/15, 17:39 - Carla (Fenando Nobre): Sim

06/10/15, 18:25 - Aline (Fenando Nobre): Sim

06/10/15, 18:25 - Aline (Fenando Nobre): :-)

06/10/15, 18:42 - Bosco: :)

06/10/15, 20:39 - Gustavo (Fenando Nobre): Sim

10/10/15, 16:16 - Bosco: Oi pessoal, bom feriado pra vcs o/

10/10/15, 16:17 - Bosco: Tenho uma boa notícia, quarta feira eu vou na escola Fernando nobre falar do jogo que vamos jogar, dar os detalhes e orientar vcs (-)

10/10/15, 19:36 - Aline (Fenando Nobre): Ta

10/10/15, 19:36 - Aline (Fenando Nobre): Pra vc também

10/10/15, $19: 37$ - Eduardo (Fenando Nobre): Bosco

10/10/15, 19:37 - Eduardo (Fenando Nobre): Quarta eu nao vou estar ai

10/10/15, 19:56 - Bosco: $=($

10/10/15, 19:56 - Bosco: Não tem aula quarta?

10/10/15, 19:56 - Eduardo (Fenando Nobre): Tem

10/10/15, 19:56 - Eduardo (Fenando Nobre): Segunda nao

10/10/15, 19:57 - Eduardo (Fenando Nobre): Pq quarta tem passeio

10/10/15, 21:52 - Vinícius (Fenando Nobre): Bosco vc vai no passeio?

10/10/15, 23:32 - Bianca (Fenando Nobre): Quarta tem passeio

10/10/15, 23:33 - Eduardo (Fenando Nobre): Tem

10/10/15, 23:33 - Bianca (Fenando Nobre): Eu sei disso

10/10/15, 23:33 - Eduardo (Fenando Nobre): Ata

10/10/15, 23:34 - Bianca (Fenando Nobre): Quarta tem passeio e é o dia todo

10/10/15, 23:34 - Eduardo (Fenando Nobre): Eu sei disso

11/10/15, 21:27 - Bosco: O passeio é da turma toda? Se for eu vou na outra quarta

11/10/15, $23: 27$ - Bianca (Fenando Nobre): Ss

11/10/15, 23:27 - Bianca (Fenando Nobre): Da escola toda

11/10/15, 23:46 - Bosco: Entendi

13/10/15, 13:54 - Você adicionou Moisés (Fernando Nobre)

13/10/15, 15:45 - José Vinícius (Fenando Nobre) saiu

13/10/15, 14:28 - Moisés (Fernando Nobre): Bosco

13/10/15, 14:28 - Moisés (Fernando Nobre): Quando nós vamos começar a jogar os jogos?

13/10/15, 15:48 - Bosco: Ola, na próxima quarta, essa tem passeio né?

13/10/15, 16:19 - Bianca (Fenando Nobre): Ss

13/10/15, 16:56 - Moisés (Fernando Nobre): Ssim

13/10/15, 16:56 - Moisés (Fernando Nobre): Vc vai?

13/10/15, 17:19 - Bosco: No passeio não posso ir $=1$

13/10/15, 17:20 - Bosco: Onde vai ser o passeio?

13/10/15, 17:20 - Moisés (Fernando Nobre): Mairiporã! Dahora pacas

13/10/15, 17:25 - Bosco: Que legal

13/10/15, 17:25 - Bosco: :)

13/10/15, 17:26 - Bosco: Sempre tem passeio? Vou tentar ir no próximo.

13/10/15, 17:26 - Moisés (Fernando Nobre): Não

13/10/15, 17:26 - Moisés (Fernando Nobre): Esse foi o primeiro

[...]

22/10/15, 06:06 - Bianca (Fenando Nobre): O prof Bosco eu baixei no celular do me pai ta

22/10/15, 06:07 - Gustavo (Fenando Nobre): Eu baixei foi no meu

22/10/15, 06:07 - Bianca (Fenando Nobre): Hm

22/10/15, 10:04 - Bosco: Tudo bem

22/10/15, 10:04 - Bosco: Espero que vcs gostem 
22/10/15, 10:43 - Moisés (Fernando Nobre): Professor procura no Google Play o jogo Clash of clans! Muito maneiro 22/10/15, 11:23 - Bosco: Vou procurar 22/10/15, 18:54 - Gustavo (Fenando Nobre): <Mídia omitida>

22/10/15, 18:58 - Bosco: Isso, por favor conecta sua cidade no facebook pra eu poder acompanhar, posta uma imagem dela no grupo do facebook também?

22/10/15, 19:29 - Gustavo (Fenando Nobre): Como conecta

22/10/15, 19:34 - Bosco: <Mídia omitida>

22/10/15, 20:05 - Gustavo (Fenando Nobre): <Mídia omitida>

22/10/15, 21:04 - Moisés (Fernando Nobre): Já tô no nível 4

22/10/15, 21:05 - Moisés (Fernando Nobre): Eai Bosco já viu o jogo que te mandei?

22/10/15, 21:12 - Bosco: Sim, o clash of clãs?

22/10/15, 21:12 - Moisés (Fernando Nobre): Sim

22/10/15, 21:12 - Bosco: Achei bem legal! A gente pode pensar em usar ele em outra oportunidade

22/10/15, 21:12 - Moisés (Fernando Nobre): Gostou?

22/10/15, 21:12 - Bosco: Sim

22/10/15, 21:12 - Moisés (Fernando Nobre): Ok

22/10/15, 21:13 - Moisés (Fernando Nobre): Quando tivermos outra oportunidade podemos jogar então!

22/10/15, 21:13 - Bosco: :)

22/10/15, 21:14 - Bosco: Vc gostou do sim city?

22/10/15, 21:17 - Bosco: Myke, vc me adicionou no facebook?

22/10/15, 21:20 - Gustavo (Fenando Nobre): Eu to no 5

22/10/15, 21:20 - Bosco: Não consegui te achar $=$ I

22/10/15, 21:21 - Gustavo (Fenando Nobre): Ei tenho ve mas me manda uma mensagem eu visitei sua cidade

22/10/15, 21:21 - Gustavo (Fenando Nobre): Como faz para achar

22/10/15, 21:22 - Bosco: Só apertar no ícone 1 da figura que mandei ainda pouco

22/10/15, 21:22 - Bosco: Aí aparece todos os amigos

22/10/15, 21:22 - Bosco: ainda não apareceu pra mim

22/10/15, 21:22 - Gustavo (Fenando Nobre): Ai eu faço oq

22/10/15, 21:22 - Gustavo (Fenando Nobre): Pramin apareceu vc

22/10/15, 21:28 - Bosco: Vou reiniciar o celular

22/10/15, 21:29 - Moisés (Fernando Nobre): Myke que nível vc está?

22/10/15, 21:37 - Gustavo (Fenando Nobre): No cinco

22/10/15, 21:42 - Moisés (Fernando Nobre): Me visita acabei de subir para o nível 5! Visitei o seu

22/10/15, 21:44 - Bosco: Consigui ver a cidade de vcs

22/10/15, 21:44 - Bosco: Ta crescendo bem! :-)

22/10/15, 21:44 - Bosco: Moisés, vc conseguiu ver a cidade do maky

22/10/15, 21:44 - Bosco: ?

22/10/15, 21:49 - Gustavo (Fenando Nobre): Ei bosco eu ja te visitei. E agora vou visitar o josue

22/10/15, 21:50 - Eduardo (Fenando Nobre): Ai bosco não da pra baixar no meu cel

22/10/15, 21:58 - Moisés (Fernando Nobre): Bosco consigo ver sim a cidade do Myke! Até já visitei

22/10/15, 21:58 - Eduardo (Fenando Nobre): Eae mano creme crack

22/10/15, 21:59 - Moisés (Fernando Nobre): Kkkk Kevyn perdeu, pq o jogo é chave!

22/10/15, 21:59 - Moisés (Fernando Nobre): Eai mano CREME! Kkk

22/10/15, 21:59 - Moisés (Fernando Nobre): 14

22/10/15, 22:00 - Eduardo (Fenando Nobre): Kkkkk

22/10/15, 22:01 - Moisés (Fernando Nobre): Parça vai ir amanhã?

22/10/15, 22:02 - Bosco: Que bom! Depois posta no grupo do facebook imagem da sua cidade?

22/10/15, 22:02 - Eduardo (Fenando Nobre): Vo e vc?

22/10/15, 22:02 - Moisés (Fernando Nobre): Sim

22/10/15, 22:02 - Bosco: Obrigado

23/10/15, 11:32 - Stela Piconez: google play:

https://play.google.com/store/apps/details?id=com.ea.game.simcitymobile_row\&hl=pt_BR

iphone: https://itunes.apple.com/us/app/simcity-buildit/id913292932?mt=8

26/10/15, 10:23 - Bosco: Olá pessoal, tudo bom?

26/10/15, 10:24 - Bosco: Conseguiram jogar? Estão gostando? 
26/10/15, 10:30 - Moisés (Fernando Nobre): Sim professor!

26/10/15, 10:31 - Moisés (Fernando Nobre): Gostei muito, e já estou no nível 7 !

26/10/15, 10:33 - Bosco: Que bom! Quem mais?

26/10/15, 10:45 - Moisés (Fernando Nobre): Que eu saiba só o Mike e o Vinicius!

26/10/15, 17:19 - Bianca (Fenando Nobre): Eu tbm

26/10/15, 17:20 - Bianca (Fenando Nobre): To no nível 5

26/10/15, 17:22 - Bosco: Legal!

26/10/15, 17:22 - Bosco: Ta gostando?

26/10/15, 17:23 - Bianca (Fenando Nobre): Ss

26/10/15, 18:50 - Gustavo (Fenando Nobre): Oi

26/10/15, 18:50 - Gustavo (Fenando Nobre): Gante

26/10/15, 18:54 - Bosco: Oi

26/10/15, 18:58 - Bosco: Não esqueçam de conectar o jogo no facebook pra eu poder acompanhar vcs, por favor :-)

26/10/15, 18:58 - Bosco: <Mídia omitida>

26/10/15, 18:59 - Bosco: Maky e Moisés, vcs podem ajudar seus colegas que não fizeram isso ainda?

26/10/15, 19:28 - Moisés (Fernando Nobre): Oi Pode deixar professor!

27/10/15, 20:02 - Bianca (Fenando Nobre): O professor cono o jogo ta no celular do meu pai adiciona ele no face

28/10/15, 10:43 - Bosco: Ok, passa o link do facebook dele?

28/10/15, 17:29 - Bianca (Fenando Nobre): <Mídia omitida>

28/10/15, 17:29 - Bianca (Fenando Nobre): Givaldo Caetano

29/10/15, 14:56 - Bosco: Adicionei

29/10/15, 15:01 - Bosco: Obrigado

29/10/15, 17:21 - Bianca (Fenando Nobre): :- 울

$[\ldots]$

05/03/16, 11:19 - Daniel (Fernando Nobre): Viih como ta la minha ilha

05/03/16, 11:20 - Daniel (Fernando Nobre): Viu

05/03/16, 11:20 - Rafael (Fernando Nobre): vo ver

05/03/16, 11:20 - Daniel (Fernando Nobre): Ta mo fraca

05/03/16, 11:20 - Rafael (Fernando Nobre): até que ta Boa

05/03/16, 11:21 - Rafael (Fernando Nobre): protege bastante seu Centro e vila

05/03/16, 11:21 - Rafael (Fernando Nobre): Centro de vila

05/03/16, 11:21 - Rafael (Fernando Nobre): e seus depositos

05/03/16, 11:21 - Daniel (Fernando Nobre): Eu sei

05/03/16, 11:21 - Daniel (Fernando Nobre): Ta ruin

05/03/16, 11:22 - Rafael (Fernando Nobre): o Bosco ta deixando os recursos dele muito exposto

05/03/16, 11:23 - Daniel (Fernando Nobre): Hum

05/03/16, 11:23 - Daniel (Fernando Nobre): Viam atacar ele logo logo

05/03/16, 11:23 - Rafael (Fernando Nobre): se eu fosse ele passava cerca em volta do Centro e dos recursos

05/03/16, 11:24 - Daniel (Fernando Nobre): Vam

05/03/16, 11:24 - Rafael (Fernando Nobre): se não ele vai perder tudo

05/03/16, $11: 24$ - Rafael (Fernando Nobre): natan

05/03/16, 11:24 - Rafael (Fernando Nobre): vc tem crédito?

05/03/16, 11:24 - Daniel (Fernando Nobre): Eu sei

05/03/16, 11:24 - Daniel (Fernando Nobre): Co.o eu fiz ne

05/03/16, 11:24 - Rafael (Fernando Nobre): tem?

05/03/16, 11:25 - Daniel (Fernando Nobre): Para ligar

05/03/16, 11:25 - Rafael (Fernando Nobre): se tiver crédito segunda eu faço toda sua defesa

05/03/16, 11:25 - Daniel (Fernando Nobre): Nn

05/03/16, 11:25 - Rafael (Fernando Nobre): vish

05/03/16, 11:25 - Moisés (Fernando Nobre): Fala ae seus puto

05/03/16, 11:25 - Rafael (Fernando Nobre): será que alguém sabe a senha do Wi-Fi da escola

05/03/16, 11:26 - Daniel (Fernando Nobre): depois eu te

05/03/16, 11:26 - Daniel (Fernando Nobre): Asso minha como conta

05/03/16, 11:26 - Você adicionou Vinícius(fernando Nobre)

05/03/16, 11:26 - Rafael (Fernando Nobre): oks 
05/03/16, 11:26 - Rafael (Fernando Nobre): Bosco 05/03/16, 11:27 - Rafael (Fernando Nobre): vc tem que passar cerca em volta do seu Centro de Vila e recursos

05/03/16, 11:27 - Daniel (Fernando Nobre): Vo jogar

05/03/16, 11:27 - Moisés (Fernando Nobre): Agora sim em Bosco

05/03/16, 11:27 - Rafael (Fernando Nobre): blz

05/03/16, 11:27 - Rafael (Fernando Nobre): se não vai perder td

05/03/16, 11:27 - Bosco: Blz, vou fazer assim que acabar a reforma no centro, to sem construtor

05/03/16, 11:27 - Bosco: Valeu

05/03/16, 11:27 - Rafael (Fernando Nobre): oks

05/03/16, 11:28 - Rafael (Fernando Nobre): nads

05/03/16, 11:28 - Rafael (Fernando Nobre): só to esperando terminar minhas tropas pra eu fazer uns atack

05/03/16, 11:28 - Rafael (Fernando Nobre): alguém aqui ja jogou king of thievs?

05/03/16, 11:29 - Moisés (Fernando Nobre): Acho que não

05/03/16, 11:30 - Rafael (Fernando Nobre): kkk e da hora tbm

05/03/16, 11:30 - Rafael (Fernando Nobre): o objetivo e se tornar o rei dos ladrões

05/03/16, 11:30 - Moisés (Fernando Nobre): hum

05/03/16, 11:31 - Rafael (Fernando Nobre): tem ligas tbm de madeira,bronze,prata,Ouro e God

05/03/16, 11:31 - Rafael (Fernando Nobre): (Deus)

05/03/16, 11:31 - Moisés (Fernando Nobre): eu yo na prata eu scho

05/03/16, 11:31 - Moisés (Fernando Nobre): acho

05/03/16, 11:31 - Rafael (Fernando Nobre): eu to na prata |||

05/03/16, 11:31 - Rafael (Fernando Nobre): acaba daqui 1Dia

05/03/16, 11:31 - Moisés (Fernando Nobre): eu tb

05/03/16, 11:32 - Rafael (Fernando Nobre): to no rank 820

05/03/16, 11:32 - Rafael (Fernando Nobre): hj Inda pego pelo menos rank 4 ou três

05/03/16, 11:32 - Rafael (Fernando Nobre): ainda*

05/03/16, $11: 32$ - Rafael (Fernando Nobre): vo la jogar

05/03/16, 11:34 - Bosco: Só queria pedir um favor pra vcs, usem esse grupo, e evitem usar o chat do clã do jogo, pq fica mais fácil pra eu acompanar o que vcs falam daqui desse grupo ok?

05/03/16, 11:34 - Bosco: Obrigado! Está sendo muito divertido jogar com vocês!!!

05/03/16, 11:34 - Rafael (Fernando Nobre): okะ

05/03/16, 11:34 - Bosco: :)

05/03/16, 11:34 - Moisés (Fernando Nobre): ok

05/03/16, 11:34 - Rafael (Fernando Nobre):

05/03/16, 11:35 - Rafael (Fernando Nobre): Minha arqueiro passa pro nv 3 em 4 Hrs

05/03/16, 11:35 - Moisés (Fernando Nobre): Está mesmo

05/03/16, 11:35 - Moisés (Fernando Nobre): Nossa

05/03/16, 11:35 - Rafael (Fernando Nobre): £a£ Bem loko

05/03/16, 11:35 - Moisés (Fernando Nobre): Só 4 hrs

05/03/16, 11:35 - Rafael (Fernando Nobre): não menti:i)

05/03/16, 11:36 - Rafael (Fernando Nobre): falta umas $12 \mathrm{Hrs}$

05/03/16, 11:36 - Rafael (Fernando Nobre): faz uns dois dias que ele ta la upando

05/03/16, 11:36 - Rafael (Fernando Nobre): quase dois dias

05/03/16, 11:36 - Rafael (Fernando Nobre): mas demora sois dias

05/03/16, 11:36 - Rafael (Fernando Nobre): dois?

05/03/16, 11:36 - Rafael (Fernando Nobre): dois*

05/03/16, 11:37 - Moisés (Fernando Nobre): hum

05/03/16, 11:37 - Rafael (Fernando Nobre): demora pra caranba

05/03/16, 11:39 - Rafael (Fernando Nobre): ja coletará a Torre do tesouro?

05/03/16, 11:41 - Rafael (Fernando Nobre): estou passando meu depósito de elixir pro nv 7 e tenho um de nv 8

05/03/16, 11:50 - Vinícius(fernando Nobre): Qual é o nome do cla

05/03/16, 11:50 - Rafael (Fernando Nobre): Os Breakmens

05/03/16, 11:51 - Rafael (Fernando Nobre): ta com um símbolo branco e prot

05/03/16, 11:51 - Rafael (Fernando Nobre): preto

05/03/16, 11:51 - Vinícius(fernando Nobre): Os Breakmens 
06/03/16, 11:30 - Luiza (Fenando Nobre): Eeentaaaao neee

06/03/16, 11:30 - Moisés (Fernando Nobre): Oi Vi

06/03/16, 11:30 - Moisés (Fernando Nobre): Vc está jogando esse jogo?

06/03/16, 11:31 - Luiza (Fenando Nobre): Não

06/03/16, 11:31 - Vinícius(fernando Nobre): IAE

06/03/16, 11:31 - Moisés (Fernando Nobre): Hum

06/03/16, 11:31 - Luiza (Fenando Nobre): Não posso baixar jogos no celular

06/03/16, 11:31 - Moisés (Fernando Nobre): Eae Alambida

06/03/16, 11:31 - Vinícius(fernando Nobre): O Nando e o meu primo vai chega no cla

06/03/16, 11:31 - Luiza (Fenando Nobre): Esta travando muito

06/03/16, 11:31 - Daniel (Fernando Nobre): Ele levou tudo

06/03/16, 11:32 - Vinícius(fernando Nobre): Espera acabar a guerra deles

06/03/16, 11:32 - Daniel (Fernando Nobre): Porq

06/03/16, 11:33 - Daniel (Fernando Nobre): Já acabou Ele já levou tudo vou fazer Vingança contra 06/03/16, 11:33 - Moisés (Fernando Nobre): Ok

06/03/16, 11:34 - Bosco: Vitória, vou até a escola segunda, posso tentar ajeitar seu celular se vc quiser

06/03/16, 11:35 - Luiza (Fenando Nobre): Ok

06/03/16, 11:35 - Moisés (Fernando Nobre): Eu fiz a conta pra ele! Ele fica de frescura

06/03/16, 11:37 - Vinícius(fernando Nobre): O pq n aceitaram o meu primo

06/03/16, 11:37 - Vinícius(fernando Nobre): ?

06/03/16, 11:37 - Vinícius(fernando Nobre): O pq n aceitaram o meu primo

06/03/16, $11: 37$ - Vinícius(fernando Nobre): ?

06/03/16, 11:37 - Rafael (Fernando Nobre): o breninj

06/03/16, 11:37 - Moisés (Fernando Nobre): Perai Vinícius

$[\ldots]$ 


\section{Anexo E}

\section{Moodle - Grupo Alpha}

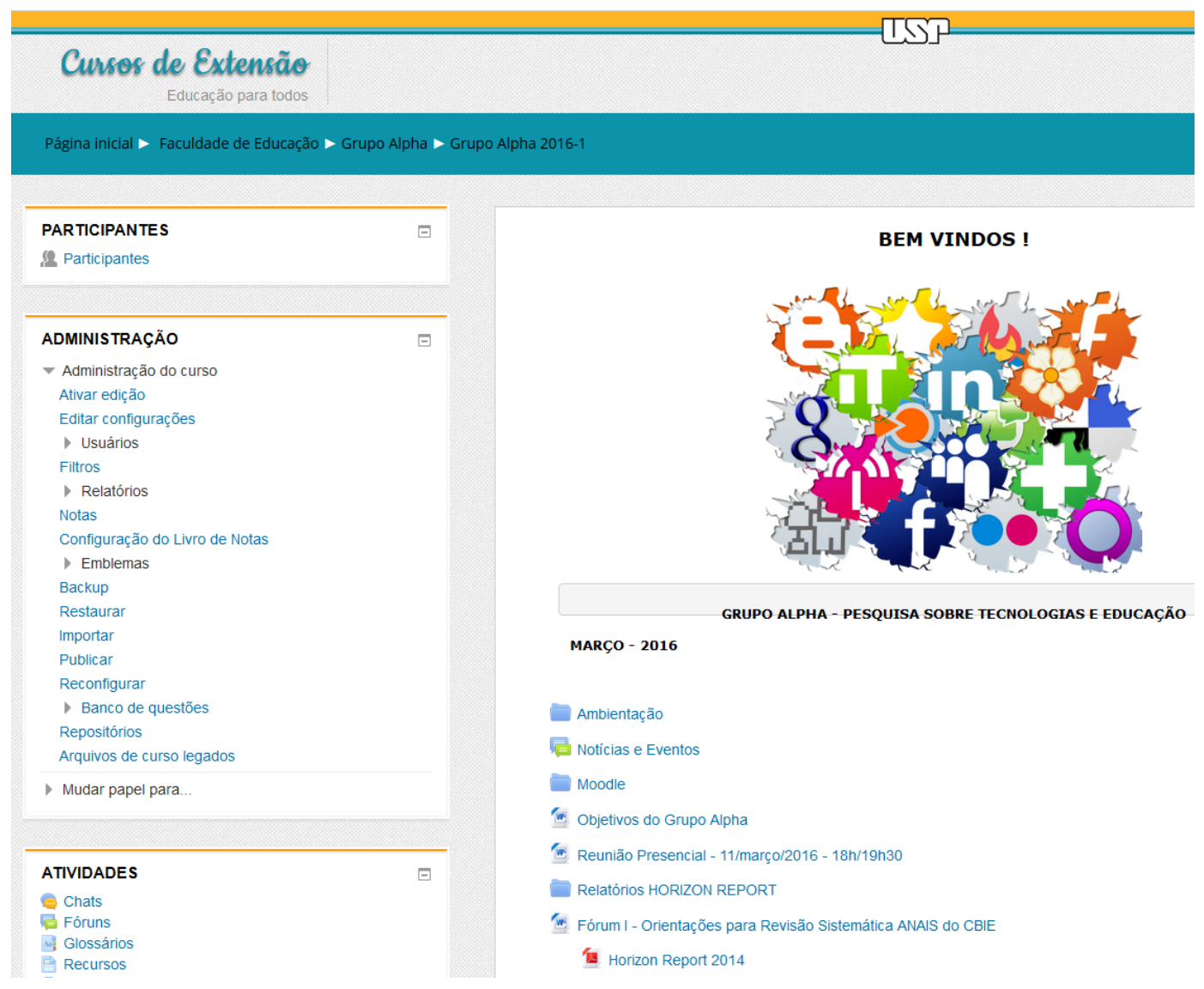

Figura E.1: Documento digitalizado 


\section{SETEMBRO - 2016}

\section{!}

Reunião presencial - 02/setembro/2016 - 18h30 às 20h

2. VideoConf. 30/setembro/2016 - 18h30 às 20h - Hanghout

A4l Elaborar Glossário

a The Idea of Openness

- Nova Taxionomia Digital

Livros Eletrônicos das Conferências Mundiais de Mapas Conceituais

牦 e-Book - Mobile Media Learning

e-Book Teaching in a Digital Age

Dudoliteracy: Defining, Understand and Supporting Games Education

- e- Book Learning, Education and Games. Volume One: Curricular and Design Considerations

- e-BookDigital Thinking and Mobile Teaching Communicating, Collaborating \& Constructing in an Access Age

e-Book New technologies, new pedagogies: Mobile learning in higher education

Figura E.2: Documento digitalizado 
Anexo F

Matriz Curricular 


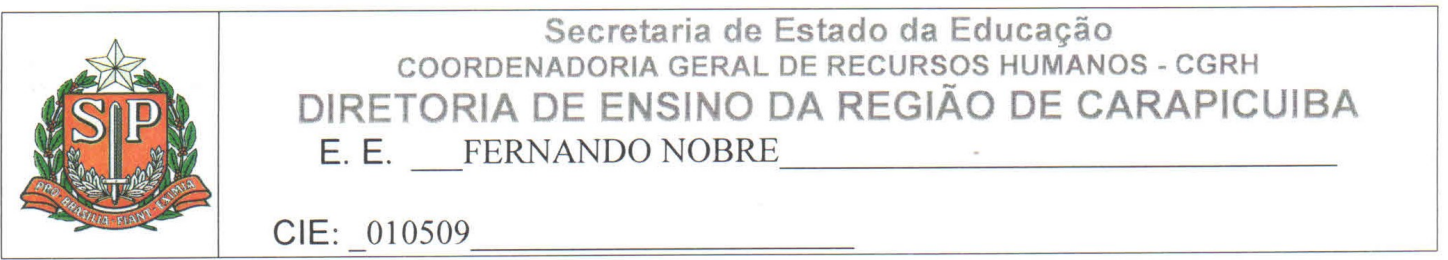

MATRIZ CURRICULAR - ESCOLA DE TEMPO INTEGRAL - 2015

Fundamento Legal: Lei Federal 9394/96, Resolução SE 85 de 19/12/2013

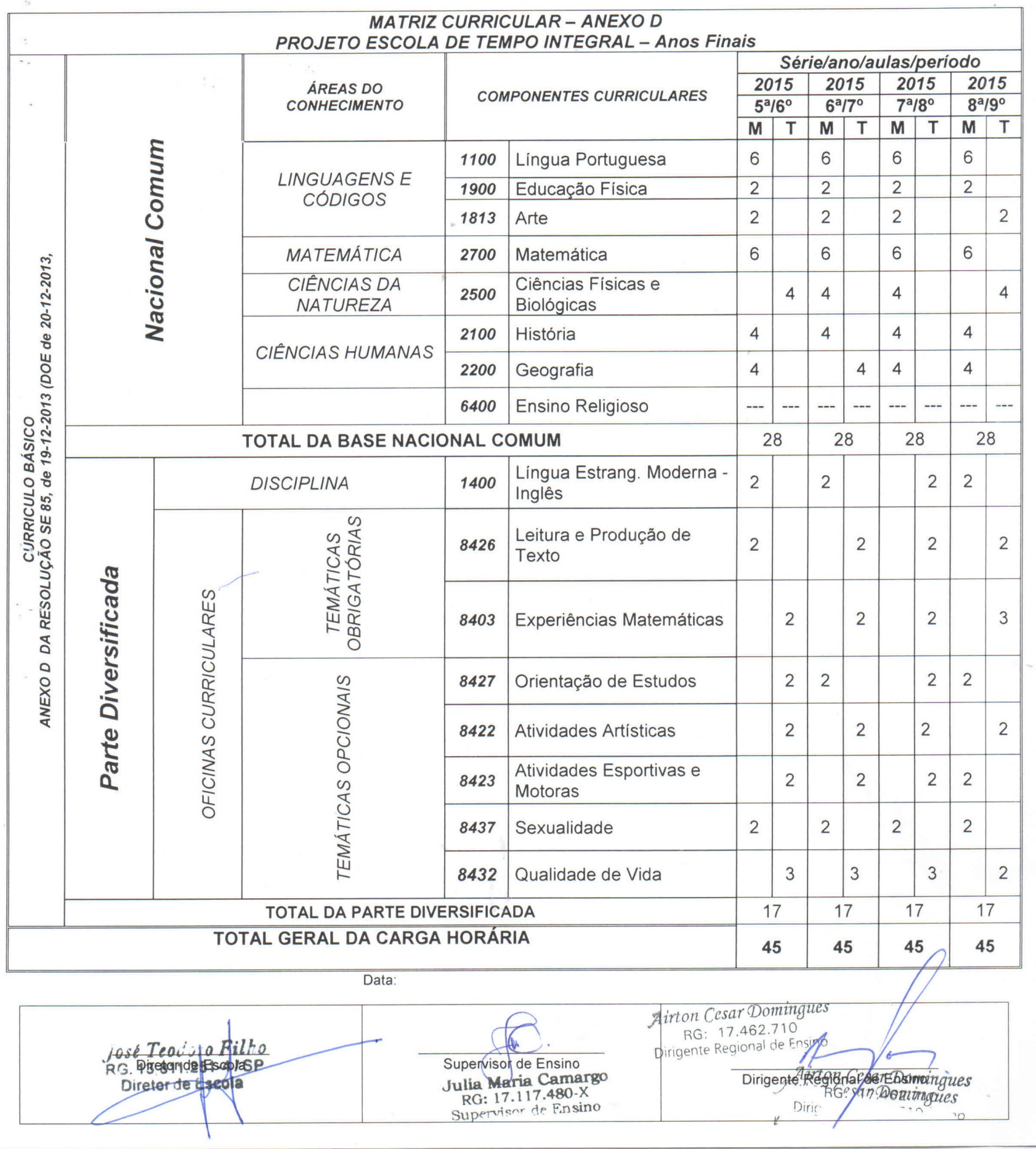

Figura F.1: Documento digitalizado 


\title{
Referências Bibliográficas
}

\author{
Almeida e Valente (2012) Maria Elizabeth Bianconcini de Almeida e José Armando Valente. \\ Integração currículo e tecnologias e a produção de narrativas digitais. Currículo sem fronteiras, \\ 12(3):57-82. Citado na pág. 12
}

Altrichter et al. (2013) Herbert Altrichter, Allan Feldman, Peter Posch e Bridget Somekh. Teachers investigate their work: An introduction to action research across the professions. Routledge. Citado na pág. 19

Antônio (2014) Wagner Junior Antônio. Jogos digitais e a mediação do conhecimento na perspectiva da psicologia histórico-cultural. Dissertação de Mestrado, Universidade de São Paulo, Faculdade de Educação, São Paulo. Citado na pág. 35, 38

Atari (2012) Atari. About atari, sa @ONLINE, Março 2012. URL https://www.atari.com/ corporate/about-atari-sa. Citado na pág. 1

Avraamidou et al. (2015a) Antri Avraamidou, John Monaghan e Aisha Walker. Digital Games and Mathematics Learning: Potential, Promises and Pitfalls, chapter Mathematics and NonSchool Gameplay, páginas 11-34. Springer Netherlands, Dordrecht. ISBN 978-94-017-9517-3. doi: 10.1007/978-94-017-9517-3_2. URL http://dx.doi.org/10.1007/978-94-017-9517-3_2. Citado na pág. 10

Avraamidou et al. (2015b) Antri Avraamidou, John Monaghan e Aisha Walker. Mathematics and non-school gameplay. Em Digital Games and Mathematics Learning, páginas 11-34. Springer. Citado na pág. 42,43

Barbier (2007) René Barbier. A pesquisa-ação, volume 3. Líber Livro. Citado na pág. 15, 16

Battaiola (2000) André L Battaiola. Jogos por computador-histórico, relevância tecnológica e mercadológica, tendências e técnicas de implementação. Anais da XIX Jornada de Atualização em Informática, SBC, 2:83-122. Citado na pág. 6

Beavis (2015) Catherine Beavis. Multimodal literacy, digital games and curriculum. Em Digital Games and Mathematics Learning, páginas 109-122. Springer. Citado na pág. 42, 43

Beavis et al. (2015) Catherine Beavis, Sandy Muspratt e Roberta Thompson. 'computer games can get your brain working': student experience and perceptions of digital games in the classroom. Learning, media and technology, 40(1):21-42. Citado na pág. 42, 43

Bing (2013) Joseph Pang Kok Bing. Enhancing narrative writing skills through action-adventure video games. Journal of Education and Practice, 4(15):36-42. Citado na pág. 41, 42

Boyd e Ellison (2008) Danah Boyd e Nicole Ellison. Getting a job via career-oriented social networking sites: The weakness of tie. 49th Annual Hawaii International Conference on System Sciences. Kauai, Hawaii, 13:210?230. doi: 10.1111/j.1083-6101.2007.00393.x. Citado na pág. 9

Braghirolli (2014) Lynceo Falavigna Braghirolli. Aprendizagem por jogo computacional na engenharia de produção. Tese de Doutorado, Universidade Federal do Rio Grande do Sul. Escola de 
Engenharia. Programa de Pós-Graduação em Engenharia de Produção, Rio Grande do Sul. Citado na pág. 35,37

Brom et al. (2011) Cyril Brom, Michal Preuss e Daniel Klement. Are educational computer microgames engaging and effective for knowledge acquisition at high-schools? a quasi-experimental study. Computers \&̇ Education, 57(3):1971-1988. Citado na pág. 40

Buchinger (2014) Diego Buchinger. Sherlock dengue 8: the neighborhood - um jogo sério colaborativo-competitivo para combate à dengue. Dissertação de Mestrado, Universidade do Estado de Santa Catarina, Departamento de Computação, Programa de Mestrado em Computação Aplicada, Santa Catarina. Citado na pág. 35, 38

Buettner (2016) R. Buettner. Social network sites: Definition, history, and scholarship. Journal of Computer-Mediated Communication 13, 49. doi: 10.13140/RG.2.1.3249.2241. Citado na pág. 9

Butler (2011) Margaret Butler. Android: Changing the mobile landscape. IEEE Pervasive Computing, 10(1):4-7. Citado na pág. 2

Campos e Macedo (2011) MCRM Campos e L de Macedo. Desenvolvimento da função mediadora do professor em oficinas de jogos. Psicologia Escolar e Educacional, 15(2):211-219. Citado na pág. 50

Castells (1999) Manuel Castells. A sociedade em rede-a era da informação: economia, sociedade e cultura. São Paulo: Paz e Terra,, 1. Citado na pág. xvii

Checa-Romero (2015) Mirian Checa-Romero. Developing skills in digital contexts video games and films as learning tools at primary school. Games and Culture, página 1555412015569248. Citado na pág. 42, 44

Chizzotti (2006) Antonio Chizzotti. Pesquisa qualitativa em ciências humanas e sociais. Vozes. Citado na pág. 15

Clark et al. (2016) Douglas B Clark, Emily E Tanner-Smith e Stephen S Killingsworth. Digital games, design, and learning: A systematic review and meta-analysis. Review of educational research, 86(1):79-122. Citado na pág. 40

Câmara (2014) Bárbara Bezerra Arruda Câmara. Motivação e games: o uso do jogo angry birds com estudantes para o ensino de física. Dissertação de Mestrado, Universidade Federal de Pernambuco, Programa de Pós-Graduação em Psicologia Cognitiva, Pernambuco. Citado na pág. 35,38

Cohen et al. (2013) Louis Cohen, Lawrence Manion e Keith Morrison. Research methods in education. Citado na pág. 19

Cook e Bell (1962) RM Cook e RC Bell. Board and Table Games from Many Civilisations, volume 1. Courier Corporation. Citado na pág. xvii

Da Ros (2002) Silvia Zanatta Da Ros. Pedagogia e mediação em Reuven Feuerstein. Plexus Editora. Citado na pág. $47,48,49$

De Mul (2005) Jos De Mul. The game of life. narrative and ludic identity formation in computer games. In: J. Goldstein and J. Raessens,Handbook of Computer Games Studies., páginas 251-266. Citado na pág. xvii

Denzin e Lincoln (1994) Norman K Denzin e Yvonna S Lincoln. Handbook of qualitative research. Sage publications, inc. Citado na pág. 18 
Dietz e Leigh (2001) Paul Dietz e Darren Leigh. Diamondtouch: a multi-user touch technology. Em Proceedings of the 14th annual ACM symposium on User interface software and technology, páginas 219-226. ACM. Citado na pág. 40

Dubost (1987) Jean Dubost. Sur les sources techniques de l'intervention psychosociologique et quelques questions actuelles. Connexions, 49:140. Citado na pág. 15

Erhel e Jamet (2013) S Erhel e E Jamet. Digital game-based learning: Impact of instructions and feedback on motivation and learning effectiveness. Computers $\mathscr{E}$ Education, 67:156-167. Citado na pág. 8

Feuerstein et al. (2014) Reuven Feuerstein, Refael S Feuerstein e Louis H FALIK. Além da inteligência: aprendizagem mediada e a capacidade de mudança do cérebro. Tradução de Aline Kaehler. Petrópolis, RJ: Vozes. Citado na pág. xiii, xv, xvi, 49, 50, 51, 55, 80

Feuerstein (1970) Rubin Feuerstein. Les différences de fonctionnement cognitif dans des groupes socio-ethniques différents: leur nature, leur étiologie et les pronostics de modifiabilité. Tese de Doutorado, Sorbonne, Paris. Citado na pág. 47

Fonseca (2014) Vitor da Fonseca. Aprender a reaprender: A educabilidade cognitiva do século xxi. PerspectivasOnLine 2007-2010,3(11). Citado na pág. 50

Forehand (2010) Mary Forehand. Bloom?s taxonomy. Emerging perspectives on learning, teaching, and technology, 41:47. Citado na pág. 3

Freire (2006) Paulo Freire. Pedagogia da Autonomia: saberes necesarios para la práctica educativa. Siglo XXI. Citado na pág. 33

Gee (2003) James Paul Gee. What video games have to teach us about learning and literacy. Computers in Entertainment (CIE), 1(1):20-20. Citado na pág. 3, 4

Gomes (2001) Cristiano Mauro Assis Gomes. Em busca de um modelo psico-educativo para a avaliação de softwares educacionais. Florianópolis, UFSC, 2001, 138 f. Tese de Doutorado, Programa de Pós-Graduação em Engenharia de Produção, Universidade Federal de Santa Catarina. Citado na pág. 50

Greenfield (1985) P. Marks Greenfield. El niño y los medios de communicatión. ISBN 9788471123022. Citado na pág. xvii

Hagenuk (2012) Hagenuk. Hagenuk history @ONLINE, Março 2012. URL http://www. hagenuk-germany.de/en/history.htmla. Citado na pág. 2

Hugon e Seibel (1988) Marie-Anne Hugon e Claude Seibel. Recherches impliquées, recherches action: le cas de l'éducation: synthèse des contributions et des débats du Colloque organisé par l'Institut National de Recherche Pédagogique, Paris, les 22, 23et 24 octobre 1986. De Boeck. Citado na pág. 15

Huizinga (1956) Johan Huizinga. Homo Ludens Vom Ursprung der Kultur Im Spiel. Rowohlt, first ed. Citado na pág. xvii, 1

Hwang e Su (2012) Wu-Yuin Hwang e Jia-Han Su. The study of surface computer supported cooperative work and its design, efficiency, and challenges. Interactive Learning Environments, 20(2):177-198. Citado na pág. 40

IBGE (2000) IBGE. Censo demográfico 2000 e pesquisa de orçamentos familiares - pof 2002/2003, Março 2000. URL http://cod.ibge.gov.br/41X8. Citado na pág. 20

IBGE (2010) IBGE. Ccenso demográfico 2010, Março 2010. URL http://cod.ibge.gov.br/CP1U. Citado na pág. 19 
Ignácio (2013) Andréia Christina Ignácio. O rpg eletrônico no ensino de química: uma atividade lúdica aplicada ao conhecimento de tabela periódica. Dissertação de Mestrado, Universidade Tecnológica Federal do Paraná,Programas de Pós-Graduação Stricto-Sensu, Paraná. Citado na pág. 35,37

Jappur (2014) Rafael Feyh Jappur. Modelo conceitual para criação, aplicação e avaliação de jogos educativos digitais. Tese de Doutorado, Universidade Federal de Santa Catarina, Centro Tecnológico, Programa de Pós-Graduação em Engenharia e Gestão do Conhecimento, Santa Catarina. Citado na pág. 33, 35

Johnson (2006) Steven Johnson. Everything bad is good for you: How today's popular culture is actually making us smarter. Penguin. Citado na pág. 4

Kahne (2016) Joseph Kahne. History of games \& learning, November 2016. URL http://www. instituteofplay.org/about/context/history-of-games-learning. Citado na pág. xviii

Kent (2010) Steven Kent. The Ultimate History of Video Games: from Pong to Pokemon and beyond... the story behind the craze that touched our li ves and changed the world. Three Rivers Press. Citado na pág. 1, 2

Kitzinger (1995) Jenny Kitzinger. Qualitative research. introducing focus groups. BMJ: British medical journal, 311(7000):299. Citado na pág. 17

Klein et al. (2000) Pnina S Klein, Ofra Nir-Gal e Efraim Darom. The use of computers in kindergarten, with or without adult mediation; effects on children's cognitive performance and behavior. Computers in human behavior, 16(6):591-608. Citado na pág. 50

Lave e Wenger (1991) Jean Lave e Etienne Wenger. Situated learning: Legitimate peripheral participation. Cambridge university press. Citado na pág. 40

Lealdino Filho (2014) Pedro Lealdino Filho. Jogo digital educativo para o ensino de matemática. Dissertação de Mestrado, Universidade Tecnológica Federal do Paraná, Programas de Pós-Graduação Stricto-Sensu (Mestrados e Doutorados), Paraná. Citado na pág. 34, 35

Lessard-Hébert (1991) Michelle Lessard-Hébert. Recherche action en milieu éducatif. Agence d'ARC. Citado na pág. 15

Lester et al. (2014) James C Lester, Hiller A Spires, John L Nietfeld, James Minogue, Bradford W Mott e Eleni V Lobene. Designing game-based learning environments for elementary science education: A narrative-centered learning perspective. Information Sciences, 264:4-18. Citado na pág. 8

Lima et al. (2007) Telma Cristiane Sassode Lima, Regina Célia Tamaso Mioto e Keli Regina Dal Prá. A documentação no cotidiano da intervenção dos assistentes sociais: algumas considerações acerca do diário de campo. Revista Virtual Textos $\& 3$ Contextos, 7. Citado na pág. 18

Lourenço (2012) Carlos Eduardo Lourenço. O "estado da arte"da produção de teses e dissertações sobre games - entendidos como forma de comunicação - no banco de dados capes realizadas entre 1987 e 2010. Disertação de Mestrado, USP, 1. Citado na pág. xvii, xviii, 33

Marques (2014) Leonardo Brandão Marques. Estudo de inserção de jogos computadorizados como recurso complementar ao ensino de leitura. Tese de Doutorado, Universidade Federal de São Carlos, Programa de Pós-graduação em Psicologia Câmpus São Carlos. Citado na pág. 35, 36

Marshall (1977) Thomas H. Marshall. Class, citizenship and social development: Essays by TH Marshall. With an introduction by Seymour Martin Lipset. University of Chicago Press. Citado na pág. xviii 
Maziviero (2014) Hélio Fernando Gomes Maziviero. Jogos digitais no ensino de matemática: o desenvolvimento de um instrumento de apoio ao diagnóstico das concepções dos alunos sobre diferentes representações dos números. Dissertação de Mestrado, Universidade Estadual Paulista, Programa de Pós-Graduação em Educação para a Ciência, São Paulo. Citado na pág. 35, 37

MEC (2014) MEC. Relatório educação para todos no brasil 2000-2015, Junho 2014. URL http://portal.mec.gov.br/index.php?option=com_docman\&view=download\&alias= 15774-ept-relatorio-06062014\&category_slug $=$ junho-2014-pdf\&Itemid=30192. Citado na pág. xviii

Menezes (2013) Janaína Menezes. Jogos sociais digitais como ambiente de aprendizagem da língua inglesa. Dissertação de Mestrado. Citado na pág. 34, 35

Nokia (2005) Nokia. Snake creator receives special recognition from mobile entertainment forum @ONLINE, 2005. URL http://company.nokia.com/en/news/press-releases/2005/06/16/ snake-creator-receives-special-recognition-from-mobile-entertainment-forum. Citado na pág. 2

Noyons et al. (2011) M Noyons, D MacQueen, B Johnstone, E Robertson, T Palm e JC Point. Mobile games architecture-state of the art of the european mobile games industry. Retrieved July, 10:2013. Citado na pág. 2

O'Donoghue e Punch (2003) Tom O'Donoghue e Keith Punch. Qualitative educational research in action: Doing and reflecting. Routledge. Citado na pág. 19

Orion e Hofstein (1994) Nir Orion e Avi Hofstein. Factors that influence learning during a scientific field trip in a natural environment. Journal of research in science teaching, 31(10): 1097-1120. Citado na pág. 41

Pachler (2009) Norbert Pachler. Research methods in mobile and informal learning: Some issues. Citado na pág. 40, 41

Pereira et al. (2016a) Adalberto Bosco Pereira, Stela Piconez e Flávio Soares Corrêa Zimmer. Mathematics experiences: Pedagogical implications with the use of digital games, m-learning and social networks. Em Learning Objects and Technology (LACLO), Latin American Conference on, páginas 1-9. IEEE. Citado na pág. 42, 44

Pereira et al. (2016b) Adalberto Bosco Pereira, Stela Piconez, Josete Zimmer e Flávio Soares Corrêa da Silva. Jogos digitais no desenvolvimento de conceitos matemáticos sob perspectiva byod e abordagem m-learning na escola pública. Em Anais do Workshop de Informática na Escola, volume 22, página 71. Citado na pág. 42,44

Pereira e Monteiro (2012) Adalberto Bosco Castro Pereira e Dionne Cavalcante Monteiro. Um sistema fuzzy para geração de tarefas de ensino de leitura e escrita em um jogo digital. Disertação (Mestrado em Ciências da Computação), UFPA PA. Citado na pág. 6

Piccione (1980) Peter A Piccione. In search of the meaning of Senet. Archaeological Institute of America. Citado na pág. xvii

Pinto (2014) Marcos Roberto Pinto. Educação com entretenimento: um experimento com simcity ${ }^{\circledR}$ para curtir e aprender contabilidade governamental. Tese de Doutorado, Universidade de São Paulo, Faculdade de Economia, Administração e Contabilidade, Programa de Pós GraduaçãoSão Paulo. Citado na pág. 35, 39

Prensky (2007) Marc Prensky. Changing paradigms. Educational Technology, páginas 1-3. Citado na pág. 4

Razak e Connolly (2013) Aishah Abdul Razak e Thomas M Connolly. Using games as a context for interdisciplinary learning: A case study at a scottish primary school. Em Global Engineering Education Conference (EDUCON), 2013 IEEE, páginas 1084-1092. IEEE. Citado na pág. 41, 42 
Reuven (1980) Feuerstein Reuven. Instrumental enrichment; an intervention program for cognitive modifiability. UNIVERSITY PARK PRESS. Citado na pág. 50

Rocha et al. (2010) M.P. Rocha, P.D. Costa, P.S. Prampero e V. Aparecida. Introdução aos jogos digitais @ONLINE, Março 2010. Citado na pág. 3

Salami e Sarmento (2011) Marcelo Salami e Dirlécopyrightia Fanfa Sarmento. Interfaces conceituais entre os pressupostos de l. s. vygotsky e de r. feuerstein e suas implicações para o fazer psicopedagógico no âmbito escolar. Revista Psicopedagogia, 28:76 - 84. ISSN 0103-8486. URL http:// pepsic.bvsalud.org/scielo.php?script $=$ sci_arttext\&pid $=$ S0103-84862011000100008\&nrm $=$ iso. Citado na pág. 48

Santos (2014) Bergston Luan Santos. Interpretando "mundos": jogos digitais \& aprendizagem histórica. Dissertação de Mestrado, Universidade Federal de Uberlândia, Faculdade de Educação, Programa de Pós-Graduação em Educação, Minas Gerais. Citado na pág. 35, 39

Santos (2015) Ivson Henrique Bezerra dos Santos. Qualidade dos jogos que influenciam positivamente o processo de aprendizado: uma análise crítica. Dissertação de Mestrado, Universidade Federal de Pernambuco, Programa de Pós Graduação em Ciência da Computação, Pernambuco. Citado na pág. 35,40

Söbke et al. (2013) Heinrich Söbke, Thomas Bröker e Oliver Kornadt. Using the master copyadding educational content to commercial video games. Em European Conference on Games Based Learning, página 521. Academic Conferences International Limited. Citado na pág. 42, 43

Schell (2011) Jesse Schell. A arte de game design: o livro original. Campus. São Paulo. ISBN: 8535241981. Citado na pág. 2

Schuytema (2008) Paul Schuytema. Design de Games: Uma abordagem prática. Cengage Learning. Citado na pág. 2,3

Shahriarpour et al. (2014) Nahid Shahriarpour et al. On the effect of playing digital games on iranian intermediate efl learners? motivation toward learning english vocabularies. Procedia-Social and Behavioral Sciences, 98:1738-1743. Citado na pág. 42

Sharples et al. (2002) Mike Sharples, Dan Corlett e Oliver Westmancott. The design and implementation of a mobile learning resource. Personal and Ubiquitous computing, 6(3):220-234. Citado na pág. 41

Shrock (2016) K Shrock. Samr and blooms. Kathy Schrock?s Guide to Everything SAMR. Citado na pág. xiii, 3

Silva (2015) Aictyr Lomonte da Silva. Exclusão do professor: causas, conseqüências e ações para superação. Citado na pág. xviii

Silva (2014) Américo Junior Nunes da Silva. Formação lúdica do futuro professor de matemática por meio do laboratório de ensino. Dissertação de Mestrado, Universidade Federal de Brasília, Programa de Pós-graduação, Mestrado em Educação, Brasília. Citado na pág. 35, 36

Soares (2013) Wilka Catarina da Silva Soares. A aprendizagem de inglês mediada por jogos eletrônicos do tipo mmorpg. Dissertação de Mestrado, Universidade Federal do Rio Grande do Norte, Programa de Pós-Graduação em Estudos da Linguagem, Rio Grande do Norte. Citado na pág. 35

Stokrocki (2013) Mary Stokrocki. Youth-created avatars, sites, and role-playing in the virtual game the sims 2. Visual Arts Research, 39(2):28-41. Citado na pág. 42, 44 
Sun et al. (2015) Chuen-Tsai Sun, Shu-Hao Ye e Yu-Ju Wang. Effects of commercial video games on cognitive elaboration of physical concepts. Computers $\mathscr{E}$ Education, 88:169-181. Citado na pág. 42,44

Sundqvist (2013) Pia Sundqvist. Categorization of digital games in english language learning studies: Introducing the ssi model. Em 2013 EUROCALL Conference, página 231. Citado na pág. 41,42

Tabuti e Nakamura (2015) Lucy Mari Tabuti e Ricardo Nakamura. Métodos para o desenvolvimento de jogos digitais de lógica: Uma revisão sistemática. Em Brazilian Symposium on Computers in Education (Simpósio Brasileiro de Informática na Educação-SBIE), volume 26, página 41. Citado na pág. 40

Tan e So (2015) Esther Tan e Hyo-Jeong So. Rethinking the impact of activity design on a mobile learning trail: The missing dimension of the physical affordances. IEEE Transactions on Learning Technologies, 8(1):98-110. Citado na pág. 41

Tavares et al. (2006) Rogério Junior Correia Tavares et al. Videogames: brinquedos do póshumano. Tese de Doutorado , PUC SP, 1. Citado na pág. 1

Trad (2009) Leny Alves Bomfim Trad. Grupos focais: conceitos, procedimentos e reflexões baseadas em experiências com o uso da técnica em pesquisas de saúde. Citado na pág. 17

Trois (2013) Sonia Trois. Proposta de heurísticas para adaptação de conteúdo instrucional a games educativos. Dissertação de Mestrado, Universidade Federal do Rio Grande do Sul. Escola de Engenharia. Faculdade de Arquitetura. Programa de Pós-Graduação em Design, Rio grande do Sul. Citado na pág. 34, 35

UNESCO (2014) UNESCO. Diretrizes de políticas para a aprendizagem móvel, 2014. Citado na pág. 9,33

Uusi-Mäkelä (2015) Mikael Uusi-Mäkelä. Learning english in minecraft: a case study on language competences and classroom practices. Dissertação de Mestrado, Tampereen yliopisto, Englantilainen filologia - English Philology. Citado na pág. 42, 43

Valente e Almeida (2014) José Armando Valente e Maria Elizabeth Bianconcini de Almeida. Narrativas digitais e o estudo de contextos de aprendizagem. Revista EmRede, 1(1):32-50. Citado na pág. 13

Víctora et al. (2000) Ceres Gomes Víctora, Daniela Riva Knauth e Maria de Nazareth Agra Hassen. Pesquisa Qualitativa em Saúde: introdução ao tema. Tomo Editorial. Citado na pág. 18

Vicente et al. (2005) Victor Emmanuel José de Sousa Vicente et al. Análise das estruturas interativas em jogos multiplayer: Caso counter-strike. Disertação (Mestrado em Comunicação e Semiótica), PUC SP, 1. Citado na pág. 1

Vieira e Corrêa da Silva (2014) Luiz C Vieira e Flávio S Corrêa da Silva. Understanding fun. Videojogos, At Barcelos, Portugal. Citado na pág. xvii

Vigotsky (1989) Lev Semenovich Vigotsky. A Formação Social da Mente. Martins Fontes. Citado na pág. 50

Vygotsky (1967) Lev S Vygotsky. Play and its role in the mental development of the child. Soviet psychology, 5(3):6-18. Citado na pág. 50, 55

Wilson (2004) Andrew D Wilson. Touchlight: an imaging touch screen and display for gesturebased interaction. Em Proceedings of the 6th international conference on Multimodal interfaces, páginas 69-76. ACM. Citado na pág. 40 
Yoon e Kim (2015) Du-Mim Yoon e Kyung-Joong Kim. Challenges and opportunities in game artificial intelligence education using angry birds. IEEE Access, 3:793-804. Citado na pág. 42, 44 